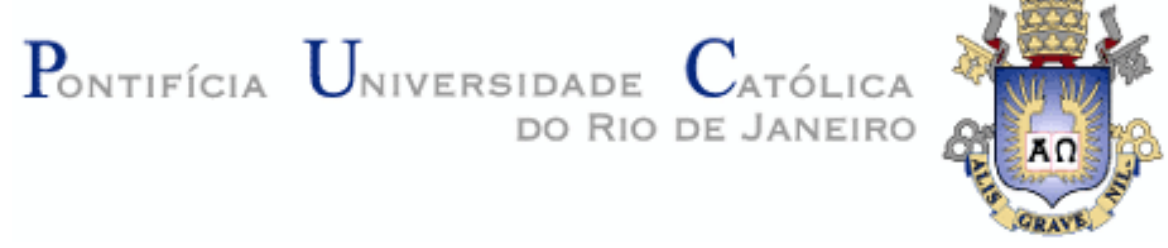

Tiago Santos de Vasconcelos

\title{
A Geografia, o currículo escolar e a ontologia: \\ possíveis caminhos para uma outra relação com o espaço
}

\section{Tese de Doutorado}

Tese apresentada como requisito parcial para obtenção do grau de Doutor em Geografia pelo programa de Pós-graduação em Geografia, do Departamento de Geografia e Meio Ambiente da PUC-Rio

Orientadora: Profa. Regina Célia de Mattos 
Tiago Santos de Vasconcelos

\section{A Geografia, o currículo escolar e a ontologia: possíveis caminhos para uma outra relação com o espaço}

Tese apresentada como requisito parcial para obtenção do grau de Doutor em Geografia pelo programa de Pós-graduação em Geografia, do Departamento de Geografia e Meio Ambiente da PUCRio. Aprovada pela Comissão Examinadora abaixo:

Profa. Regina Célia de Mattos

Orientadora

Departamento de Geografia e Meio Ambiente - PUC-Rio

Prof. ${ }^{a}$ Rejane Cristina de Araújo Rodrigues Departamento de Geografia e Meio Ambiente - PUC-Rio

Prof. ${ }^{a}$ Amélia Cristina Alves Bezerra Universidade Federal Fluminense - UFF

Prof. ${ }^{a}$ Ana Cláudia Carvalho Giordani Universidade Federal Fluminense - UFF

Prof. Luciano Ximenes Aragão Universidade do Estado do Rio de Janeiro - UERJ

Prof. Ronaldo Goulart Duarte Universidade do Estado do Rio de Janeiro - UERJ 
Todos os direitos reservados. É proibida a reprodução total ou parcial do trabalho sem autorização da universidade, do autor e da orientadora.

\title{
Tiago Santos de Vasconcelos
}

Graduou-se em Geografia pela PUC-Rio (2007). Possui Mestrado em Geografia pela PUC-Rio (2010). Professor da rede municipal de Duque de Caxias e da rede privada do Rio de Janeiro.

Ficha Catalográfica

\begin{abstract}
Vasconcelos, Tiago Santos de
A Geografia, o currículo escolar e a ontologia : possíveis caminhos para uma outra relação com o espaço / Tiago Santos de Vasconcelos ; orientadora: Regina Célia de Mattos. - 2021.

310 f. : il. color. ; $30 \mathrm{~cm}$

Tese (doutorado)-Pontifícia Universidade Católica do Rio de Janeiro, Departamento de Geografia e Meio Ambiente, 2021.

Inclui bibliografia

1. Geografia e Meio Ambiente - Teses. 2. Geografia. 3. Currículo escolar. 4. Ontologia. 5. Trabalho. I. Mattos, Regina Célia de. II. Pontifícia Universidade Católica do Rio de Janeiro. Departamento de Geografia e Meio Ambiente. III. Título.
\end{abstract}

CDD: 910 


\section{Agradecimentos}

Agradeço primeiramente a Deus, pela força, coragem e inspiração ao longo de toda trajetória.

Agradeço à minha mãe, Marlene, aos meus tios, Manoel e Elizete, ao meu pai, Antonio (ou Vilmar), e aos meus sogros, Elizabeth e Paulo, por todo apoio, carinho, cuidado e olhares compreensivos dispensados sobre todos os momentos enfrentados. São verdadeiras inspirações que me ajudaram enormemente a persistir e alcançar meus objetivos.

Agradeço profundamente minha esposa, Roberta, por toda a ajuda e amor que dedica a mim e ao nosso relacionamento. Seu apoio incondicional, sua preocupação incansável e seu senso de justiça me serviram de combustível para continuar acreditando nos propósitos desta pesquisa.

Agradeço especialmente à querida orientadora Prof ${ }^{a}$ Regina Mattos, juntamente ao grupo LABORES, e ao eterno Prof. João Rua, por construírem diversos caminhos para a compreensão e superação das diferentes estratégias de mascaramento da realidade. Não poderia deixar de agradecer também por participarem da minha (re)construção desde a graduação, ao longo das reuniões do PET, no mestrado, no doutorado, nas reuniões do LABORES, sempre ensinando que existe uma outra realidade possível e que acreditar na transformação nos faz ser quem somos.

Agradeço à Pontifícia Universidade Católica do Rio de Janeiro por todo suporte concedido ao longo desta pesquisa. Agradeço ao Departamento de Geografia e Meio Ambiente e ao Programa de Pós-Graduação em Geografia, assim como, em espacial, a todos do grupo de estudos LABORES, por todas as discussões teóricas e metodológicas e solidariedade compartilhadas ao longo destes anos.

Agradeço ao Polo Educacional Sesc, especialmente nas figuras dos professores Luiz Fernando e Edir, por toda ajuda, compreensão e solidariedade ao longo de toda esta jornada. Agradeço também a toda equipe de Ciências Humanas pelo apoio e companheirismo, bem como aos estudantes pela colaboração nos momentos finais.

O presente trabalho foi realizado com apoio da Coordenação de Aperfeiçoamento de Pessoal de Nível Superior - Brasil (CAPES) - Código de Financiamento 001. 


\section{Resumo}

Vasconcelos, Tiago Santos de; Mattos, Regina Celia de. A Geografia, o currículo escolar e a ontologia: possíveis caminhos para uma outra relação com o espaço. Rio de Janeiro, 2021. 310p. Tese de Doutorado Departamento de Geografia e Meio Ambiente, Pontifícia Universidade Católica do Rio de Janeiro.

O currículo escolar de Geografia é um tema complexo e de grande importância, não apenas para a própria Geografia, mas também para outras ciências. Dentre seus múltiplos aspectos inter-relacionados destaca-se seu aspecto ontológico, que, em nosso entender, encontra na disciplina escolar Geografia um importante contributo para a dinâmica hegemônica do modo de produção capitalista por estimular uma relação estranhada entre a sociedade e o espaço. Esta investigação é desenvolvida sob a orientação metodológica do materialismo histórico-dialético, ou seja, parte de pressupostos reais, que são os homens em seu processo de desenvolvimento real, em condições determinadas e empiricamente visíveis. Por seu turno, ao longo de sua história, o ensino de Geografia escolar pautou-se pela preocupação em consolidar o distanciamento entre o sujeito e o espaço. Em primeiro lugar, cabe discutir a tradição filosófica concernente ao desenvolvimento da ontologia, partindo desde os gregos até as formulações ontológicas marxistas. No momento seguinte, toda essa fundamentação filosófica serve de substrato teórico para a abordagem da questão curricular e realizamos uma abordagem de currículo pelo prisma marxista de Antonio Gramsci. Por fim, realizamos um estudo acerca dos principais momentos de organização e estruturação da questão curricular no país, desde o período colonial até o final do século XX. Neste sentido, a partir do século XIX concentramos nosso olhar na disciplina escolar Geografia, justamente para encontrar as raízes ontológicas que marcam esta disciplina. Assim, torna-se mister uma reorganização curricular do ensino de Geografia com vistas a permitir que o espaço seja compreendido enquanto produto da ação de transformação humana e, consequentemente, segundo o pensamento marxista, como transformação de si.

\section{Palavras-chave}

Espaço; Geografia; Currículo escolar; Ontologia. 


\section{Abstract}

Vasconcelos, Tiago Santos de; Mattos, Regina Celia de. (Advisor). Geography, the school curriculum and ontology: possible paths to another relationship with space. Rio de Janeiro, 2021. 310p. Tese de Doutorado - Departamento de Geografia e Meio Ambiente, Pontifícia Universidade Católica do Rio de Janeiro.

The Geography school curriculum is a complex and very important topic, not only for Geography itself, but also for other sciences. There are several issues that involve the school curriculum, such as politics, economics and pedagogy, which structure a document that explains conceptions and projects. Among its multiple interrelated aspects, its ontological aspect stands out, which, in our view, finds in the Geography school subject an important contribution to the hegemonic dynamics of the capitalist mode of production by stimulating an apparently strange relationship between society and space. This study is developed under the methodological guidance of dialectical materialism, it starts from real premises, which are men in their real development process, under determined and empirically visible conditions. Thus, throughout its history, the teaching of school geography was guided by the concern to consolidate the distance between the subject and space, according to the prerogatives of Cartesian philosophy. In the first place, to discuss the philosophical tradition concerning the development of ontology, starting from the Greeks to the Marxist ontological formulations. In the next moment, all this philosophical foundation serves as a theoretical substrate for the approach to the curriculum issue and we carry out a marxist approach to curriculum by philosopher Antonio Gramsci. Finally, we carried out a study about the main moments of organization and structuring of the curricular issue in the country, from the colonial period to the end of the 20th century. In this sense, from the 19th century onwards, we have focused our attention on the Geography school subject, precisely to find the ontological roots that mark this subject. Thus, it becomes necessary to reorganize the teaching of Geography in the curriculum with a view to allowing space to be understood as a product of the action of human transformation and, consequently, according to Marxist thought, as a transformation of the self.

\section{Keywords}

Space; Geography; School curriculum; Ontology. 


\section{Sumário}

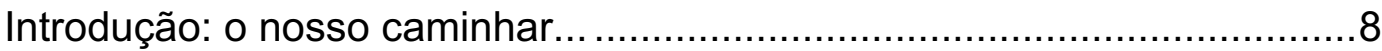

O nosso caminho científico .......................................................... 15

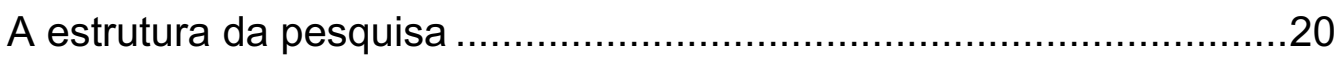

As orientações de nossa caminhada ........................................23

1. A "subjetividade cognoscente": entre conhecimento e ser...................43

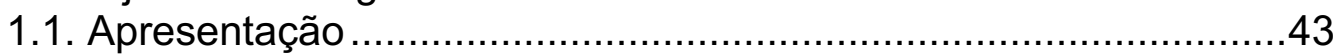

1.1.1. O início de uma discussão ontológica................................46

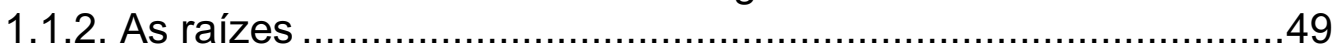

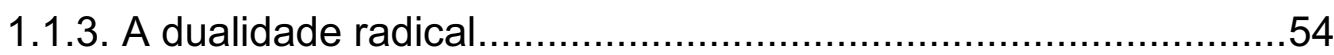

1.2. A modernidade em formação e a questão metafísica...................60

1.2.1. O racionalismo e a metafísica..................................................63

1.2.2. A ciência moderna em construção .............................................71

1.2.3. Emerge, enfim, um outro paradigma científico ........................85

1.3. A crítica ontológica de Marx......................................................91

1.4. O homem na ciência e uma aproximação com a escola .............102

2. A educação em perspectiva ontológica: trilhando caminhos .............109

2.1. A ontologia e o currículo escolar: uma discussão necessária .......111

2.2. A educação e seu papel político na sociedade capitalista..............115

2.2.1. É preciso pensar a ontologia e a ideologia em Gramsci .............131

2.3. A crítica da educação...............................................................139

2.3.1. O Currículo escolar em discussão .........................................143

3. Geografia e currículo escolar no Brasil desde uma perspectiva ontológica ................................................................................154

3.1. A Geografia clássica e Geografia moderna ...............................157

3.2. Os jesuítas e o Marquês de Pombal pensando o currículo

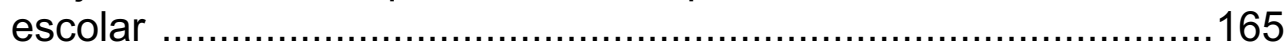

3.3. Geografia escolar no século XIX: notas de destaque ..................175

3.4. O Colégio Pedro II e a segunda metade do século XIX ................181

3.4.1. Os pareceres de Rui Barbosa .................................................188

3.5. O novo século e as transformações que não alteram...................193

3.5.1. As contribuições de Manuel Said e Delgado de Carvalho ...........200

3.5.2. O que houve com a Geografia escolar? ...................................204

3.6. Algumas considerações sobre a educação no período Varguista.212

3.7. O currículo pensado para o projeto de país liberal .......................228

3.8. De volta à marcha da ciência geográfica ..................................238

3.9. Que currículo é esse, militar? ...................................................241

3.9.1. A lei $5692 / 71$ e os estudos sociais .......................................250

3.10. A redemocratização e a Geografia crítica .................................255

3.11. Currículo de Geografia em tempos neoliberais ..........................266

4. Considerações finais ..............................................................283

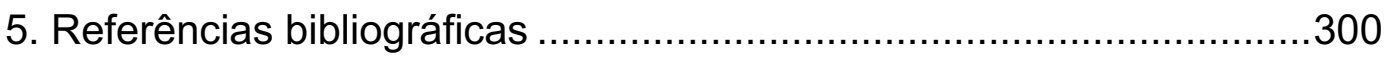




\section{Introdução: o nosso caminhar...}

Redigir uma tese de doutorado está bem distante de ser uma tarefa tranquila. $\mathrm{Na}$ verdade, o início de qualquer texto acadêmico é impreciso por, na maioria das vezes, ainda não se ter clareza de onde chegaremos nas linhas e páginas seguintes. Cientes dessa dificuldade, gostaríamos, inicialmente, de apresentar as motivações que nos trouxeram até esse momento para expor mais claramente como e por que chegamos até aqui. Nas páginas iniciais destacarei as motivações desta pesquisa, tentando entrelaçar minha experiência profissional e pessoal, e, num segundo momento, procurarei evidenciar a premência que delego a uma necessária reforma do pensamento ${ }^{1}$, posicionamento que, aliás, retornará em diferentes momentos.

O ano era 2009 e eu trabalhava num renomado colégio público da cidade do Rio de Janeiro, iniciando minha trajetória profissional como professor de Geografia. Num dia, que parecia como outro qualquer, fui indagado por outro professor de Geografia, este bem mais experiente e prestes a se aposentar: "o que você estudou na sua monografia?” Estávamos na sala dos professores num horário de intervalo aproveitando alguns minutos de descanso, quando esta pergunta, a princípio despretensiosa, chamou a atenção de mais alguns colegas, talvez esperando por uma dessas conversas que esquecemos minutos depois. A preocupação inicial era formular uma resposta que fosse curta e, simultaneamente, de fácil entendimento para a plateia que aguardava: "eu tratei das territorialidades narcotraficantes nos institutos de jovens infratores"2. Normalmente quando explicava meu tema de pesquisa na graduação, especialmente para pessoas não muito ligadas às ciências humanas, havia um período de silêncio e algum pedido de

\footnotetext{
${ }^{1}$ Ao longo do texto, para abordar as mudanças paradigmáticas científicas, farei uso da proposta de Morin (2001; 2005), acerca da marcha reformista científica que está em curso, e do pensamento de Prigogine e Stengers (1984) que assinalam enfaticamente a ocorrência de uma transformação científica, a qual denominam de metamorfose da ciência. Estes autores asseveram que a ciência de hoje - e isso já na década de 1980 - não é mais a ciência "clássica" - pautada numa racionalidade científica que torna a natureza morta e passiva. A ciência clássica produz uma concepção de mundo na direção de "obrigar a escolher entre a aceitação das conclusões alienantes que parecem impostas pela ciência e a rejeição do procedimento científico" (PRIGOGINE E STENGERS, 1984. p. 6). Com base em nossa proposta e em nosso embasamento teórico não nos furtaremos de utilizar os termos "metamorfose" ou "reforma" por entendermos que são relevantes e enriquecedores para a discussão que empreenderemos ao longo destas páginas e, também, por não serem mutuamente excludentes em suas formulações teóricas, mas complementares.

${ }^{2}$ Cabe uma explicação, mesmo que breve, destas pesquisas. Durante a graduação (Vasconcelos, 2007) e o mestrado (Vasconcelos, 2010) investiguei como se desenvolvem as tramas territoriais entre o espaço interno e espaço externo, evidenciando como esta relação transescalar é material e virtualmente constituída.
} 
maior esclarecimento. Lembro bem que naquela oportunidade a réplica de meu colega veterano veio de súbito: "Isto não é Geografia! Milton Santos acabou com a Geografia! “. Pobre Milton Santos. Susto! Este é o melhor termo para descrever minha reação ao ouvir aquelas palavras, que foram rapidamente acompanhadas por algumas risadas e de um desafio: "Vocês [se referindo de maneira genérica aos jovens professores] não sabem o que é Geografia”. E com uma folha de papel em branco na mão diz: "Coloca em ordem aqui, de norte a sul, as repúblicas bálticas”.

O "desafio" foi rabiscado na folha de papel e, de fato, eu não sabia fazê-lo. Durante muito tempo fiquei pensando na minha "incompetência localizadora" (como ser um bom professor de Geografia sem conhecer o mapa europeu?), e no quanto minha estabilidade emocional e confiança profissional foram abaladas naquele dia a ponto de recordá-la até hoje, passados mais de 10 anos. Ainda assim, recupero aquela ocasião para iniciar este estudo. Rememoro aquele dia porque entendo que foi ali que este projeto, de alguma forma, começou a nascer. O percurso para a construção deste texto foi, como de fato tem que ser, cheio de idas e vindas, movimento empírico e teórico ${ }^{3}$, espiralando entre ideias e críticas que, permanentemente, reconstruíram uma tese e $(\mathrm{m})$ antítese, entretanto cientes de que o progresso desta pesquisa não caminha na direção de uma grande certeza porque o jogo da ciência "não é o da posse e do alargamento da verdade, mas aquele em que o combate pela verdade se confunde com a luta contra o erro" (MORIN, 2005. p. 23).

O caminhar, portanto, não poderia ser realizado com plena convicção porque a única certeza era a necessidade do movimento. Caminhar, na ciência, não é uma atividade circunscrita a um curto período. Por conseguinte, o percurso que me trouxe até aqui foi iniciado muito tempo atrás, não somente por mim, mas por todos que me constituem enquanto "sujeito-pesquisador". O conhecimento não é uma revelação que se obtém num instante, como que numa marcha iniciada da ignorância, "mas uma estrada cheia de complicados meandros, que acompanha os acidentes do terreno sobre o qual ela passa e que, por vezes, deve voltar atrás" (LEFEBVRE, 1991. p. 103).

\footnotetext{
${ }^{3}$ A ideia de movimento que trazemos tem por base a filosofia dialética, na perspectiva apresentada por Lefebvre (1991), que assevera não se poder dizer melhor "que só existe dialética (análise dialética. exposição ou 'síntese') se existir movimento; e que só há movimento se existir processo histórico: história” (p. 21 grifos do autor)
} 
Retornando àquela "experiência escolar", é preciso dizer que o ocorrido naquela tarde foi, por algum tempo, inevitavelmente, um percalço traumático que me trouxe alguns questionamentos. Indagava acerca da renovação do temário geográfico e da resistência, especialmente da "velha guarda" na escola, em considerar determinados temas pertinentes ao debate teórico geográfico. Todavia, com o passar dos anos e com o acúmulo de experiências fui desenvolvendo uma outra perspectiva para aquele dia. Aquele dia somado a outros que vivenciei nas escolas por onde trabalhei desembocou numa pergunta: qual a finalidade prática de meu ofício? Ou melhor: para que(m), afinal de contas, serve o meu esforço diário? Não estava questionando meus ganhos financeiros ou meus desejos pessoais, mas os objetivos que guiavam minha prática docente. Sempre soube que não saia da cama para transmitir conhecimento mnemônicos - tal qual: As Repúblicas Bálticas são, de norte a sul, Estônia, Letônia e Lituânia, como aprendi e nunca mais esqueci - ou discutir teorias científicas que muito pouca interessam a maior parte dos estudantes. Contudo, apenas isso não era suficiente.

Submerso no cotidiano escolar, envolto nas demandas diárias e nos problemas inesperados, este incômodo ressoava e, confesso, demorei bastante tempo para tomar a iniciativa de procurar uma resposta. Não sei ao certo a razão. Talvez por desconhecer o caminho, talvez por não saber andar (ainda com receio até mesmo de engatinhar), o fato é que estava paralisado, com as pernas engessadas, naquela altura da vida, o que me trazia uma espécie de contradição, um "incômodo conforto". Do ponto onde me encontrava, confortavelmente acomodado na prática docente alienada cotidiana, vicejava uma inquietação para ir além, movimento que transformava o ponto de chegada em ponto de partida na direção de um novo desafio. Neste momento foi necessário pensar em como andar, em como movimentar as pernas para a desejada caminhada. Sair da inércia é sempre mais difícil por demandar um maior esforço inicial - Newton, em suas leis físicas, nos ensina que um corpo parado tende a permanecer parado. $\mathrm{O}$ primeiro movimento foi interno, o desejo de voltar a caminhar. O segundo, quase que simultâneo ao primeiro, foi pensar qual caminho seguir, para onde ir. Bussolado pela minha 
trajetória anterior, olhei para trás com a intenção de ir para frente, paralisado no movimento de anos anteriores, tomei como projeto futuro uma realização pretérita ${ }^{4}$.

Não seria exagero pensar que estava hipostasiado em premissas científicas que mobilizaram estudos anteriores, cujo sentido teórico não encontravam mais fundamento na minha experiência cotidiana. Faço referência às pesquisas desenvolvidas no período de graduação e mestrado, perfazendo um período em torno de oito anos, em que me dediquei à investigação das territorialidades presentes nas instituições prisionais de adultos (geridas pela Secretaria de Administração Penitenciária - SEAP-RJ) e nas de execução de medidas socioeducativas dirigidas à população não adulta imputável (administrada pelo Departamento Geral de Ações Socioducativas - DEGASE-RJ) ${ }^{5}$. Estes temas, pelos quais ainda tenho grande apego, estritamente relacionados à emergente "Geografia da violência” já não respondiam minhas dúvidas, não poderiam mais servir como estímulo para a caminhada que iniciei, tendo em vista a relação que desejava estabelecer, inicialmente, entre a escola e a Geografia escolar ${ }^{6}$.

Naquele momento prescrevia um projeto de abordagem conceitualmente restrita e de limitado alcance teórico, algo que não percebia e que ficou claro logo no início do curso de doutoramento. Como é de se imaginar, este momento foi, mais uma vez, bastante difícil por colocar em xeque minha convicção, sinalizando que meus esforços e estudos passados não teriam a tenacidade exigida para dar conta de

\footnotetext{
${ }^{4}$ Uma advertência importante faz-se necessária: há um ponto problemático específico da dialética hegeliana, que, desejamos manter certa distância. Segundo Castoriadis (2007), Hegel entende o movimento do logos transcorrendo através do "presente [que] compreende o passado (como momento 'superado') e por isso pode compreendê-lo melhor do que esse passado compreendia a si mesmo" (p. 49). Mais sintonizada com nossa proposta está a ideia de que "os resultados reais da ação histórica dos homens não são jamais, por assim dizer, aquilo que os atores haviam procurado", afastando-se de qualquer perspectiva "pré-determinada", ainda que estes resultados "que ninguém desejou como tais, possam apresentar-se como "coerentes" ou com uma "significação", parecendo “obedecer a uma lógica que não é nem sequer uma lógica 'subjetiva' [...] nem uma lógica 'objetiva', como a que acreditamos descobrir na natureza - e que podemos chamar de lógica histórica" (CASTORIADIS, 2007. p. 59).

5 A ideia inicial, em linhas gerais, do meu projeto de doutorado era demonstrar como uma valorização das "práticas violentas", enquanto manifestações políticas criminosas recorrentes na cidade, poderia enriquecer a aprendizagem de um conteúdo tão densamente trabalhado pela disciplina escolar geográfica - a cidade.

${ }^{6}$ É relevante explicitarmos que a chamada "Geografia escolar" tem uma história paralela com a "Geografia acadêmica", mas que se cruzam, se interpenetram, sem que, com isso, criem uma identidade, restringindo-se a relação de mútua legitimidade. Algumas páginas mais e daremos melhor trato à esta discussão, por ora cabe afirmar que a "Geografia escolar" é, portanto, "o conhecimento geográfico efetivamente ensinado, efetivamente veiculado, trabalhado em sala de aula", (CAVALCANTI, 2012. p. 28) cujos critérios e referenciais foram estipulados pela academia.
} 
um novo desafio. Daquele ponto de chegada não poderia imediatamente recomeçar meu trajeto. Uma nova largada demandava, de certa forma, um (novo) início renovado, reposicionado. Um reinício, portanto, simbolizava um movimento de reconsideração de qual novo ponto de chegada desejava alcançar, determinando, assim, qual percurso deveria traçar em sua direção.

Neste reposicionamento tornou-se imperioso organizar uma outra proposta de pesquisa, não inteiramente nova, mas uma proposta renovada. O percurso de pesquisa é marcado por movimentos e paralisações, começos e recomeços, chegadas e largadas, como apresentaremos melhor mais adiante. Em suma, uma permanente mobilização teórica e prática, construção e reconstrução diárias, análise e síntese inconclusas, que delimitam quando escritas no papel, ainda que materialmente apenas, nosso alcance científico. Com o fito de ampliar o escopo de pesquisa e robustecer o corpo teórico do estudo, trabalhamos na direção de uma pesquisa que aborda a relação entre a escola, ou melhor, entre o projeto escolar, a partir da disciplina escolar Geografia, e o espaço urbano em seu processo de apropriação/dominação. Esta nova proposição investigativa evidenciou, após algum tempo, o que, de fato, impulsiona esta pesquisa, a saber a constituição de sujeitos alienados.

Na sequência faremos uma discussão em torno da relação entre o projeto de escolarização e o paradigma científico em curso (e em crise), evidenciando como a já propalada reforma do pensamento urge para que possamos compreender melhor a realidade social que se manifesta na contemporaneidade. Dessa forma, afirmamos que "a ciência constitui o motor da tecnologia; a sociedade atual está fundamentada no saber científico, no saber técnico ou instrumental” (Suertegaray, 2005. p. 7), emergindo, assim, a "necessidade de aprofundar o conhecimento do conhecimento, de sabermos como se faz ciência, para que serve, para quem serve" (idem). A escola, e de forma mais ampla, o projeto de escolarização, com especial destaque à disciplina Geografia, em nosso estudo, são dimensões sociais interagentes com o mundo, com a política, com os sujeitos. Isto posto, daremos um passo à frente.

Minha vida inteira se passou dentro da escola, seja como aluno ou como professor. Estudante de escola pública numa das maiores cidades do país, na conturbada década de 1990 e no início dos anos 2000, experimentei diversos momentos que fizeram muitas pessoas se afastarem e desacreditarem do processo 
educativo. Seria bastante piegas relembrar aqui as inúmeras mazelas e frustrações que assisti naqueles anos, todavia, contraditoriamente, construí uma visão política de mundo pelas mãos de quem ali estava ou de quem gostaria de ali ter estado. Inclusão e exclusão foram situações que experimentei desde cedo ${ }^{7}$. Deixe-me explicar melhor. Por doze anos, convivendo em salas de aula com crianças e adolescentes, de diversas histórias e origens, algumas semelhantes à minha, acreditei em quem me disse que aquele espaço poderia trazer algo melhor. Estudava assuntos que não me ensinavam em casa - lá, é bem verdade, aprendia outras coisas também muito importantes. Anos depois, a universidade, intensamente vivida no início do século XXI, trouxe a maior carga de revelações e contradições pelas quais já passei, redesenhando meus projetos futuros e, principalmente, reconstruindo minha subjetividade.

Assim, a sala de aula sempre foi um espaço de descoberta, de encontros com aquilo que nunca soube, às vezes bom, às vezes nem tão bom assim. Pode parecer estranho, mas nunca vi a escola como algo negativo, como uma "prisão" ou "castigo", apesar do aspecto físico pouco convidativo. Pelo contrário, sentia prazer em aprender, mesmo quando a matemática me desafiava com incógnitas e problemas que não eram meus. Hoje vejo que no reencontro com o espaço familiar nunca estava o mesmo, havia sempre algo novo para compartilhar com aqueles que pouco frequentaram a escola, mas sabiam da sua importância. Distante de qualquer romantização da escola, que ainda será bastante explorada, discutida e criticada, é importante salientar que procuro demonstrar como entendíamos aquele espaço, quase sagrado, para a superação das limitações (econômicas, sociais e políticas) que se impunham.

Percebam que, de alguma forma, eu encarnava a escola no meu espaço familiar, reflexo de um processo que me transformava diariamente, transitando entre a experiência escolar do conhecimento e o reconhecimento da experiência escolar. A escolarização, tanto como projeto quanto processo, não se restringe ao espaço escolar, reestabelecendo-se em outras dimensões e espaços da vida. Evidente que essa percepção se deu muito tempo depois, já graduado e trabalhando,

\footnotetext{
${ }^{7}$ Uma criança pobre morando na zona sul carioca aprende rapidamente o que está ao seu alcance e o que não está. A praia, por exemplo, pode estar bem à frente, a poucos passos, mas o guarda-sol e a água de coco estão bem distantes.
} 
quando reencontrei a escola sob outra perspectiva, mas a sua capacidade de se manter como espaço da descoberta se manteve. $\mathrm{O}$ "sujeito-estudante" permanece em constante contato com a realidade circundante, estabelece canais de interconexão permanentes que permitem um permanente estado de mutação de suas estruturas cognitivas, apreendendo mensagens, códigos e conhecimentos, implícitos ou explícitos.

A passagem que realizei da cadeira de aluno para a do professor não foi planejada. A despeito da admiração que tive por alguns professores, a carreira docente nunca me pareceu muito atraente, pelas razões que todos sabemos. Nos últimos anos da graduação esta possibilidade profissional foi apresentada e, sem que percebesse, já estava abraçada de forma que hoje parece irremediável.

Após alguns anos de magistério entendo que o professor, no que tange especificamente à sua tarefa de ensinar, representa o ponto de encontro de três dimensões correlacionadas: o conhecimento científico formalizado, o conhecimento popular informal e o desconhecimento pré-estabelecido ${ }^{8}$. Em outras palavras, o professor trabalha num local limítrofe, entre o conhecimento, formalizado (e, muitas vezes, também com o não-formal), e o desconhecimento, sendo ele próprio um sujeito que experimenta esta disputa e que busca restringir ao máximo a permanência e extensão da dimensão de desconhecimento. Quando Lefebvre (1991) argumenta que "vamos da ignorância ao conhecimento" (p. 70) ele está justamente considerando nossa abrangente capacidade de conhecimento da realidade efetiva, tornando o desconhecido a condição para o avanço e revalidação do conhecimento.

Tomando emprestado, mais uma vez, uma analogia de Lefebvre (1991), podemos pensar que o conhecimento é semelhante a uma estrada, não como um percurso linear que conduz para distante do desconhecimento, mas como um trajeto

\footnotetext{
${ }^{8}$ Vygotsky (1993 apud Cavalcanti, 1998) corrobora nossa ideia quando afirma que "o aprendizado é uma das principais fontes de conceitos da criança em idade escolar, e é também uma poderosa força que direciona o seu desenvolvimento, determinando o destino de todo o seu desenvolvimento mental", significando, por conseguinte, que "o papel do ensino, sobretudo pela mediação do educador, é o de promover o 'encontro' desses dois tipos de conceitos", ou seja, "os conceitos científicos têm o papel de propiciar a formação de estruturas para a conscientização e ampliação dos conceitos cotidianos, possibilitando, assim, o desenvolvimento intelectual" (p. 27/28). Portanto, para finalizar, "o pensamento, o desenvolvimento mental, a capacidade de conhecer o mundo e de nele atuar é uma construção social que depende das relações que o homem estabelece com o meio" (p. 140).
} 
cheio de complicados meandros, ao longo de um terreno acidentado, repleto de obstáculos e que, por vezes, nos obriga a retornar. É justamente neste sentido que a escola, tanto enquanto projeto quanto como processo, não pode ser limitada somente aos estudantes ou ao espaço escolar, uma vez que todo o corpo subjetivo que a compõe é também, de alguma forma, transformado por essa "estrada do conhecimento" e reproduz esta transformação em outros espaços. Veremos isso melhor mais à frente.

\section{O nosso caminho científico}

É interessante perceber, hoje, que muitas vezes ao longo de minha vida de estudante difundi o conhecimento científico sem saber que o fazia. A escolarização tem esse difuso poder multiplicador. Tal processo inegavelmente pressupõe a difusão do conhecimento tido como científico, formalizado e, não obstante, acredito que este estudo tem como motivação ir ao encontro daquilo que Morin (2001) defende por "conhecimento" para o desenvolvimento de uma "cabeça bem-feita": "uma tradução e uma reconstrução, a partir de sinais, signos, símbolos, sob a forma de representações, idéias, teorias, discursos" (p. 24). O pensamento de Morin nos mostra, especialmente, a necessidade hodierna de transgredir as normas científicas que funcionam como barreiras ou obstáculos ao conhecimento humano, um conhecimento indisciplinado, privilegiando, à sua maneira, a inexorável dimensão do movimento, da necessidade de (re)ligação, adquirindo sentido através de um "processo contínuo ao longo dos diversos níveis de ensino, em que a cultura científica e a cultura das humanidades poderiam ser mobilizadas" (p. 33). Isso significa que pensar e reconhecer a unidade dentro do diverso, o diverso dentro da unidade é um exercício que adquire bastante proeminência nas discussões científicas 9 .

\footnotetext{
${ }^{9}$ Esta discussão ganha bastante relevância com as proposições de Prigogine e Stengers (1984) que asseveram o desenvolvimento de uma metamorfose da ciência, orientada pelo chamado paradigma da complexidade. Esta transição não ocorre sem resistências, já que muitas cabeças foram e são formadas pelo modelo de especialização fechada, cuja possibilidade de um conhecimento para além da especialização parece-lhes insensata - a exemplo de meu antagonista báltico. A ciência, da forma como é mormente praticada ainda hoje, assemelha-se a mãos que tentam reter a água, mas sempre lhes escapa pelos dedos, ou seja, a ciência insiste em manuais e receituários que deixam escapar alguns aspectos e fenômenos da realidade, o movimento, a história por entre suas páginas, subsistindo na superficialidade complexa do real.
} 
O conhecimento humano, de uma perspectiva estritamente ontológica, não pode mais realizar-se, portanto, de modo linear, unívoco, isolado. Sua reestruturação ocorre em torno de uma "reforma do pensamento" para estimular a formação de "cidadãos capazes de enfrentar os problemas de sua época", freando o

Enfraquecimento democrático que suscita, em todas as áreas da política, a expansão da autoridade dos experts, especialistas de toda ordem, que restringe progressivamente a competência dos cidadãos" (MORIN, 2001. p. 103/104).

À crítica de Morin coaduno o profícuo pensamento de outro filósofo francês, Michel Serres $(2008)^{10}$, que identifica a formação de uma ciência historicamente "formatada", em que tal "formatação" unifica e padroniza o conjunto das "medidas científicas, práticas, culturais e até mesmo artísticas [...]” (p. 17), constituindo uma repetição, uma medida generalizada. Indo além, segundo o autor, o referido "formato" tem como premissa a preservação da uniformidade do mensurável, permitindo a eficácia do modelo científico padronizante/previsível, uma vez que elimina qualquer acidente, exclui o acontecimento e impede a novidade, prosperando sem inventar, imita sem inovar. Em meio a essa discussão, torna-se evidente que estamos diante de leis mais regulares do que as inventadas outrora, destinadas a organizar ou submeter os grupos humanos, compreender e dominar o planeta, salvar ou subjugar as almas, instituindo uma experiência de mundo organizada pelas tecnociências, protegida, uniforme e previsível.

É importante aqui retomar minha trajetória profissional e apresentar, com mais clareza, os fundamentos de minhas inquietações. Esta pesquisa desenvolve-se enquanto sou professor do Polo Educacional Sesc, um complexo educacional que oferece diversas atividades, dentre as quais a "escola-residência" que recebe jovens, especialmente filhos de comerciários e de população de baixa renda oriunda de todas as unidades da federação para cursarem o Ensino Médio regular, etapa final da educação básica e central em nossas investigações. Assim, ao discutirmos o atual Ensino Médio assentamos nossa pesquisa numa abordagem crítica dos currículos

\footnotetext{
${ }^{10}$ Serres (2008) traz interessante contribuição neste tema, que será mais aprofundado quando discutirmos propriamente o método dialético, mas que já nos traz uma aproximação daquilo que esperamos conseguir demonstrar. Assim para o referido autor, na realidade, "o conhecimento difere de tudo o que se diz a seu respeito. É aproximativo, inquieto, ignorante e ingênuo, obedece à experiência, caminha à margem do erro, sempre esperando ser provado, instável e paciente, impalpável e móvel, por vezes desorientado [...]” (p. 59).
} 
oficiais dessa etapa e implementados pelo governo brasileiro, com especial atenção à disciplina Geografia, orientando nosso olhar para a compreensão do currículo como um processo, em que se torna possível perceber a presença de ideias e práticas que adquirem sentido num contexto real.

Essa importante discussão científica ganha ainda mais magnitude quando identificamos que, ainda no final da década de 1960, outro filósofo francês, Henri Lefebvre, construindo questões de método científico nas ciências humanas, já afirmara que o próprio conhecimento científico tem uma história, tem uma trajetória que não pode ser esquecida nem sacralizada em seus resultados. Toda verdade científica é relativa, está sujeita a transformações, a ser superada por novas leis ou teorias mais adequadas. Ciente de que a ciência também é um produto histórico, que avança e retrocede, que se rompe e se recompõe, Lefebvre (1991) consegue iluminar a proposta que defendemos ao afirmar que

Ciência não é uma coleção ou uma soma de resultados mortos, mas um conjunto vivo, um movimento total, um organismo que conserva em si, depois de renová-lo, todo o passado. A ciência feita não se separa da ciência que se está fazendo. A ciência adquirida posteriormente implica, verifica, completa a ciência anterior, situa-a em sua verdade. (p. 99)

É interessante notar que a reflexão de Lefebvre, em nosso entender, encontra bastante ressonância nas aulas de Geografia. Restrito ao que já estava dado, ao visível, a "uma soma de resultados mortos", o pensar sobre o espaço cindia seu movimento de renovação, distanciava-se de sua realidade empírica. Discutir a vida que anima o espaço com jovens que já o experimentaram de diferentes maneiras, como é o nosso caso, precisa ser também um momento, conforme nos ensinam Prigogine e Stengers (1984), em que "não são mais as situações estáveis e as permanências que nos interessam antes de tudo, mas as evoluções, as crises e as instabilidades", isto é, "não queremos estudar apenas o que permanece, mas também o que se transforma" (p. 5). É também fundamental perceber que esta discussão guarda importante vinculação com os sujeitos cognoscentes, ou seja, a cada aula se tornava mais claro que aqueles sujeitos reproduziam uma relação estranhada com o espaço.

Estes sujeitos, mormente passivos e disciplinados, parecem negligenciados de uma maior pesquisa, que, por sua vez, notadamente, prioriza os modos de 
operação ou esquemas de ação das estruturas sociais dominantes e obscurecem o fato de que cada sujeito é, de fato, seu autor e veículo e lugar de uma pluralidade de determinações incoerentes e contraditórias (DE CERTEAU, 1998). A reflexão sobre os sujeitos que produzem, consomem, dominam e se apropriam do espaço impele a consideração de que o espaço inclui essa conexão materialística de um homem com o outro, conexão sempre renovada (MARX \& ENGELS, 1984) por novas formas e conteúdos no decurso da marcha da história. É nessa dimensão analítica, em que sujeitos se misturam e compartilham simultaneamente diferentes fragmentos de um momento vivo e de um lugar em movimento, que percebemos o cotidiano.

O estudo do plano da vida cotidiana contemporânea é inseparável, especialmente em nossa pesquisa, do embate dialético no espaço entre valor de uso e valor de troca, indicando a predominância de um tempo cada vez mais econômico, do trabalho, afastado do tempo humano e social. Essa realidade implica a imposição da concepção mercantil de valor em diversas dimensões da vida cotidiana, inclusive do próprio sujeito que enfrenta suas próprias forças como mercadorias alienadas, ou seja, aos sujeitos não é importante sua realização pessoal ao empregá-las, mas o sucesso em vendê-las. A vida cotidiana, portanto, é encarada como o espaço projetado (pelo Estado e pela produção capitalista) para a produção de sujeitos dóceis e vorazes, produtivamente eficientes e alienados de si.

Ao contrário do que se possa imaginar, a exploração do cotidiano em nossa pesquisa não está voltada para o estudo do repetitivo, como o cotidiano revela em sua superficialidade, isto é, não nos propomos ao estudo dos gestos mecânicos e de movimentos idênticos diários que compõem as horas, dias e semanas, repetições lineares e cíclicas, tempo da racionalidade (LEFEBVRE, 1991), mas da dimensão espacial do cotidiano compartilhada na vida comum, entre os diferentes sujeitos, garantindo a espontaneidade e a criatividade como condições de uma possível outra práxis espacial. De fato, é em meio e sob aquela aparente repetição estéril, onde a disciplina escolar Geografia está calcada, que entendemos existir as possibilidades de se pensar uma outra espacialidade a partir das diversas trajetórias, desejos, imaginações que não se efetivam em práticas porque submergem ao longo das relações sociais de poder dominantes. 
Frigotto (2014) já alertara para a atual crise dos referenciais teóricos face às mudanças bruscas, sem precedentes, das relações sociais capitalistas de fim de século, em virtude da sua incapacidade de "apreender a materialidade das mediações e determinações constitutivas das relações sociais no interior de uma nova sociabilidade do capital" (p. 31). Neste sentido, não é segredo que os interesses econômicos, capitalistas, inclusive do Estado, desempenham forte influência no desenvolvimento científico, sem, contudo, serem guiados pelo espírito científico, mas pela razão do capital.

Refletir em torno da ciência clássica, que bem podemos chamar de "ciência burguesa", dedicando especial centralidade à disciplina escolar Geografia e seu currículo, e perscrutando um possível viés de inter-relação teórica e empírica entre o processo de reprodução do modo de produção capitalista e a formação ontológica de sujeitos cognoscentes é, sem dúvida, a maior motivação para os passos dados ao longo do percurso científico que nos propusemos a desenvolver. Causa profunda inquietação saber que a ciência burguesa, inegavelmente, compreende as diversas questões concretas do espaço,

Como o da desigualdade nos diferentes âmbitos humano-sociais, que é inerente à forma social capitalista, como uma mera disfunção e acaba sempre atacando, de forma focalizada, as consequências, e não as determinações (FRIGOTTO, 2014. p. $34)$.

A ciência, conforme temos tentado demonstrar, limita-se a trabalhar com a produção de um conhecimento reconhecido como verdadeiro pela explicitação de seu método e pelo rigor de sua aplicação, abrindo mão de iluminar as novas formas do ser humano se relacionar com o mundo. Esta pesquisa, pode-se afirmar, é alimentada pela certeza de um necessário repensar da disciplina escolar Geografia, na direção da revelação do mundo fenomênico imediatamente perceptível ${ }^{11}$, permitindo a superação dos posicionamentos mistificadores burgueses, assim como a compreensão dos condicionantes ou determinações que promovem

\footnotetext{
${ }^{11}$ Morin (2005) ao criticar os princípios de explicação clássicos científicos nos ensina, em estreita vinculação com os princípios aqui defendidos, que "os princípios ocultos da redução-disjuncão que esclareceram a investigação na ciência clássica são os mesmos que nos tornam cegos para a natureza ao mesmo tempo social e política da ciência, para a natureza ao mesmo tempo física, biológica, cultural, social, histórica de tudo o que é humano. Foram eles que estabeleceram e são eles que mantêm a grande disjunção natureza-cultura, objeto-sujeito. São eles que, em toda parte, não vêem mais do que aparências ingênuas na realidade complexa dos nossos seres, das nossas vidas, do nosso universo" (p. 30/31 grifos nossos).
} 
transformações na forma social assumida hoje pelo capital. Entendemos que essa premissa investigativa encontra lastro quando, conforme demonstraremos mais à frente, o desenrolar científico consagrou um modelo dual para a compreensão da realidade, cindindo em lados opostos sujeito e objeto, homem e mundo. Essa separação também é observada entre o ser e conhecimento, ontologia e gnosiologia, delimitando um conhecimento científico atrelado à dimensão dos fenômenos e distanciado dos sujeitos. Lefebvre (1991) é complementar à nossa proposta quando escreve que:

Nenhum pensamento, nenhuma ideia, nenhuma 'reflexão' que tenham objeto e conteúdo podem ser completamente neutros. Nem mesmo as matemáticas! Elas não são neutras quando estão a serviço, quando entram na prática social, quando se prestam a uma pedagogia que se dirige a determinadas pessoas e não a outras, etc. Todo pensamento tem um conteúdo, um objeto. Ao mesmo tempo, é uma vontade, uma escola. Existe alguma proposição que não implique responsabilidade? Não existe. Quem pensa inocentemente? Ninguém. (p. 30)

\section{A estrutura da pesquisa}

Após relatar brevemente a trajetória profissional e as motivações que trazem ânimo para esta empreitada científica, apresentamos, partindo para uma etapa de cunho estrutural, a problemática que nos instiga, nossa hipótese, a questão central, o objeto e os objetivos que nos norteiam, como também a base teóricometodológica e os procedimentos operacionais, itens básicos para melhor organizar o entendimento ${ }^{12}$ desta pesquisa.

Nossa problemática, por conseguinte, consiste na relação ontologicamente estranhada dos "sujeitos cognoscentes" com o espaço, fruto, em alguma medida, do currículo escolar de Geografia, que consolida a separação homem-natureza,

\footnotetext{
${ }^{12}$ Consideramos importante, especialmente por estarmos apresentando nossa estratégia teóricometodológica, elucidar que o termo "entendimento", que, de acordo com Lefebvre (1991), está inexoravelmente vinculado ao pensamento, bem como a "razão", ambas compondo o mesmo poder humano, a mesma atividade intelectual e científica. Neste contexto, o simples "entendimento", está mais associado ao analisar, ao dissecar, isto é, ao "determina[r] o detalhe, o elemento, destruindo (negando) o todo e o conjunto, dissolvendo esse todo"; por outro lado, a razão (a racionalidade) nega as determinações do entendimento; critica-as" (p. 104). Em suma, é imprescindível que "tomemos consciência do poder negativo que é inerente ao pensamento e que constitui seu primeiro aspecto: o entendimento destrói e nega as coisas e os seres dados; a razão nega essa negação e restabelece o real, o positivo" (p. 104).
} 
impedindo que se compreendam como produtores e produtos do espaço. Refletir sobre ontologia em uma pesquisa geográfica envolve pensar a relação entre espaço e existência, delimitando como uma questão sensível a forma de olhar o homem no mundo pela via do espaço. Assim, em nosso entender, uma melhor compreensão ontológica dos sujeitos cognoscentes revela uma lacuna a ser preenchida no entendimento não apenas do espaço escolar, mas também, considerando os processos político-ideológicos efetivados pelas disciplinas escolares, destacadamente no ensino médio, permite uma ampliação do cabedal de conhecimento sobre as estratégias capitalistas de produção do espaço.

A condução de uma pesquisa científica impõe a colocação de uma questão central que ilumine as investigações desenvolvidas. Em nosso caso, a luz é advinda do seguinte questionamento: de que forma o currículo escolar de Geografia interfere na produção da relação dos sujeitos cognoscentes com o espaço? A questão posta alimenta nossa tese: $O$ currículo escolar de Geografia participa da constituição ontológica dos sujeitos cognoscentes, interferindo, em alguma medida, na relação sociedade-espaço.

Guiados por estas premissas investigativas e progredindo em nosso texto, ressaltamos que o objeto não é estudado como algo estático ou localmente delimitado, mas como um processo, o que implica, inexoravelmente, em movimento, em permanências e intermitências, tanto na escala temporal, quanto espacial. Neste sentido, não concebemos nosso objeto apartado do tempo, como se pudéssemos extraí-lo da marcha da história e colocá-lo num tubo de ensaio, nem desprendido das relações socioespaciais presentes em sua realização. É justamente enquanto processo que podemos situá-lo entre duas realidades, ou seja, sua capacidade de movimento permite constituir-se como relação. Portanto, nosso objeto consiste na relação estabelecida entre o currículo escolar de Geografia e o processo de constituição ontológica dos sujeitos cognoscentes, conduzindo ao objetivo central deste estudo: discutir de que forma o currículo escolar de Geografia colabora para a produção de uma relação estranhada dos sujeitos cognoscentes do ensino médio com o espaço, descortinando um outro horizonte para esta disciplina escolar.

Com nosso objetivo principal exposto, cumpre apontar os objetivos específicos, pensados com o fito de agregar densidade teórica à investigação. 
Inicialmente entendemos ser importante contextualizar e delimitar a questão ontológica no seio da ciência. Nesse sentido, definimos, num primeiro momento, a necessidade de estabelecer nossos fundamentos ontológicos, destacando teorias consideradas centrais para embasar nossa perspectiva de abordagem dos sujeitos cognoscentes. O alcance desse primeiro objetivo é primordial para o desenvolvimento do restante da pesquisa porquanto definirá nosso compromisso ontológico pautado pela denúncia de uma gênese espacial moderna baseada na separação ocultada entre corpo e homem. Dessa forma, torna-se possível, num segundo momento, pesquisar, a partir de uma perspectiva ontológica inspirada na crítica de Marx, a relação do sujeito cognoscente moderno com o projeto curricular de Estado burguês em meio ao intenso desenvolvimento do modo de produção capitalista ocorrido a partir do início do século XIX. Com base nos dois capítulos precedentes acreditamos ter discutido adequadamente o funcionamento intrínseco do modo de produção capitalista e do projeto escolar de Estado burguês na condução das subjetividades cognoscentes modernas, que mantém suas estruturas aperfeiçoadas nos projetos escolares hodiernos, tornando fundamental aproximarmos essa discussão da realidade escolar geográfica. Assim, por conseguinte, torna-se premente, num terceiro momento, estudar, a partir de momentos considerados fundamentais, a organização do currículo brasileiro, atribuindo maior destaque ao currículo escolar de Geografia para o ensino médio, enfocando os conteúdos e estratégias envolvidos numa relação estranhada dos sujeitos com o espaço.

Relevante para qualquer estudo científico é a delimitação do método de pesquisa e a adoção de determinados procedimentos operacionais. Nesse sentido, é importante afirmar que os referidos procedimentos estão relacionados às permanentes leituras de bibliografias teóricas referentes ao temário de pesquisa. Esta investigação constitui-se como um estudo teórico, disposto a enveredar pelos fundamentos basilares do processo de constituição ontológica dos sujeitos cognoscentes, concentrando seus esforços na etapa final da educação básica, ou seja, o ensino médio. Nesse sentido, o método adotado impossibilita a realização de uma pesquisa apenas pelo viés teórico, colocando como condição sine qua non a observação mais próxima do concreto para reexperimentar o ponto de partida. Mais 
à frente, ao tratarmos com maior profundidade sobre nosso método, discutiremos melhor a importância da realização de investigação empírica.

Ponto relevante a ser destacado é a prioridade conferida ao ensino médio em detrimento das demais etapas do processo de escolarização. Nossa proposta operacional está assentada na lei 9394/96, a Lei de Diretrizes e Bases da Educação Nacional, que entende o Ensino Médio como a etapa final da educação básica obrigatória, tendo como finalidade, entre outros objetivos, a "consolidação e o aprofundamento dos conhecimentos adquiridos no ensino fundamental, possibilitando o prosseguimento de estudos", e "o aprimoramento do educando como pessoa humana, incluindo a formação ética e o desenvolvimento da autonomia intelectual e do pensamento" ${ }^{13}$. Neste contexto, optamos, na última etapa de nossa investigação, por investigar os principais documentos oficiais do ensino médio nacional, como as Diretrizes Curriculares Nacionais (DCNs), os Parâmetros Curriculares Nacionais de Geografia (PCNs) e as Orientações Curriculares para o Ensino Médio. Assim, trabalharemos com jovens que vivenciaram a educação básica por pelo menos 12 anos (considerando duração mínima do ensino fundamental e dos dois primeiros anos do ensino médio) e que estão passando por um período de transição entre o mundo do trabalho e o prosseguimento dos estudos. Este último fato torna-se bastante ilustrativo da recente importância adquirida pelo ensino médio no seio da expansão da chamada "sociedade do conhecimento", em que exatamente o conhecimento figura com destaque nas novas formas de organização social e econômica, conferindo a esta etapa escolar centralidade no acesso, discussão e reprodução desta vasta amplitude de informações.

\section{As orientações de nossa caminhada}

A partir deste momento nossa dedicação estará voltada para uma melhor explicitação de como tentaremos alcançar os objetivos propostos, esclarecendo nossos fundamentos teórico-metodológicos. Inicialmente é fundamental explicitarmos nossa concepção de espaço, conceito central na ciência geográfica e condutor de todo o percurso investigativo que desenvolvimentos.

${ }^{13}$ É importante salientar, de acordo com nossa proposta de pesquisa e muito em função da complexidade operacional e metodológica, que não trabalharemos nem com estudantes de ensino profissional técnico nem com a modalidade de ensino para jovens e adultos (EJA). 
Coerente com toda a proposta já apresentada, defendemos ser indispensável entender o espaço como um produto de inter-relações, como a esfera da possibilidade de existência da multiplicidade e, ainda, como sempre em processo, nunca como um sistema fechado. Destarte, partimos da ideia de pensamento do espaço como "um espaço de resultados imprevisíveis e de ligações ausentes" (MASSEY, 2008. p. 32), estimulando a premissa de que o espaço é vivo e desafiador.

Desse modo, o espaço deve ser aberto, tal qual o tempo já o é, nos impelindo a conceituar o espaço "como aberto, múltiplo e relacional, não acabado e sempre em devir" (MASSEY, 2008. p. 95) abrindo caminho para a possibilidade da política, ou seja, carregando em seu interior a oportunidade de os sujeitos realmente serem no espaço. O espaço é social e, como tal, se constitui como uma realidade prática, que incessantemente produz objetos, bens, símbolos, isto é, o "espaço é produto e expressão prática daquilo que a civilização, ao longo do processo histórico, foi capaz de criar" (CARLOS, 2015. p. 38). Indo um pouco mais além, o espaço deve ser estudado de modo a privilegiar a articulação de noções e conceitos com a prática social, pensando a dimensão do homem em seu processo de humanização. Portanto, a análise do espaço passa a ter uma dupla determinação:
Localização das atividades, lócus de produção, mas é, também, expressão, conteúdo das relações sociais e produto social [...]. o espaço é produto social e histórico e, ao mesmo tempo, realidade imediata, passado e presente imbricados, tudo isso sem deixar de conter o futuro que emerge como condição de vivência dos conflitos. (CARLOS, 2015. p. 39 grifos nossos)

Em nossa perspectiva teórica espacial, ganha bastante centralidade a noção de produção. Nesse sentido, Marx e Engels (1984) já mostravam que os homens podem se diferenciar dos animais "tão logo começam a produzir seus modos de vida" (p. 27). Assim, o que os indivíduos são "coincide, portanto, com sua produção, tanto com o que produzem, como com o modo como produzem. O que os indivíduos são, portanto, depende das condições materiais de sua produção" (p. 28). Sabendo que a relação inicial do homem com a natureza é mediada pelo trabalho, torna-se mais nítido que vivemos num espaço produzido pela sociedade como ato e ação de produção da própria existência. 
A relação dialética sociedade-natureza, por conseguinte, nos mostra que cada elemento da relação se transforma no e pelo outro, produzindo a vida e o espaço, ou seja, a produção da vida é, consequentemente, produção do espaço, tornando-o um produto "saído da história da humanidade, reproduzindo-se ao longo do tempo histórico, e, em cada momento da história, em função das estratégias e virtualidades contidas em cada sociedade" (CARLOS, 2015. p. 41).

Lefebvre (1981) escreve acerca da importância de retomar a amplitude do conceito de "produção", que foi reduzido pela perspectiva economicista à produção de mercadorias, objetos, mas também as relações sociais são produtos que se (re)produzem no espaço a partir da relação do homem com a natureza, "processo no qual o homem se reproduz enquanto ser genérico numa natureza apropriada e [como] condição de nova produção" (CARLOS, 2015. p. 64), constituindo assim a produção do mundo humano, ou melhor, da possibilidade de compreender o processo de produção do espaço "como produto histórico, condição necessária da realização da vida material, como conteúdo da práxis", em que o sujeito "se realiza produzindo-se praticamente, numa luta frequente contra a natureza e entre forças políticas e sociais" (Idem. p. 44).

Pensar o espaço, na perspectiva teórica adotada, impõe, mais uma vez, a consideração do cotidiano, permitindo estudá-lo em relação com a totalidade, inserindo-o no contexto dos diferentes fatos da vida social num ininterrupto processo de estruturação e desestruturação, assim como estimula a busca pelo real e pela realidade, uma vez que a vida cotidiana:

Compreende o dado sensível e prático, o vivido, a subjetividade fugitiva, as emoções, os afetos, hábitos e comportamentos, e o dado abstrato, isto é, as representações e imagens que fazem parte do real cotidiano sem, no entanto, perder-se no imaginário (LEFEBVRE, 1981 apud CARVALHO, 2015. p. 21)

O espaço não pode ser pensado como um produto qualquer, assim como não é um instrumento anterior de toda produção, quando na realidade "estaria essencialmente ligado à reprodução das relações (sociais) de produção", portanto o "espaço da produção, nesse sentido amplo, implicaria e conteria em si a finalidade geral, a orientação comum a todas as atividades na sociedade neocapitalista" (LEFEBVRE, 2008. p. 48). 
É justamente por essa via teórico-metodológica que entendemos como, sob a lógica capitalista, o espaço:

Assume a condição de mercadoria como todos os produtos dessa sociedade. [...] A lógica do capital fez com que o uso (acesso necessário à realização da vida) fosse redefinido pelo valor de troca e, com isso, passasse a determinar os contornos e sentidos da apropriação do espaço, pelos membros dessa sociedade (CARLOS, 2015. p. 64).

Não é de outra forma que o "espaço inteiro torna-se o lugar dessa reprodução, aí incluídos o espaço urbano, os espaços de lazeres, os espaços ditos educativos, os da cotidianidade etc." (LEFEBVRE, 2008, p. 49 grifos nossos), o que nos coloca num período histórico marcado pela generalização da produção do espaço sob a determinação do mundo da mercadoria (CARLOS, 2015). O espaço está inserido numa lógica que transforma em mercadoria todos os elementos presentes sobre a superfície, inclusive a força de trabalho humana. Santos (2006) coaduna uma importante reflexão à nossa proposta quando afirma que o espaço é, portanto, "uno e múltiplo, por suas diversas parcelas, e através do seu uso, é um conjunto de mercadorias, cujo valor individual é função do valor que a sociedade, em um dado momento, atribui a cada pedaço de matéria [...]” (p. 104).

O espaço como produto social, portanto, relaciona-se à estrutura, definindo as determinações do modo de produção, em escala global, mas também se refere aos agentes locais e aos diversos grupos de ação. Esta realidade muitas vezes não apresenta contornos nítidos, o que nos induz a acreditar que o espaço produzido pode ocultar mais do que revelar, uma vez que não desvela o seu processo de produção imediatamente, assim como ocorre com outras mercadorias (FERREIRA, 2007). Compreender o espaço como uma construção social não sugere negar sua centralidade na materialidade do mundo, mas realça a relevância do pensamento dialético no estudo dos processos e das relações sociais para, no momento seguinte, entender os elementos, a estrutura e os sistemas organizados.

A compreensão teórica de espaço ilumina toda a trilha metodológica que sustenta nossa pesquisa. Assim, nosso método funda-se na lógica materialista histórico-dialética. Marx (1978), na Introdução aos Grundrisse, apresentando o método da economia política, já anunciava sua opção pela perspectiva materialista ao afirmar: 
Parece que o correto é começar pelo real e pelo concreto, que são a pressuposição prévia e efetiva; assim, em Economia, por exemplo, começar-se-ia pela população, que é a base e o sujeito do ato social de produção como um todo (p. 116).

Todavia, o filósofo alemão rejeita esta proposição ao demonstrar que

No entanto, graças a uma abstração mais atenta, tomamos conhecimento de que isto é falso. A população é abstração, se desprezarmos, por exemplo, as classes que a compõem. Por seu lado, estas classes são uma palavra vazia de sentido se ignorarmos os elementos em que repousam, por exemplo: o trabalho assalariado, o capital etc. O capital, por exemplo, sem o trabalho assalariado, sem o valor, sem o dinheiro, sem o preço etc., não é nada.

Inicialmente este posicionamento pode parecer um contrassenso, uma subversão radical dos conceitos de real e concreto. Porém, urge, neste momento, esclarecer as distintas concepções concernentes às categorias abstrato e concreto no pensamento dialético, em contraposição à perspectiva formal da lógica aristotélica, para sanar quaisquer dúvidas acerca do método utilizado por Marx. Aristóteles afirma em sua obra Segundos Analíticos (apud Gontijo, 2016) que "o conceito representa o abstrato, ou universal abstrato, predicado de muitos, o geral que se forma a partir da abstração do que há de diferente, seja nos indivíduos singulares, existentes, ou em conceitos particulares" (p. 211 grifos do autor). É dessa forma que a lógica formal caminha de níveis mais concretos para níveis mais gerais e abstratos por meio da eliminação de determinações particulares, ou, ao contrário, dos níveis gerais mais elevados e abstratos para os mais concretos através da adição de diferenças específicas, diferindo profundamente da proposta metodológica hegeliano-marxista. Lefebvre (1991), atento a esta operação lógica-formal, já nos alertara da necessidade de retomar tal método em seus limites,

Como lógica do entendimento, da separação (e, antes de mais nada, da separação momentânea entre a forma e conteúdo); considerando-a, por conseguinte, no limite do pensamento, com uma verdade limitada, insuficiente, abstrata, relativa, mas com uma certa verdade. (p. 134)

Nestes termos, Lefebvre (idem) é, ainda, fundamental por assinalar a postura metodológica que pretendemos empreender nesta pesquisa,

A eliminação momentânea [da determinação, do particular] não é uma supressão, mas uma negação dialética, que ainda envolve 
o que é negado; [...]. O movimento do conhecimento, portanto, compreende dois momentos intimamente opostos $\mathrm{e}$ complementares: a redução do conteúdo (abstração) e o retorno para o concreto". (p. 131 grifos do autor)

O próprio Marx nos indica uma postura investigativa em relação ao objeto, demonstrando a indissociável correspondência entre elaboração teórica e formulação metodológica. Nesse sentido, Marx (2008) afirma que suas investigações conduziram

Ao seguinte resultado: as relações jurídicas, bem como as formas do Estado, não podem ser explicadas por si mesmas, nem pela chamada evolução geral do espírito humano; essas relações têm, ao contrário, suas raízes nas condições materiais de existência, em suas totalidades, condições estas que Hegel [...] compreendia sob o nome de "sociedade civil". (p. 48)

Essa passagem ilustra de forma bastante nítida como a formulação metodológica de Marx se diferencia da proposta hegeliana ao demonstrar que as categorias não são entidades do pensamento abstrato em uma figuração ideal, mas representam a própria dinâmica da sociedade numa relação recíproca determinada histórica e socialmente.

Essa premissa metodológica torna ainda mais relevante a compreensão da conexão entre teoria e método sustentada pela realidade social. O materialismo histórico-dialético, portanto, estrutura-se através de um ser social que é ativo, que pensa e comprova seu conhecimento no exercício de sua capacidade, ou seja, a “autoconstrução humana é resultado ontológico do trabalho porque as formas subjetivas se efetivam na avaliação do conhecimento que se confirma ou não, para mudar a realidade dada" (PIMENTEL E SILVA, 2019. p. 39/40).

Em A Ideologia Alemã (1984), Marx e Engels evidenciam este caráter ontológico do método materialista histórico-dialético ao escreverem que

O primeiro pressuposto de toda história humana é naturalmente a existência de indivíduos humanos vivos. O primeiro fato a constatar é, pois, a organização corporal destes indivíduos e, por meio disto, sua relação dada com o resto da natureza. [...] Mas eles próprios [os homens] começam a se diferenciar dos animais tão logo começam a produzir seus meios de vida, passo este que é condicionado por sua organização corporal. Produzindo seus meios de vida, os homens produzem, indiretamente, sua própria vida material (p. 27) 
Nesse sentido, os autores partem de uma realidade concreta, em que os sujeitos produzem, mas precisam garantir sua sobrevivência por meio de alterações na natureza. Assim, percebemos um elemento objetivo da atividade humana, a produção de seus meios de vida para a produção de si. Ainda na mesma obra, os filósofos expõem sua oposição à filosofia alemã, afirmando que

Não se parte daquilo que os homens dizem, imaginam ou representam, e tampouco dos homens pensados, imaginados e representados para, a partir daí, chegar aos homens de carne e osso; parte-se dos homens realmente ativos e, a partir de seu processo de vida real, expõe-se também o desenvolvimento dos reflexos ideológicos e dos ecos desse processo de vida. [...] Não têm história, nem desenvolvimento; mas os homens ao desenvolverem sua produção material, transformam também, com esta sua realidade, seu pensar e os produtos do seu pensar. Não é a consciência que determina a vida, mas a vida que determina a consciência. Na primeira maneira de considerar as coisas, parte-se da consciência como do próprio indivíduo vivo; na segunda, que é a que corresponde à vida real, parte-se dos próprios indivíduos reais e vivos, e se considera a consciência unicamente como sua consciência (p. 37/38).

Portanto, a proposta metodológica apresentada parte de pressupostos reais, que são os homens em seu processo de desenvolvimento real, em condições determinadas e empiricamente visíveis, tornando a história um movimento concreto da vida em permanente processo de concretização.

Condizentes com essas premissas metodológicas, os sujeitos de nossa pesquisa, conforme melhor discutiremos em algumas páginas seguintes, são os sujeitos cognoscentes em contato com as políticas curriculares, cuja disciplina Geografia é obrigatória a todos os estudantes, que desenvolvem em sua vida cotidiana o movimento do capital em seu processo de reprodução no e do espaço. É relevante mencionarmos que o homem vive, concomitantemente, em muitos mundos, mas a imagem construída pelos esquemas formais de análise empobreceu e deformou a realidade, além do que, segundo Kosik (1969),

Cindiu-se o mundo humano ao erigir em realidade única o mundo fisicalismo, o mundo dos valores reais idealizados, da extensão, da quantidade, da mensuração, das formas geométricas, enquanto o mundo cotidiano do homem foi declarado uma ficção (p. 24).

Coadunamos a essa discussão o pensamento de Castoriadis (2007) que já revelara que "o método, no sentido filosófico, é apenas o conjunto operante das 
categorias" (p. 23), não sendo correto impor uma rígida distinção entre conteúdo e método sob o risco de cair nas ingênuas formas do idealismo transcendental. Por sua vez, concordamos com o pensamento de Lefebvre (1991), ao afirmar que não há para o conhecimento outro caminho "além daquele que parte de um tal pensamento reduzido, ou seja, de uma virtualidade do pensamento, com o objetivo de restituir e reintegrar - ao situá-lo - aquilo que foi momentaneamente afastado" (p. 11). A realização do conhecimento pela lógica dialética impede, em seu processo constitutivo, que se possa reunir um "núcleo" racional - a teoria - e um "núcleo" real - a empiria - fundindo-os numa filosofia mágica. Portanto, é necessário dispor de um pensamento finito e/ou infinito entre dois polos, que "move-se no tempo, mas se inscreve no espaço; determina nele seu trajeto, realiza um percurso e, sob esse aspecto, não pode separar-se da práxis, da 'realidade"' (p. 12).

Nossa fundamentação encontra ainda mais subsídios ao defendermos que o conhecimento, ou melhor, o movimento de revelação do real não é contemplação, ou melhor, "o homem só conhece a realidade na medida em que ele cria a realidade humana e se comporta antes de tudo como um ser prático" (KOSIK, 1969. p. 22). A proposta do filósofo tcheco pressupõe que o conhecimento humano deriva da atividade humana sobre as coisas num movimento de transformá-las em coisas para si, uma ação prática de submeter as coisas à própria práxis e, consequentemente, torna inviável a compreensão da estrutura da coisa ou a coisa em si a partir apenas da contemplação. Por outro lado, estabelece uma grande importância à práxis, cujo estudo e compreensão é a principal via de reconhecimento dos modos de apropriação do mundo pelos homens.

Nosso procedimento metodológico, portanto, busca afinar-se com a lógica concreta, que Lefebvre (1955) nos ensina ser uma lógica do conteúdo, uma vez que:

O conteúdo é feito da interação de elementos opostos, como o sujeito e o objeto", ou seja, é no exame de tais interações que consiste a dialética, uma lógica do concreto, em que "o sujeito é distinto do objeto, mas não pode ser separado dele (p. 83).

A explicitação de nosso método encontra fundamento basilar no método dialético. Hegel (1968) ensina que a existência "significa um ser determinado; sua determinação é uma determinação existente, uma qualidade" (p. 99), significando, por conseguinte, que "a existência é um ser determinado, um ser concreto; através 
do qual se abrem em seguida múltiplas determinações, diferentes relações com seus momentos” (p. 100). Este raciocínio conduziu Marx (1978) a afirmar que o:

Concreto é concreto porque é a síntese de muitas determinações, isto é, unidade do diverso. Por isso o concreto aparece no pensamento como processo da síntese, como resultado, não como ponto de partida, ainda que seja o ponto de partida efetivo e, portanto, o ponto de partida também da intuição e da representação. (p. 116)

Este cenário traz um profundo problema para a ciência relacionado ao espinhoso percurso de investigação do concreto, que, durante muito tempo, residiu, nas demonstrações mais aparentes dos fenômenos espaciais, não postulando uma real superação da aparência em direção à essência. A própria ciência, no entanto, funciona, num primeiro momento, como uma aparência fenomênica, pois o "seu entrar em cena não é ainda a ciência realizada e desenvolvida em sua verdade", substancializando um saber não-verdadeiro e devendo "libertar-se dessa aparência, e só pode fazê-lo voltando-se contra ela", pois

Sendo esse um saber que não é verdadeiro, a ciência nem pode apenas jogá-lo fora - como visão vulgar das coisas, garantindo ser ela um conhecimento totalmente diverso, para o qual aquele outro saber não é absolutamente nada - nem pode buscar nele o pressentimento de um saber melhor. Por essa asseveração, a ciência descreveria seu ser como sua força; mas o saber nãoverdadeiro apela também para o fato de que ele é, e assevera que, para ele, a ciência não é nada. Um asseverar seco vale tanto como qualquer outro (HEGEL, 1988. p. 65/66 grifos do autor).

É justamente esta constatação que nos assegura realizar um movimento teórico-metodológico em espiral real-teoria-real, analisando e recompondo um processo com o fito de apreender a totalidade, ainda que, como se sabe, não o alcancemos plenamente. Tornada imprescindível em nosso estudo, a empiria precisa ser realizada sabendo-se que o exame do real consiste "em aplicar ao que é examinado um padrão aceito, para decidir, conforme a igualdade ou desigualdade resultante, se a coisa está correta ou incorreta", não obstante, tomando a ciência como medida é preciso estar atento ao fato de que "nosso objeto é o saber fenomenal, suas determinações são também tomadas como imediatamente se apresentam; e, sem dúvida, que se apresentam como foram apreendidas" (HEGEL, 1988. p. 69). 
Portanto, em suma, estamos empenhados em realizar uma investigação do processo de concretização "que procede do todo para as partes e das partes para o todo, dos fenômenos para a essência e da essência para os fenômenos, da totalidade para as contradições e das contradições para a totalidade" (KOSIK, 1969. p. 41). Pensar nosso objeto, por conseguinte, significa ter em mente que "cada objeto percebido, observado ou elaborado pelo homem é parte do um todo, e precisamente este todo não percebido explicitamente é a luz que ilumina e revela o objeto singular, observado em sua singularidade e no seu significado" (KOSIK, 1969. p. 25). Pensar sobre esta materialidade, este concreto, permite saber que ali se concentra, portanto, meu ponto de partida e, simultaneamente, meu ponto de chegada, um todo estruturado que se desenvolve e se cria, ocupando um lugar na totalidade do próprio real. Kosik (1969), mais uma vez, endossa nossa proposição metodológica ao afirmar que o pensamento dialético "parte do pressuposto de que o conhecimento humano se processa num movimento em espiral, do qual cada início é abstrato e relativo" (p. 41).

Lefebvre (1991), por seu turno, nos encoraja a deixarmos para trás todos os traços do formalismo, a nos libertar das obscuras sutilezas da metafísica, a abandonar seus "problemas insolúveis" para, enfim, nos tornarmos modernos ao aceitar o desafio de colocar nosso pensamento em movimento porque o real está em movimento e aceitar que "se o real é contraditório, então que o pensamento seja pensamento consciente da contradição" (p. 174). Para alcançar nossos objetivos faz-se necessário investir por esse método justamente porque a razão dialética compreende o geral e o individual, um no outro e um através do outro, buscando revelar o universal concreto, ou melhor, busca-se com a razão dialética "apreende[r] o indivíduo (singular) mas na totalidade e através da totalidade", encarando o "concreto, em sua riqueza, concebido como finalidade última do pensamento; o real, concebido como o racional supremo, ou seja, como 'razão' de todo esforço humano no sentido do conhecimento" (LEFEBVRE, 1991. p. 115/116).

De posse desses pressupostos metodológicos sentimos a necessidade de avançar na apresentação do método e afirmar que a emergência da dialética hegeliano-marxista, em contraposição à lógica formal aristotélica, compreende o particular a partir de uma particularização do "universal concreto", que se 
singulariza no individuo, em detrimento de tautologias superficiais. Desse modo, e atentos ao nosso objeto, o estudo do real a partir do

Universal concreto ocorre através de sua particularização, indicando que o singular é o universal tornado concreto, não apenas em virtude de suas particularidades, mas de sua individualidade, ou seja, de suas conexões singulares com a totalidade (GONTIJO, 2016. p. 225).

Esta afirmação não deixa dúvidas acerca da necessidade de considerar o singular em meio a todo o complexo de relações em que o universal concreto está particularizado e singularizado, o que significa que o universal somente existe no singular, que resulta da particularização do universal.

Lefebvre (1955), em outra obra, corrobora nossa proposta metodológica quando afirma que o

Conhecimento deve, pois, em todos os seus domínios, partir da unidade dos dois aspectos contraditórios do universo: o fenomenal e o essencial, íntima e objetivamente misturados. A análise quebra e separa a Totalidade a qual nós devemos em seguida reencontrar. É impossível proceder de outra forma. (p. 9)

Não é de outra forma que nossa pesquisa procura não se limitar à análise, não permitindo "reduzir o complexo ao simples. Atualmente, longe de reduzir o complexo ao simples, o método científico busca, sob as aparências simples, os fenômenos do "real complexo", ou seja, "analisar uma realidade complexa e atingir seus elementos reais é o mesmo que descobrir seus momentos", significando que a "análise deve ser operada e situada no movimento, no processo criador" (LEFEBVRE, 1991. p. 119). Por conseguinte, a investigação além da realidade fenomênica deve, no plano do materialismo histórico-dialético, impulsionar o desenvolvimento de um pensamento capaz de "compreender por dentro a nova ordem mundial e o sistema de ideias que se estruturam como sua lógica cultural" (FRIGOTTO, 2014. p. 41) e, como veremos a partir do capítulo 2 especialmente, o currículo escolar é manifestação material deste sistema de ideias.

Uma pesquisa orientada pelo método materialista histórico-dialético trabalha, inicialmente, com o concreto, que é inesgotável, já as aparências ou os fenômenos, que nos apresentam o concreto, são infinitamente complexos e interessantes (LEFEBVRE, 1955). De acordo com o que foi discutido 
anteriormente é por essa trilha metodológica que entendemos que o "mundo desdobra-se pelo conhecimento: abstrato e concreto, pensamento e realidade, conceito e dado, fenômeno e essência, determinação e transformação", tornando-se inescapável a implicação mútua destes dois mundos, em que "cada um deles constitui uma Totalidade, mas os dois constituem o Universo 'porque cada um deles contém essencialmente um momento que corresponde ao outro"' (p.11, grifos do autor). Torna-se imperioso afiançar que o método adotado é "a consciência do imenso conteúdo da vida, da experiência e do pensamento" (LEFEBVRE, 1991. p. 117, grifos do autor).

Em virtude de tal posicionamento teórico-metodológico nos colocamos como desafio investigativo, no seio da filosofia dialética, transcender do mundo fenomênico, "imediatamente perceptível, ou [d]as visões mistificadoras da ideologia burguesa, e apreender as mediações e/ou as determinações que estão trazendo mudanças na forma social que hoje assume o capital"' (FRIGOTTO, 2014. p. 40). Em suma e com base nesse contexto (de reprodução do capital) apresentado por Frigotto, revela-se com maior clareza a importância do movimento realizado pela ciência ao penetrar no conteúdo através das contradições e ao

\begin{abstract}
Penetrar nos fatos, o pensamento começa assumindo pontos de vista unilaterais, que aprofunda e supera. $\mathrm{Na}$ condição de não parar, de não estancar teimosamente numa das propriedades descobertas, ele reencontra o conteúdo, o movimento, a unidade (concreta, completa) dos pontos de vista unilaterais assumidos pelo entendimento. $\mathrm{O}$ pensamento supera e nega o que há de negativo, de destrutivo, na análise; e o faz, precisamente, ao liberar o elemento positivo obtido e determinado pela análise, ao colocá-lo em seu devido lugar, em sua verdade relativa. (LEFEBVRE, 1991. p. 181)
\end{abstract}

Esta discussão metodológica coloca em evidência como a disciplina escolar Geografia, ao longo do processo de escolarização, parece trabalhar com práticas e ideias que concorrem "para o mesmo fim de compreender e construir o mundo a partir das ideias que formam dele", ou melhor, trabalham "com as coisas reais a partir das suas ideias" e, por isso, os sujeitos envolvidos tomam "a ideia pela realidade, a ideia da coisa pela coisa, confundindo a leitura com as próprias coisas" (Moreira, 2015. p. 105). A ideia que temos de alguma coisa é fruto da síntese de dois campos diferentes: o campo sensível - referente aos sentidos, como a visão, audição etc., e à percepção, como as sensações condensadas em nossa mente - e o 
campo intelectivo - onde predominam o pensamento e os conceitos -, que estão conectados pelas nossas práticas. Atrelada a esse pensamento está a necessidade de, para se conhecer a realidade humana como pretendemos, trazer para o centro do debate o interesse por essas ideias, ou melhor, pela ideologia. Aqui cabe uma menção às palavras de Lukács, filósofo que será ainda bastante consultado, ao nos ensinar que "[...] ser ideologia de modo algum constitui uma propriedade social fixa das formações espirituais, sendo, muito antes, por sua essência ontológica, uma função social e não um tipo de ser” (2013. p. 405). Destarte, tomamos a ideologia pela função social que desempenha, ou seja, enquanto veículo de conscientização e de ideação prévia da práxis social.

É fundamental realizarmos uma discussão, nessa etapa introdutória da pesquisa, ainda que não bastante profunda, em torno do conceito de "sujeito". Antes de apresentarmos nossa proposição acerca do "sujeito" é fundamental explicitar que em nossa pesquisa esse tema é precedido pela discussão ontológica, nos termos apresentados anteriormente. Por conseguinte, a breve exposição desenvolvida a seguir serve como um balizamento prévio das problematizações vindouras.

Ao pensarmos sobre esse conceito, emerge, mais uma vez, o pensamento dialético de Lefebvre $(1991)^{14}$, que confirma a sua constituição a partir de "por um lado, um infinito, uma ordem longínqua. Por outro lado, uma ordem próxima, o finito, minha finitude", aproximando nossa proposta da aceitação dessa dupla determinação ontológica: "eu não sou nada e sou a totalidade. Sou um ínfimo detalhe no mundo e sou o mundo" (LEFEBVRE, 1991. p. 23/24). O sujeito é construído dialeticamente, materialidade uno-múltipla, organizada de forma a permitir que o ser humano seja um sujeito-objeto, em outras palavras, “ele pensa, é

\footnotetext{
${ }^{14}$ Em seu sentido etimológico, a palavra sujeito está relacionada à subordinação, referindo-se a quem exerce algum tipo de atividade prática. É interessante pensar que no mundo antigo, o filósofo Heráclito entendia que o termo homem (livre) refere-se a quem pode viver no ócio, entregue à contemplação ou à ação política, relegando o trabalho físico, a sujeição à atividade prática aos escravos. A devida referência ao pensamento de Heráclito nos obriga a frisar a consagração do chamado idealismo metafísico, que colocou em evidência o papel da divisão das atividades humanas, que, em última instancia, apresentou a separação "da teoria e da prática, da alma e do corpo, do pensamento e do objeto" (LEFEBVRE, 1991. p. 77). Neste sentido, é fundamental entender que a divisão de trabalho na sociedade grega clássica "não implicava, exatamente, uma separação entre sujeito e objeto. Ela estava expressa na abstração das relações de produção em face do relativo atrelamento do trabalho prático à necessidade $\mathrm{e}$ ao valor de uso do produto do trabalho prático" (LIMA, 2014. p. 246). O homem heraclítico, nestes termos, assemelha-se ao sujeito moderno, surgido após a deposição do pensamento aristotélico-escolástico pelo pensamento renascentista e iluminista, que guarda em sua corporeidade uma "forma-conteúdo discernível expressa na noção de consciência de si, eu, ego, pessoa etc.” (p. 249).
} 
'sujeito', mas sua consciência não se separa de uma existência objetiva, seu organismo, sua atividade vital e prática. Ele age, enquanto tal, e é objeto para outros sujeitos agentes", subsistindo em sua formação, simultaneamente, a distinção e a ligação entre o "sujeito e o objeto, o pensamento e a matéria, o espírito e a natureza [...] em interação, em luta incessante no seio de sua própria unidade" (LEFEBVRE, 1991.p. 71).

Esta consideração ganha ainda mais relevância quando observamos que estes sujeitos são transfigurados em objetos da ação, ou seja, são corpos e mentes, que ao experimentarem o espaço escolar, através das diferentes disciplinas e de seus próprios códigos e normas de funcionamento, sofrem uma espécie de metamorfose singular, passando a condição de objetos, sem deixarem de ser sujeitos. Aí está posto uma condição dialética que nos é central, em contraposição ao clássico pensamento cartesiano que separou sujeito e objeto. Assim, torna-se evidente que esta condição de objeto é precária e constantemente transgredida pelos corpos que não abandonam sua condição de sujeitos, estabelecendo uma complexa relação dialética, cuja simples separação sujeito-objeto parece não ser suficiente.

A mudança paradigmática do conhecimento (científico), iniciado nas primeiras décadas do século XX, processo que já assinalamos anteriormente, provoca uma expressiva reformulação teórico-metodológica em seus pilares e, particularmente na Geografia, a consagração do paradigma da produção social do espaço, cuja estupenda projeção coloca em realce uma abertura ao estudo sujeito, por muito tempo negligenciado do plano lógico de objetivação do real, abalando as bases do pensamento cartesiano. Lima (2013) destaca que uma das expressões mais bem-acabada dessa concessão ao sujeito, no plano teórico-discursivo, é a emergência de abordagens pós-estruturalistas, desconstrutivistas, pós-colonialistas e culturalistas, surgidas a reboque do recuo dos grandes sistemas de pensamento e das metanarrativas da modernidade.

Condizente a este cenário de transformação de determinados postulados científicos é a constatação da ocorrência de uma crise sistêmica, resultado, ao que tudo indica, de um aprofundamento das contradições do modo de produção capitalista, em escala mundial, permitindo o recrudescimento de outros sujeitos em meio ao atual panorama político-social. Uma observação mais atenta desta realidade evidencia o papel das pesquisas geográficas na revelação destes sujeitos 
em ação e, até então, pouco reconhecidos, como quilombolas, comunidades indígenas, movimentos campesinos, ativismos estudantis, entre outros. Da mesma forma, entendemos que os sujeitos cognoscentes também carecem de maior atenção pela pesquisa geográfica, muito dedicada às questões estritamente espaciais, curriculares e políticas quando investiga os espaços escolares. Assim, não se trata de asseverar a presença ou a ausência do sujeito no discurso geográfico, mas de considerá-lo um agente criativo, produtor e transformador do espaço tendo por base o paradigma da produção social do espaço e por método o materialismo históricodialético.

É de fundamental importância advertir nosso relativo distanciamento do método fenomenológico no estudo dos sujeitos. Há no curso do desenvolvimento da ciência geográfica uma crítica comum que une as diferentes correntes metodológicas: a insuficiência do modelo científico moderno instituído pela Geografia tradicional. Todavia é também importante registrar que de uma perspectiva materialista a compreensão do espaço é vista como um produto concreto de um processo histórico, possuindo uma dimensão física e real, enquanto o olhar idealista associa o espaço a uma construção simbólica de signos e ideias. Claro está nosso alinhamento ao primeiro caso, ainda que estejamos lidando com a questão do ser, da subjetividade, sua abordagem é desenvolvida de acordo com a crítica à falsa ideia de que o homem é essencialmente racional, desconsiderando contextos históricos particulares inscritos no interior das classes sociais, o que estimula a adoção de uma noção abstrata, sem correspondência com o real. Neste sentido, optamos por partir de uma realidade material para construir um percurso explicativo que, de algum modo, coloque a ciência em favor de uma possível desconstrução ontológica alienada.

Entendemos a questão ontológica em estreita vinculação com o ato humano de produção, mas não apenas restrito à reprodução física da vida, mas também é considerada como uma maneira de exteriorização de seu ser, revelando como os homens são em diferentes sentidos. Então o que os homens são corresponde com sua própria produção, o que nos direciona a pensar a forma como estes homens são ensinados a produzir e o local onde são reproduzidas estas orientações. Outrossim, estamos lidando com o ser social que é ensinado a intervir na natureza construindo objetivamente aquilo que existia apenas em sua consciência, bem como analisamos 
um ser socio-histórico, desenvolvido ao longo da história, a partir da produção material e imaterial da vida. Neste sentido, concordamos com Bomfim (2015) quando afirma que

Para Marx, o ser humano tem uma essência que não é dada a priori pela Natureza, pois ele é um ser que se faz, que sóciohistoricamente se cria. Mas à revelia da vontade e do agir humano, a Natureza determina as possibilidades da ontologia dessa espécie ao dar a constituição física/biológica dos indivíduos. [...] (p. 109 apud SOUZA \& BOMFIM, 2020. p. 57).

É assim que nos afastamos de qualquer hermenêutica preocupada em resgatar a inteligibilidade de fatos espaciais a partir de seus contextos próprios, como também não estamos dispostos a determinar o triunfo do espírito sobre a razão, notadamente das ideias humanistas sobre o racionalismo, tendo em vista o ocorrido no período moderno (GOMES, 1996). Todavia, também relutamos em desenvolver nossa pesquisa de acordo com uma visão extremada do materialismo, como num marxismo ortodoxo. Assim, buscando superar também essa dualidade, entendemos ser possível atender a uma perspectiva superadora da dicotomia materialismo-idealismo, desdobrada na profunda cisão sujeito-objeto, promovendo, simultaneamente, uma leitura ontológica do espaço e do homem. A ontologia do homem também é, ou deveria ser, do espaço porquanto a partir ação humana a realidade não é mais a mesma, o espaço foi transformado, e o homem também não é mais o mesmo porque também se transformou nesse processo.

Nesse sentido, o "sujeito" erigido em nossa proposta é o moderno, "produto da dissolução do sentido coletivo do arquetípico herdado de gêneros de vida de regime comunitário, que tinham como finalidade básica a reprodução material do homem e da comunidade" (LIMA, 2014. p. 251), quando nos modos de produção anteriores o "sujeito não passa de uma 'coisa', um conteúdo informe da existência, quando muito, um indivíduo subordinado e inominável” (p. 252). Por conseguinte, o sujeito, da maneira que o consideramos, foi gestado ao longo do processo de acumulação primitiva, período em que "na sociedade capitalista, a produção se converte em finalidade do homem e acumulação de riqueza na finalidade da produção" (p. 253). Esta abordagem ao considerar o sujeito produtor do objeto geográfico induz a compreensão da Geografia não somente como um campo científico, "mas principalmente como uma experiência que nos coloca diante do ser 
social" (LIMA, 2013. p. 20). Mais do que isso, esse "sujeito" é produto do eurocentrismo e do tecnocientismo, reelaborado em meio à expansão em escala mundial da opressão e da dominação capitalista, e reconhecido em novos outros sujeitos observados na trama histórica-geográfica atual.

Estamos, portanto, lidando com o sujeito pensante, ou melhor, com o sujeito da experiência, presente na realidade espacial e agente do processo históricogeográfico graças a sua corporeidade, cuja compreensão demanda uma investigação ontológica. Conforme mostraremos mais a frente, a questão que antecede e vincula o estudo deste "sujeito" é a relação sujeito-objeto presente na teoria do conhecimento voltada para a compreensão do movimento da totalidade concreta.

Lefebvre (1991) enriquece essa discussão ao estudar a questão do sujeito, aquele que desenvolve suas ideias em contato com o mundo, evidenciando que a relação entre o "eu" e o "mundo" "não pode ser concebida no estranho e no alheio, sem o outro e o outrem, o próximo e o longínquo, que são mesmos (dois aspectos da mesma relação)", ou, com mais profundidade, “o 'mundo' chega a esse 'eu', que sou eu, por dois caminhos: a história inteira, o passado, o tempo biológico e social - e a biografia individual, o tempo singular" (p. 23). O grande desafio parece ser o de conseguir conjugar dialeticamente o tempo biológico e social, da história, com o tempo singular, do sujeito, em consonância com uma totalidade complexa e contraditória, que exige uma análise específica, embora religada ao movimento geral.

Portanto o sujeito é social e a sociedade não é exterior a ele, nem pelo pensamento, e é Marx, segundo Lefebvre (1955), que, de maneira proposital, “o considera historicamente, como o sentido da história, e tido somente através das contradições, das mutilações, das realidades parciais, moventes e dispersas". (p.12/13), situação metodológica que nos impele a desenvolver nossa pesquisa com a premissa de que "a história do conhecimento não pode ser relacionada à história abstrata do 'ser social', mas à história concreta da prática social" (LEFEBVRE, 1991. p. 75). Afirmamos, sustentado pelo mesmo pensador (p. 88) que,

Se a história implica uma estrutura; se na sociedade, como no pensamento, as interações de elementos opostos constituem a estrutura dialética da história; se o desenvolvimento do homem, de seu poder sobre a natureza e de sua consciência de si, fornecenos o movimento de conjunto e o sentido concreto dessa história, 
então e simultaneamente a razão torna-se histórica e a história torna-se racional.

É investindo nesse caminho que, em suma, delimitamos nosso contexto teórico-metodológico, e recorremos ao pensamento de Castoriadis (2007), que, pensando a revolução socialista, nos lembra que o terreno teórico é limitado, tem alcance prático restrito, ou seja, não resolveremos os problemas que nos preocupam por meios teóricos, "mas sabemos, também, que não o serão sem uma elucidação das ideias" (p. 80). O marxismo, em sua inspiração originária, buscava reintegrar o teórico na prática histórica e a dialética devia reincorporar a:

Relação entre aquele que pensa e seu objeto, tornar-se a procura concreta do vínculo misterioso entre o singular e o universal na história, [...] desvendar as contradições que operam no real, ultrapassar perpetuamente o que já está dado [...]. Sua tarefa seria não a de estabelecer verdades eternas, mas de pensar o real. Esse real, o real por excelência, a história, era pensável enquanto era não racional em si ou por construção divina, mas o produto de nossa própria atividade, esta própria atividade sob a infinita variedade de suas formas. (p. 81)

Com base em todo o contexto construído nas linhas anteriores faz-se necessário apresentar a estrutura geral da pesquisa, destacando as principais discussões desenvolvidas nos próximos capítulos.

O capítulo 1 consiste na difícil delimitação das premissas prioritariamente ontológicas, mas também gnosiológicas, orientadoras de nossa jornada científica, tendo em vista a imprescindível tarefa de estipular os parâmetros subjetivos e objetivos que servem de sustentáculo teórico à análise dos sujeitos cognoscentes. Destarte, elegemos alguns pensadores como referências ao nosso estudo e realizamos um mergulho em suas obras com o fito de selecionar suas principais contribuições ao nosso estudo. Inicialmente, ganham destaque alguns dos filósofos que perceberam a necessidade de explicação do mundo por ele mesmo, ou seja, por uma racionalidade objetiva e imanente aos seus próprios elementos constitutivos. Neste contexto, a filosofia grega qualifica a ontologia como uma lógica mesma em que a verdade objetiva e inerente a todo e qualquer elemento básico, fundamental, constituinte do mundo pode ser encontrada neste próprio elemento. Algumas ideias e pensamentos de Heráclito e Platão servem como referências e orientação de nossa pesquisa, bem como alguns de seus debatedores, dentre eles Heidegger (1989; 1999; 2008) e Flaksman (2009). Num segundo momento, emerge o horizonte da 
modernidade, inspirando uma extrema racionalidade científica e uma requalificação ontológica, envolta num amplo cenário de discussão metafísica. A filosofia cartesiana e a ruptura científica proposta por Kant, tendo a reboque a crítica marxiana, podem ser considerados marcos de orientação da pesquisa e nos fornecem importantes subsídios para a abordagem dos sujeitos cognoscentes modernos que passarão a vivenciar os sistemas de ensino e o currículo escolar modernos nos moldes burgueses. Nessa empreitada são fundamentais as reflexões e proposições de Foucault (1987), Lefebvre (1981; 1991), Marx (2008, 2011), Lukács (2012, 2013) e Lima (2013).

O capítulo 2 realiza uma pesquisa acerca dos currículos escolares, ou melhor, procura estabelecer liames teóricos entre a questão ontológica e o currículo escolar, cuja finalidade é compreender como os currículos escolares auxiliam a compreensão da realidade e são utilizados com claros fins políticos ao serem reproduzidos na sociedade. Este objetivo pressupõe a preocupação de como podemos desenvolver uma análise ontológica do documento oficial que orienta a prática escolar, conduta que impele dois movimentos seguidos: num primeiro momento, definir nosso entendimento sobre currículo e indicar a perspectiva crítica que conduz nosso olhar; num segundo momento, trazer à tona parâmetros ontológicos que permitam investigar estes documentos. Neste último movimento, nossa principal sustentação teórica advém do trabalho de Gramsci, especialmente de sua proposição filosofia da práxis. Para esta importante empreitada são fundamentais os trabalhos de Sacristán (2001; 2020), Apple (2006) e Silva (2005), por abordarem a dimensão curricular em posição teórico-crítica, permitindo que pudéssemos empreender com maior segurança a análise e interpretação de Gramsci (2015, 2016), considerado fundamental para uma abordagem ontológica do currículo desde uma perspectiva marxista.

O capítulo 3 dá prosseguimento às discussões iniciadas no primeiro capítulo e ampliadas no capítulo 2 por apresentar uma análise teórica e empírica do currículo oficial de Geografia para o ensino médio. Nossa proposta tornou basilar a consideração do currículo enquanto produto histórico e, por conseguinte, desenvolvemos uma análise do currículo oficial brasileiro ao longo do tempo, desde o período jesuítico até os tempos neoliberais do final da década de 1990. É fundamental assinalar que esta análise se deu a partir de momentos considerados 
fundamentais para a organização ou reforma do currículo porquanto a trajetória histórica desta temática já foi tema de outras obras. Destarte, nosso intuito reside em buscar evidencias teóricas para demonstrar como o currículo escolar, especialmente o de Geografia, pode ser encaixado como em um quadro de referência ontológico que confere sentido e vida ao projeto escolar burguês materializado na relação dos sujeitos com o espaço. Para tanto, além das obras de Marx e Lukács já enunciadas, também utilizaremos a contribuição de Zotti (2004), Romanelli (1986) e Rocha (1996), que abordam a questão curricular a partir de um prisma histórico. 
Acredito que a maioria dos conteúdos tem uma relação direta com o nosso cotidiano e pode ser usado tanto para compreendermos o que vivemos tanto para agir/reagir em sociedade.

Resposta de estudante entrevistado

\section{A "subjetividade cognoscente": entre conhecimento e ser}

\subsection{Apresentação}

Conduzir uma pesquisa científica envolve uma série de demandas e ritos que, pouco a pouco, vão se somando e tornam a investigação bastante complexa. A construção de nosso percurso investigativo torna premente definir o direcionamento da pesquisa, após toda apresentação introdutória realizada anteriormente. Municiados de nosso objeto e objetivos, cientes da estratégia metodológica adotada e apresentados os conceitos e noções considerados estruturantes é possível avançar.

Inicialmente entendemos ser importante delimitar com maior clareza os parâmetros teóricos e conceituais deste primeiro capítulo, em meio a vasta discussão existente em torno do ser, especialmente se observarmos o atual cenário crítico ao capitalismo, ou, de forma mais precisa, a crítica à ordem social triunfante universalizada pelo capital.

Os árduos debates e disputas nos campos da saúde, da educação, do meio ambiente têm subsistido sem um pano de fundo verdadeiramente crítico capaz de alcançar resultados promissores. Nas últimas décadas prosperam discursos defensores de um "capitalismo melhor", "mais humanizado", difundindo a necessária garantia de uma saúde pública de qualidade, mas que, ao mesmo tempo, ainda não toca no consagrado mercado da saúde; da mesma forma, alguns ambientalistas e ecologistas apregoam um "capitalismo mais verde", o aprofundamento do "desenvolvimento sustentável" e das "tecnologias limpas", mas que respeitam o capital como comandante de um intenso e ininterrupto processo de acumulação. Não é diferente na esfera educacional, onde a razão principal de luta, numa perspectiva apregoada por tecnólogos, é por uma educação pública de qualidade, mas que, caso fosse alcançada, não impediria que o capitalismo 
permanecesse orientando a formação dos sujeitos e assegurando que a reprodução das relações sociais se mantivesse a mesma.

A situação que nos é apresentada sugere que se não há nada além do capitalismo, ou melhor, a ausência de algo desejável apesar do capitalismo, suficientemente atraente às pessoas, coloca em xeque todo o esforço de crítica e de contestação concernentes ao modo de produção capitalista. Motivados por essa questão e em consonância com outros pensadores, entendemos que as proposições de Marx e Engels estimulam a adoção de uma postura científica atinente à dinâmica da sociedade capitalista com o fito de revelar possibilidades concretas de transformação profunda desta ordem social, bem como dos espaços objetivos para o desenvolvimento de práticas transformadoras dos sujeitos - como os espaços escolares. Outrossim, esta crença está radicalmente fundada numa retomada da crítica ontológica formulada por Marx, cujo "apagamento" fornece ao sistema capitalista um futuro garantido por apresentar-se de acordo com sua aparência, ou seja, como a última forma de vida social, sem espaço nem tempo fora e para além do qual nada pode existir (DUAYER, 2015).

Consideramos fundamental ter em mente que toda busca pelo conhecimento tem por base uma ideia, ainda que geral, sobre a constituição do objeto que se deseja compreender. Em nosso caso não é diferente e colocar a ontologia em lugar de destaque impele uma investigação das concepções que fundam nossas ideias e as práticas decorrentes, ou seja, evidenciar o caráter nuclear da ontologia implica uma inescapável consciência de nossas ações e, simultaneamente, afasta a possibilidade de acreditar em noções irrefletidas da realidade e que nos induzem ao falso mundo das aparências. Por conseguinte, nossa opção pela ontologia tem como mote principal a busca pela verdade. Lukács (2013), acerca desta discussão, é cristalino ao afirmar que

[...] todas as representações ontológicas dos homens são amplamente influenciadas pela sociedade, não importando se o componente dominante é a vida cotidiana, a fé religiosa etc. Essas representações cumprem um papel muito influente na práxis social dos homens e com frequência se condensam num poder social [...]. (p. 71)

Lukács, considerado um dos grandes pensadores marxistas, dedicou especial atenção aos fundamentos do pensamento de Marx e formulou uma 
inestimável contribuição à reconstituição do pensamento marxiano, especialmente a partir dos escritos da Ontologia do Ser Social. Seu esforço de construção de uma ontologia no interior do marxismo estrutura uma importante corrente teórica para a explicitação do fundamento ontológico no pensamento marxista. Tal construção nos é bastante relevante porque auxilia a compreensão dos diferentes sistemas teóricos coexistentes, sustentados por ontologias próprias, atravessando um cotidiano comum. Nesse sentido, em termos empíricos, estes sistemas são equivalentes e suas diferenças não estarão dissipadas na empiria, ou seja, as controvérsias entre os sistemas precisam ser esboçadas e superadas anteriormente, naquilo onde residem as questões ontológicas. É neste ponto que gostaríamos de desenvolver nossa análise, tendo como premissa o pensamento marxista e cientes de que a deferência ao pensamento lukacsiano implica a consideração do caráter central da categoria trabalho, categoria fundante do ser social e que contém os germes de todas as outras determinações (LUKÁCS, 2013). Em função de nossos objetivos a centralidade da categoria trabalho não pode ser obnubilada e será central em nossa pesquisa em momento posterior. Neste momento, apenas à guisa de elucidação inicial acreditamos ser relevante destacar que Lukács investigou a gênese do ser social a partir da análise dos vínculos e distinções entre o ser orgânico (animal) e o ser social (homem), identificando o trabalho como a categoria a partir do qual se deve reconhecer o complexo concreto da sociabilidade como forma de ser, ou seja, o trabalho consiste na categoria fundante do ser social, é a categoria essencialmente intermediária, o vínculo material e o objetivo entre ser humano e a natureza, assinalando, como Marx, o caráter originário do trabalho (DUAYER et. al, 2012).

Destarte, reafirmamos uma imprescindível retomada da crítica ontológica que ajude a diminuir a névoa fenomênica e permita rever o farol inaugurado por Marx quando de seus estudos sobre o modus operandi do capital. A ontologia já foi extremamente debatida em diversas correntes filosóficas, estruturando diferentes interpretações teóricas e perspectivas científicas ao longo do tempo.

Dessa forma, este primeiro capítulo apresenta, em suma, três pilares conceituais inter-relacionados sob o céu da ciência moderna: a ontologia clássica a ontologia moderna - a crítica ontológica marxiana/marxista. Esta composição trina é extremamente ampla propositalmente, pois não há qualquer intenção de dar 
conta desta vastidão de conhecimento. Almejamos ter liberdade para transitar entre estes campos sem correr o risco de adentrarmos em discussões inadequadas e, assim, delinear com maior segurança a rota de nossa investigação. No primeiro pilar, elegemos alguns pensamentos e discussões de Heráclito e Platão, bem como alguns de seus debatedores, para entendermos corretamente as raízes da discussão ontológica que culminou, em meados do século XVIII, numa profunda ocultação do ser em meio à elevação da racionalidade como único caminho da ciência objetiva e a relegação do conhecimento homem à metafísica. A ontologia moderna não pode ser circunscrita em uma única e simples corrente ao longo do século XVIII, por isso alguns autores foram escolhidos como expoentes de reflexões consideradas centrais, a saber Descartes, Kant e Hegel. Ontologia cientificista, ontologia racionalista, como veremos, descortinam procedimentos e encetam métodos investigativos diferentes, mas que, no fundo, representam, contraditoriamente, um afastamento da ontologia no estudo do ser em privilégio dos entes. Por fim, procuraremos, a partir das discussões anteriores e da crítica ontológica elaborada pelo pensamento marxiano e recuperada por alguns pensadores marxistas, destacadamente Lukács, iluminar nossa discussão com os apontamentos condutores da ontologia, isto é, delineamos como premissa científica a indissociável relação presente entre conhecimento e ser, gnosiologia e ontologia, aí incluída o início da discussão curricular na escola, para o reconhecimento de uma ciência atenta ao estudo das subjetividades cognoscentes como suporte de compreensão do modo de reprodução social capitalista.

\subsubsection{O início de uma discussão ontológica}

Decerto, o desafio que se coloca em nossa trajetória investigativa é delimitar, com bastante rigor teórico, nossas esferas de análise no interior do espaço escolar. É interessante perceber que a escola é um espaço minuciosamente pesquisado pelas mais diferentes áreas do conhecimento e seria demasiado exaustivo recuperar a infindável produção científica em torno da escola ao longo do tempo. Todavia cabe mencionar que a "reflexão escolar", em Geografia, é extremamente rica, seja pelos estudos mais direcionados à seara político-curricular, seja pelas investigações tipicamente espaciais. Pensar a sala de aula como um território, discutir a escola como espaço disciplinador e/ou eminentemente político, 
revelar as proposições capitalistas presentes na organização do currículo escolar ou enxergar nas novas propostas neoliberais de educação os caminhos para uma obediência cega ao mercado são contribuições extremamente importantes do pensamento geográfico dedicado ao campo educacional.

No entanto, algo (ou alguém) ainda nos parece um pouco nebuloso. Salas de aula, currículo, formação docente figuram entre as grandes temáticas geográficas relacionadas ao espaço escolar, contudo o que sabemos sobre aqueles sujeitos que frequentam os espaços escolares, consistindo na razão, em última instância, da prática docente e que são sujeitados aos interesses político-curriculares? Estes sujeitos, múltiplos em sua essência e aparência, adquirem diferentes denominações - aluno, estudante, aprendiz, educando, discente etc. - cujo estudo de seus sentidos etimológicos fogem ao escopo deste trabalho, mas, nesse momento, o que nos parece mais interessante é, justamente, pensá-los como sujeitos.

Algumas páginas antes fizemos uma breve apresentação em torno do conceito de sujeito adotado. Sua existência prática é capaz de atrelar o tempo biológico e o social ao tempo singular, elaborado ao longo do processo de acumulação primitiva e voltado à acumulação de riqueza. Nesse sentido, é fundamental termos em mente que pensar o projeto escolar de estado burguês envolve não apenas o espaço per se, a constituição e o desenvolvimento das disciplinas escolares, o relacionamento interpessoal atravessado pelas questões políticas, culturais e sociais próprias daquela realidade ou, ainda, as questões de currículo e de didática ao longo das transformações enfrentadas pela sociedade e refletidas na dinâmica escolar. Em nosso entendimento é inescapável, em uma pesquisa geográfica, pensar os sujeitos implicados diretamente nos fenômenos geográficos concernentes ao espaço escolar, todavia, como pretendemos demonstrar, a compreensão dos sujeitos é precedida pelo estudo do ser e de sua subjetividade, realidades atreladas ao estudo do próprio conhecimento, enquanto campo de pesquisa.

Realizar uma discussão ontológica envolve entender o momento presente e o período pretérito do conhecimento científico, ou melhor, implica reconhecer o atual momento de revalorização do conhecimento pelo qual a ciência está passando e, concomitantemente, esse reconhecimento demanda entrever o momento passado 
da ciência, quando os fundamentos cartesianos eram predominantes e consagravam leis gerais e verdades universais.

No início do século XX, a física newtoniana, por exemplo, era a expressão de um conhecimento ideal, objetivo e completo pela sua capacidade de estabelecer uma equivalência matemática entre $\mathrm{o}$ passado $\mathrm{e} o$ futuro. $\mathrm{O}$ incrível desenvolvimento da física de não equilíbrio e da dinâmica dos sistemas dinâmicos instáveis associados à ideia de caos, da relatividade física - Einstein afirmava que o "tempo é ilusão" -, entre outros, impõem uma revisão do conhecimento científico sustentado pela ciência clássica amante da ordem e da estabilidade (PRIGOGINE, 2011). Ganhou bastante força, naquele momento, a certeza de que a cultura científica precisa estar em permanente estado de mobilização, favorecendo um conhecimento aberto e dinâmico em detrimento dos saberes fechados e estáticos, oferecendo razões para a ciência avançar.

Dentre as mudanças científicas paradigmáticas, a que mais nos chama atenção é o maior espaço dedicado ao sujeito, conforme já assinalamos anteriormente, no processo racional de objetivação do real, validando um pensamento lógico e científico que é objetivo (correspondente ao seu objeto) e universalmente racional.

A despeito dos avanços alcançados na consideração do sujeito nas pesquisas científicas, Lima (2013) afirma existir ainda uma lacuna referente às premissas teórico-metodológicas necessárias para compreendê-lo, visto que, na maior parte das vezes, é tomado como um ente dado que subverte ou mesmo conserva a ordem socioeconômica vigente, ficando seu estudo restrito aos aspectos identitários, postura que impede a observação de seu potencial criativo e transformador. Por conseguinte, o mesmo autor assevera que mesmo quando há algum esforço de conceituação este limita-se à dimensão positivo-fenomenal, impedindo a observação do caráter criativo e transformador do sujeito bem como o "horizonte objetivo em que o mesmo estaria enredado, já que sua apresentação, neste caso, é um correlato direto da representação positiva do objeto" (p. 17). Não é de outra forma que esta "abertura" ao sujeito, indicando a ocorrência de uma reorientação epistemológica, coloca como questão central as condições para sua compreensão na produção social, ensejando uma reavaliação do que se depreende por sujeito em Geografia. A empreitada científica em torno do sujeito exprime sua necessária 
compreensão nos diversos fenômenos geográficos, envolvido em conceituações e metodologias próprios ao seu estatuto epistemológico e não apenas como produtor do conhecimento.

Evidentemente não nos assiste apresentar o itinerário científico vivenciado pelo sujeito na Geografia em suas minúcias conceituais, mas não nos furtaremos em discutir como o desenvolvimento da ciência, especialmente a partir da chamada modernidade, desembocou em um afastamento da compreensão da dimensão ontológica das subjetividades cognoscentes, postura que entendemos persistir e promover seu sombreamento nos estudos geográfico-escolares. É também fundamental afirmar que não pretendemos, em hipótese alguma, nos aventurar numa empreitada biográfica e bibliográfica acerca de alguns pensadores escolhidos intencionalmente ao longo desta jornada, mas tão somente selecionamos algumas de suas obras e ideias que consideramos relevantes para nossa pesquisa. Isso significa estarmos atentos ao risco de amputarmos o potencial esclarecedor das obras desses autores, contudo entendemos ser ainda maior o perigo de alçar voos muito altos e padecermos na vaguidade, bem como tornaríamos nossos objetivos ainda mais difíceis com uma exaustiva recuperação de suas teorias. Dito isto, o último alerta concerne sobre a opção de determinar alguns pensadores como nossos marcos referenciais, funcionando com uma espécie de orientação temporal e conceitual, em que priorizamos, não propriamente a pessoa, o sujeito, mas algumas de suas ideias e discussões com o fito de, a partir de sua problematização, desenvolvermos nossos argumentos.

\subsubsection{As raízes}

É sabido que a ciência geográfica é tributária, em grande medida, das tradições epistemológicas cartesiana e kantiana, resultando em sortidas dicotomias persistentes, tais como entre interioridade e exterioridade, homem e espaço, sociedade e natureza, sujeito o objeto. Este último par adquire bastante relevância no seio da ciência moderna justamente por emergir em contato com a ideia de que a razão, estruturada por um método, é ela própria sujeito e o mundo é objeto de sua organização. Assim, é possível afirmar que a hegemonia da razão sustenta a base epistemológica da ciência moderna, consolidando a cisão entre o sujeito e o objeto 
do conhecimento. Esta separação é fundamental não apenas para a ciência em geral, mas, também, para a Geografia em particular, exercendo grande poder na estruturação e sistematização do conhecimento e permitindo sua posterior aceitação no rol das ciências formais. A estrutura e organização científicas modernas não são produtos apenas do seu tempo ("iluminado"), mas também registram preceitos e premissas oriundas de um período pretérito fundamental para o desenvolvimento da ciência, envolvendo procedimentos metodológicos, justificativas operacionais, objetivos prévios e pilares teórico-conceituais. É em meio a essa volumosa seara que procuraremos iniciar nossa investigação geográfica procurando realçar uma discussão ontológica ao colocar em destaque o sujeito, o vínculo corpóreo entre o objeto e ação, elo empírico que permite compreender com maior profundidade o espaço escolar a partir da devida iluminação da subjetividade cognoscente.

Carregada de contradições e de disputas epistemológicas, a questão em torno da relação do homem com o mundo é bastante antiga, registrando profundos embates concernentes à organização de um conhecimento científico suficientemente capaz de abordá-lo. Consideramos ter grande proximidade com nosso estudo, bem como de grande valia ao desenvolvimento da ciência, o pensamento de Heráclito (cerca de 540 - 470 a.C.), filósofo grego pré-socrático, que, envolto em suas ideias, manifesta desde cedo múltiplas tentativas de enunciar um princípio primeiro, original, único, da ordem vigente no universo. Veremos que essa postura vai encontrar similitudes com outros pensadores séculos depois, no entanto é interessante perceber que o chamado "filósofo de Éfeso", num dos mais famosos fragmentos recuperados de sua obra (fragmento 50), afirma que "Ouvindo não a mim, mas ao logos, é sábio ser tudo-um" (COSTA, 2002. p. 197 grifos nossos).

Em seus fragmentos ${ }^{15}$, Heráclito utiliza a terceira pessoa, nunca destacando a si próprio, mas fala em nome do ser do universo, como um porta-voz da Ordem universal, da Lei do Mundo. O logos, portanto, é manifestado através de Heráclito

\footnotetext{
${ }^{15}$ É importante esclarecer que aquilo a que chamamos de fragmentos, diferente do que a palavra parece sugerir, não são pedaços de papiros descobertos em escavações ou guardados em bibliotecas pelo mundo, mas são citações realizadas por outros escritores daquilo que supostamente teria dito o pensador em questão. A tradição histórica indica que, embora já ocorresse com Platão, o hábito de fazer referência a outros filósofos teria sido iniciado de forma sistemática por Aristóteles, que, segundo comumente se aceita, citava o pensamento de outros com o objetivo de demonstrar que as ideias precedentes seriam visões ainda não aperfeiçoadas de sua própria teoria (MARTINS, 2007).
} 
e significa um grande esforço de decifração da physis. Esse enunciado proporcionou um sem número de significações, como norma do mundo, razão, relação, lei do devir, definição, enunciado, narrativa, reunião, devir (SANTOS, 1990).

Em uma conferência realizada em 1951, intitulada Logos, Heidegger (2008) busca realizar uma interpretação do logos de Heráclito, colocando-o como relacionado à recolhimento e acolhimento, sendo integrador do real. Aqui estamos diante de um questionamento básico: o que significa o acolhimento do Logos? Em uma reflexão incipiente está clara a oposição à ideia de separação, dispersão, significando, portanto, reunião, aproximação (légein). Por conseguinte, no interior da concepção de logos está presente a ideia de deixar as coisas reunidas e aparentes a todos, ou seja, a compreensão do logos leva ao que aparece, ao que se produz e se apresenta diante de nós (SANTOS, 1990).

Logos e legein, como se vê, são vocábulos à polissêmicos. Com o intuito de esclarecer esta árida discussão filosófica realizamos um exercício de explicitação, tão característico da atividade docente, e chegamos a ideia de que ambos consistem, em suma, em dizer. Verbo que se torna, segundo este raciocínio, instaurador do mundo e que não se restringe às palavras, letras ou outros sinais, mas, sim, como modo de apresentação das possibilidades do ser nos entes ${ }^{16}$, "configurando a irrupção do horizonte significativo próprio que delimita o real”. O logos, portanto, tem seu sentido originário encoberto por uma tradição filosófica de considerá-lo como linguagem, isto é, o sentido de comunicar um enunciado ou juízo a alguém. Destarte, caberia somente à linguagem a responsabilidade de transmitir conhecimento entre os entes intramundanos, de tal modo que ela teria a função de conectar o homem ao mundo, realizando a ligação entre as palavras e as coisas (FOUCAULT, 1987), ou melhor, o encobrimento do logos foi consequência de um

\footnotetext{
${ }^{16}$ De acordo com Heidegger (1989), em termos ontológicos, o homem é o ente que a cada vez nós somos e que possui a capacidade de questionar o sentido do ser. O filósofo alemão indica, num primeiro momento, que elaborar a questão do ser significa tornar "transparente um ente - o que questiona - em seu ser", ou seja, "esse ente que cada um de nós somos e que, entre outras, possui em seu ser a possibilidade de questionar, nós o designamos com o termo pre-sença [dasein]" (p. 33). Num segundo momento, Heidegger demarca a dimensão ontológica desse ente, caracterizado como abertura para o ser através do termo alemão dasein, representando, simultaneamente, um aspecto de localização $(d a)$ e uma dimensão do ser (sein). Esse binômio conjugado sugere o estar efetivamente na realidade, portanto o dasein é "lugar" onde dá-se o ser e, ao dar-se, nesse acontecimento, desvelase a totalidade dos entes (SANTOS, 2016).
} 
expediente interpretativo que assumiu essa palavra como mero veículo de ligação entre as representações internas e a realidade exterior.

Heidegger (1989) apresenta um valioso alerta relacionada à esta tradição. Segundo o autor,

Para a consideração filosófica, o próprio $\lambda o ́$ ó [logos] é um ente e, segundo a orientação da antiga ontologia, um ente simplesmente dado. De início, as palavras e combinações de palavras em que as coisas se exprimem são simplesmente dadas, isto é, podem ser encontradas tal como as coisas. A primeira investigação da estrutura do $\lambda o ́ \gamma o \varsigma$ [logos] simplesmente dado constata o simplesmente dar-se em conjunto de várias palavras (p. 216/217 grifos do autor)

Ao caminharmos nesta direção investigativa chegamos no fragmento 50 de Heráclito que assinala, dentre outras coisas, a existência de uma ordem universal única que fala e cabe ao homem exercitar sua escuta para apreendê-la, isto é, a verdade está dada, pré-existe aos sujeitos, consistindo num código que nem todos estão preparados a decifrar. De forma ainda mais contundente, acreditamos que Heráclito prescreve três dimensões separadas, a dimensão humana, a realidade em si e o logos que a apresenta tal como ela é. Outrossim, conhecer a verdade significa recolhê-la em sua apresentação e ofertá-la em descoberto. Entendemos que Heráclito ao estipular a relação tripartite entre logos-homem-realidade, está, de fato, enaltecendo a mediação humana como necessária para o entendimento da realidade, mas evidencia que este conhecimento não nos pertence, e, por isso, não cabe desenvolvermos nossas próprias ideias sobre o mundo, mas, apenas, decodificar o $\log o s$ que nos fala.

Neste sentido, resta óbvio a orientação de Heráclito para que a posteridade ouça não a ele, mas ao logos. Heráclito nos ensina que o homem é porque escuta, ou melhor, cada homem é aquilo que é em função do "como" de seu escutar (COSTA, 2002). O filósofo defende que o homem não pode dar ouvidos ao mundo enganoso das falsas impressões, pois este ruído ensurdece o homem para a escuta do logos. Neste sentido, o conhecimento consiste, portanto, na capacidade de ouvir o logos, ouvindo-o, “o homem escutará do próprio logos a revelação de sua natureza fundamental: ser tudo-um" (COSTA, 2002. p. 224 grifos nossos). Heráclito está claramente convocando para a realização de uma escuta diferenciada, não- 
ordinária, que permita a prática da postura recolhedora. Todavia, como se dá essa escuta clamada pelo efésio?

Num primeiro momento é bastante perceptível que o logos esteja convertido em palavra, em discurso. Por conseguinte, se alguém proferir algo sobre alguma coisa é necessário ficar atento para uma escuta minuciosa. Ademais, as palavras, a linguagem, o discurso não encerram o logos, mas o compõem, fundadas em sua essência. Contraditoriamente, o logos apresenta todo o seu vigor no ocultamento, não dizendo nada através das palavras porquanto sua presença ocorre naquilo que não é dito, no que resta de silêncio. Em outros termos, experimentamos o logos em sua dimensão fenomenal, enquanto face de demonstração dos entes, contudo o sentido mais radical dessa experiência permanece oculto, recôndito.

Uma vez compreendido esse duplo aspecto do logos se torna mais nítida a ideia de que o velamento é condição de possibilidade para todo a revelação e que, não obstante, o ser que se revela no ente, simultaneamente, se retrai em recôndito. Em outros termos: o fenômeno, aquilo que aparece à presença, se dá como erupção do ser no ente, mas a própria essência do ser permanece resguardada. Auscultar o logo significa compreender a experiência originária do ser e a realização de todo o real em consonância com a ideia de que a totalidade dos entes se dá na tensão entre encobrimento e desvelamento (SANTOS, 2016). Nesta tensão entre o mostrar-se e esconder-se o ser não se doa por completo nem se recusa inteiramente, ou seja, o dar-se no retraimento, o apresentar-se na ausência, o estar na falta, é vigor próprio, a força inaugural de toda a criação (CARNEIRO LEÃO, 2010). Segundo o mesmo autor, em um tom poético,

No movimento de sua realização, a realidade é tanto o horizonte em expansão da luz de todas as singularidades como a universalidade protetora da noite, onde todos os gatos são pardos. A noite dá à luz os indivíduos para no fim do dia os recolher em seio materno. (p. 112)

A contribuição do pensamento de Heidegger para o entendimento desta dimensão da filosofia heraclítica também nos induziu a perceber a construção de uma ontologia. A pluralidade de coisas diversas entre si compõe uma unidade ontológica que abrange todos esses aparentemente distintos entes, instituindo, no pensamento de Heráclito, a totalidade da existência de forma única em nível metafísico. Congruente a esta perspectiva percebemos vários entes em nosso 
cotidiano, e embora esses entes não possam ser reduzidos aparentemente uns aos outros, conceitualmente eles pertencem, em essência, a uma unidade. Assim, a percepção de unidade por detrás daquilo que se percebe como oposto adquire grande centralidade por atribuir ao conhecimento a capacidade de se encontrar a verdade ainda não conhecida. Assim, além de uma ontologia, ganha corpo, também, uma gnosiologia.

Isto se deve ao fato de que a verdade que o mais comum dos homens parece não compreender, habituado a ver as coisas do real separadamente, é como uma única coisa que pode conter em si determinações opostas sem deixar de consistir em uma unidade perfeita. Grande parte dos homens, descrentes acerca de tudo que extrapole a experiência sensível, tende a desprezar a unidade e atém-se à multiplicidade aparente. $\mathrm{O}$ esforço teórico de Heráclito é bastante significativo no sentido de colocar o espírito humano em direção ao conhecimento do real, buscando estabelecer ligações entre a esfera humana e a divina, como também a comunicação entre o domínio visível e o invisível.

\subsubsection{A dualidade radical}

As proposições de Heráclito foram, e ainda são, bastante debatidas em diversos campos do saber e, concordando com alguns estudiosos, um dos grandes debatedores do legado heraclítico é Platão (cerca de 428 - 347 a.C), autor mais antigo a citá-lo, que, segundo esses mesmos estudiosos, demonstrou em alguns momentos de sua obra, destacadamente, em nosso caso, no diálogo Teeteto $^{17} \mathrm{e}$ Sofista ${ }^{18}$, uma filiação argumentativa à Heráclito, ainda que não se possa afirmar

\footnotetext{
${ }^{17}$ Neste diálogo, Platão mostra ter conhecido e levado a sério a teoria do fluxo universal, uma das teses mais conhecidas e atribuída a diversos pensadores, mas especialmente a Heráclito e seus seguidores. Heráclito afirmou o fluxo universal em contraste a Parmênides, que defendia uma realidade estática e fixa, tornando aquele filósofo bastante reconhecido como o pensador mobilista. Este diálogo é totalmente voltado para a pesquisa da possibilidade do conhecimento no mundo sensível. Neste contexto, Platão evita qualquer referência explícita às formas; sua preocupação é investigar se é realmente possível o conhecimento sem a garantia das ideias (SEVERO, 1992).

${ }^{18}$ Essa obra é considerada a mais completa exposição da teoria do ser platônica. Visto como um manifesto ontológico por excelência consiste em importante marco na metafísica ocidental e indica que a ontologia platônica se constitui como a afirmação positiva de uma forma superior de comunicação entre os diferentes gêneros que compõem a tessitura do real (o repouso, o movimento, o ser, o mesmo, o outro) e o discurso (AREAS, 1999).
} 
com convicção sua concordância, quando muito sua inspiração para empreender suas próprias ideias ${ }^{19}$.

De forma geral, é sabido que Platão dedicou boa parte de sua vida a discutir o conhecimento e em suas formulações estabeleceu a dualidade existente entre dois mundos: num plano existiria o mundo das formas ou das ideias, o mundo inteligível, relacionado ao conhecimento prévio, a priori, que todos trazemos na alma e que permite a identificação do objeto. Tais conhecimentos são as chamadas ideias ou formas, pertencentes ao mundo inteligível, fora do tempo e do espaço. Assim, os objetos do mundo comum organizam suas estruturas de acordo com essas ideias ou formas primordiais, mas não as revelam integralmente, consistindo apenas em imitações imperfeitas; em outro plano haveria o mundo concreto e sensivel, acessado pelos sentidos (visão, paladar, olfato etc.). A opinião que formamos das coisas a partir das sensações formaria uma "falsa consciência" que se julga correta, tornando, não obstante, esse mundo enganoso.

Em consequência, Platão utiliza a dialética, entendida como a confrontação de teses, com o objetivo de legitimar o discurso, tecer o conhecimento do mundo sensivel, preparando o conhecimento para a contemplação das essências. Assim, a contemplação, ou melhor, a percepção é tomada como a medida de todas as coisas, um mundo conhecido apenas pelo homem independente, capaz de pensar e falar. A notável ontologia platônica orienta-se, portanto, pela compreensão das complexas relações instituídas entre os produtores de discursos (na polis) e de suas concepções do mundo fenomenal. Neste sentido, Platão procura se contrapor aos sofistas, exímios dominadores da retórica persuasiva, através da ciência e de uma retórica que busca a verdade.

O conhecimento, por conseguinte, não pertence à ordem da percepção, embora nela possa ser comprovado, pois esta, quando controlada por uma técnica de raciocínio, a si mesma se ultrapassa. Essa diferença em Platão é bem apresentada por Diès (1950), ao afirmar que conhecer é perceber outra coisa que o percebido e o saber racional - que tem por objeto as ideias e essências - pertence a uma realidade que não é percebida, mas compreendida (apud SEVERO, 1992). Emerge,

\footnotetext{
${ }^{19}$ Cabe ressaltar que Platão também faz uma clara referência a Heráclito em outro diálogo, Crátilo (402a), da seguinte forma: "Heráclito diz, em algum lugar, que todas as coisas estão em movimento e nada permanece, e, comparando as coisas ao fluxo de um rio, ele diz que não se poderia entrar duas vezes no mesmo rio" (KIRK, 1993. p. 189 apud MARTINS, 2007. p. 61).
} 
assim, a ideia de anamnese, que é a consciência que percebe e se descobre como pensamento que conhece. Ao estabelecer que a anamnese é conhecimento e que esse conhecimento tende a um significado, Platão indica que é no âmbito do significado, da relação palavra-coisa, que fará sua oposição aos sofistas. Sustentado pela técnica que analisa o fato bruto, ou seja, pela dialética, procura demonstrar que existe, além do fato, algo essencial que é o que assegura o próprio mundo sensível. A linguagem passa a ser o instrumento que pavimenta o caminho para a dialética.

Por outro lado, a dialética de Platão envolve a dimensão metafísica, cuja história se desenvolve com relativa uniformidade a partir da determinação do pensamento platônico-aristotélico. Bornheim (1983) ensina que todos os metafísicos fazem do ser o objeto prioritário e fundamental de suas investigações, indicando que o pensamento metafísico está situado entre o logos e a physis de tal maneira que o logos é privilegiado em detrimento da physis. Assim, apoiado no pensamento de Heidegger ${ }^{20}$, o supracitado autor defende que

Tudo se passa como se a physis devesse ser descartada, a fim de que o logos chegasse a ser plenamente ele mesmo - e tal foi realmente o programa que se propôs explicitamente o idealismo da etapa final da metafísica: o diferente do ser deve ser integralmente absorvido pelo ser - no caso de Hegel, pelo Espírito -, porque só assim o ser pode realmente ser em toda sua soberania (p. 26).

A construção argumentativa de Bornheim sinaliza que Platão vislumbrava o conhecimento como a possibilidade de conversão do mundo sensível em ideias ou formas, libertando a alma das "aparências sensíveis", localizadas na physis, para alcançar o conhecimento das ideias verdadeiras, o pleno domínio do logos. É com base nesse raciocínio que Platão afirma que as coisas do mundo sensível nunca são, não podem ser tomados como algo que fixamente é, mas sim como algo que sempre pode vir-a-ser. Nesse sentido, a doutrina platônica ratifica que o conhecimento é derivado da percepção das coisas em movimento e este que percebe também

\footnotetext{
${ }^{20}$ Entendemos ser relevante retomar a valiosa contribuição de Heidegger ao debate ontológico que almejamos desenvolver, especialmente quando ele afirma que "toda ontologia permanece, no fundo, cega e uma distorção de seu propósito mais autêntico se, previamente, não houver esclarecido, de maneira suficiente, o sentido do ser nem tiver compreendido esse esclarecimento como sua tarefa fundamental" (1986. p. 37 grifos do autor)
} 
participa deste vir-a-ser, portanto está também sempre em mudança, não podendo perceber sempre do mesmo modo ${ }^{21}$.

Platão parece enfrentar com estas ideias as dificuldades decorrentes, de um lado, do reconhecimento de que a sensação mergulha o pensamento no múltiplo e no movente, impedindo a constituição de uma ciência (episteme) rigorosa; e, por outro lado, a necessidade de uma teoria das formas que exprimisse as relações do sensível com o inteligível. O caminho percorrido pelo filósofo leva-o ao esboço de uma "nova ontologia" frente ao incognoscível do múltiplo e ao silêncio do "tudoum",

Esta "nova ontologia" corresponde à afirmação do ser como eixo principal de problematização fillosófica e compõe o esforço de criação conceitual de um pensamento que reintegra o ser e o devir a partir da alternância das categorias ontológicas de movimento, de repouso, do mesmo e do outro, em uma única dimensão. Portanto a ontologia platônica se constitui como um projeto de estruturação sistemático e metodológico da identidade em seu jogo com a diferença, importando realçar que a sistematicidade ontológica é assimilada ao método dialético na medida em que ela se estabelece como um permanente retorno filosófico à ordem inteligível das ideias. Neste contexto, ganha corpo a ideia de que somente por intermédio de uma ontologia que comporte um princípio de relação e, por conseguinte, que não separe completamente ser e não-ser será possível estabelecer as condições básicas para nosso acesso ao real.

A menção ao pensamento dialético platônico não nos autoriza a tomá-lo em sua integralidade. As análises de Platão não estão vinculadas estritamente à "realidade", mas apenas ao seu "mundo das Ideias", o que limita a adoção do seu pensamento à esfera sugestiva, especialmente quando posicionamos o ser no centro da relação, imprescindível para o desenrolar do jogo de articulações do real. Essa sugestão nos parece importante por permitir que a problemática dialética seja experimentada no plano ontológico sem que, todavia, restringíssemos nossa análise

\footnotetext{
${ }^{21}$ Neste caso é interessante fazer uma nova menção ao diálogo Teeteto, em que Platão apresenta a conversa entre os personagens Sócrates e Teeteto sobre o argumento de Protágoras - "o homem é a medida de todas as coisas". Sócrates utiliza o exemplo do vento para mostrar que algo da objetividade (fenômeno) é exterior aqueles que sentem e lhes provoca sensações diferentes: "não há momentos em que o mesmo sopro de vento dá a um de nós um arrepio e ao outro nada; para um ele é leve, para o outro violento?" (apud SEVERO, 1992).
} 
a aquilo que Platão entende ser seu principal objetivo: a superação do mundo das aparências, feito que somente pode ser alcançado através do raciocínio. (BORNHEIM, 193). Esta constatação indica ser correto afirmar que a constituição da dialética platônica está indissociavelmente ligada à construção de sua ontologia, isto é, à relação entre os âmbitos fenomênico e numênico e à participação dos entes sensíveis nas formas inteligíveis, exigindo um pensamento dialético estritamente vinculado ao mundo das Ideias. Em suma, é possível constatar que Platão integra ao discurso ontológico a questão da alteridade entre a Ideia e o ente em geral, afirmando que a essência, o ser do ente, encontra-se na Ideia, ou seja, a Ideia é um ente metafísico que encerra o ser das coisas em geral (MARTINS, 2007).

Não é de outra forma que a dialética platônica estimula o abandono do sensível em favor da ideia, movimento racional que permite ao filósofo dirigir seu olhar para o verdadeiro, propiciando-lhe superar a esfera das aparências, do meramente verossímil (RACHID, 2008). Bornheim (1983) ensina que a dialética platônica é toda baseada no binômio separação-unidade, consistindo na arte de aquilatar o saber, de interpretar a raiz da separação, de entender como o separado se comporta, contudo, a dialética não é apenas uma "ciência fria, um processo puramente lógico, que se limita a constatar o fato da separação; ela não pretende apenas compreender: quer resolver, tende a algo, persegue um fim [...]" (p. 42). Por conseguinte, Platão coloca a dialética como uma ciência capaz de levar quem a pratica a conversão, ou seja, somente os olhos dos filósofos, dos dialetas, estariam aptos a contemplar a suprema Ideia. O poder da dialética, segundo Platão, reside na capacidade do dialeta em caminhar, sem a ajuda de qualquer objeto sensível, apenas com as próprias Ideias, através das Ideias, para as Ideias. É assim que "a dialética ontológica e a dialética metafisica passam a constituir um processo único, destinado a salvar ou curar a alma", isto porque a dialética metafísica somente se realiza através da ontológica porquanto não é apenas método de fundamentação dos conceitos em ideias, mas implica o próprio homem neste processo de fundamentação: "fundamentando o conceito, o homem se fundamenta" (BORNHEIM, 1983. p. 43/44).

A dialética, para Platão, é o caminho de ascensão do homem que ao praticála é capaz de desvelar as aparências. É correto inferirmos, não obstante, que o pensamento humano, incapaz de apreender de uma única vez a verdade absoluta 
que o atrai, deve progredir tateando em direção a luz que se esvai por entre as sombras. Assim, vai deixando de lado o plano das coisas perecíveis, concretas e fixando-se no plano das Ideias, onde a Ciência encontra sentido. Da mesma forma, evidencia-se que a "caminhada em direção à luz", o percurso para alcançar a verdade, é construído através de uma cisão entre teoria e prática, entre a vida e o pensamento, cujo trajeto somente pode ser realizado por aqueles que, com seus raciocínios individuais, encontrariam as verdades ocultas, as chaves dos enigmas. Este procedimento obriga o abandono da finitude e a legitimação do "reino ideal".

Nesse sentido, a metafísica aparece como resposta possível, entre outras, à questão ontológica, ou seja, a partir da dimensão do ser explicar as diversidades ônticas, uma vez que está presente nesta corrente filosófica a busca pelo ser necessário ou pelo princípio de unidade do ser existencial. É justamente em virtude desta constatação que Platão admite a existência de uma essencialidade nas coisas comum a outras de uma mesma espécie. Não obstante, desvela-se, assim, além da objetividade lógica contida nas coisas, também uma objetividade essencial que formaria um sistema ontológico de entidades reais (HEIDEGGER, 1989). Esse mundo das essências ideais, universais, eternas, imutáveis, configurando o já conhecido "mundo das Ideias", permite ao ser se identificar com a ideia que, por sua vez, corresponde às essências, colocando-nos diante de uma concepção ontológico-metafísica do ser.

A breve discussão em torno do pensamento de Platão serviu para compreender como sua concepção de realidade, desenvolvida através da chamada dialética platônica, sugere que a dimensão inteligível do conhecimento é oriunda da Ideia, ou seja, o mundo inteligível se confunde com o próprio mundo das Ideias. Por conseguinte, é possível avançar na pesquisa e entender que é o ser quem fundamenta a ciência e cria as suas condições, já que ele é a verdade e, por isso, o conhecimento se aproxima da verdade quando também se aproxima do ser. Então temos que, para Platão, não há gnosiologia que não seja também ontologia e metafísica. 


\subsection{A modernidade em formação e a questão metafísica}

O legado científico das discussões apresentadas anteriormente ainda hoje se faz perceber em diferentes campos e de diferentes formas. A influência do legado platônico, em particular, na cultura ocidental é tão grande e estende-se a tantos campos que é muito difícil ter uma noção exata da sua profundidade e extensão. É o caso da linguística, com especial destaque à semântica, campo que assistiu a uma forte influência de uma filosofia platônica empenhada numa constante reflexão dos seres entre si. Em nosso caso, é imprescindível considerar que o ser se torna responsável e o garantidor da coerência na diversidade, que é o que caracteriza o logos. Nesse sentido, segundo Aubenque (1990), o ser se converte, em última instância, em um operador, um operador lógico com várias funções. Por conseguinte, a dialética platônica já não pensa o ser no $\log o s$, mas pensa algo que nos é fundamental: o próprio ser como logos.

Heidegger (1989) sugere, a partir de então, a confirmação de uma mutação no sentido da verdade, movimento de grande impacto que atinge a compreensão da tarefa ontológica. Aubenque (idem) afirma que o reconhecimento de uma visão estrita de ontologia da presença, da permanência conduz a um desenvolvimento "onto-lógico", uma lógica do ser, isto é, uma potencial redução do ser e do ente à uma "logicidade do ser", e considera Platão, ainda mais do que Aristóteles, o precursor da Modernidade. A despeito destas considerações, o que consideramos mais relevante é registrar que este pensamento consistiu em um grande progresso científico, nos modos de pensar a ciência, ainda que, por outro lado, como afirma Heidegger (idem), tenha acarretado um esquecimento do ser.

Segundo Aristóteles, "Há uma ciência que investiga o ser como ser e os atributos que lhe são próprios em virtude de sua natureza" (1969. p. 87). Essa ciência é a metafísica ou ciência primeira, ou ontologia, que não estuda o ser em particular, mas o ser enquanto tal. Deste modo, o estudo do ser deve incluir os princípios que a ele pertencem e o princípio basilar do ser é a lei de contradição, a qual, se enuncia assim: "O mesmo atributo não pode, ao mesmo tempo, pertencer e não pertencer ao mesmo sujeito com relação à mesma coisa [...]" (ARISTÓTELES op. cit. p. 87). A lei da contradição tem, portanto, um caráter ontológico, sendo compreendida como uma lei fundamental do ser, pois "[...] é impossível que 
asserções contraditórias sejam ao mesmo tempo verdadeiras da mesma coisa [...]" (ARISTÓTELES. Op. cit. p. 106).

A teorização aristotélica, apresentada de forma bastante breve em virtude de nossos objetivos, pode ser encarada como uma sistematização de princípios fundamentais que nortearam o pensamento anterior e posterior a si (até Hegel), e nesta organização tanto o ser (o real) como o pensamento (o lógico) estão ausentes de contradição. O ser carente de contradição é o ser idêntico a si, o ser que exclui a negação e, portanto, o movimento (CARNEIRO LEÃO, 2010). Nesta perspectiva, a essência do real é vista como o ser sem movimento, o ser substancial e imutável, a forma ou o não-sensível. Significa afirmar que não há movimento, ou melhor, que o movimento expressa apenas a aparência do ser e não a sua essência imaterial e imutável, que é o primado fundamental na determinação do ser. Assim, é o universal, imaterial e imutável, abstraído da particularidade e mutabilidade do sensível, que é posto como fundamento do real (LEFEBVRE, 1991).

Torna-se evidente como o pensamento metafisico consiste numa teoria desligada da prática, delimitando seu domínio favorito, como ensina Lefebvre (1991), nas nuvens, num além do mundo físico. Apoiados nesses posicionamentos teóricos, insistimos nas palavras de Lefebvre (idem) ao destacar que muitos metafísicos pensam da seguinte maneira:

O sujeito do conhecimento, o ser humano, é um indivíduo consciente, um eu; que é um eu? É um ser consciente de si e, portanto, fechado em si mesmo. [...] Como poderia sair de si mesmo, transportar-se para fora de si a fim de conhecer uma coisa diversa de si? O objeto, caso exista, está fora de seu alcance. $\mathrm{O}$ pretenso conhecimento dos objetos, a própria existência destes, não são mais que uma ilusão... (p. 51)

Este "cenário metafísico" predomina ao longo de todo o pensamento científico ocidental até a sistematização metafisica da realidade desenvolvida por Hegel (LIMA, 1999). É nítido que o pensamento metafísico elidiu a constatação básica de que estamos em relação com o mundo, com os objetos e com os demais seres vivos e humanos, consistindo numa relação que compõem o nosso próprio ser. Não há possibilidade do "eu” existir fechado em si mesmo, apartado do mundo e da natureza. Nestas condições, é como se o pensamento metafísico exigisse que o conhecimento apresentasse seus documentos de identidade, indagando como o 
sujeito encontra o objeto ou como a matemática e a física aplicam seus métodos no mundo real. É a partir destas elucubrações que encontramos subsídios teóricos para avançar em nossa empreitada de acordo com as proposições científicas aventadas especialmente por Descartes, Kant e Hegel, que ditaram os rumos da ciência no período moderno e que ainda encontramos fortes registros na Geografia, inclusive na prática escolar atual.

O pensamento de René Descartes (1596-1650) pode ser considerado o primeiro grande golpe sofrido pela Metafísica, inaugurando um novo momento no pensar e no fazer ciência. Movimento iniciado após o período medieval, o Renascimento assistiu ao florescimento e germinação das condições de sustentação da razão e do espírito científico. A razão concentrara, precipuamente a partir de cálculos algébricos, argumentos lógico-matemáticos capazes de reordenar a compreensão do mundo, reformulando antigas referências e servindo de base para uma nova ciência e filosofias modernas. É interessante observarmos as palavras do próprio pensador francês sobre a importância conferida à razão e ao método quando afirmou que

Como um homem que anda só e nas trevas, resolvi ir tão lentamente, e usar de tanta circunspeção em tudo, que, embora não avançasse senão muito pouco, evitaria pelo menos cair. Não quis mesmo começar a rejeitar nenhuma das opiniões que outrora se tinham insinuado no meu espírito, sem ser por intermédio da razão, antes de ter gasto bastante tempo a traçar o plano da obra que ia empreender e a procurar o verdadeiro método para chegar ao conhecimento de tudo de que o meu espírito seria capaz. (p. 17. Edição do Kindle, sem datação).

Naquele momento razão e experiência fincavam raízes suficientemente sólidas para resguardar o desenvolvimento do método científico com vistas a interromper o silogismo presente nas práticas científicas. É interessante percebermos que Bachelard (1996), a esse propósito, afirma que quando "se trata de experiências sugeridas ou construídas pela razão, a ordem é uma verdade, e a desordem, um erro" (p. 8). Bachelard está sugerindo justamente que esse par experiência-razão autorizam o avanço das investigações científicas em busca daquilo que se acredita ser a verdade. Certamente é ao redor desse pensamento que esteve justaposta ao progresso científico a crítica racional da experiência, discussão que reorienta sua organização teórica. É nesse sentido que o supracitado pensador questiona a real função de uma experiência que não retifica nenhum erro e assevera 
que "a experiência científica é portanto uma experiência que contradiz a experiência comum" (p. 14, grifos do autor). Destarte, condicionado por outra concepção científica, o período moderno assistiu ao recrudescimento de questões particulares concretas, tanto com relação ao homem, quanto com a natureza.

Com o intuito de evitar o erro emergiu, juntamente com a hegemonia da razão e revalorização da experiência, a fundamental questão de método. É correto pensarmos que a razão encontra apoio no método, legitimando-a enquanto sujeito da ciência e o mundo como objeto de sua organização. Assim, implicitamente, opera-se uma cisão, na epistemologia científica moderna, entre o sujeito e o objeto do conhecimento. Eis aí a base da ciência moderna: o método e as concreções do particular (BITETI, 2007). Ciência moderna, filosofia moderna, epistemologia científica moderna, modernidade... todos estes termos trazem em sua gênese o sentido de uma nova forma de fazer ciência e uma outra relação dos sujeitos com a ciência. Vejamos melhor em que consiste este novo sentido e suas principais diretrizes científicas de forma a consolidarmos uma trilha investigativa que permita a compreender a perspectiva ontológica presente na dimensão curricular escolar.

\subsubsection{O racionalismo e a metafísica}

Antes de avançarmos mais detidamente nos fundamentos ontológicos e epistemológicos do pensamento cartesiano, dada a sua grande importância no desenvolvimento científico, em geral, e no geográfico-escolar, em particular, é adequado escrevermos algumas linhas sobre o período histórico que estamos abordando $^{22}$ enfatizando suas principais correntes científicas - a metafísica e o racionalismo. A organização do texto não tem o objetivo de abordar as referidas correntes per se, isoladamente, mas procura delimitar como fio condutor os aspectos centrais comuns que iluminam a ontologia moderna. Certamente não é

\footnotetext{
${ }^{22}$ É bastante interessante acrescentar à essa discussão o posicionamento de Habermas (2000) que atribui a Hegel o desenvolvimento de um primeiro conceito claro de modernidade, cujo sentido, em linhas gerais, faz referência aos "novos tempos", os "tempos modernos", inspirado pelas descobertas do "Novo Mundo", pelas inovações oriundas do Renascimento e das transformações da Reforma. Hegel, segundo Habermas (idem), entende que o mundo moderno "se distingue do velho pelo fato de que se abre ao futuro, o início de uma época histórica repete-se e reproduz-se a cada momento do presente, o qual gera o novo a partir de si [...] Um presente que se compreende, a partir do horizonte dos novos tempos, como a atualidade da época mais recente, tem de reconstituir a ruptura com o passado como uma renovação contínua." (p. 11 grifos do autor).
} 
nosso objetivo desenvolver uma discussão prolongada em torno da Modernidade, mas, inescapavelmente, entendemos ser de grande valia uma maior clareza acerca do importante Século das Luzes, pois ali podem ser encontrados parâmetros teóricos fundamentais para nossa pesquisa.

A despeito de todas as discordâncias em torno de seu início e de suas posteriores heranças históricas, o ponto nevrálgico aqui é atestar o lugar de destaque conferido à ciência porquanto o discurso do saber protagoniza o conjunto de discussões da modernidade (GOMES, 1996). O período que se iniciava teve como marca uma espécie de atitude "naturalista", privilegiando a natureza e sua observação em oposição ao tema predominante da época anterior, o sagrado e a divindade, encetando uma valorização da experiência e de uma nova atitude experimental e científica. Estes novos comportamentos inspiraram o advento de uma nova ciência, demonstrando que a Terra não era o centro do universo (o heliocentrismo de Copérnico) ou o movimento em órbitas elípticas dos astros. Todas estas teorias confrontavam diretamente a ciência medieval aristotélica, que sustentava o geocentrismo e a imobilidade dos astros celestes. A inusitada proposta de Galileu (1564-1642) sobre a esfericidade e movimento do planeta Terra consubstanciou uma valiosíssima reviravolta no pensamento científico, ocasionando uma crise cultural sem precedentes na imagem segura e estável que o homem tinha do mundo, de si mesmo e de seu lugar no universo há tantos séculos.

É como se um novo código de valores se formasse, tendo por base a nova ciência surgida, todavia estilhaços da cosmovisão aristotélico-medieval se misturam às novas formas de pensar e de entender. Uma vez apresentada, a "novidade moderna" sofre a concorrência do modelo tradicional, caracterizando um período de permanente tensão, conforme Gomes (idem), entre o novo e o tradicional, especialmente através das questões de método. A modernidade envolve, por conseguinte, não apenas uma ruptura com diversas condições históricas precedentes, mas também permanências e fragmentos são registrados em seu desenrolar (HABERMAS, 2000; HARVEY, 2008).

Ao longo da modernidade muitos acreditaram que o mundo enganoso em que viviam era acarretado pela confiança nos sentidos, sendo, portanto, necessário desconfiar dos sentidos porquanto não são uma fonte confiável de conhecimento. É por demais sabido que naquele período a verdade do mundo era obtida por meio de 
uma argumentação lógica, ordenada e sistemática, pautada pelo princípio da nãocontradição, da generalização e da demonstração. Toda essa organização se tornou possível graças ao acúmulo de conhecimento obtido ao longo dos períodos precedentes e reservava um lugar central ao método lógico racional, considerado capaz de assegurar um julgamento objetivo sobre a realidade e, simultaneamente, a ciência se constitui como espaço de organização sistemática de regras e princípios que ordenam um melhor juízo. A esse respeito Harvey (2008) assinala que o

Desenvolvimento de formas racionais de organização social e de modos racionais de pensamento prometia a libertação das irracionalidades do mito, da religião, da superstição, liberação do uso arbitrário do poder, bem como do lado sombrio da nossa própria natureza humana. Somente por meio de tal projeto [denominação emprestada por Habermas] poderiam as qualidades universais, eternas e imutáveis de toda humanidade serem reveladas. (p. 23)

O sistema racional inaugurado naquele período estipulou um contínuo processo de progressão em direção às realidades finais em consonância com uma ascensão gradual do conhecimento e sustentada pelo pleno domínio da linguagem e da lógica científica. Premissa básica a partir de então, a ideia de progresso buscava desmistificar e dessacralizar o conhecimento e a organização social. O racionalismo em voga prescinde uma ideia de movimento, seja ele histórico ou científico, advogando em favor de uma alternância entre momentos de estabilidade e momentos de crise (GOMES, 1996).

Proliferaram diversas doutrinas de igualdade, liberdade, fé na inteligência humana e razão universal, muitas em virtude da crença cega no poder da ciência objetivante, que, ao mesmo tempo, desencanta a natureza e liberta o sujeito cognoscente, uma vez que a natureza passa a ser um sistema de leis conhecidas e reconhecidas. Essa realidade anunciada aos quatro ventos interrompeu uma forma de conceber e fazer ciência, repercutindo também na esfera educacional. A educação, da mesma forma que a ciência medieval de até então, viveu longo período submetida ao controle da Igreja e orientada pelo método da autoridade, ou seja, todos os conhecimentos deveriam estar de acordo com as verdades apresentadas pela Bíblia e interpretados pela autoridade papal- "Roma locuta, causa finita (Roma falou, acabou a discussão)" (PILETTI \& PILETTI, 1995) é um provérbio que dá boa dimensão do pensamento até então predominante. 
O desenvolvimento de um estatuto científico naquele período pautou não apenas a forma de fazer ciência, mas também a organização dos currículos escolares, cumprindo destacar a disciplina escolar Geografia. O método científico cartesiano praticado para desmistificação da natureza e com validação lógicoracional alcançou posição sagrada nas instituições escolares, como veremos melhor mais a frente. Neste momento faremos apenas um adendo sobre essa questão de método, tema concernente tanto à ciência quanto à filosofia e que elenca importantes discussões gnosiológicas e metafísicas. É com Descartes que tem início o primado da temática do sujeito (ou melhor, da subjetividade) sobre o objeto (ou sobre a objetividade). Assim, podemos caracterizar a metafísica na modernidade ${ }^{23}$ como a metafísica do sujeito, ou, conforme sugere Lima (1999), como uma filosofia do sujeito, o que sugere uma nova fase da filosofia a partir da afirmação do homem como sujeito. A filosofia moderna, não obstante, inverte a noção de sujeito relacionado à submissão, aquele que é submetido a algo ou a alguma coisa - para a de sustentação, ou seja, aquele que é próprio construtor de sua subjetividade, que se constrói por ele mesmo na existência. A subjetividade do sujeito passa a ser construída sem nenhuma referência a outro sujeito, consistindo em atributo de autonomia do homem e, em tempos de modernidade, a autonomia do sujeito significa autonomia do sujeito da razão: "pela razão, o sujeito é fundamento de sua própria existência” (LIMA, 1999. p. 36). Aqui reside, em nosso entendimento, um dos pilares para o "afastamento do ser", a suprema aceitação da razão como elemento de distinção e de individualização do ente.

Moutinho (2006) é certeiro ao afiançar que não há apenas o ser do sujeito ao lado do objeto, mas

Para além disso, um não dá razão do outro, um não constitui o outro, nenhum deles se afirma como meio universal; para o grande racionalismo, torna-se um problema legítimo

${ }^{23}$ É interessante mencionar o pensamento de Lander (2007) quando destaca a importância de desmontar o mito eurocêntrico, provincial e regional de modernidade, predominante no mundo. Segundo o autor, nestes termos "a Modernidade é uma emancipação, uma "saída" da imaturidade por esforço da razão como processo crítico que abre a humanidade a um novo desenvolvimento do ser humano, processo essencialmente cumprido na Europa no século XVIII" (p. 224). A Modernidade estaria circunscrita ao continente europeu, relacionada a fenômenos "intra-europeus" e seu desenvolvimento ulterior não precisa mais do que a Europa para explicar o processo. Por outro lado, cabe ressaltar, ainda que não nos sirva de parâmetro, a proposta de Foucault (1987) em identificar duas grandes descontinuidades na episteme da cultura ocidental: a que ele denomina de idade clássica (inaugurada por volta do século XVII) e aquela que marca o limiar de nossa modernidade, situada no início do século XIX. 
compreender a relação entre o exterior e o interior, entre o corpo e a alma (p. 192/193)

O postulado cartesiano provoca mudanças radicais no pensamento metafísico ao deslocar a busca por fundamentos ontológicos e epistemológicos de um ser absoluto para a subjetividade do sujeito - cogito ergo sum. Lefebvre (1981), acerca desta temática, declara que Descartes, portador de uma audácia transcendente, é o primeiro dos grandes “decodificadores modernos” por organizar o domínio da natureza pela matemática e pela quantificação, obrigando o filósofo a refletir de acordo com a perspectiva racionalista. Destarte, o pensamento de Descartes redireciona importantes pilares da filosofia ao redesenhar a metafísica, consagrar o raciocínio matemático e lógica racional e circunscrever o racionalismo a um corpo metodológico capaz de construir sistemas explicativos.

Compondo este debate é válido retomarmos a experiência científica de Descartes, que, como é sabido, confere extremo valor à uma postura permanentemente indagadora. Esta constatação nos faz entender melhor sua preocupação em responder de outro modo aos problemas já que as respostas anteriores fracassaram. Descartes, portanto, impõe ao seu empreendimento o fito de reconstruir toda a ciência em novos e sólidos alicerces porquanto os fundamentos anteriores estavam já bastante abalados ${ }^{24}$. É relevante realçarmos que o projeto cartesiano defende a fundação de uma ciência universal, fundamentada em princípios claros e evidentes, a partir da universalidade do método. A mathesis universalis é convertida em método comum universal, que, se bem aplicado por todos, levará necessariamente a que todos cheguem ao mesmo resultado, ou melhor, ao verdadeiro conhecimento, e se todas as ciências a utilizarem chegaremos a uma unidade metodológica.

O princípio da ciência, no interior dessa proposta, reside na incerteza e a dúvida persistentes e estão intimamente relacionadas ao desejo de oferecer respostas puramente verdadeiras, iluminadas pela razão através do método científico. Essa faceta revela que a dimensão gnosiológica, conjuntamente à questão

\footnotetext{
${ }^{24}$ O próprio Descartes faz uma analogia interessante para ilustrar seu pensamento: "É certo que nunca se viu derrubarem-se todas as casas duma cidade, só com a intenção de as refazer de outra maneira e de tornar assim as ruas mais belas; mas o que se vê é muitos deitarem a baixo as suas para as reconstruir, sendo mesmo algumas vezes forçados a isso, quando elas correm risco de cair por si, por seus alicerces não serem bem firmes" (Ebook Kindle sem datação, p. 16).
} 
do método, no interior do edifício cartesiano, são temas de primeira ordem, antecedendo a metafísica, porquanto trata-se de saber a possibilidade de conhecer e, em caso positivo, como e quais aspectos esse conhecimento tem de ter para ser verdadeiro, ou seja, para se tornar, de fato, conhecimento. Não é correto pensarmos que o filósofo francês relega a metafísica a discussão de menor importância, mas, apenas, que existem questões que a precedem.

Assim, Descartes evidencia de forma transparente que suas preocupações não se limitam à teoria do conhecimento (lógico), mas também abarcam a metafísica ao escrever que

Deve-se estudar a Lógica que ensina a bem conduzir a razão com o objectivo de descobrir as verdades desconhecidas; e porque depende bastante do uso, o estudioso deve exercitar-se durante algum tempo a praticar as regras referentes a questões fáceis e simples, como as das Matemáticas. Então, desde que haja adquirido o hábito de encontrar a verdade nestas questões, deve começar a aplicar-se à verdadeira Filosofia, cuja primeira parte é a Metafísica, que contém os princípios do conhecimento, entre os quais se encontra a explicação dos principais atributos de Deus, da imaterialidade das nossas almas e de todas as noções claras e simples que residem em nós. (p. 21)

Por conseguinte, se porventura, houver alguma coisa que a dúvida radical não consiga desmentir, então pode ser que tenhamos encontrado a rocha firme onde é possível edificar a verdade. É seguindo este dogma de uma dúvida hiperbólica que o próprio Descartes (idem) escreve que

Todo o meu intuito era conquistar a certeza e rejeitar a terra movediça e a areia, para encontrar a rocha ou a argila. $\mathrm{O}$ que me deu muito bom resultado, segundo me parece, tanto mais que, procurando descobrir a falsidade ou a incerteza das proposições que examinava, não por fracas conjeturas, mas por raciocínios claros e seguros, não encontrava nenhumas tão duvidosas que delas não tirasse sempre alguma conclusão bastante certa, quando mais não fosse a de não conterem nada de certo. (p. 22)

Sabendo que o pensamento cartesiano encontra sua motivação investigativa no desejo de encontrar verdades irrefutáveis e universais capazes de balizarem novas descobertas posteriores é possível afirmar que "toda a estrutura de conhecimento invalidada pelo exame da dúvida poderia ser reconstruída a partir de um novo parâmetro que constituiria a base do próprio conhecimento" (LIMA, 2013. p. 33). O procedimento científico cartesiano, portanto, submete toda e qualquer 
coisa - fenômenos, processos, matérias, crenças - ao exame da dúvida minuciosa, restando como única certeza a ideia de sua própria existência enquanto ser pensante, uma vez que

Só é possível duvidar do cogito (pensamento) através do próprio cogito: o ato de duvidar entendido então como um modo de pensar, de onde se infere a sua máxima "cogito ergo sum" ("penso, logo, existo"), porquanto a certeza da existência se evidencia pelo ato da dúvida como expressão do pensamento $(\text { ibidem })^{25}$.

É possível identificar que seu pensamento parte de uma dúvida metódica, buscando superá-la mediante a certeza e uma das certezas indiscutíveis é a da existência, pois não haveria possibilidade de enganar-se caso não existisse, logo se penso, sou. Assim, Descartes, segundo Lefebvre (1981),

Identifica intrepidamente o ser e o pensamento. Não há falha, entre eles não há fissura. 'Penso, logo sou'. Ser é pensar. O pensamento é. O pensamento do ser é o ser. O pensamento é idêntico a si mesmo. Pensar é pensar [...] Por conseguinte, para toda a escola cartesiana, o pensamento de Deus se identifica com Deus. (p. 137, tradução livre)

O posicionamento de Lefebvre evidencia que Descartes sobrelevou o método matemático a uma forma de conhecimento geral da realidade, ainda que esbarrando na validade da razão humana, isto é, a legitimação do conhecimento matemático tem de ser auferida pelo pensamento. Descartes, outrossim, mergulha na questão gnosiológica ao relacioná-la com a metafísica, instituindo não apenas uma metafisica do ser, mas também do pensamento, o que significa que com Descartes a ideia sofre uma ressignificação: "passa a ser considerada um ato mental subjetivo que não necessita de uma objetividade correspondente para existir no

\footnotetext{
${ }^{25}$ É válida a observação das palavras do próprio Descartes (Ebook Kindle, 2019) quando escreve que "Assim, porque os nossos sentidos nos enganam algumas vezes, eu quis supor que nada há que seja tal como eles o fazem imaginar. E, porque há homens que se enganam ao raciocinar, até nos mais simples temas de geometria, e neles cometem paralogismos, rejeitei como falsas, visto estar sujeito a enganar-me como qualquer outro, todas as razões de que até então me servira nas demonstrações. Finalmente, considerando que os pensamentos que temos quando acordados nos podem ocorrer também quando dormimos, sem que neste caso nenhum seja verdadeiro, resolvi supor que tudo o que até então encontrara acolhimento no meu espírito não era mais verdadeiro que as ilusões dos meus sonhos. Mas, logo em seguida, notei que, enquanto assim queria pensar que tudo era falso, eu, que assim o pensava, necessariamente era alguma coisa. E notando que esta verdade - eu penso, logo existo, era tão firme e tão certa que todas as extravagantes suposições dos céticos seriam impotentes para a abalar, julguei que a podia aceitar, sem escrúpulo, para primeiro princípio da filosofia que procurava" (p. 24).
} 
plano metafísico do pensamento" (BITETI, 2007. p. 75). Em virtude desta conduta, o filósofo francês estrutura uma formulação teórica rigorosa acerca de uma ontologia científica de mundo, possibilitando à ciência o estatuto de saber universal e verdade infalível. Lima (2013) nos ensina que a influência cartesiana

Deve-se menos à sua teoria do conhecimento em si mesma do que ao caráter metafísico e abstrato de que se revestem suas teses: uma ontologia cientificista substancialista que fundamenta um objeto exterior (objeto da ciência), demandando a crença de um ser em si; confrontada com uma ontologia racionalista substancialista, índice do subjetivismo filosófico, concepção esta correlata à ideia de uma essência interior e um ser para si (p. 33 grifos do autor).

Neste momento de nosso estudo entendemos ser enriquecedor apontar algumas considerações sobre o conteúdo da ideia apresentada na citação acima. Contrapondo sua ontologia cientificista à uma ontologia racionalista, Descartes parece dar fim ao acordo entre metafísica e ciência e estrutura as bases para autonomização do ser visado pela ciência enquanto a ciência da natureza se torna a medida do ser (MOUTINHO, 2006). É em meio a estas teses que adquire maior relevância, ao longo da modernidade, a ideia de que a Metafísica deixa de lado a perspectiva de refletir sobre a realidade como tendo um único fundamento, seja ele o ser eterno, absoluto, pura essência; e adota como prioridade o caminho da fundamentação ontológica através da subjetividade do sujeito (racional) que conhece e constrói ideias distintas e claras (LIMA, 1999). Dessa forma é possível afirmar que, em termos ontológicos, a filosofia, com Descartes, deixa de ser metafísica e se consolida como doutrina do pensar e do conhecer ${ }^{26}$, ou seja, não é mais o ser que condiciona o pensamento, mas é o pensamento que adquire centralidade em relação ao ser - espírito e corpo são dissociados entre res cogitans e res extensa, respectivamente, indicando uma irredutibilidade entre espírito e matéria ${ }^{27}$.

\footnotetext{
${ }^{26}$ Ao mesmo tempo, segundo Foucault (1987), o saber devia dar conta dos signos que recobrem o mundo e demandam que sejam decifrados, ou seja, conhecer é, também, interpretar: "ir da marca visível ao que se diz através dela e, sem ela, permaneceria palavra muda, adormecida nas coisas" (p. 48).

${ }^{27}$ Complementar à análise que desenvolvemos está a visão de Lander (2007), enfatizando alguns aspectos desta nova perspectiva (eurocêntrica) de conhecimento que estabelece um novo padrão (colonial) mundial de poder, com destaque para o radical dualismo cartesiano, ou seja, a total separação entre "razão/sujeito" e "corpo", a partir do qual o "corpo" foi naturalizado, fixado como "objeto" de conhecimento, por parte da "razão/objeto". Esta separação (abstração) do sujeito/razão em relação ao corpo "está na base das pretensões objetivistas e universalizantes de um saber
} 


\subsubsection{A ciência moderna em construção}

De posse desse posicionamento e avançando em nossa pesquisa é possível inferir que, em virtude de suas proposições filosóficas e científicas, Descartes pode ser considerado um marco na marcha de desenvolvimento do conhecimento europeu ao estabelecer as bases do "logos europeu"28, como diz Lefebvre (1981), das principais representações de sociedade e de natureza: "o espaço mental e a eficácia, a ordem e a medida, a quantificação, e a lógica matemática" (p. 138). Não à toa seu pensamento encontra ressonância ideológica e pedagógica posterior em diversos campos, como a própria seara geográfica e a pedagógica, onde observamos a predominância do "individualismo e do racionalismo (mesmo que com contradições), o dogmatismo e logocentrismo, a egologia do sujeito 'dono de si e do universo' e a ideologia correspondente" (ibidem).

Correlato a essa ideia está o posicionamento de Lander (2005) para quem o pensamento cartesiano pode ser inscrito como um marco histórico significativo de sucessivos processos de separação - que na tradição ocidental se revela num primeiro momento na origem religiosa através da separação judaico-cristã entre Deus (o sagrado), o homem (humano) e a natureza -, representando a ruptura ontológica entre corpo e mente, entre a razão e o mundo. Por conseguinte, é adequado inferir que

A compreensão do mundo já não é uma questão de estar em
sintonia com o cosmos, como era para os pensadores gregos
clássicos. O mundo tornou-se o que é para os cidadãos do mundo
moderno, um mecanismo desespiritualizado que pode ser

(científico) que reivindica sua separação dos condicionamentos subjetivos (corporais), espaciais e temporais" (p. 225).

${ }^{28}$ Com fito de melhor explorar o contexto teórico daquele período cabe realçar a discussão em torno das questões relativas ao conhecimento do sensível, onde emerge com expressivo destaque o empirismo crítico de Locke. Segundo Biteti (2007), Locke promove "uma crítica à metafísica espiritualista de Descartes que destacava a importância do intelecto humano no processo do conhecimento" e avança ao afirmar a filosofia como pura gnosiologia ou problema crítico do conhecimento e, não obstante, acredita que a "experiência permite apreender os limites do conhecimento, e somente através da experiência o conhecimento humano em eficácia" (p. 76). Contrário às ideias inatas, Locke acreditava que todo o conhecimento vem inicialmente das sensações, o que, todavia, não exclui o nível interno da reflexão. O que significa que o conhecimento "é dado pela percepção de uma relação, que é, ao mesmo tempo, experiência externa da percepção e estabelecimento de uma relação, logo, de uma representação abstrata" (GOMES, 1996. p. 75). Ainda é preciso salientar que, seguindo este raciocínio, "a natureza age em constância e regularidade, cabendo à razão o papel de extrair, a partir da impressão imediata, correlações fenomenais e estabelecer uma representação abstrata" (ibidem). 
captado pelos conceitos e representações construídos pela razão (APFFEL-MARGLIN, 1996. p. 3 apud LANDER, 2005. p. 8).

É somente através destas separações, bases para um conhecimento “descorporizado" e "descontextualizado", que se torna possível esse tipo particular de conhecimento que se pretende objetivo e universal. A radical ruptura apresentada por Descartes consiste, em suma, em colocar em mundos opostos o sujeito pensante e o mundo exterior pensado, incluindo o próprio corpo e todas as formas objetivas de envolvimento com o mundo. Portanto, o corpo figura como mais um objeto exterior, dotado e limitado em suas composições físico-químicas, distinto do sujeito pensante que observa e formula racionalmente o mundo ao seu redor. Sem corporeidade, o sujeito não pode ser localizado, permanecendo sem lugar no domínio da extensão.

Descartes operou uma espécie de separação do sujeito e da subjetividade do outro, colocando em destaque o plano individual, a consciência de si como suporte autossuficiente de toda a racionalidade científica. Nesse sentido, o outro torna-se uma mera extensão do sujeito, quando, na realidade, deveria ser compreendido no interior do próprio eu (LIMA, 2013). Aqui reside uma questão preambular voltada à compreensão do sujeito como um ente individual cognoscente, escapando a necessária consideração de sua constituição a partir da relação com outros sujeitos. Apoiado naquele procedimento cartesiano, a ciência cindiu o sujeito de seu derredor e o colocou em correspondência com o indivíduo, a pessoa, o eu. Deslocado em sua gênese epistemológica, é também tolhido de sua relação dialética entre o particular e o coletivo, entre a parte e o todo.

É evidente que, diferentemente desta premissa científica cartesiana, pensamos ser imprescindível a presença do corpo para que o sujeito possa ser situado no tempo e no espaço. A cisão entre res cogitans e res extensa concebe que tudo no mundo é espacial, exceto o "eu", instaurando uma ontologia fundamentada na dicotomia entre espaço e homem. Cindir o "eu" do espaço, prescrever uma ciência objetiva e universal, separar o sujeito pensante do objeto de estudo são algumas das transformações que ocorreram na ciência moderna e que são, de forma até bastante frequente, retóricas discursivas presentes na realidade escolar contemporânea. Dado nosso objetivo e porquanto separamos uma seção adiante para tratarmos especificamente a questão geográfico-curricular com maior ênfase, 
faremos um pequeno adendo à herança pedagógica do pensamento cartesiano de acordo inicialmente com uma proposição de Bachelard com o simples intuito de traçar alguns vínculos explícitos de proximidade entre essas questões.

Bachelard (1996) é extremamente preciso quando aborda, logo no início de seu livro, os estágios do pensamento científico e enumera o que ele denomina como a lei dos três estados da alma, caracterizados por interesses ${ }^{29}$. Dentre esses estados, gostaríamos de destacar um em especial que estabelece forte vínculo entre a proposta cartesiana e suas marcas reminiscentes na organização das práticas escolares:

Alma professoral, ciosa de seu dogmatismo, imóvel na sua primeira abstração, fixada para sempre nos êxitos escolares da juventude, repetindo ano após ano o seu saber, impondo suas demonstrações, voltada para o interesse dedutivo, sustentáculo tão cômodo da autoridade, ensinando seu empregado como fazia Descartes, ou dando aula a qualquer burguês como faz o professor concursado (p. 12 grifos do autor).

É bastante curiosa a relação construída pelo autor em torno de uma alma professoral em que prevalece a ideia de perpetuação ou de permanências, de um lado, das mesmas práticas pedagógicas e, por outro lado, dos mesmos saberes/conteúdos. Esse estado sugere que o detentor de uma alma professoral não está voltado às transformações, está distante das mudanças, perfilado junto às constâncias repetitivas de uma mesma rotina, ou seja, afastado da realidade prática do mundo, desatento aos eventos e reordenações históricas. É esse olhar professoral que predomina no espaço escolar e que desacredita sua própria constituição por estar circunscrito aquilo que pretensamente parece permanecer, situação bastante indicativa de que um dos espaços por excelência da razão opera uma nítida separação entre o objeto e o sujeito do conhecimento.

\footnotetext{
${ }^{29}$ Os outros estados apontados pelo autor são a alma pueril ou mundana - "animada pela curiosidade ingênua, cheia de assombro diante do mínimo fenômeno instrumentado, brincando com a física para se distrair e conseguir um pretexto para uma atitude séria, acolhendo as ocasiões do colecionador, passiva até na felicidade de pensar" - e a alma com dificuldade de abstrair e chegar a quintessência - "consciência científica dolorosa, entregue aos interesses indutivos sempre imperfeitos, no arriscado jogo do pensamento sem suporte experimental estável; perturbada a todo momento pelas objeções da razão, pondo sempre em dúvida o direito particular à abstração, mas absolutamente segura de que a abstração é um dever, o dever científico, a posse enfim purificada do pensamento do mundo!" (BACHELARD, 1996. p. 12/13)
} 
À realidade abordada acima coadunamos a elaboração das chamadas "leis da natureza", símbolo da profunda separação que vemos debatendo, cuja proclamação acarretou transformações em diversos campos científicos. Enunciadas pela física, têm como objetivo descrever a mudança ao caracterizar a variação, ao longo do tempo, dos movimentos por uma velocidade. A lei de Newton, como já sabemos, é o melhor exemplo dessa "vitória" por consistir, em suma, num triunfo do ser sobre o devir, uma vez que se sabemos as condições iniciais de um sistema, seu estado num instante qualquer, podemos calcular todos os estados seguintes, bem como todos os estados passados. Mesmo destronada no século XX pela mecânica quântica e pela relatividade, a física de Newton permanece em seu determinismo e em sua simetria temporal (PRIGOGINE, 2011).

Esse modo (moderno) de fazer ciência e entender a realidade não difere daquilo que encontramos ainda hoje no espaço escolar. A Geografia escolar sustenta-se, em grande medida, nessa conduta. Separar o homem do espaço, cindir a realidade em (i)materialidades opostas, prever fenômenos, permanecer vinculada a aparências fenomênicas são alguns comportamentos prático-docentes persistentes, ainda que com algumas variações, desde a pretérita até a hodierna "aula de Geografia" no Brasil. Discussão que desenvolveremos melhor mais a frente, cabe, neste momento, à guisa de uma melhor contextualização de nossa temática, afirmar que a disciplina escolar Geografia encontra suas matrizes curriculares na Geografia Clássica e na Geografia Moderna ${ }^{30}$, através de uma seleção intencional de conteúdos.

Assim é tornado possível inferir que há bastante tempo tomamos como referência um espaço esvaziado de sujeitos, produto a-histórico, e aqueles que nos assistem em nossa explanação não se compreendem, por conseguinte, participantes de nenhum processo, mas apenas meros espectadores de uma realidade apresentada como algo que não lhes pertence. Bachelard (1996) endossa nosso posicionamento

\footnotetext{
${ }^{30}$ Estas denominações serão devidamente explicitadas quando adentrarmos com maior minúcia no interior das práticas da Geografia Escolar, todavia é sabido que a Geografia Clássica, ainda não sistematizada enquanto conhecimento, está estritamente vinculada a descrição de paisagens diversas e aos modelos matemáticos de cálculo da superfície terrestre; enquanto a Geografia Moderna, momento que este conhecimento já estava sistematizado, erige, no final do século XVIII, sobre bases positivistas, como uma ciência de caráter empírico, pautado na observação e na unidade metodológica - a reconhecida "ciência de síntese". Tatham (1960) ensina que a Geografia, enquanto ciência sistematizada, nasceu a partir da metade final do século XVIII, mas trata-se de uma ciência bastante antiga, tendo suas raízes na Antiguidade.
} 
na referência feita sobre um livro de ensino científico moderno, ponderando que ali a ciência é apresentada como que

Ligada a uma teoria geral. Seu caráter orgânico é tão evidente que será difícil pular algum capítulo. Passadas as primeiras páginas, já não resta lugar para o senso comum; nem se ouvem as perguntas do leitor. Amigo leitor será substituído pela severa advertência: preste atenção, aluno! O livro formula suas próprias perguntas. O livro comanda. (p. 31)

É importante salientar que não estamos filiados à nenhuma concepção que toma as disciplinas escolares como prisioneiras das suas ciências ou saberes de referência e da pedagogia, procedimento que as limitariam a pedir das primeiras o conteúdo de seu ensino e da segunda os métodos e processos para a reprodução daqueles (SAVIANI, 1994). Todavia acreditamos que as disciplinas escolares, cada uma ao seu modo, se especializam em seguir, passo a passo, em seus ensinos, o desenvolvimento apresentado pelas ciências que lhes dão sustentação científica.

Vemos agora com maior clareza que a ciência (moderna) constituída esteve calcada na objetividade para alcançar o maior grau possível de impessoalidade e isenção na análise dos fenômenos e dos objetos, impedindo que julgamentos individuais sejam obstáculos a uma visão geral que possa ser partilhada por todos. As leis da natureza, por exemplo, são da esfera de um conhecimento ideal que alcança a certeza, tornando a natureza um autômato que podemos, em princípio, controlar (PRIGOGINE, 2011). A novidade, a escolha, a atividade espontânea são apenas aparências relacionadas ao ponto de vista humano. É justamente dessa forma que a ciência persegue um escopo objetivo, uma garantia imparcial, tornando o sujeito "desterritorializado" na ciência. A fundamentação objetivista da ciência define não existir qualquer concessão às subjetividades na interpretação dos fenômenos, tornando a inteligibilidade do real atrelada ao rigor metodológico, à precisão das manipulações formais, às explicações causais, aos modelos quantitativos e taxonômicos e a um conjunto de procedimentos operacionais acerca do qual a física e a matemática se consagram como arquétipos de cientificidade (LIMA, 2013). É fomentada também a produção de uma própria "lógica" a ser compartilhada por todos os que produzem um determinado conhecimento, estimulando a inibição de preferências pessoais e de idiossincrasias. Feyerabend (1977) afirma que os sujeitos vêm sua imaginação restringida e até sua linguagem 
deixa de ser própria, o que torna a natureza dos fatos científicos "vistos como independentes de opinião, de crença ou de formação cultural” (p. 27).

Ao observamos nossa trajetória desde o início deste capítulo até aqui vemos que foi apresentado e discutido um grande volume de ideias. Recuperando a ideia de que os filósofos pré-socráticos não viam o conhecimento como a relação sujeitoobjeto, como fazem os cientistas modernos, e perseguiam em suas filosofias o conhecimento da gênese de tudo, o princípio universal, talvez nos ajude a entender que o período precedente à modernidade adquirisse um cunho religioso tão forte. A origem de nossa existência consistiria em um problema teológico, cuja discussão era de acordo com as ordens de Deus. Platão, filósofo que tomamos como referência teórica, discípulo de Sócrates, aprendeu com seu mestre a importância de pensar por conceitos, criando uma verdade inteligível de caráter universal. Com base nas ideias socráticas, a filosofia atribuiu valor universal ao conhecimento e não propriamente ao ser.

Já a ciência, em sua dimensão epistemológica moderna, estabelecia a dicotomia espaço-homem de forma estruturante promovendo uma espécie de "desespacialização" do homem e, consequentemente, legitima a ideia de que os corpos deixam de ser espaciais para estar no espaço (MOREIRA, 2012). Assim, a "geometrização do mundo", por meio da física newtoniana, adquire status de verdade universal ao apresentar a separação dos entes corpóreos entre os corpos físicos (sem vida) e os corpos vivos (corpo humano), bem como espaço e corpo são dissociados em sua generalidade, reproduzindo, por meio de rigorosos métodos científicos, as relações do espaço com o homem, cujas demonstrações matemáticas certificam a existência tricotômica que separa homem, espaço e natureza. Cumpre frisar que esta separação, segundo Moreira (2012), não é um ato desprovido de interesse, mas trata-se, na verdade, "de um pacto estabelecido entre a religião e a ciência no correr do Renascimento, decidindo caber à ciência o mundo físico e à religião, o metafísico" (p. 134).

Notoriamente edificada sobre seu caráter objetivo, a ciência impõe o objeto científico como verdade incontestável para todos os sujeitos e transforma toda impressão pessoal em resíduo irrelevante, o que torna o homem mero objeto, convertido em elemento pertencente a um grupo biológico, simples espécie animal explicada por estudos físico-químicos. Assentada nesta premissa, a ciência afirma 
não existir conhecimento sem objeto a conhecer, ou seja, não existe ciência da natureza sem uma natureza, apregoando que existe, antes de nós e sem nós, um mundo exterior que é conhecido por diferentes ciências, como a física, a química, a biologia, a geologia etc. (LEFEBVRE, 1991).

Complementar à essa imposição objetiva da ciência está a ausência da dimensão temporal nos procedimentos científicos. É bastante interessante observarmos que Lima (2013) assinala esse fato como uma das principais razões para a ausência do homem, e consequentemente dos sujeitos, nas ciências, delineando um perfil a-histórico que torna o homem um estranho em sua própria esfera de trabalho. O tempo histórico sempre foi encarado como uma ameaça aos preceitos universalistas da ciência, constituindo, desse modo, uma dimensão objetiva, produto da intuição e da intersubjetividade humana, o que lhe conferiu um teor universalista (idem).

A constatação do supracitado autor encontra reação somente quando verificamos como o tempo passou a organizar estudos em diferentes ramos científicos, como inicialmente ocorreu na física em sua perspectiva termodinâmica. Esta reação pode ser considerada uma das expressões científicas de um movimento de maior amplitude, incluindo também a biologia (darwinismo) e materialismo o histórico-dialético no conjunto das ciências humanas. Neste sentido, é possível verificar a percepção da dimensão temporal diversas pesquisas, como a evolução geológica da superfície terrestre, das espécies biológicas, da sociedade, dos modos de produção etc (LIMA, 2013). Prigogine (2011) recentemente escreveu que o "tempo precede a existência" (p. 173), conduzindo outro espinhoso debate em torno do tempo que tem como foco o fenômeno do big bang e de sua consideração como origem do universo seria equivalente a aceitação de que o tempo tem um ponto de partida, havendo, por conseguinte, um começo e, talvez, um fim do tempo.

Einstein com sua teoria da relatividade, fundamento da cosmologia contemporânea, vaticina que o universo está em constante expansão e que se voltarmos no tempo chegaremos a uma singularidade, isto é, um ponto que contém a totalidade de energia e de matéria do universo (ibidem). Lewis Carrol, autor inglês de Alice no país das maravilhas, nos brinda com um curto diálogo capaz de dar a dimensão deste debate quando a jovem Alice questiona o Coelho sobre a duração 
da eternidade e recebe como resposta a possibilidade da relatividade: "Às vezes apenas um segundo".

O debate em torno do tempo nos é bastante importante porque permitiu superar em parte os limites da ontologia cientificista. A difusão dos relógios (do século XIV em diante) e as intermináveis voltas do ponteiro encontram, em meados do século XVII, seu ponto de ápice graças à grande aceitação das teorias de Newton, que concomitantemente, se espalham tanto na vida íntima quanto é consagrado na organização do tempo do trabalho (THOMPSON, 1998). Em qualquer nível que seja, as ciências confirmam nossa experiência da temporalidade: "vivemos num universo em evolução" (PRIGOGINE, 2011. p. 163). A inclusão do tempo na pauta científica permitiu, em última instância, a aceitação da vida em devir e, assim, do homem.

Mais uma vez a metafísica é golpeada. Seus seguidores acreditavam na tese de que as verdades se revelavam de modo súbito, global, a quem as buscasse. Todavia este sistema consiste em ser rigorosamente incompatível com toda teoria do conhecimento que admite um devir, uma história, que assiste a um progresso da ciência (LEFEBVRE, 1991). É o desenrolar desta marcha de aceitação e inclusão do tempo que permite superar aquela ontologia cientificista de cunho universalista e pautada por uma objetividade e exterioridade puras. É buscada uma nova forma de posicionamento do problema ontológico entre o sujeito e o objeto de maneira que nenhum deles se afirme, nas palavras de Lima (2013), "como meio universal ou princípio absoluto, sem que um determine o outro, porquanto cada qual passa a constar como uma unidade relativa ao todo e não entre si” (p. 39). Nem objeto puro, livre de predicados, nem sujeito puro, pensador que está acima do objeto; nem ontologia cientificista, sedenta por encontrar objetos puros, preexistentes ao sujeito, nem idealismo, que desconsidera inteiramente o sujeito (MOUTINHO, 2006).

A nova fase da ciência, agora provida da consideração temporal, não nos permite asseverar que a concessão ao sujeito se deu integralmente ao longo de seus processos investigativos. Este tema exige um pouco mais de cuidado em sua abordagem. É fato que a revisão do conhecimento, em grande medida orientada pela crítica ao objetivismo, acarretou a perda de prioridade do universalismo típico cartesiano, sinalizando que, a partir daquele momento, o sujeito seria aceito no 
âmbito das ciências, mesmo sem qualquer critério de validade, apenas para não mais reproduzir o objetivismo.

Todavia é imprescindível esclarecer que as ulteriores descobertas científicas não livraram a ciência de seu cunho objetivista, como bem demonstra os intentos alcançados pelos próprios físicos, que convivem até hoje com uma dupla herança do século XIX: de um lado, as leis de Newton, que correspondem a um universo estático, e, de outro lado, a descrição evolutiva associada à entropia, elemento essencial introduzido pela termodinâmica, a ciência dos processos irreversíveis, ou seja, orientados no tempo (PRIGOGINE, 2011, grifos nossos) ${ }^{31}$. Contudo, não podemos tomar este segundo caso como um referencial geral para as ciências, que mormente privilegiam a normatização do tempo, a simetria temporal presente nos preceitos básicos da ciência clássica, indicativas de sua propensão a um objetivismo de tipo particular, do específico, da partícula.

O cenário descrito acima aponta bastante claramente que o raciocínio científico, em diferentes searas, ganha também contornos de uma incessante busca por objetividade a ser lograda através da exatidão e da coerência dos atributos e não pela reunião de objetos mais ou menos análogos. Este procedimento está empenhado em especificar, limitar, purificar substâncias e fenômenos, indicando, segundo Bachelard (1996), que o cientista moderno de então é caracterizado pela objetividade e não pelo universalismo: "o pensamento deve ser objetivo, só será universal se puder, se a realidade lhe permitir". Nesse sentido, muitas vezes, o que limita o conhecimento é "mais importante para o progresso do pensamento do que aquilo que estende vagamente o conhecimento" (p. 81).

Portanto, se a ciência clássica se edificou, pautada numa ontologia objetivista sem abrir qualquer brecha à entrada do sujeito, a ciência moderna delimita ao sujeito o espaço da passividade, delineando a instauração do "paradigma de conhecimento pós-cartesiano que não mais o restringe a um ego fundador, centrado e reflexivo" (LIMA, 2013. p. 40). É Foucault (1987) quem escreve valiosas linhas sobre as transformações daquele período ao mostrar que a

\footnotetext{
${ }^{31}$ É bastante revelador o pensamento de Prigogine (2011) ao afirmar que a "distinção entre processos reversíveis e irreversíveis é introduzida na termodinâmica pelo conceito de entropia" (p. 25). Assim, segundo o mesmo autor, "contrariamente à energia, que se conserva, a entropia permite estabelecer uma distinção entre os processos reversíveis, em que a entropia permanece constante, e os processos irreversíveis, que produzem entropia" (p.26).
} 
vida assume (certa) autonomia em relação aos conceitos de classificação procedimento de distribuição em que o saber da natureza separava a vida por classes - significando que "a vida torna-se objeto de conhecimento em meio aos outros e, a esse título, está sob a alçada de toda a crítica em geral" e, por outro lado, "resiste também a essa jurisdição crítica que ela retoma por sua conta e que reporta, em seu próprio nome, a todo conhecimento possível” (p. 178).

As palavras de Foucault buscam refletir a necessária "libertação" da vida, incluindo os sujeitos das amarras impostas pelo fazer científico anterior, ainda que, é sempre bom reforçar, esse movimento não ocorra uniformemente. $\mathrm{O}$ final do século XVIII assiste a uma nova organização do espaço do saber, mais distante de ordens não-quantitativas, de uma caracterização universal, de uma taxonomia geral e próxima de uma abordagem que privilegia as relações internas entre os elementos, cujo conjunto assegura uma função, bem como "mostrará que essas organizações são descontínuas, que não formam, pois, um quadro de simultaneidades sem rupturas, mas que algumas são do mesmo nível enquanto outras traçam séries ou seqüências lineares" (FOUCAULT, 1987. p. 232). No entanto, não podemos perder de vista em nosso estudo a prevalência ainda da razão, transformada em instituição no final do século XVIII, consistindo em inesgotável fonte para as normas, para o conhecimento e verdade. O sistema moderno construído até então passava a simbolizar, de maneira geral, o principal veículo de difusão da ordem, do equilíbrio, da civilização, do progresso, únicos meios de acesso a um mundo verdadeiramente humano. Constatamos, em vista disso, que a modernidade constrói sua identidade sob um duplo aspecto: de um lado, o território da razão, das instituições, do saber metódico e normativo; de outro lado, diversas "contracorrentes", movimentos de oposição à supremacia exclusiva da razão e do espírito científico universalizante (GOMES, 1996).

É interessante percebermos que nessa questão está imbricado o processo de constituição da ciência geográfica, movimento que veremos com maior detalhe no terceiro capítulo, mas que não podemos nos furtar de tecer algumas considerações neste momento. A transformação da ciência ocidental que permitiu a constituição das ciências humanas (como a sociologia, a psicologia, a história) revela uma alteração da concepção do homem, em que espírito e corpo passam a ser vistos como substâncias separadas, em que cada qual atua independentemente da outra, 
de acordo com leis próprias, o que, por conseguinte, permitiu acrescentar o homem como objeto atuante na superfície terrestre. Em suma, o próprio Foucault (2000) em outro estudo nos mostra com bastante clareza que até o século XVIII as ciências humanas não existiam simplesmente porque na episteme clássica o homem se vê como integrante da natureza, ou mais precisamente ele se reconhece nela "por imagem ou por reflexo".

Até então não há distinção entre "natureza" e "natureza humana", significando que somente quando o edifício da episteme clássica desmorona é que o homem aparece em sua dupla condição de objeto para um grupo de ciências e de sujeito cognoscente para outras, acarretando numa redistribuição do saber e numa reorientação do desenvolvimento da ciência. Assim, nos escreve o filósofo francês:

Antes do fim do século XVIII, o homem não existia. [...] É uma criatura muito recente que a demiurgia do saber fabricou com suas mãos há menos de 200 anos: mas ele envelheceu tão depressa que facilmente se imaginou que ele esperara na sombra, durante milênios, o momento de iluminação em que seria enfim conhecido. [...] Sem dúvida, as ciências naturais trataram do homem como de uma espécie ou de um gênero: a discussão sobre o problema das raças, no século XVIII, o testemunha. [...] Mas não havia consciência epistemológica do homem como tal. A epistémê clássica se articula segundo linhas que de modo algum isolam um domínio próprio e específico do homem. E se se insistir ainda, se se objetar que nenhuma época, porém, concedeu tanto à natureza humana, deu-lhe estatuto mais estável, mais definitivo, mais bem ofertado ao discurso - poder-se-á responder dizendo que o próprio conceito de natureza humana $\mathrm{e}$ a maneira como ele funcionava excluíam que houvesse uma ciência clássica do homem. (2000, p. 424).

Vejamos com um pouco mais de minúcia essa condição do homem. Naquele período, portanto, assistimos sua ausência no interior do movimento científico, sendo relegado seu estudo à esfera metafísica. A esse respeito, Foucault (1987) afirma que as chamadas "ciências humanas" não receberam um domínio já delimitado, muito menos desbravado, em que elas precisassem, no século XVIII, elaborar conceitos enfim científicos e métodos positivos. A verdade é que o século XVIII não organizou um espaço, sob o nome de homem ou natureza, que demandasse a tarefa de cobrir e analisar, em suma, segundo o filósofo francês,

O campo epistemológico que percorrem as ciências humanas não foi prescrito de antemão: nenhuma filosofia, nenhuma opção política ou moral, nenhuma ciência empírica, qualquer que fosse, 
nenhuma observação do corpo humano, nenhuma análise da sensação, da imaginação ou das paixões, jamais encontrou, nos séculos XVII e XVIII, alguma coisa como o homem; pois o homem não existia (assim como a vida, a linguagem e o trabalho); e as ciências humanas não apareceram quando, sob o efeito de algum racionalismo premente, de algum problema científico não-resolvido, de algum interesse prático, decidiu-se fazer passar o homem (por bem ou por mal, e com maior ou menor êxito) para o campo dos objetos científicos [...] (p. $361 / 362$ ).

O "cenário científico", a partir dessa realidade, provém das profundas diferenças entre a ciência e a filosofia, acarretando, em última instância, na impossibilidade de superação da oposição entre sujeito e objeto e, finalmente, na reconsideração da questão do ser e do saber. Debruçados sobre essa questão é possível estabelecer, de um lado, uma ontologia cientificista, sustentando um ser objetivo envolto em uma condição universalista, que obstaculiza qualquer estudo do sujeito implicado nos fenômenos problematizados; e, de outro lado, um subjetivismo filosófico, também impeditivo de criar qualquer liame do sujeito com a abordagem científica objetiva das ciências. O trabalho de Lima (2013) traz grande contribuição ao nosso estudo quando assevera que

\begin{abstract}
O ser que a ciência sustenta é um ser dado segundo uma ontologia objetiva, pretensamente sustentada em leis universais, tendo as ciências da natureza (sobretudo a física) como medida do ser. Desprovido de operacionalidade, o ser reclamado pela filosofia é um ser subjetivo atrelado aos desígnios da alma e engessado por uma consciência de si, uma substância autossuficiente emergida com a metafísica. (p. 44)
\end{abstract}

Conforme já apontado anteriormente, o pacto iluminista entre a ciência e a igreja definiu à primeira o encargo das questões objetivas e à segunda, sob os cuidados da filosofia, os temas relacionados ao sujeito. Esta conduta induziu à ampla aceitação do objeto científico como verdade absoluta e irrefutável, tornandoo o único caminho válido para o conhecimento da realidade, enquanto às questões do sujeito são completamente ocultadas. Se o estudo dos fatos concretos em sua objetividade ficou à cargo da ciência, restou à filosofia o quinhão incerto e nebuloso da metafísica.

A chegada até esse momento de reflexão impele que dediquemos atenção ao valor das representações, apresentadas em diferentes momentos, consistem em entreposto entre o conhecimento e o real. Lefebvre (1981) levanta profundas 
discussões em torno deste conceito e nos traz importantes subsídios teóricos, inicialmente ao apontar que a filosofia moderna, desde Kant, não a entende nem como a verdade nem como o erro, nem como presença nem como ausência, nem observação nem produção. Os filósofos modernos se propuseram a transcender a representação pelo conhecimento, ou melhor, "pelo contrário, mostraram que o conhecimento não pode realizar esta operação; o que limita o conhecimento às suas representações e suas críticas" (p. 15).

De início é importante destacar, com base numa perspectiva idealista, que o saber não tem nada de absoluto ou de incondicional, mas consiste em uma vasta metáfora - como as já anunciadas fórmulas gravitacionais de Newton ou da relatividade de Einstein, que certamente não representaram o real físico (LEFEBVRE, 1981). Sem o intuito de nos aprofundarmos num debate filosófico entre a teoria idealista e o pensamento materialista, afirmamos, em acordo ao pensamento de Lefebvre (idem), que as representações não são apenas impostas de fora aos sujeitos e às consciências individuais, mas elas "também vêm de dentro, [são] contemporâneas da constituição do sujeito, tanto na história de cada indivíduo como na gênese do individuo em escala social" (p. 20). Hegel, cujo pensamento ainda será abordado, apresentou uma teoria que colocava as representações como uma etapa, um nível, um momento do conhecimento, assim seria preciso passar por elas para sair delas e as superar, todavia "a reflexão pode sempre voltar a cair nesse nível médio (mediador) entre o sensível e a abstração verdadeira, conceito e ideia (LEFEBVRE, 1981. p. 21). Deste modo, segundo Lefebvre, há uma falta de confrontação entre os diversos e opostos pensamentos, que, por conseguinte, se degradam nas representações. Não obstante,

Os pensamentos, ou seja, as determinações já relacionadas e opostas, em sua relação, caem na exterioridade do espaço e do tempo, em outras palavras na esfera da representação. A identidade formal erige então como lei e os termos contraditórios se mantém um fora do outro, numa justaposição e sucessão. A contradição se torna ininteligível, o absurdo; o pensamento se isola numa negação abstrata, de tal modo que morre a alma dialética, fonte de movimento (Ibidem, tradução livre).

De fato, o ser e o cognoscente não coincidem. Há uma distância, uma separação. Esta distância também separa o pensamento do ser, o que dificulta a definição entre o verdadeiro e o falso, bem como a mediação da imediação, "o 
sujeito do objeto, a vida espontânea da vida reflexiva, o humano da animalidade, a linguagem do real, o espírito do corpo, o desejo da coisa, o consciente do inconsciente $[. .].[\mathrm{e}]$ a presença da ausência” (Ibidem).

Cientes desta distância entendemos, sustentados pelo supracitado pensador francês, que o signo e a significação "ao nível da palavra se desprendem das coisas e do conhecimento em geral para retornarem autônomos", neste sentido "o signo é a representação de uma representação" (Idem. p. 23), ou seja, o único conteúdo do representante é o que representa e sua própria relação com o representado. Portanto, "o signo e suas concatenações são transparentes, inteligíveis por si e para si" (ibidem). Repleta tanto de conteúdo, como de materialidade e sociabilidade, a representação deixa de ser um problema e "se dissolve no signo, unidade de dois termos e de duas faces, o significante e o significado, o representante e o representado" (ibidem).

Os filósofos, assim como os poetas e outros, teorizaram a representação ao mesmo tempo em que queriam transcende-la, colocando o mundo moderno em meio a uma contradição cada vez mais manifesta entre, de um lado, a abundância de representações e sua utilização descontrolada; e, por outro lado, o esgotamento das representações, seu desgaste, seu esforço de renovação e, ao mesmo tempo, esforço de abolição, seja mais para cá (natureza, intuição) seja mais para lá (metafísica, misticismo etc.) (ibidem). Outro filósofo francês, Foucault, apresenta a crítica kantiana como marco importante da modernidade por interrogar a representação em seus limites, inaugurando um acontecimento na cultura europeia que é contemporâneo ao fim do século XVIII: "a retirada do saber e do pensamento para fora do espaço da representação" (p. 257). Nesse sentido, a crítica ressalta a dimensão metafísica que a filosofia oitocentista quisera reduzir à simples análise da representação. No entanto, permitiu que uma outra metafísica, dedicada à interrogação, fora da representação, de tudo o que constitui sua fonte e origem. Abriu-se caminho, dessa maneira, às "filosofias da Vida, da Vontade, da Palavra, que o século XIX vai desenvolver na esteira da crítica” (p. 258). 


\subsubsection{Emerge, enfim, um outro paradigma científico}

Com base nessa situação diversos pensadores procuraram aparar estas arestas e um caso nos é bastante importante: Immanuel Kant. Não é demais ressaltar que não figura em nosso escopo de pesquisa realizar uma vasta investigação sobre a produção teórica deste filósofo, mas apenas resgatar importantes aspectos de seu pensamento para sustentar nosso estudo. Desse modo, é de grande relevância refletirmos sobre a consagração dos modelos lógico-matemáticos na sistematização da ciência e a existência de uma dimensão inacessível ao conhecimento humano objetivo, idealizações que posicionam o ser no interior de uma densa névoa fenomênica intransponível com o repertório científico oportunizado.

É sabido que ao longo de todo o século XVII o conhecimento esteve ancorado numa mathêsis, detentora do poder ordenador e com função fundante nas disciplinas matemáticas, bem como exercendo papel de formação de domínios diversos, e puramente empíricos como a gramática geral, a história natural e a análise das riquezas (FOUCAULT, 1987). Não obstante, Kant conjuga em sua filosofia as considerações do racionalismo e empirismo, vertente denominada criticismo e que tem como base duas categorias do entendimento: a razão e a sensibilidade (BITETI, 2007). Referenciado por Platão - mundo sensível e mundo inteligível - Kant entende que a razão precede e organiza a sensibilidade, ou seja, o conhecimento do mundo significa dotá-lo de uma ordem, mas as sensações, os fenômenos são completamente transformados pelo sujeito que conhece" e isto se deve ao fato de que "nosso espírito, incapaz de sair de si mesmo, encontra nas coisas tão-somente aquilo que nelas pôs: sua marca, a 'forma' conferida ao conteúdo ou matéria sensível [...] do conhecimento" (LEFEBVRE, 1981. p. 59).

De acordo com seu pensamento e sua crítica às representações, a ciência estabelece uma busca incessante pelo todo, pelo geral, almejando atingir o absoluto pelo objeto, pensamento que Kant (Ebook Kindle, sem datação) coloca nos seguintes termos: "devo proceder sempre de maneira que eu possa querer também que a minha máxima se torne uma lei universal" (p. 18). O filósofo alemão, aliás, é de grande valia neste debate justamente por admitir que os conhecimentos advêm efetivamente da experiência, asserção complementada por Feyerabend (1977) que, ao definir Aristóteles como um empirista, está atribuindo grande valor à observação direta e argumentando que "a experiência é de grande importância para o 
conhecimento porque, em circunstâncias normais, as percepções do observador contêm formas idênticas às que residem no objeto" (p. 232).

Além do grande valor atribuído à experiência, Kant, em sua filosofia, também é responsável por realizar a crítica e a negação da ontologia clássica (grega). Importava para o pensamento kantiano indagar pela cientificidade do saber metafísico porquanto a matemática e a física alcançaram a segurança da ciência. A matemática, desde os gregos, pavimentou seu edifício com os fundamentos da ciência, já os físicos, revolucionando sua forma de pensar, compreenderam que se deve procurar na natureza o que lá a razão coloca e, a partir disso, depreender o que por si só não seria possível. A razão figura, dessa forma, como o juiz que pede à natureza que responda (FEYERABEND, 1977).

Nesse sentido, para Kant é possível distinguir a realidade em dois aspectos, o natural ou físico, estudado pela ciência, e o humano ou metafísico, objeto da filosofia. Kant separa a natureza do pensamento e de seu funcionamento, colocando o objeto como produto do pensamento ativo, cujo motor é uma atividade inteiramente interior e de origem misteriosa (metafísica), em nosso espírito. É a partir deste posicionamento que Kant entende as verdades científicas, referentes aos fenômenos, com o alcance restrito ao conhecimento humano, significando, segundo Lefebvre (1981), que cada representação de um objeto é acompanhada de uma representação privilegiada, central, o sujeito (o "eu penso").

Kant investiga, então, a possibilidade de adoção do modelo de saber matemático e da física pela metafísica, considerando ser este o único caminho de elevá-la à ciência. A metafísica, em seu cerne, pensava que o nosso conhecimento deveria ser regulado pelos objetos e que através da razão poderíamos contemplar a verdade do objeto, ou seja, sua essência. Na concepção kantiana isso impedia de se descobrir a priori, mediante conceitos, algo que ampliasse nosso conhecimento, daí a importância de redefinir as tarefas da metafísica.

Por conseguinte, há, no pensamento de Kant, um domínio de verdades absolutas, eternas - "numenais", a coisa em si -, inacessível em sua dimensão objetiva já que o conhecimento está limitado à esfera fenomênica das coisas (KANT, Ebook Kindle, sem datação), tornando ainda mais profunda a cisão entre sujeito e objeto. É dessa forma que o pensador alemão afirma não podermos 
conhecer o real em si, apesar da faculdade da razão que tenta ultrapassar os limites da experiência, ou seja, a razão quer pensar o real em si, mas nada corresponde objetivamente ao conhecimento por ela formulado. Destarte, se estabelece no interior do pensamento kantiano uma dualidade entre pensamento e real, entre sujeito e objeto, permitindo inferir que no idealismo de Kant há a consideração de uma "deficiência" do pensamento, ou melhor, na razão cognoscente, nas categorias do pensar, enquanto o objeto está isento de contradições.

Não obstante, Kant atribui à metafísica ${ }^{32}$ a capacidade de investigar os objetos imateriais, passivos de serem conhecidos pela razão somente a priori, sem relação com os dados do mundo sensível e alheios às categorias da ciência (BITETI, 2007). O sujeito não detém uma substância e, assim, mundo sensível e mundo perceptível são compostos por representações, e "esta palavra não designa somente os 'objetos' mentais mas também os que percebem os sentidos" (idem. p. 29). O trabalho de Kant tinha como orientação, como se vê, saber as condições e os limites possíveis de um conhecimento puro da natureza, cujo alcance se daria através da limitação do conhecimento às coisas porquanto "a experiência ensina-me, certamente, o que existe e como existe, mas nunca que isso deve existir necessariamente assim e não de outro modo. Por conseguinte, ela jamais pode fazer conhecer a natureza das coisas em si mesmas" (KANT, 1988. p. 66). Ou seja, a razão é prisioneira da contradição, o que a impede de elaborar um conceito adequado do real, bem como que a ciência realize o seu grande intento: pensar o real tal como ele é.

De acordo com esta constatação, o filósofo alemão busca evidenciar a validade objetiva do conhecimento científico, obtido através de um juízo que ocorre ora no âmbito da sensibilidade, ora no campo da percepção. Em suma, o juízo pode ser representado de duas formas: analítico, quando corresponde a aspectos estruturais do sujeito; ou sintético, quando faz referência a adjetivações do sujeito. Além destas duas possibilidades, um juízo pode ser um a priori, caso em que

\footnotetext{
${ }^{32}$ Quanto ao método da metafísica, Kant entende que: " Sua marcha, é, no princípio, dogmática; quer dizer, ela enceta confiadamente o seu trabalho sem ter provas na potência ou impotência de nossa razão para tão grande empresa" (KANT, Edição do Kindle, sem datação). Neste sentido, é imperativo saber como na metafísica o entendimento, abandonando o terreno da experiência, atinge seu conhecimento a priori e qual a sua extensão e limites, e o valor que possuem. Kant objetiva estabelecer uma reorganização da metafísica, o que é possível à razão, pois, "[...] a razão pura especulativa tem em si mesma a particularidade de medir exatamente a sua capacidade em função dos diversos modos como escolhe para o pensar [...]" (KANT, Edição do Kindle sem datação).
} 
independe da experiência, formando um juízo analítico; e pode ser um a posteriori, quando é decorrente da experiência sensível, indicando um juízo sintético. É fundamental destacar que as únicas exceções são o tempo e o espaço, considerados juízos sintéticos a priori $^{33}$.

Nestes termos estrutura-se que todo conhecimento é um dado intuído a posteriori, uma representação, um fenômeno, obtido através da sensibilidade, mas a sua organização reside em um a priori no sujeito. O sujeito cognoscente, seguindo este raciocínio, é transformado em sujeito restrito em seu poder de ação e não mais exclusivamente contemplativo do mundo natural e na produção do conhecimento porquanto ele participa da constituição da natureza enquanto processo cognitivo. Se a sensibilidade é uma faculdade passiva do conhecimento, o entendimento é uma faculdade ativa, responsável por ligar as representações ofertadas pela sensibilidade.

Dedicaremos especial atenção, a partir deste momento e após esta sucinta caracterização da filosofia kantiana, à análise desenvolvida por Foucault (1987) às transformações ocorridas no campo científico em virtude da ascensão da crítica kantiana e de suas interrogações às representações. Ocorreu que no final do século XVIII desenvolveu-se a dissolução desse campo homogêneo de representações ordenáveis, fazendo emergir, correlativamente, duas novas formas de pensamento: a que indaga as condições de uma relação entre as representações ao lado da que as torna em geral possíveis (idem). Esta situação evidencia um campo transcendental

Onde o sujeito, que jamais é dado à experiência (pois não é empírico), mas que é finito (pois não tem intuição intelectual) determina na sua relação com um objeto [...] todas as condições formais à experiência em geral; é a análise do sujeito transcendental que extrai o fundamento de uma síntese possível entre as representações. (p. 258)

\footnotetext{
${ }^{33}$ É importante registrar que esta consideração de Kant acerca do tempo e do espaço encontra fundamento no conceito de força newtoniano, entendido como responsáveis por mover a natureza e, consequentemente, são o princípio de todo o conhecimento. Gomes (1996) nos mostra que para compreender a noção de força organizada dentro de um sistema abstrato, Newton definiu claramente pela primeira vez as categorias de espaço e de tempo absolutos; assim, a "distinção newtoniana entre o espaço absoluto e o lugar, definido como uma parte do espaço que um corpo ocupa, está na origem do espaço considerado como categoria a priori kantiana" (p. 74) porquanto no raciocínio de Newton existe um espaço anterior, desprovido de qualquer relação com o exterior, e um espaço relativo, ocupado por corpos e objeto da experiência sensível.
} 
As "novidades" apontadas por Foucault remetem diretamente à emergência simultânea de um tema transcendental e de campos empíricos novos: a potência de trabalho, a força da vida, o poder de falar. Vejamos uma pouco melhor essa importante questão. Estas formas transcendentais extrapolam os limites de nossa experiência e vêm até nossas representações solicitando a tarefa do conhecimento, tornando possível o conhecimento objetivo dos seres vivos, das leis da produção, das formas da linguagem ${ }^{34}$. A dimensão transcendental, que se abre conjuntamente com uma outra forma de interrogar as condições de uma relação entre as representações, coloca como fundamento de unidade esses objetos jamais objetiváveis, essas representações jamais inteiramente representáveis, essas visibilidades ao mesmo tempo manifestas e invisíveis, essas realidades que estão em recuo na mesma medida em que são fundadoras daquilo que se oferece e se adianta até nós, ou seja, o trabalho, a vida e a linguagem (ibidem). O pensamento do filósofo francês encontra ressonância em outro reconhecido pensador francófono, defensor da ideia de que mediante a verdade social (natureza, trabalho, técnicas e conhecimento) as representações se desvanecem, fazendo com que a crítica de Kant fosse recuperada posteriormente por Marx em seus trabalhos sobre o modo de reprodução capitalista (LEFEBVRE, 1981). Ainda não é chegado o momento de tratarmos desta discussão, mas já é possível entrever o ponto que almejamos atingir.

Portanto, para melhor organizar nossa explanação, há uma ontologia cientificista balizando um ser objetivo encarado universalmente e que impede as ciências de tomá-lo nos fenômenos em que está implicado; e um subjetivismo filosófico avistando um sujeito contemplativo e transcendental, também impedido de relacionar o sujeito com a abordagem objetiva das ciências. Ou universalmente concebido e tendo as ciências da natureza, com seus receituários matemáticos, como única forma de medida, ou ausente de ação, vinculado ao chamado da alma e a uma substância oculta metafísica, como sugere a filosofia, o fato é que o ser jaz

\footnotetext{
${ }^{34}$ Deleuze, em uma obra exclusivamente voltada ao pensamento foucaultiano (2006), destaca que a mutação ocorrida no final do século XVIII consiste no fato de "as forças do homem entram em relação com novas forças de fora, que são as forças de finitude. Estas forças são a Vida, o Trabalho e a Linguagem: tripla raiz da finitude, que vai provocar o nascimento da biologia, da economia política e da linguística" (p. 135). A contribuição de Deleuze reforça a necessidade de entendermos o posicionamento de Foucault a partir da insistência de ver o homem enfrentando as forças de finitude que vêm de fora, ou seja, é fora de si que o homem deve se chocar com a finitude.
} 
em um terreno sombrio entre sujeito e objeto, permanecendo indefinidamente como questão gnosiológica e, ao mesmo tempo, ontológica.

Ademais, toda a teorização de Kant colocou em xeque os fundamentos que alicerçavam o saber e que garantiam com relativa uniformidade a distinção entre ciência (avalizava os fatos concretos) e a metafisica (dedicada à interioridade individual). Foucault assevera que a partir de Kant

O problema é inteiramente diverso; o saber não pode mais desenvolver-se sobre o fundo unificado e unificador de uma máthêsis. Por um lado, coloca-se o problema das relações entre o campo formal e o campo transcendental [...]; e, por outro lado, coloca-se o problema das relações entre o domínio da empiricidade e o fundamento transcendental do conhecimento. (p. 262)

Deste modo é possível perceber que para Kant nosso conhecimento se refere apenas aos fenômenos e não às "coisas em si", pois os princípios da razão pura têm como limites a sensibilidade, de modo que não podemos conhecer o suprassensível, ou essência, como pretendia a metafísica clássica. Ademais, demonstrará que espaço e tempo são formas da intuição sensível, ou seja, consistem em condição da existência das coisas enquanto fenômenos e que só possuímos conceitos do entendimento, ou seja, juízo, conhecimento, quando alcançarmos a intuição correspondente a estes conceitos. Não obstante, é possível inferir que não podemos conhecer os objetos como "coisa em si", mas apenas como objetos de intuição sensível (LEFEBVRE, 1981), tornando a totalidade incognoscível, pois a separação entre a "essência" e o "fenômeno", limita o conhecimento das coisas à dimensão fenomênica. Neste contexto, sempre que a razão tenta pensar a totalidade, ou seja, todas as vezes que a razão pura se fixar sobre raciocínios dialéticos, cairá em contradição.

Após toda esta exposição, é colocada em evidência a impossibilidade da ontologia enquanto ciência no pensamento kantiano. A metafísica exclui a contradição do real e do pensamento sobre o real, nos distanciando do real e do pensamento sobre o real, e nos levando a pensar o real essencialmente como substância imóvel, portanto, sem processo, sem contradição. Outrossim, o pensamento kantiano ao excluir a contradição do pensamento sobre o real, nega o caráter ontológico do conhecimento, nega que a razão seja capaz de dar conta do 
real e limita o campo do conhecimento ao fenomênico, ao aparente, ao não contraditório.

Portanto, de acordo com o pensamento de Foucault, com base em sua arqueologia, o final do século XVIII assiste a profundas rupturas que reconfiguram radicalmente o campo científico ${ }^{35}$, com destaque, em nosso entendimento, para o “espaço geral do saber” que não é mais pautado pelas identidades e diferenças, pelas caracterizações universais, por uma taxonomia geral, por uma máthêsis do nãomensurável, mas se estabelece um espaço feito de organizações, isto é,

De relações internas entre elementos, cujo conjunto assegura uma função; mostrará que essas organizações são descontínuas, que não formam, pois, um quadro de simultaneidades sem rupturas, mas que algumas são do mesmo nível enquanto outras traçam séries ou sequencias lineares. (1987. p. 232)

Toda esta fundamentação teórica não estaria devidamente desenvolvida se desconsiderássemos a contribuição de Marx ao longo do processo de construção do edifício científico moderno, especialmente no caso da Geografia. Neste sentido, o próximo item é dedicado às proposições ontológicas de Marx, entendidas como centrais para a crítica do currículo escolar desenvolvida posteriormente.

\subsection{A crítica ontológica de Marx}

Já nos encaminhando para o final deste capítulo faz-se mister assinalar a indagação trazida por Marx em seus Manuscritos: "o que fazer diante da dialética hegeliana?" (2008. p. 115 grifo do autor $)^{36}$. O próprio Marx ressaltara que, ao

\footnotetext{
${ }^{35}$ Foucault (1987) ao dissertar sobre este novo momento da ciência é bastante claro ao afirmar que "a constituição de tantas ciências positivas, o aparecimento da literatura, a volta da filosofia sobre o seu próprio devir, a emergência da história ao mesmo tempo como saber e como modo de ser da empiricidade, não são mais do que sinais de uma ruptura profunda" (p. 235).

${ }^{36} \mathrm{E}$ importante ressaltar que optamos por não realizar a discussão em torno da dialética hegeliana para não prolongarmos ainda mais este árido capítulo e para não nos distanciarmos de nossos objetivos porquanto já apresentamos brevemente este tema na introdução da pesquisa. Gostaríamos apenas de ressaltar, de forma complementar, que a dialética emerge como mecanismo que permite a compreensão da constituição do ser através do processo da verdade, cujo primeiro momento é a tese, seguido pela antítese e, finalmente, pela síntese. De fato, o que se busca é a superação da contradição em direção a uma unidade final, o que somente é possível com a negação da negação, ou seja, a síntese - aufhebung - substitui a contradição e faz da verdade o resultado de um processo e reúne em si todo este processo. Desse modo, em suma, a dialética hegeliana busca encontrar na síntese a Ideia (a essência), que é onde se realiza o processo e essa realização contém em si o processo, ou seja, "a Ideia já está presente em todo o processo, e o processo inclui em si as oposições, os dualismos, as contradições. Por isso, o mistério todo da Ideia é que ela não está além do processo, em qualquer coisa como um outro mundo; muito mais, a Ideia é uma presença dentro do próprio
} 
contrário do que pensaram os próprios jovens hegelianos, a dialética em Hegel é apenas formal e é justamente por se prenderem em demasia à crítica do conteúdo da filosofia hegeliana que os alemães não se aperceberam reclusos no interior do idealismo de Hegel que acreditavam combater.

Por conseguinte, cabe ressaltar que a interrogação de Marx (2008) parece conter também um quê de surpresa sobretudo após a contribuição teórica de Feuerbach a quem o filósofo chama de "verdadeiro triunfador (Überwinder) da velha filosofia" e o avalia como o "único que tem para com a dialética hegeliana um comportamento sério, crítico e [o único] que fez verdadeiras descobertas nesse domínio" (p. 117). Para Marx, o trabalho exitoso de Feuerbach reside na descoberta de três pontos principais:

1) a prova de que a filosofia não é outra coisa senão a religião trazida para o pensamento e conduzida pensada[mente]; portanto, deve ser igualmente condenada [...];

2) A fundação do verdadeiro materialismo e da ciência real, na medida que Feuerbach toma, do mesmo modo, a relação social, a do 'homem com o homem', como princípio fundamental da teoria;

3) Na medida em que ele confronta à negação da negação, que afirma ser o absolutamente positivo, o positivo que descansa sobre si mesmo e positivamente se funda sobre si próprio. (Ibidem)

Nestes termos Feuerbach, segundo Marx (2008), procura esclarecer que Hegel, de fato, parte da religião para suprassumi-la no momento seguinte e, finalmente, restabelecê-la, ou seja, a negação da negação estaria restrita a uma contradição da filosofia, que, após negar a religião, tornou a afirmá-la. Por conseguinte, a afirmação da fillosofia estaria baseada em terreno instável em virtude de sua posição não se fundar sobre si mesma, mas na negação da religião. Marx é bastante assertivo ao enfatizar que a filosofia, para Hegel, não é um provar-se a si mediante sua própria existência, mas tem sua existência em função da negação da religião, ou seja, sua posição seria uma afirmação da "não-religião", ou seja, a filosofia consistiria apenas na passagem da religião de sua pressuposição para sua posição, evidenciando que é a religião que se autoafirma através da filosofia e não o contrário (VIEIRA, 2018). A crítica marxiana é bastante contundente ao cerne da 
proposição filosófica de Hegel quando Marx aborda os momentos em torno da Aufhebung e afirma que esse processo

\begin{abstract}
Implica que o homem consciente de si, na medida em que reconheceu e suprassumiu (aufhob) o mundo espiritual - ou a existência espiritual universal de seu mundo - enquanto autoexteriorização, confirma-o novamente, contudo, nesta figura exteriorizada e o toma como seu verdadeiro modo de existência, restaura-o, finge estar, em seu ser-outro enquanto tal, junto de si; por conseguinte depois da suprassunção (Aufhebung), por exemplo, da religião, depois do reconhecimento da religião como um produto da auto-exteriorização, encontra-se, não obstante, confirmado na religião como religião. Aqui está a raiz do falso positivismo de Hegel ou de seu criticismo apenas aparente o que Feuerbach indicou como o pôr (Setzen), o negar e o restaurar da religião ou teologia, o que é, porém de se apreender de modo mais universal. [Em Hegel] a razão está junto de si na não razão (Unvernunft) enquanto não-razão. O homem que reconheceu levar no direito, na política etc., uma vida exteriorizada, leva nesta vida exteriorizada, enquanto tal, sua verdadeira [vida] humana. (MARX, 2008, p. 129/130 grifos do autor).
\end{abstract}

De acordo com Vieira (2018), esta proposição de Marx encontra balizas teóricas consistentes para destacar, segundo a própria concepção de filósofo alemão, dois equívocos básicos de Hegel, a partir de sua Fenomenologia, lugar de nascimento da filosofia hegeliana. O primeiro seria a introdução do conceito no movimento da história, mas sua realização se deu em um movimento da história especulativo, pois ele "somente encontrou a expressão abstrata, lógica, especulativa para o movimento da história, a história ainda não efetiva do homem enquanto um sujeito pressuposto" (2008. p. 119), sinalizando que Hegel não vislumbrou a história efetiva do homem, a história como história do homem, ou melhor, a história como ato de produção do homem. Esta reflexão resulta da compreensão de que todo pensar em Hegel é especulação e a história, por conseguinte, não é a história do ser humano, consistindo apenas em pensamento separado entre ser humano e sua relação concreta com a natureza, ou seja, é o "pensar exteriorizado, que por essa razão faz abstração da natureza e do ser humano efetivo; o pensar abstrato" (p. 120 grifos do autor). O segundo equívoco de Hegel reside no movimento de atribuir como verdadeira essência humana o espírito lógico, especulativo, distanciado da efetividade do homem, permitindo que a sensibilidade e a religião figurassem não como produtos do homem, mas apenas do pensamento. É na Fenomenologia que Marx identifica como o pensamento hegeliano atrela o estranhamento do homem à 
religião, ao Estado, à vida civil e, ao mesmo tempo, conserva o homem estranhado na medida em que apenas no pensar que este se apropria de suas próprias forças humanas tornadas objetos estranhos, ou melhor,

A apropriação das forças essenciais humanas tornadas objetos, e objetos estranhos é, pois, primeiramente, apenas uma apropriação que se sucede na consciência, no puro pensar, isto é, na abstração, a apropriação desses objetos como pensamentos $e$ movimentos do pensamento, razão pela qual, já na Fenomenologia - apesar do seu aspecto absolutamente negativo e crítico, e apesar da crítica efetivamente encerrada nela, crítica frequentemente antecipadora do desenvolvimento ulterior - já está latente enquanto gérmen, enquanto potência, como um mistério, o positivismo acrítico das obras hegelianas posteriores [...]. A "Fenomenologia" é, por isso, a crítica oculta (verbogene), em si mesma ainda obscura e mistificadora; mas na medida em que ela retém (hält fest) o estranhamento do homem - ainda que também este último apareça apenas na figura do espírito -, encontram-se nela ocultos todos os elementos da crítica, muitas vezes preparados e elaborados de modo que suplantam largamente o ponto de vista hegeliano. (2008, p. 122 grifos do autor)

Asseverar, a partir deste posicionamento, que, para Marx, Hegel opera uma mistificação da realidade ao mesmo tempo em que realiza a sua crítica é constatar como o idealista alemão ao promover o edifício dialético da "negação da negação" efetiva não a posição da verdadeira essência, mas a posição da negação da essência estranhada como essência objetiva. O aufhebung, em Hegel, consiste em uma apreensão filosófica da essência estranhada, situação que coloca também a ontologia e a gnosiologia na condição de um par em plena abstração ao lidarem não com a essência do homem em suas determinações particulares, mas com constructos humanos (a sociedade civil, o Estado, a história), ou seja, a essência, segundo esta perspectiva, residiria no movimento desses diversos momentos do pensar humano. Marx corrobora essa perspectiva analítica quando escreve que

$\mathrm{Na}$ sua existência efetiva, sua essência móvel está oculta. Manifesta-se, revela-se, em primeiro lugar, no pensar, na filosofia, e por isso minha verdadeira existência religiosa é minha existência (Dasein) filosófico-religiosa, minha verdadeira existência política é minha existência filosófico-jurídica, minha verdadeira existência natural é a filosófico-natural, minha verdadeira existência artística é a existência filosófico-artística, minha verdadeira existência humana [é a] minha existência filosófica. (Idem, p. 130/131) 
As críticas de Marx a Hegel compõem, inegavelmente, um importante momento para o avanço do conhecimento científico. A partir destes posicionamentos críticos de Marx e cientes de que a crítica precisa ser necessariamente ontológica, entendemos, como assinalamos no início deste capítulo, estar mergulhados numa espécie de ausência de crítica ontológica à sociedade, o que resultou, segundo Zizek (2012), na consagração das "coordenadas ideológicas hegemônicas" (em tradução livre), ou seja, uma ontologia de um mundo insuperável ("what can one do against the global capital?” ou em tradução livre, "o que alguém pode fazer contra o capital global?”), e que torna sem sentido qualquer luta política. Nesse sentido, retomando uma consideração de Lukács, a prática dos seres humanos é teleológica, envolvendo uma consciência que compreende as circunstâncias do mundo real. Todavia para que essa prática seja finalística, ou seja, para que o agir humano encontre sentido é necessário conhecer o mínimo das coisas, seus nexos e propriedades, com o fito de atingir aquilo que planeja. É por essa razão que a "verdade é absolutamente central na práxis humana" (DUAYER, 2012. p. 112).

As palavras de Zizek, em discurso proferido no movimento Occupy Wall Street, em 2011, podem ser iluminadoras:

\begin{abstract}
Eles dirão que vocês estão sonhando, mas os verdadeiros sonhadores são os que pensam que as coisas podem continuar sendo o que são por um tempo indefinido, assim como ocorre com as mudanças cosméticas. Nós não estamos sonhando; nós acordamos de um sonho que está se transformando em pesadelo. Não estamos destruindo nada; somos apenas testemunhas de como o sistema está gradualmente destruindo a si próprio. Todos nós conhecemos a cena clássica dos desenhos animados: o gato chega à beira do precipício e continua caminhando, ignorando o fato de que não há chão sob suas patas; ele só começa a cair quando olha para baixo e vê o abismo. O que estamos fazendo é simplesmente levar os que estão no poder a olhar para baixo...
\end{abstract}

A interpretação do discurso de Zizek nos mostra sua preocupação em estruturar uma oposição ao "sistema", uma luta contra-hegemônica que traga sentido aos ideais de revolução e transformação radicais da sociedade, o que só é possível com o devido resgate de uma crítica ontológica. Entendemos estar alinhados com este posicionamento em favor de uma necessária retomada da crítica ontológica (marxista) para a organização de uma contra-hegemonia de que nos 
falam diferentes autores, de diversas formas. É o caso de Vaneigem (1967) ao afirmar que

O erro dos filósofos foi construir uma ontologia e uma idéia de homem eterno (imutável) com base em algo que não passava de um acidente social, uma necessidade contingente. A história se esforça para liquidar a apropriação privada desde que ela deixou de responder às condições que lhe deram origem. Mas o erro, mantido metafisicamente pelos filósofos, age em proveito dos senhores, da "eterna" minoria dominante. (p. 72)

A "eterna" minoria hegemônica também foi abordada de forma bastante incisiva pela interpretação crítica do marxismo elaborada por Lefebvre, que, ao seu modo, entende o capitalismo como uma forma de produção que generaliza a troca, colocando em circulação o sentimento, as ideias, os homens.

É interessante coadunar a valiosa contribuição de Harvey (1976), que ao abordar a elaboração de uma teoria revolucionária e contrarrevolucionária na Geografia, é enfático ao asseverar que "uma teoria revolucionária na qual se baseia um novo paradigma só ganhará aceitação geral se a natureza das relações sociais incluída na teoria é realizada no mundo real” (p. 4, tradução livre). A premissa apontada pelo supracitado estudioso é fundamental e torna ainda mais radical a necessidade de recuperação de preceitos ontológicos originais que sustentem o desenvolvimento de uma verdadeira luta contra-hegemônica, sob o risco de assistirmos de pés e mãos atados a consolidação de uma teoria contrarrevolucionária, ou seja, de "uma teoria proposta deliberadamente para lidar com uma teoria revolucionária, a fim de evitar as mudanças sociais que ameaçam a aceitação geral da teoria revolucionária, seja por adaptação ou subversão" (ibidem).

Não é de outra forma, por conseguinte, que a (re)organização de um movimento contra-hegemônico carece da apreensão da dinâmica histórica para adquirir validade e é em decorrência deste fato que emerge a importância de um conhecimento objetivo e verdadeiro. Ser e conhecimento (ontologia e gnosiologia) consistem em parâmetros fundamentais para quaisquer movimentos de contestação hegemônica, justamente porque podem subsidiar a crítica aos pressupostos estruturais do modo de produção capitalista ${ }^{37}$, uma vez que a prática humana é,

\footnotetext{
${ }^{37}$ Acreditamos ainda ser conveniente ressaltar que nossa compreensão do modo de produção capitalista está atrelada às ideias desenvolvidas por Postone (2014) acerca do núcleo fundamental do capital. Nesse sentido, o autor canadense, também intentando concertar uma reconceituação da
} 
como sabemos pelas formulações lukacsianas, teleológica, intencional e, em consequência, dependente de uma significação do mundo relativamente unitária, ou seja, a significação do mundo é o pressuposto básico das práticas teleológicas e que, por isso, precisa ser reconstruído. Ancorados pelo pensamento de Lukács (2013), compreendemos que

Hoje, quando o nível concreto de desenvolvimento das ciências tornaria objetivamente possível uma ontologia correta, é ainda mais evidente que esse fundamento da falsa consciência ontológica no campo científico e a sua influência espiritual se acha fundado nas necessidades sociais dominantes. Só para mencionar aquele de maior peso, a manipulação na economia se tornou fator decisivo para a reprodução do capitalismo atual e, a partir desse centro, irradiou-se para todos os campos da práxis social. Em seguida, essa tendência recebe apoio ulterior manifesto ou latente - por parte da religião. (p. 72)

Desta maneira é possível inferir que o modo de produção capitalista, reproduzido pelas práticas humanas teleológicas, supõe como condição sine qua non uma determinada ontologia que referenda tais práticas e, de acordo com nossas premissas investigativas, o espaço escolar é ambiente adequado ao seu desenvolvimento e aprimoramento. Não obstante, as lutas contra-hegemônicas precisam encontrar fundamentos em outra ontologia, uma ontologia crítica à primeira, o que, em nosso entender, implica uma outra crítica aos espaços escolares, de cunho ontológico, como temos tentado realizar. Duayer (2012) é bastante claro ao afirmar que a "crítica ontológica é condição necessária, ainda que não suficiente, para a emancipação das estruturas sociais estranhadas, opressoras, iníquas e infames" (p.125).

Estas premissas, também encaradas como objetivos em sentido amplo, indicam uma contraposição a alguns pressupostos da ciência moderna, uma reordenação da prática científica que nos é bastante caro. Em período anterior, reluzia a prioridade conferida ao sujeito na condução da investigação científica, ou

natureza da sociedade capitalista, conceitua o capitalismo "em termos de uma forma historicamente específica de interdependência social com um caráter impessoal e aparentemente objetivo. Essa forma de interdependência se realiza por intermédio de relações sociais constituídas por formas determinadas de prática social que, não obstante, se tornam quase independentes das pessoas engajadas nessas práticas. O resultado é uma forma nova e crescentemente abstrata de dominação, que sujeita as pessoas a imperativos e coerções estruturais impessoais que não podem ser adequadamente compreendidos em termos de dominação concreta (por exemplo, dominação pessoal ou de grupo), que também gera uma dinâmica histórica contínua" (p. 18). 
seja, o sujeito imputava ao seu "objeto" sua lógica e o enquadrava no formato científico vigente (NETTO, 2011). Esta perspectiva científica moderna foi confrontada por Marx, que ao criticar a centralidade do sujeito denunciava o abandono da prioridade ontológica do ser, da realidade objetiva, explicitando, com base naquilo que Lukács nos ensina, a necessária instauração de uma ontologia do ser social. Por conseguinte, é em comunhão com outros pensadores que atribuímos às reflexões de Marx um caráter radical e revolucionário, cujo sentido prima, antes de tudo, ontológico.

Estas considerações parecem encontrar bastante sentido quando, apoiados pelos estudos de Postone (2014) acerca do caráter historicamente dinâmico da sociedade capitalista, percebemos que o objeto central da crítica da economia política de Marx é a forma de sujeição geral radicada na condição de que as pessoas fazem a história, mas a fazem dentro de uma circunstância que as coage e as domina. Não obstante, seguindo a corrente teórica composta por Lukács, a crítica ontológica da sociedade capitalista realizada por Marx está assentada na crítica da centralidade do trabalho própria e específica dessa mesma sociedade. É relevante apresentar uma breve consideração sobre a categoria trabalho na filosofia de Lukács com o fito de agregar maior densidade teórica à nossa proposição ontológica e já sinalizar e fundamentar as discussões vindouras, porquanto tal fundamentação sedimenta as discussões sobre a problemática da educação.

Neste sentido, é válido afiançar que para Lukács (2013) a categoria trabalho consiste em uma atividade originária, detentora dos germes das demais determinações que constituem o ser social, todavia não seria correto limitar a vida social ao trabalho. Na realidade, esta identificação indica uma gradativa distinção da vida social "em uma multiplicidade de complexos heterogêneos se enraíza nesta atividade originária que é o trabalho" (TERTULIAN, 2009. p. 381). É o próprio Lukács quem escreve que a prioridade ontológica conferida ao trabalho

É antes de tudo, em termos genéticos, o ponto de partida para o tornar-se homem do homem, para a formação das suas faculdades, sendo que jamais se deve esquecer o domínio sobre si mesmo. Além do mais, o trabalho se apresenta, por um longo tempo, como o único âmbito desse desenvolvimento; todas as demais formas de atividade do homem, ligadas aos diversos valores, só se podem apresentar como autônomas depois que o trabalho atinge um nível relativamente elevado. (2012. p. 242/243) 
Por conseguinte, ainda segundo o pensador húngaro, é "no trabalho [que] estão contidas in nuce todas as determinações que, como veremos, constituem a essência do novo no ser social" (2013. p. 35). Lukács, ademais, ao investigar a gênese do ser social, atribui grande valor ao seu caráter histórico e defende o chamado "salto ontológico", que, na realidade, consiste numa ruptura na passagem de um nível do ser ao outro e tem no trabalho a sua principal via para o estabelecimento de uma vida especificamente humana. A partir destas constatações torna-se mais clara a ideia de que "a essência do trabalho humano consiste no fato de que, em primeiro lugar, ele nasce em meio à luta pela existência e, em segundo lugar, todos os seus estágios são produto de sua autoatividade" (ibidem). Portanto, inspirado em Marx, o supracitado pensador compreende a essência ontológica do trabalho no seu aspecto originário, na sua inter-relação entre a sociedade e a natureza, isto é, como condição perene da vida humana na relação com a natureza. Em suas palavras,

Se entendemos o trabalho no seu caráter originário - quer dizer, como produtor de valores de uso - como forma "eterna", que se mantém ao longo das mudanças das formações sociais, do metabolismo entre o homem (sociedade) e a natureza, fica claro que a intenção que determina o caráter da alternativa, embora desencadeada por necessidades sociais, está orientada para a transformação de objetos naturais. (LUKÁCS, 2013. p. 58)

Neste contexto, o trabalho adquire centralidade justamente por permitir desvendar o "complexo concreto da sociabilidade como forma de ser" (idem. p. 35), não significando, como nos adverte Tertulian (2009) uma "redução da vida social ao "paradigma do trabalho"” (p. 380). Na realidade, Lukács esclarece que o acento e realce conferido ao trabalho no processo da gênese do ser social se deve ao fato de que

Todas as outras categorias dessa forma de ser têm já, em essência, um caráter puramente social; suas propriedades e seus modos de operar somente se desdobram no ser social já constituído; quaisquer manifestações delas, ainda que sejam muito primitivas, pressupõem o salto como já acontecido. Somente o trabalho tem, como sua essência ontológica, um claro caráter de transição: ele é, essencialmente, uma inter-relação entre homem (sociedade) e natureza, tanto inorgânica (ferramenta, matéria-prima, objeto do trabalho etc.) como orgânica, inter-relação que pode figurar em pontos determinados da cadeia a que nos referimos, mas antes de tudo assinala a 
transição, no homem que trabalha, do ser meramente biológico ao ser social. (2013. p. 35)

É a partir desta consideração que podemos inferir o trabalho como a categoria fundante do ser social, qualificando-se como um ato radicalmente histórico-social. Não obstante, o desenvolvimento desta "atividade", a despeito de suas complexas teorizações decorrentes, envolve a consideração, como temos tentado demonstrar, do espaço escolar, especialmente quando observamos a emergência da disciplina Geografia e do fenômeno industrial.

Estas breves considerações, dado os nossos objetivos, colocam em evidência a capacidade humana de projetar o seu trabalho e o seu produto, demonstrando o caráter "não-epifenomênico" da consciência, em oposição às sociedades animais (como é o caso das abelhas), cuja limitação biológica é determinante do trabalho. Por conseguinte, o trabalho realiza um pôr teleológico que proporciona um novo produto do trabalho, uma nova materialidade (LUKÁCS, 2013). É pertinente a esta discussão a contribuição de Postone (2014) acerca da constituição histórica que o trabalho assume no capitalismo, ou seja, uma classe de mediação social característica e distintiva desta sociedade. Assim, nos dizeres de Postone

O que, para Marx, torna tão peculiar o tecido dessa estrutura social subjacente é ele ser constituído pelo trabalho, pela qualidade historicamente específica do trabalho no capitalismo. Portanto, as relações sociais específicas e características do capitalismo só existem no meio do trabalho. (p. 246/247)

$\mathrm{O}$ autor atribui grande destaque ao trabalho por considerar que a "formamercadoria" das relações sociais é constituída pelo trabalho. Neste sentido, a centralidade do trabalho é determinada historicamente pelo seu papel no capitalismo, pelo seu aspecto abstrato e dinâmico nas relações sociais. O autor canadense assevera que

O que torna geral o trabalho no capitalismo não é simplesmente o truísmo de ele ser o denominador comum de todos os vários tipos específicos de trabalho; pelo contrário, é a função social do trabalho que o torna geral. Como atividade socialmente mediadora, o trabalho é abstraído da especificidade do seu produto e, portanto, da especificidade de sua própria forma concreta. Na análise de Marx, a categoria de trabalho abstrato exprime esse processo social real de abstração; ele não se baseia simplesmente em um processo conceitual de abstração. Como 
prática que constitui uma mediação social, o trabalho é trabalho em geral. Ademais, estamos tratando com uma sociedade em que a forma-mercadoria é generalizada e, portanto, socialmente determinante; o trabalho de todos os produtores serve como meio pelo qual é possível obter os produtos de outros. Consequentemente, "trabalho em geral" serve de uma forma socialmente geral como atividade mediadora. (2014. p. 244)

$\mathrm{Na}$ sociedade capitalista, por conseguinte, ainda que a mercadoria possa consistir em categoria estruturante de maior destaque, o trabalho constitui a condição para a aquisição dos produtos dos demais trabalhadores, necessários à sobrevivência. Assim, a função do trabalho e dos produtos passa a ser a condição para acessar o produto dos outros. Postone (ibidem) entende esta situação como uma nova forma de "dominação social" e cuja maior evidência é o fato de que a participação de qualquer pessoa nesta sociedade está obrigatoriamente vinculada a ser "trabalhador" e, em consequência, o trabalho é central para a sociabilidade do capital. Marx nos Grundrisse (2011) é bastante claro ao abordar esta nova forma de sociabilidade desenvolvida pela sociedade capitalista, uma vez que nas formas anteriores

\begin{abstract}
Os indivíduos não se relacionam como trabalhadores, mas como proprietários - e membros de uma comunidade que ao mesmo tempo trabalham. A finalidade desse trabalho não é criação de valor - embora eles possam realizar trabalho excedente para trocá-lo por trabalho alheio, i.e., produtos excedentes -; ao contrário, a sua finalidade é a conservação do proprietário singular e de sua família, bem como a da comunidade como um todo. O pôr do indivíduo como um trabalhador, nessa nudez, é ela própria um produto histórico. (p. 628 grifos do autor)
\end{abstract}

Esta discussão guarda profunda vinculação com as problematizações vindouras, especialmente quando percebemos que nesta nova organização social a necessidade de transformação do produto ou da atividade em valor de troca indica que o poder social dos indivíduos consiste numa troca universalmente estranhada, ou seja, sob a égide do capital os sujeitos passam a ser dominados por uma relação social repleta de abstrações. Neste sentido, repensar a ontologia, com a ênfase que dedicamos à abordagem marxista nos espaços escolares, parece fundamental para tornar possível o pensar para além do capital.

Cientes de que o conjunto da obra de Marx não era de natureza epistemológica, mas de cunho ontológico (LUKÁCS, 2012) é fundamental ainda salientar, especialmente após todo o longo percurso já caminhado, que o seu 
principal intuito residia na necessidade de como conhecer um objeto real e determinado, ou seja, no estudo concreto de uma realidade concreta. Lênin (apud NETTO, 2011) é bastante claro ao asseverar que Marx, diferentemente de Hegel, não procurava desenvolver uma ciência da lógica, e, sim, desvendar a lógica de um objeto determinado.

Entendemos que esta constatação pode ser coadunada com a emergência de uma ciência que centraliza e posiciona o homem como objeto do conhecimento, segundo pontifica Foucault (1987). Outrossim, na esteira de toda a discussão empreendida ao longo deste capítulo, acreditamos estar, finalmente, alcançando um terreno teórico-conceitualmente seguro para avançarmos em nossa investigação porquanto a relevância de um resgate da ontologia indica a premência de sobrelevar, no interior do edifício científico, a figura do homem. É através desta premissa que calçamos nosso estudo, ou seja, é justamente por intermédio da inescapável "aliança" entre ontologia e gnosiologia que acreditamos ser possível pensar na superação da pretensa perenidade da sociedade capitalista a partir de uma outra compreensão ontológica do espaço escolar. Todavia, à guisa de conclusão desta discussão, vejamos um pouco melhor como se constituiu esta ciência "humanizada".

\subsection{O homem na ciência e uma aproximação com a escola}

A ruptura entre metafísica e ciência traz em seu seio o aparecimento do homem como um objeto de conhecimento, inaugurando as ciências humanas, mas é preciso constatar que não lhes foi transmitida por herança um domínio já delineado que demandasse a elaboração de conceitos científicos ou métodos positivos. Na realidade, o século XVIII não ofertou "sob o nome de homem ou natureza humana, um espaço circunscrito exteriormente, mas ainda vazio, que elas tivessem, em seguida, a tarefa de cobrir e analisar" (FOUCAULT, 1987. p. 361). As ciências humanas, neste contexto, surgem em meio a uma situação de crise e desprovidas de qualquer esteio que garantisse a organização de seu campo epistemológico porquanto nos séculos XVII e XVIII o homem não existia.

A crise da filosofia e a necessidade de exposição de um contraponto crítico ao discurso e a prática das ciências naturais, até então predominantes, evocam a 
fundação das ciências humanas, cuja emergência histórica é decorrência de um problema, de uma exigência, de um obstáculo de ordem teórica ou prática que se impunha pela sociedade industrial em gestação. No entanto, o fato a ser devidamente explicitado é que, pela primeira vez, desde que existem os seres humanos organizados em sociedade, o homem, individual ou coletivamente, se tornou objeto da ciência, um fenômeno na ordem do saber, cujo acontecimento foi produzido numa redistribuição geral da episteme: "quando, abandonando o espaço da representação, os seres vivos alojaram-se na profundez específica da vida, as riquezas no surto progressivo das formas de produção, as palavras no devir das linguagens" (p. 362). Este é o prelúdio da superação do primado da representação ${ }^{38}$ pelo da positividade (FOUCAULT, 1987), o que significou o abandono de uma representação sustentada do homem à semelhança de Deus e a adoção de uma representação antropocêntrica, colocando o homem, de fato e simultaneamente, como objeto de conhecimento e sujeito de todo tipo de conhecimento. Temos, enfim, a ideia científica de homem.

A ausência de um projeto epistemológico próprio e de instrumentos metodológicos adequados induz as ciências humanas a tomarem o homem como um objeto unitário e representável, turvando a visão integral da realidade humana e retirando a concretude do sujeito, ou melhor, esvaziando-o de um sentido ontológico. É em meio a esse contexto que, concomitantemente, a teoria geral da representação desaparecia e, em contrapartida, a necessidade de interrogar o ser do homem como fundamento de todas as positividades, acarretando um desequilíbrio, ou seja, "o homem tornava-se aquilo a partir do qual todo o conhecimento podia ser constituído em sua evidência imediata e não-problematizada" (p. 362/363). Fundase, assim, em realidade, nas ciências humanas, o "homem objetivo abreviando o

\footnotetext{
${ }^{38}$ A teoria da representação é bastante vasta perpassando ramos das ciências e sua devida explicitação demanda um esforço que, por ora, não realizaremos em virtude do escopo deste capítulo, mas cumpre recuperar a crítica de Lefebvre (1981) ao pensamento hegeliano quando atribui ao filósofo idealista uma sutil teoria de representação que argumenta ser uma etapa, um nível, um momento do conhecimento. Nesse sentido, o conhecimento e os conceitos somente podem progredir através das representações, no entanto estas são consideradas metáforas dos conceitos e cabe à filosofia traduzi-las para a forma do conceito e do pensamento e apresentar à consciência o verdadeiro conteúdo. Outrossim, o conteúdo da filosofia é a verdade efetiva, ou seja, o que se produziu no domínio do espírito (HEGEL, 1992). É correto inferirmos, portanto, que somente o sujeito é a substância verdadeira, ou seja, ele é o ser e sua própria mediação. Em suas próprias palavras esta proposição fica mais clara: "a substância viva é o ser, que na verdade é sujeito, ou - o que significa o mesmo - que é na verdade efetivo, mas só à medida que é o movimento do pôr-se-asi-mesmo, ou a mediação consigo mesmo do tornar-se-outro" (p. 30).
} 
homem real e, junto com ele, o sujeito enquanto qualidade criativa do homem" (LIMA, 1999. p. 46), autorizando o questionamento de todo o conhecimento do homem.

É em meio a esta reordenação geral do cenário científico moderno que entendemos encontrar as formulações ontológicas marxianas, em parceria com Engels, da segunda metade do século XIX, quando apresentam suas análises como estudos sustentados por premissas reais, ou seja, suas análises são constituídas pelos indivíduos reais. Nas palavras de Marx (2011): “Os homens fazem a sua própria história; contudo, não a fazem de livre e espontânea vontade, pois não são eles quem escolhem as circunstâncias sob as quais ela é feita, mas estas lhes foram transmitidas assim como se encontram" (p. 25). Os estudos de Marx e Engels, conforme sugere a obra de Foucault, assinalam uma nova ontologia, cuja pressuposição não se refere àquilo que o homem diz, imagina ou representa, tampouco "os homens pensados, imaginados ou representados para, a partir daí, chegar aos homens de carne e osso; parte-se dos homens realmente ativos [...], do seu processo de vida real" (MARX e ENGELS, 1984. p. 94). Neste contexto o argumento radical é que

Os homens são os produtores de suas representações, de suas idéias e assim por diante, mas os homens reais, ativos, tal como são condicionados por um determinado desenvolvimento de suas forças produtivas e pelo intercâmbio que a ele corresponde [...]. A consciência não pode ser jamais outra coisa do que o ser consciente e o ser dos homens é o seu processo de vida real. [...] Não é a consciência que determina a vida, mas a vida que determina a consciência (Ibidem)

É a partir da análise da realidade histórica e materialista que encontramos, segundo a ontologia marxiana, as determinações das relações entre o ser e a consciência do homem em sociedade (NETTO, 2011), posicionamento que nos é fulcral para investigar, com maior propriedade, desde uma perspectiva ontológica, o espaço escolar. Como já apresentado anteriormente, Marx e Engels (1984) tratam como inquestionável a ideia de que os homens estão diferidos dos animais justamente naquele momento em que começam a produzir seus meios de vida, "passo este que é condicionado por sua organização corporal. Produzindo seus meios de vida, os homens produzem, indiretamente, sua própria vida material" ( $p$. 27). Nessa sociedade, outrossim, a existência objetiva dos indivíduos tem por 
pressuposto a sua existência como trabalhadores, condição que se aprofunda e se complexifica ao longo do tempo, de um processo histórico singular que demonstra como o homem é, ou seja, "tal e como os indivíduos manifestam sua vida, assim são. O que são coincide, por conseguinte, com sua produção, tanto com o que produzem como com o modo como produzem" (ibidem).

Por conseguinte, a existência humana precisa ser produzida pelo próprio homem através do seu trabalho, o que sugere que o homem não nasce homem, mas tem de aprender a sê-lo, aprender a construir sua própria condição de existência. Portanto, a produção homem é, simultaneamente, a formação do homem, ou, em outras palavras, é um processo educativo (SAVIANI, 2007). O trabalho, neste contexto, adquire centralidade apenas nessa sociedade. Somente na sociedade capitalista os sujeitos se relacionam indiferentemente à sua atividade vital especificamente humana, não importando o conteúdo e os fins de suas atividades, que, a final de contas, só lhes serve como forma de acesso às suas condições de vida. Acerca desta condição Marx (2011) entende ser possível verificar que o resultado desse modo muito particular de relação dos produtores com seus produtos é um modo de produção, uma produção das condições materiais de vida, exclusivamente dela, que a faz necessariamente produção crescente.

Outrossim, é sabido que o homem aprendeu a produzir sua existência no mesmo ato de produção, revelando conteúdos através da própria experiência laboral que atestava sua validade, enquanto outros eram abandonados pela sua inexpressividade. $\mathrm{O}$ desenvolvimento do processo produtivo e a consequente apropriação privada da terra conduziram à uma divisão do trabalho, cujas repercussões estão já, em grande medida, apresentadas neste estudo. Isto posto, é possível inferir que a análise marxiana identifica como uma contradição fundamental no cerne do modo de produção capitalista a subsunção dos sujeitos ao produto do seu trabalho, ou melhor, a sujeição à dominação abstrata do produto do seu trabalho como capital (DUAYER, 2012).

É este homem sujeitado que passa a figurar como objeto de estudo. É no interior desta realidade que a acepção do homem passa a requerer pelas ciências positivas seu enquadramento em critérios normativos de acordo com sistematizações homogêneas, isto é, o homem é introduzido no campo científico segundo o padrão de cientificidade estabelecido pelas ciências naturais e submetido 
aos rigorosos padrões de regularidade, aos discursos formalizados e respaldados através de uma observação isenta que permita descrever um modelo de previsibilidade em leis universais. Não há qualquer preocupação com a compreensão dos fenômenos humanos, apenas com a determinação de um conjunto de regras que permita a ordenação das atividades produtivas para o desenvolvimento capitalista (LIMA, 2013). A "positividade" daquele período, portanto, tentou definir as ciências humanas em função das matemáticas, "matematizando" tudo o que for possível e supondo que o restante ainda não recebeu o devido tratamento científico positivo.

Esse contexto sinaliza que as ciências humanas buscavam estruturar seu próprio estatuto científico e encontraram fundamento no método formal experimental, que, em todo caso, concebia o homem fragmentado de acordo com cada especialidade científica (biologia, química, física etc.). Tal procedimento resplandece a desconfiança da ciência em sofrer alguma descaracterização no estudo do subjetivo, mantendo a validade do conhecimento em estreita vinculação com a materialidade ${ }^{39}$, esta entendida como natureza e sociedade - a unidade lógica de todos os fenômenos observáveis, naturais e sociais.

Por conseguinte, é correto observarmos que as ciências humanas se encontravam num entrave de difícil solução. O ingresso no seio das ciências positivas impele a adoção de uma unidade objetiva do homem, dificultando a observação do próprio ente e de sua qualidade de sujeito. Esse obstáculo tenta ser ultrapassado pelo emprego do caráter transcendental da filosofia e colocam em xeque seu próprio estatuto de cientificidade. Em suma, o homem, ou melhor, as ciências humanas se veem diante de uma dupla dificuldade em sua dimensão do saber: "aquela em que se desenrola a analítica da finitude", enquanto objeto do

\footnotetext{
39 Acerca do termo materialidade, Lefebvre (1991) é bastante didático ao discutir a ideia de um "materialismo moderno", que admite a existência da natureza, do mundo, das coisas independentemente de nossa sensação, de nossa consciência, de nosso eu e do homem em geral, colocando em evidência, na base de sua teoria, de que existe em nossa volta objetos e outros seres humanos, e não apenas agrupamentos de sensações. Esse materialismo constata a existência real, efetiva e eficaz da consciência e do pensamento, negando, apenas, que a realidade possa ser definida isoladamente e "destacar-se da história humana (social), do organismo humano e da natureza" e, dessa forma o "materialismo coerente não afirma que os objetos são tais como percebemos, ou que nossas representações imediatas e banais coincidam com o real; o materialismo supõe, ao contrário, que elas correspondem ao real segundo uma lei, que nos cabe investigar" (p. 67/68). Kant é fundamental nessa perspectiva materialista por questionar a correspondência direta entre as sensações e as representações humanas, atribuindo à ciência, entre outras coisas, a função de experimentar e criticar esta correlação.
} 
saber, e "aquela ao longo da qual se repartem as ciências empíricas que tomam por objeto a linguagem, a vida e o trabalho" (idem, p. 368), enquanto sujeito do conhecimento. É de sobremaneira evidente que este duplo movimento - reclamarem um sentido contingente para o homem e, ao mesmo tempo, se consolidarem no interior do conhecimento moderno - coloca em dúvida o estatuto de cientificidade das ciências humanas e manifesta explicitamente sua dispersão, "uma descontinuidade em relação si mesmo, isto é, o fato que o sujeito enquanto qualidade criativa do homem não pode ser apreendido efetivamente de forma objetiva e positiva" (LIMA, 2013. p. 48).

Foucault (1987) desenvolve uma longa argumentação em torno do valor atribuído à economia, biologia e filologia três dimensões em que, segundo seu entendimento, abrem caminho para que as ciências humanas adquiram seu próprio espaço. Neste sentido, as ciências humanas, indubitavelmente, residem no homem e, com efeito, fixa-se em seu viver, em seu falar e em sua produção, ou seja, nas fronteiras imediatas onde o homem se faz. Assim, as ciências humanas não consistem em uma análise do que o homem é por natureza, mas em uma análise do que o homem é em sua positividade (ente que vive, trabalha, fala). A Geografia, em particular, comportou em seu interior debates bastante semelhantes aos desenvolvidos nas esferas mais gerais da ciência, como o desejo de explicar a realidade a partir de leis e a vontade de elaborar um saber de síntese organizado em bases lógicas e qualitativas, relegando a outros campos científicos (como a sociologia e a psicologia) qualquer discussão voltada ao sujeito. Não à toa, Foucault (idem) assegura que o "aparecimento do homem e a constituição das ciências humanas (ainda que sob a forma de um projeto) seriam correlativos de uma espécie de "des-matematização"' (p. 367).

Após todo o percurso traçado nas páginas deste capítulo vejamos uma constatação fundamental para nossa empreitada investigativa. Com Descartes é instaurada uma ontologia sustentada pela dicotomia entre espaço e homem, processo que é alçado à condição de verdade geral com a geometrização do mundo através dos cálculos newtonianos. Nesse interim, como sabemos, à distinção entre corpos físicos e corpos vivos é coadunada a filosofia crítica de Kant, em que a condição de a priori do espaço, inviabiliza qualquer ontologia, inclusive a de viés cartesiano. Assim, o desencontro entre ente e ser trafega ao longo das ciências 
humanas resultando em algumas premissas, tais como nenhum corpo é espacial, mas apenas está no espaço e somente o ente homem é existência. Destas premissas desdobra-se e consolida-se como real uma relação de recíproca externalidade, em que, segundo Moreira (2012),

O espaço é externo ao homem e o homem é externo ao espaço e apenas ocupa nele um lugar, que a física newtoniana vai instituir como relação de continente e conteúdo com seus conceitos de espaço absoluto e espaço relativo e que hoje está na base de toda a visão de geografia (p. 134).

Neste primeiro capítulo, por fim, dedicamos grande atenção às discussões ontológicas e gnosiológicas, com o fito de adentrarmos, de forma mais segura possível, no emaranhado campo discursivo e político de interpretações possíveis da dimensão curricular. Acreditamos ter apresentado que nosso interesse é ontológico e reside nas subjetividades cognoscentes em meio ao modo de produção capitalista e, simultaneamente, encobertas por considerações ônticas distanciadas de seu ser, isto é, os estudos escolares, em Geografia, parecem estar bastante presos aos aspectos fenomênicos dessa realidade e a negligenciar os aspectos ontológicos radicais que o estruturam. Ademais, gnosiologia e ontologia são dois lados de uma mesma proposta de pesquisa que reconhece como indubitável a necessidade de se pensar conjuntamente conhecimento e ser. 
Conhecimentos da Geografia Humana me deram ferramentas para enxergar o mundo de diferentes ângulos. A sociedade e seus desdobramentos não devem ser romantizados, ao entender os problemas que passam pelo mundo globalizado me permitem ser mais empático e entender o porquê estou onde estou.

Resposta de estudante entrevistado

\section{A educação em perspectiva ontológica: trilhando caminhos}

Pensar a escola, com os seus múltiplos processos e agentes envolvidos, é um exercício já bastante antigo e realizado com inegável competência por diversos cientistas de diferentes áreas do conhecimento. Inclusive a própria ciência geográfica já dedicou inúmeros esforços elucidativos da realidade escolar, partindo de diferentes perspectivas teóricas. A escola não é um fenômeno recente, a pedagogia não é uma ciência incipiente e tampouco as disciplinas escolares estão à margem de investigações profundas. Todavia, conforme já mencionado, nos parece haver uma espécie de lacuna nos estudos geográficos em torno dos sujeitos cognoscentes, sinalizando que nossa preocupação reside, de fato, numa interrelação entre o currículo escolar, com destaque para o de Geografia, e a temática ontológica.

Com base nas fundamentações teórico-conceituais estabelecidas até aqui entendemos ser chegado o momento de aprofundar a discussão em torno do currículo escolar a partir das premissas investigativas que nos orientam. Nossa argumentação não versa especificamente sobre questões espaciais ou escolares, em termos estritos, mas está calcada na abordagem curricular a partir da já apresentada questão ontológica de viés marxiano/marxista, que nos fornece o cabedal científico adequado para interpretar o que podemos denominar de "projeto escolar burguês". É por esta via investigativa que procuraremos, ao longo das próximas páginas, iluminar o referido projeto escolar de Estado em sua dimensão ontológica, cuja manifestação está estampada nas relações de produção capitalistas e, segundo nossa compreensão, também está manifestada nos currículos escolares. Desenvolveremos, por fim, uma discussão acerca da educação sob a perspectiva crítico-marxista de Gramsci com o fito de fundamentar o estudo sobre o currículo escolar, quando, no próximo capítulo, tomaremos como referência concreta os 
documentos oficiais de ensino que organizaram o ensino médio do país até meados da década de 1990.

É importante mencionar que nossa opção por documentos oficiais se deve a algumas razões. Acreditamos que somente partindo das propostas oficiais poderemos tecer uma análise crítica coerente e balizada porquanto é necessário conhecer o conteúdo, as implicações socioeconômicas e políticas relacionadas. Também é indiscutível a capacidade reguladora presente no currículo oficial, ainda que, muitas vezes, sua interpretação e execução sejam flexíveis, mas de qualquer forma é um dos determinantes da prática educativa. Nesse contexto, e ainda à guisa preambular, o currículo oficial cumpre papel orientador de outros aspectos presentes no dia a dia da prática escolar, orientando a organização das grades curriculares e dos planos de ensino de cada disciplina, bem como é base dos livros didáticos. Dessa maneira, estamos de acordo com Sacristán (2020) que aborda o currículo oficial como mediado pelo contexto social, político, econômico e cultural, ou seja, a sua análise demanda a consideração conjunta destas dimensões, uma vez que o currículo proposto é resultado de escolhas assumidas no interior deste amplo contexto.

Por conseguinte, entendemos ser indispensável a compreensão do currículo oficial como investigação das intenções presentes nas políticas oficiais, permitindo que seu estudo nos leve a percebê-lo como processo, uma verdadeira práxis, isto é, perceber que sua construção está prenhe de ideias e práticas que se materializam no contexto do mundo real. Esta premissa ganha ainda mais relevância quando tratamos do currículo escolar da Geografia, disciplina que se transformou ao longo das décadas, acompanhando, em alguma medida, as mudanças no campo científico acadêmico, mas que sempre reservou seu quinhão explicativo nas manifestações propriamente materiais do mundo. Esta prerrogativa, como veremos posteriormente, resguarda grande importância na formação escolar dos sujeitos.

Este preâmbulo buscou apresentar uma breve síntese das principais discussões a serem empreendidas nas páginas seguintes. É nosso intuito, de início, discutir a intrínseca relação estabelecida entre o projeto escolar de Estado burguês e a questão ontológica sob a perspectiva desenvolvida por Marx. Esta discussão nos obriga o retorno ao século XIX e princípio do século XX, quando, por um lado, triunfa o capitalismo industrial e suas revoluções técnicas, e, por outro lado, 
emerge, na esteira da Revolução Francesa, um projeto escolar próprio, com objetivos, métodos, ainda servindo, é bem verdade, como fundamento da escola contemporânea. Estes dois movimentos concorrentes impõem uma espécie de refundação da escola em sintonia com os novos desígnios da sociedade liberal capitalista em curso e manifestada nos currículos oficiais que serão objetos de estudo na etapa final do capítulo. Em nosso caso particular, considerando todo o contexto que envolve esta pesquisa, adotamos especialmente as contribuições de Marx (1996; 2008; 2011), Lukács (2012; 2013) e Gramsci (2015; 2016) como nossos faróis de orientação teórica para o devido debate em torno da ressignificação da formação escolar dos sujeitos, transformados em mercadoria, com a ascensão da burguesia e com as mudanças científicas empreendidas a partir das proposições inovadoras trazidas por Marx no campo ontológico. A temática curricular, por sua vez, será abordada a partir das contribuições teórico-conceituais ofertadas por Sacristán (2001; 2020), Apple (2006) e Silva (2005), pensadores que procuram demonstrar a íntima relação existente entre a temática curricular e a organização da sociedade capitalista, utilizando conceitos do pensamento marxista.

\subsection{A ontologia e o currículo escolar: uma discussão necessária}

As premissas ontológicas apresentadas e toda a discussão empreendida nos parecem sólidas suficientes para progredirmos na discussão em torno do projeto escolar burguês, ou melhor, no processo de formação escolar dos sujeitos modernos, cujo projeto e ideário partia dos interesses burgueses e adquiria manifestação evidente nos currículos escolares.

A despeito das (bem) possíveis imprecisões temporais e conceituais da proposta adotada, o que nos interessa é refletir sobre como as transformações socioeconômicas e políticas provocadas pelo desenvolvimento do sistema capitalista influenciaram a organização das instituições escolares e, mais especificamente, demandaram a produção de habilidades individuais que coube ao projeto escolar de estado burguês atender e que podemos captar a partir dos documentos curriculares oficiais. Deste modo, é indubitável que a íntima relação existente entre o desenvolvimento da sociedade moderna burguesa e o modo de 
produção capitalista encontrou no currículo escolar um ponto de ancoragem seguro para se reproduzir e produzir sujeitos à sua feição e interesse.

Nesse sentido, pensando num quadro contextual ampliado, segundo Hobsbawm (2015), as grandes revoluções burguesas ocorridas a partir de 1789, na França, e, em momento semelhante, no setor produtivo industrial inglês encetam um novo conjunto de palavras que redefinem a compreensão do já discutido "mundo moderno". O historiador inglês enaltece a prevalência não da igualdade e da liberdade em geral, mas da classe média e da sociedade burguesa liberal, bem como não da indústria, mas da indústria capitalista. É por essa via analítica que "indústria", "industrial", "fábrica", "classe média" ', "classe trabalhadora", "capitalismo", "aristocracia" e "ferrovia", "liberal" e "conservador" entram em cena de forma radical e redimensionam o espectro analítico.

Esse novo ideário de cunho burguês, como sabemos, questionava a antiga sociedade, formada por senhores e servos, nobres privilegiados e clero intocável, propondo sua substituição por uma organização social mais justa e igualitária, segundo seus princípios e parâmetros. Assentada nesta ideia de "igualdade", a burguesia, classe emergente de então, buscou estruturar os sistemas de ensino e pregar uma escolarização para todos, já que através dela os servos poderiam se tornar cidadãos e participar do processo político, consolidando a nova ordem. A burguesia não detinha terras, mas o capital, que já fora emprestado ao Estado e o desejava de volta. Conhecedora da administração pública temia que o governo fracassasse e perdesse suas economias, situação que estimulou a ideia de que seu poder político correspondesse ao seu poder econômico, ou seja, a classe já detentora de propriedades também almejava toda sorte de privilégios, garantindo que suas posses estivessem desimpedidas de quaisquer restrições relacionadas à decadente sociedade feudal. Estruturou, assim, seu espaço não apenas no governo, mas tornouse o próprio governo. O caso francês é bastante emblemático porque o país encontrava-se numa crise sem precedentes que impediam a manutenção de seu regime político.

Naquele país, em profunda efervescência política, assim como em grande parte do mundo havia o predomínio de uma população rural, pouco letrada e precariamente informada sobre o que quer que ultrapassasse os limites de seu departamento. Os poucos jornais, restritos a uma pequena parcela das classes média 
e alta, limitavam as informações a um seleto grupo e tornavam a leitura um privilégio. As considerações de Hobsbawm (2015) sugerem, tendo por base a realidade europeia ocidental, um mundo repleto de sujeitos estritamente vinculados a sua realidade mais imediata, ou seja, detentores de um conhecimento local e palpável às próprias mãos, cujo corpo pode ser encarado como o principal vínculo de contato com o mundo através dos sentidos. Corpo e espaço consistem em imbricada relação, cujo conhecimento vai se revelar fundamental para a organização da sociedade burguesa em tempos de expansão da máquina à vapor e do sistema fabril em larga escala. É no interior deste processo que o conhecimento do espaço revela como o controle do corpo pode se tornar valioso recurso para otimização do trabalho e garantia da manutenção da ordem burguesa. Não é difícil perceber que essa alteração no modelo produtivo impõe o desenvolvimento de um outro conjunto de trabalhadores, aptos ao ritmo industrial, ao rigor dos chefes e ao manuseio de outros instrumentos e utensílios.

Se o olharmos o período contemporâneo veremos que houve diversas mudanças na organização produtiva, a chamada compressão espaço-tempo adquiriu ainda maior densidade, as relações humanas se desdobram, em grande medida, sobre o tecido virtual das comunicações e, consequentemente, diversos trabalhadores também assistem às transformações tecnológicas, às alterações jurídicas, assim como às mudanças em sua formação profíssional. O ritmo acelerado da vida e do trabalho contemporâneos simboliza um grande contraste com os séculos passados, cabendo reafirmar que sua organização data do final do século XVIII e início do XIX. Destarte são produtos e construtos sociais, cujas histórias ainda precisam ser mais e melhor apresentadas, como também suas condições precisam ser constantemente reproduzidas. O grupo humano de trabalhadores percorreu uma longa jornada até aqui e este caminho consiste em um processo prenhe de conflitos, cujo conhecimento já é demasiado sabido, mas em nosso entender, carece de uma maior explicitação da vinculação com o aparato político escolar, especialmente em termos ontológicos.

Não é sem motivo que a sociedade contemporânea alimenta a ideia de que existe um "mundo de oportunidades" a nossa espera, despertando em grande parte da população a sensação do fracasso, a perda de confiança e a auto-culpabilização. No "mundo das oportunidades" o falacioso discurso da igualdade de chances 
transforma todos os sujeitos em vencedores ou perdedores, situação modificada em relação aos séculos passados quando a posição de cada um já estava definida pelo seu "berço". Os ricos e pobres, os vitoriosos e os fracassados de hoje, devem não apenas suportar sua condição, mas devem ser considerados e se considerar responsáveis por ela (ENGUITA, 1999). Esta mudança veio à tona com a emergência da chamada sociedade industrial, quando o mercado tornou instável o lugar de cada um e acarretou uma percepção de que cada pessoa é diretamente responsável pelo nosso lugar no mundo, ou seja, “consideravam seus êxitos ou seus fracassos na luta pela existência como questão de força ou debilidade pessoal (SENNET, 1980).

Estas transformações nos parecem guardar uma mesma raiz: o trabalho. De acordo com nossa perspectiva analítica cabe reafirmar que suas mutações, desde o período de subsistência até a sociedade industrial, ou, se preferirmos, até a pósindustrial, alterando sua função social, suas finalidades econômicas e sua organização laborativa provocam indiscutíveis mudanças na organização do conjunto da sociedade. Concentrando nosso olhar no período em questão é bastante nítida a transformação da atividade trabalho pela ampla adoção de máquinas na indústria e os decorrentes rearranjos sociais, como bem mostrou Chaplin em seu Tempos Modernos.

É fundamental coadunarmos a esse cenário de profundas transformações as ocorridas no interior da ciência, como as apresentadas no capítulo anterior. Estruturada sobre terreno objetivo, a ciência positiva posiciona o objeto científico como verdade inquestionável, desconsiderando qualquer ponderação pessoal, e coloca o homem como simples objeto no interior de mais um grupo biológico a ser decodificado por um conhecimento específico. Por um lado, portanto, o edifício ontológico objetivista estava construído e a ciência moderna relegou ao sujeito o quinhão da passividade, mero observador da natureza ou um próprio objeto do conhecimento objetivo; e, por outro lado, a razão e seus métodos fincavam raízes fortes para simbolizar e difundir no meio social os valores da ordem, do equilíbrio e do progresso humanos. É evidente que o aparato escolar refletia, à sua maneira, estas transformações e, por conseguinte, os sujeitos e subjetividades cognoscentes envolvidos foram "reconstruídos" para atender o que era demandado pela sociedade 
a partir daquilo que a ciência definia como conhecimento a ser amplamente reproduzido.

É a partir deste amplo cenário que procuramos situar nossa discussão ontológica em meio à realidade escolar em formação. A partir deste momento, ganha destaque algumas propostas investigativas críticas da dimensão escolar na sociedade burguesa.

\subsection{A educação e seu papel político na sociedade capitalista}

A Revolução Francesa, liderada pela burguesia, desejava instaurar um novo modelo de instrução e se apropria da ideia de educação pública adotada pela Reforma protestante, redefinindo-a em um instrumento capaz de difundir sua visão de mundo. Por conseguinte, se a Reforma de Lutero buscava contribuir com Deus para sua obra de construção do mundo, para a classe burguesa o objetivo é a realização do individual para a construção do progresso geral. Território em profunda transformação social e política, a França organiza, em 1782, um plano de instrução pública, pautado pela publicidade, universalidade, gratuidade, laicismo e obrigatoriedade. É interessante assinalar que o próprio Marx, pensando a realidade alemã já no final do século XIX, realizou duras críticas ao programa de educação do partido operário alemão, enfatizando a ambiguidade da gratuidade do ensino ao escrever que

\footnotetext{
"Escolarização universal obrigatória. Instrução gratuita." A primeira existe na Alemanha, a segunda na Suíça [e] nos Estados Unidos, para escolas públicas. Que em alguns estados deste último também sejam "gratuitas" as instituições de ensino "superior" significa apenas, na verdade, que nesses lugares os custos da educação das classes altas são cobertos pelo fundo geral dos impostos. (MARX, 2012. p. 45/46)
}

É em meio a esse período de transição político-social francês que a burguesia investe seus esforços na tentativa, inclusive através da educação, de transformar súditos em cidadãos, buscando romper com o modo de produção feudal e recrudescer o modo de produção capitalista. O projeto escolar em desenvolvimento surge como uma ferramenta capaz de proliferar os conhecimentos adquiridos pela humanidade, suprimindo um até então permanente estado de ignorância, e, simultaneamente, introduz a sociedade na concepção burguesa 
emergente de mundo. A referida classe social, precipuamente interessada na defesa da igualdade e da liberdade, uma vez consolidada no poder, reposiciona seus interesses na perpetuação das estruturas sociais, priorizando a expansão do sistema de ensino, que é utilizado para assegurar a hegemonia burguesa e a reprodução das relações de classe capitalistas (PEREIRA, 1999). A partir daquele momento a instrução passa a ser divulgada como meio de redenção social, tomando para si a tarefa de equalizar racionalmente os indivíduos e de ceifar problemas sociais que os valores igualitários apregoados pela Revolução Francesa não conseguiriam eliminar.

Diversos foram os estudiosos que nos antecederam e já se debruçaram sobre este projeto escolar e seus interstícios político-econômicos. Nesse contexto, é predominante a retórica em torno do Estado que conserva, simultaneamente, uma atribuição instrucional e que procura, por meio da educação, instaurar uma função "igualizadora", assim como também institui, legitima e protege a propriedade privada. Disso conclui-se que a tarefa redentora concedida à educação já nasce condenada ao fracasso em sua origem. Expoentes importantes desse viés analítico acerca do projeto escolar burguês a partir da crítica da sociedade capitalista, marcada pela estrutura de classes, decorrente da divisão social do trabalho, baseada na apropriação diferencial dos meios de produção, podem ser considerados os trabalhos de Bourdieu e Passeron (1982), de matiz weberiano, e Althusser (1983), mais vinculado ao pensamento marxista. Estes trabalhos, cada um à sua maneira, entendem o projeto escolar burguês como uma instituição que preenche duas funções estratégicas para a sociedade capitalista: a reprodução da cultura e a reprodução da estrutura de classes. Sabe-se que ambas as funções se encontram intimamente relacionadas uma vez que é função geral da escola burguesa garantir a reprodução das relações sociais de produção.

Ainda que não seja nossa temática principal é relevante escrevermos algumas linhas acerca destas duas proposições com o fito de robustecer uma "terceira via" analítica da relação entre Estado e educação. Esta "terceira via", se é que a podemos chamá-la assim, é trazida à baila através do pensamento do filósofo marxista italiano Antonio Gramsci (1891-1937). A contribuição e extensão do pensamento gramsciano é reconhecidamente vasto e, por isso, nos limitamos a retomar alguns itens de sua biografia para contextualizá-lo e delinear sua inserção 
em nossa pesquisa, cujo foco é a sua análise do Estado concernente ao campo educacional.

Cabe ressaltar que os pensamentos a serem visitados não estão cronologicamente expostos, condição que implicaria num empobrecimento do debate, uma vez que o pensamento gramsciano permaneceu recôndito, no debate brasileiro, durante longo período e somente adquiriu destaque a partir de meados da década de 1970, juntamente com os outros autores de viés marxista. Assim, optamos por destacar inicialmente as contribuições de Althusser e Bourdieu \& Passeron para, aí sim, a partir daquilo que estes pensadores nos apresentam, trazer à tona as proposições de Gramsci. Façamos esse caminho pelo início.

As proposições científicas de Althusser e Bourdieu \& Passeron estão inseridas no movimento de amplo desenvolvimento de teorias sociais críticas do pós-Segunda Guerra Mundial na Europa e na América do Norte, cujos efeitos chegam ao Brasil em meados da década de 1960 a partir de intelectuais progressistas e educadores dedicados a refletir temas como justiça social e em oposição à ditadura civil-militar recorreram ao pensamento marxista para a discussão das questões educacionais. A menção a este contexto sociopolítico torna inescapável a referência ao trabalho de Paulo Freire, ícone da intelectualidade brasileira e figura de grande comprometimento político com as camadas populares, considerado o primeiro grande pensador brasileiro vinculado às teorias educacionais críticas. Seu pensamento ainda terá o devido espaço neste estudo.

Isto posto, o pensamento de Althusser alcançou grande repercussão no Brasil por volta da década de 1970 através da noção de "aparelhos ideológicos de Estado", dentre os quais se destacava a escola. O pensador alemão desejava avançar na teoria marxista de Estado, segundo a qual a reprodução das relações de produção é uma exigência, ou seja, é fundamental garantir a reprodução da força de trabalho e, ao mesmo tempo, a sujeição dos trabalhadores à ordem dominante.

Louis Althusser pode ser considerado o principal representante da corrente marxista estruturalista, corrente antagônica à proposta gramsciana, e que retoma a metáfora marxiana de estrutura e superestrutura ${ }^{40}$ afirmando ser este o edifício que

\footnotetext{
${ }^{40}$ Os conceitos de estrutura e superestrutura derivam do interesse marxiano de compreensão da organização e estrutura da sociedade capitalista em estudos iniciados acerca da filosofia do direito de Hegel. Neste sentido, em síntese, o próprio Marx escreve que "na produção social da própria
} 
explica a sociedade, situando a economia na base como determinante de toda a superestrutura - instituições jurídicas, políticas e ideológicas (ALTHUSSER, 1983). É a partir desta leitura do pensamento de Marx que Althusser acredita estar diante de uma das maiores descobertas científicas da história, entendendo que Marx inaugura "uma nova problemática, um novo modo sistemático de apresentar as questões ao mundo, novos princípios e um novo método. Essa descoberta está contida imediatamente na teoria do materialismo histórico" (1967. p. 202).

Este "novo método" traz em seu cerne a premissa de que o objeto científico da história é a "totalidade (social) complexa", conceito que reporta à ideia de "estrutura", ou melhor, a um complexo de estruturas intercambiantes no interior do edifício social. A leitura que Althusser faz dos escritos de Marx implica uma necessária priorização da "estrutura específica da totalidade" que vai permitir a compreensão "da coexistência de seus membros como as relações constitutivas e a estrutura da própria história (ALTHUSSER, BALIBAR \& ESTABLET, 1980. p. 37/38). Apoiados em diferentes fragmentos da obra marxiana, os autores asseveram que a

Estrutura do todo é articulada como a estrutura de um todo orgânico hierarquizado. A coexistência dos membros e relações no todo está sujeita à ordem de uma estrutura dominante, que introduz certa ordem específica na articulação dos membros e das relações. (Ibidem)

Em nosso entendimento, é possível afirmar que esta linha argumentativa fundamenta toda a discussão acerca do chamado "Estado repressor", justamente o agente responsável pela ordem dominante imposta na estrutura social. Distantes de promovermos um mergulho profundo ao redor das considerações de Althusser, o

existência, os homens entram em relações determinadas, necessárias, independentes de sua vontade; essas relações de produção correspondem a um grau determinado de desenvolvimento de suas forças produtivas materiais. A totalidade dessas relações de produção constitui a estrutura econômica da sociedade, a base real sobre a qual se eleva uma superestrutura jurídica e política e à qual correspondem formas sociais determinadas de consciência. O modo de produção da vida material condiciona o processo de vida social, política e intelectual. Não é a consciência dos homens que determina o seu ser; ao contrário, é o seu ser social que determina sua consciência" (2008. p. 47 grifos nossos). Destarte é possível perceber que a estrutura consiste na base econômica da sociedade onde residem as relações de trabalho marcadas, por conseguinte, pela exploração das forças de trabalho, enquanto que a superestrutura corresponde às estratégias implementadas pelos grupos dominantes para perenizar seu poder de dominação. Não obstante, como veremos melhor mais à frente, Gramsci também se notabilizou por ser um exímio decodificador dos fenômenos superestruturais (políticos, culturais etc.), contribuindo de sobremaneira para a crítica ontológica, uma vez que não se restringiu à esfera econômica, mas avançou em outras dimensões do ser social. 
que nos evita uma jornada investigativa ainda mais extensa, cumpre salientar que o autor aprofunda sua análise ao abordar a teoria de Marx e Engels, acerca do Estado repressor, para distinguir o poder de Estado do aparelho de Estado. A luta de classes, neste contexto, diz respeito ao poder de Estado, que deve ser tomado pelo proletariado para destruir o Estado burguês. A tomada do poder de Estado permitiria ao proletariado substituir o aparelho de Estado repressivo por outro, de orientação proletária. Assim, o autor identifica, além dos aparelhos repressivos (governo, judiciário, as prisões, a polícia, o exército), cuja função é garantir através da força as condições políticas para a reprodução das relações de produção, os aparelhos ideológicos (religião, educação, família, imprensa, cultura), que garantem, predominantemente pela ideologia, a reprodução das relações de produção.

A apresentação destes aparelhos ideológicos impele ao autor a explicitação de seu entendimento sobre ideologia. Althusser afirma que ela não tem história e "representa a relação imaginária dos indivíduos com suas condições reais de existência" (1983. p. 77) ou, dito de outra forma, "na ideologia, o que é representado não é o sistema das relações reais que governam a existência dos indivíduos, mas a relação imaginária destes indivíduos com as relações reais em que vivem” (p. 82). Os aparelhos ideológicos de Estado, por sua vez, através de suas práticas e rituais próprios, desenvolvem as ideologias e colaboram com a reprodução das relações de produção ao garantirem a opressão e exploração de classe.

A relação entre educação e ideologia, nas sociedades capitalistas modernas, é materializada na instituição escolar ao exercerem a função de reprodução das relações de produção. $\mathrm{O}$ autor atribui ao processo de aprendizagem a inculcação da ideologia de classe dominante com o claro objetivo de reprodução das relações de exploração típicas da sociedade capitalista, mas escamoteadas pela ideia de a escola ser um território "neutro". Por conseguinte, é a ideologia que induz os sujeitos a compreenderem a escola como algo universal e, simultaneamente, esconder seu papel difusor dos interesses das classes dominantes.

A contribuição de Althusser provocou profundos debates e foi acompanhada pelas proposições de Bourdieu e Passeron (1982) que, analisando a educação francesa, identificaram uma estreita vinculação entre a reprodução cultural e reprodução social. Por caminhos distintos, ambos trabalhos reafirmam uma abordagem estruturalista da sociedade, sustentando a ideia de que o papel da escola 
é a reprodução da estrutura social através da difusão, para os franceses, de habitus, como veremos melhor logo em seguida, e, para o alemão, da ideologia em prol da manutenção da sociedade de classes. Todavia, este viés analítico foi crivado de críticas pela supressão da categoria contradição, sugerindo que o mecanismo da reprodução se desdobrava sem antagonismos de classes (DORE, 2006).

A observação mais atenta ao trabalho dos franceses sugere que a instituição escolar, em posição semelhante à Althusser, cumpre papel sociopolítico fulcral na organização da estrutura social ao promover a produção de "ilusões" com efeitos bastante concretos na sociedade. No interior desta premissa reside a compreensão de que a escola funciona como mecanismo reprodutor das desigualdades sociais e de promoção implícita dos valores e símbolos da cultura dominante. O funcionamento adequado deste mecanismo requer o chamado habitus, constituído pela incorporação de práticas sociais e de experiências do passado, consistindo no princípio gerador de práticas que representam um indivíduo ou uma classe de indivíduos dentro de uma estrutura social. Assim, o habitus existe a partir da família, da vida cotidiana e das instituições sociais que estruturam a sociedade e permitem o desenvolvimento de um processo de socialização entre instâncias e indivíduos que irão reproduzir indefinidamente formas de ser e de agir até sua completa naturalização nas práticas sociais. É justamente essa "aceitação natural" de ideias e atos que fundamentam o habitus e, por conseguinte, adquire status de verdade a representação pelos indivíduos das classes sociais.

Tema de diversas críticas, o habitus, segundo os pensadores franceses, ao longo do processo de socialização favoreceriam os estudantes oriundos da burguesia por já possuírem capacidades prévias advindas de sua origem familiar. Por outro lado, os filhos das classes trabalhadoras sofreriam o problema inverso, ou seja, a distância de seus progenitores da cultura escolar corresponderia a um entendimento de que não pertencem àquela cultura, deslegitimando para sua própria vida os conteúdos escolares. Mesmo aquele que insistem em prosseguir na jornada escolar, segundo os franceses, optariam por carreiras menos valorizadas, sugerindo que suas capacidades intelectuais não são capazes de alcançar profissões de maior reconhecimento social.

De modo divergente a estas abordagens está o pensamento de Gramsci, todavia antes de avançarmos em suas formulações, e considerando o contexto 
sociopolítico de sua época, é relevante recorrermos aos escritos do próprio Marx, onde encontramos algumas das possíveis inspirações do pensador italiano e que também nos são de grande valia. Marx (2008), no prefácio, escreve sobre seus estudos e áreas de pesquisa, e é bastante claro ao afirmar que

Na produção social da própria existência, os homens entram em relações determinadas, necessárias, independentes de sua vontade; essas relações de produção correspondem a um grau determinado de desenvolvimento de suas forças produtivas materiais. A totalidade dessas relações de produção constitui a estrutura econômica da sociedade, a base real sobre a qual se eleva uma superestrutura jurídica e política e à qual correspondem formas sociais determinadas de consciência. $\mathrm{O}$ modo de produção da vida material condiciona o processo de vida social, política e intelectual. Não é a consciência dos homens que determina o seu ser; ao contrário, é o seu ser social que determina sua consciência (p. 47 grifos nossos).

Pouco mais à frente identificamos outra valiosa contribuição:

Do mesmo modo que não se julga o indivíduo pela ideia que de si mesmo faz, tampouco se pode julgar uma tal época de transformações pela consciência que ela tem de si mesma. É preciso, ao contrário, explicar essa consciência pelas contradições da vida material, pelo conflito que existe entre as forças produtivas sociais e as relações de produção (p. 48 grifos nossos).

As duas passagens acima são extremamente profícuas em ideias que poderíamos desenvolver nesse estudo, no entanto, dentre a miríade de temas possíveis, entendemos que os dois trechos grifados estão intimamente interconectados com nosso objetivo central, ou seja, o pensamento de Marx coadunado às proposições de Gramsci se revelam preciosos ao discutir os princípios gnosiológicos e ontológicos presentes na estreita vinculação entre Estado e sociedade civil, assim como por realizar uma leitura dialética da tensão entre estrutura e superestrutura, retomando a ideia de que os homens tomam consciência dos conflitos sociais no nível das superestruturas. É o plano das superestruturas, onde localizamos as instituições escolares, com seus respectivos programas curriculares, que nos interessa, ou seja, toda a discussão que desenvolveremos a seguir tem por fundamento compreender o posicionamento gramsciano acerca da escola. É evidente que não temos a pretensão de construir uma recuperação bibliográfica da vasta produção de Gramsci, cabendo ressaltar que as linhas 
seguintes foram pensadas e escritas com o fito de promover uma sólida argumentação para a compreensão do que seria um projeto escolar de Estado (burguês) a partir de uma perspectiva crítica marxista. O alcance desse intento é fundamental para que consigamos circunscrever com segurança o currículo escolar em suas ações práticas e teóricas envolvendo os sujeitos cognoscentes.

Portanto, inicialmente, afirmamos que a adoção do posicionamento de Marx acerca da noção de Estado, implica, diretamente, em sua antítese, a sociedade civil, conceito central para a teoria política de Gramsci por consistir na esfera de mediação entre a infraestrutura econômica e o Estado em sentido estrito. Bobbio (1982) faz uma longa reflexão sobre a noção de sociedade civil e atribui à Marx o seu significado como algo que se estende a toda "vida social pré-estatal, como momento do desenvolvimento das relações econômicas, que precede e determina o momento político e, portanto, como um dos dois termos da antítese sociedadeEstado" (p. 30).

Em A ideologia alemã Marx e Engels apresentam uma célebre formulação sobre sociedade civil bastante oportuna para este momento da pesquisa, quando afirmam que

\begin{abstract}
A forma de intercâmbio, condicionada pelas forças de produção existentes em todas as fases históricas anteriores e que, por sua vez, as condiciona, é a sociedade civil. [...] Vê-se, já aqui, que esta sociedade civil é a verdadeira fonte, o verdadeiro cenário de toda a história, e quão absurda é a concepção histórica anterior que, negligenciando as relações reais, limitava-se às ações altissonantes dos príncipes e dos Estados. A sociedade civil abrange todo o intercâmbio material dos individuos, no interior de uma fase determinada de desenvolvimento das forças produtiva. Abrange toda a vida comercial e industrial de uma dada fase e, neste sentido, ultrapassa o Estado e a nação [...]. A expressão "sociedade civil" aparece no século XVIII, quando as relações de propriedade já se tinham desprendido da comunidade antiga e medieval. A sociedade civil, como tal, desenvolve-se apenas com a burguesia; entretanto, a organização social que se desenvolve imediatamente a partir da produção e do intercâmbio e que forma em todas as épocas a base do Estado e do resto da superestrutura idealista, foi sempre designada, invariavelmente, pelo mesmo nome (1984. p. 52/53 grifos nossos).
\end{abstract}

A escolha deste entendimento de sociedade civil torna imperiosa a explicitação das duas linhas argumentativas paralelas e não excludentes que orientam a crítica de Marx ao Estado moderno (POGREBINSCHI, 2009). De um 
lado, está o posicionamento, desenvolvido na supramencionada obra, relacionando a formação do Estado moderno à evolução histórica da propriedade privada, ou seja, a emergência deste ente político corresponde a um novo modo de produção e a uma determinada divisão do trabalho que encontra na propriedade privada sua principal feição a ser protegida e garantida, perspectiva que remonta a análise marxiana da economia política. Nesse sentido, segundo interpretação de Bobbio, é justamente nesta oposição que se apresenta a antítese fundamental do sistema, ou seja, entre estrutura e superestrutura. Por outro lado, a segunda via argumentativa registra a argumentação de que o Estado moderno é erigido na Revolução Francesa, evento histórico já mencionado, que marca a cisão da vida em duas esferas distintas, a política e a não política.

Ao concentrarmos nosso olhar nas formulações gramscianas recorremos, primeiramente, às interpretações de Bobbio (1982) e Coutinho (1992). Estes autores afiançam que o conceito de "sociedade civil" é basilar para a compreensão do pensamento de Gramsci, todavia é preciso sublinhar que enquanto Marx identifica a sociedade civil com base material, com infraestrutura econômica, Gramsci entende que a sociedade civil não pertence ao momento da estrutura, mas ao da superestrutura (BOBBIO, 1982). Essa diferença adquire caráter radical em nosso estudo por consistir numa ampliação do alcance do conceito de sociedade civil, implicando, simultaneamente, no alargamento do conceito de Estado, o que significa, por conseguinte, um outro posicionamento teórico e prático das instituições escolares nas formulações gramscianas. Vejamos melhor esta questão.

Gramsci $^{41}$ atribui ao conceito de sociedade civil a possibilidade de enriquecer a teoria marxista de Estado, com novas determinações, e, ademais, permite inferir que o pensador italiano mantém sua convicção no materialismo

\footnotetext{
${ }^{41}$ É importante afirmar que o pensamento gramsciano está totalmente inserido no contexto político pré-Primeira Guerra Mundial e no movimento operário italiano. É a partir deste contexto que o filósofo demonstra preocupação com as condições de miséria e de pauperização imposta à população sarda, bem como a possibilidade de constituição de canais de debate socialistas que viabilizassem ao sardo um processo de formação intelectual. Também é interessante frisar que Gramsci questiona as condições materiais impostas pelo capitalismo que desembocaram nas profundas diferenças entre o Sul e Norte italianos (FRESU, 2016). Cumpre destacar, especialmente atentos aos nossos objetivos, que em um período de grande destaque ao positivismo e determinismo, Gramsci voltou o seu olhar aos "desvios" realizados no pensamento de Marx, quando explicitou sua frustração com o Partido Socialista da Itália e com os sindicatos (Ibidem) e desenvolveu teoria que nos permite pensar a relação entre Estado e educação, ou melhor, possibilita dedicar especial realce à crítica da ideia de que a educação e a cultura, compondo a propalada "superestrutura", seriam mecanicamente determinadas pela economia.
} 
histórico, ou seja, na ideia de que a produção e reprodução da vida material, envolvendo a produção e reprodução das relações sociais, é o fator ontológico central na explicação da história (COUTINHO, 1992). Ao pensarmos como ocorre esse enriquecimento não podemos obnubilar o contexto político-social vivenciado por Gramsci, período de complexificação do Estado e de intensificação da organização dos grupos proletários, sobretudo no final do século XIX na Europa ocidental, com sindicatos, partidos e defesa e conquista do sufrágio. É em meio a tantas transformações que Gramsci apresenta seu conceito de "sociedade civil" e sua concepção ampliada de Estado, reconhecendo a socialização da política no capitalismo moderno europeu e a formação de organizações coletivas de massa.

Gramsci (1982) é cristalino ao conceber a "sociedade civil" como um dos grandes "planos superestruturais" (em consórcio com a "sociedade política ou Estado"), onde os intelectuais estariam inseridos juntamente com um conjunto de organismos comumente chamados de "privados". Na perspectiva gramsciana estes dois grandes "planos superestruturais" correspondem "à função de 'hegemonia' que o grupo dominante exerce em toda a sociedade e àquela de domínio direto ou de comando, que se expressa no Estado e no governo 'jurídico'. Estas funções são precisamente organizativas e conectivas" (p. 11 grifos nossos).

Dessa passagem depreende-se que, segundo o olhar de Gramsci, o Estado, em sentido amplo, comportaria duas esferas principais, a "sociedade política" (ou "Estado em sentido estrito" ou "Estado-coerção"), formada pelo conjunto de mecanismos e de instrumentos através dos quais as classes dominantes exercem o monopólio legal da repressão e da violência, e que se identifica com os aparelhos de coerção sob controle das administrações executiva e policial-militar; e a "sociedade civil" constituída justamente pelo conjunto de organizações pela elaboração e/ou difusão das ideologias, aí incluindo igrejas, o sistema escolar, os partidos políticos, os sindicatos, as organizações profissionais, a organização material da cultura, como os jornais, revistas, editoras etc. (COUTINHO, 1992). Estas duas esferas, por conseguinte, concorrem para a promoção ou conservação de uma mesma base econômica da preferência da classe social dominante, ainda que por caminhos distintos. No âmbito da "sociedade civil" as classes sociais procuram consolidar sua hegemonia por meio da conquista de adeptos às suas posições 
mediante a direção política e o consenso; por outro lado, as "sociedades políticas" optam pela imposição da dominação por meio da coerção.

A adequada compreensão da escola/educação no pensamento de Gramsci requer a consideração de um quadro de reflexão teórica mais amplo, situando-o no interior de um movimento voltado a construção de um projeto de transformação social. É em meio a esse cenário que não seria correto com a obra do autor negligenciar um de seus conceitos mais importantes - hegemonia-que, juntamente com os conceitos de sociedade civil, sociedade política, inevitavelmente, interfere nas demais discussões vindouras, especialmente na perspectiva de (re)pensar a escola.

A prisão de Gramsci pelos fascistas italianos (1926-1937), ocorrida em paralelo à derrota do movimento operário italiano, parece ter revelado ao pensador sardo a necessidade de mergulhar nos novos modos de dominação burguesa na Europa Ocidental. Secco (2006) escreve que

\begin{abstract}
A literatura, o jornalismo, o fordismo e outros assuntos aparecem como variantes formais da mesma persistência temática: $a$ hegemonia. É o seu processo de constituição histórica, as suas diferentes maneiras de construir o consentimento nas diversas camadas sociais, os seus diversos mecanismos e funções institucionais que interessam a Antonio Gramsci (p. 47 grifos nossos).
\end{abstract}

O conceito de hegemonia pode ser considerado o principal dos Cadernos do Cárcere, central para a compreensão do Risorgimento italiano. Em linhas gerais, a discussão em torno de hegemonia é oriunda da tradição marxista de discussão das configurações sociais em diferentes contextos espaço-temporais. Gramsci desenvolve uma sólida argumentação sobre hegemonia para pensar as relações sociais sem cair no materialismo vulgar ou no idealismo. O conceito de hegemonia propõe um novo entendimento da relação entre estrutura e superestrutura, ao mesmo tempo em que tenta se distanciar da determinação da primeira sobre a segunda, mostrando a centralidade das superestruturas na análise das sociedades avançadas. Esta teorização gramsciana está inserida num período de questionamento dos limites do alcance da revolução proletária nas sociedades capitalistas avançadas, em meados da década de 1920, momento que vai amadurecer os escritos no cárcere. 
Resta bastante claro que a teorização de Gramsci parte sempre da realidade, de manifestações concretas da história, indicando que a hegemonia não pode ser pensada em abstrato, mas como um processo em permanente constituição. Por conseguinte, o conceito de hegemonia é utilizado por Gramsci para demonstrar como a classe dominante constrói e sustenta seu controle ideológico sobre as classes subalternizadas, ou seja, é um conceito que explicita o domínio intelectual e moral exercido por uma parcela da sociedade através do consentimento ou da coerção. Coutinho (1992) esclarece que naquele período Gramsci avançou em sua reflexão e que estava convencido de que

Para se tornar classe dirigente, para triunfar naquela estratégia de longo alcance, o proletariado não pode se limitar a controlar a produção econômica, mas deve também exercer sua direção político-cultural sobre o conjunto das forças sociais, que por essa ou aquela razão, desse ou daquele modo, se opõem ao capitalismo" (p. 36).

Como já assinalado anteriormente, Gramsci alarga a compreensão de Estado ao não limita-lo ao aparelho estatal, mas considerando-o formado pela combinação sociedade política (identificada com o aparelho de Estado)-sociedade civil, como fica bastante claro quando o pensador escreve que na "noção geral de Estado entram elementos que devem ser remetidos à noção de sociedade civil (no sentido, seria possível dizer, de que Estado $=$ sociedade política + sociedade civil, isto é, hegemonia encouraçada de coerção)" (2017. p. 225). Nesse contexto, o Estado no seio do capitalismo "é certamente concebido como organismo próprio de um grupo, destinado a criar as condições favoráveis à expansão máxima desse grupo" (idem, p. 39), cabendo ao Estado atuar na regulação de equilíbrios entre a classe dominante e as classes subalternas, isto é,

O grupo dominante é coordenado concretamente com os interesses gerais dos grupos subordinados e a vida estatal é concebida como uma contínua formação e superação de equilíbrios instáveis (no âmbito da lei) entre os interesses do grupo fundamental e os interesses dos grupos subordinados. (ibidem)

A formação de equilíbrios é efetivada através do exercício da hegemonia da classe dominante, ou pelo consenso, obtido por meio da difusão de sua ideologia ao longo da sociedade pela utilização de organismos privados de hegemonia, como a escola, a Igreja, os partidos políticos, ou pela coerção. É na análise do chamado 
Risorgimento (a formação do Estado moderno italiano) que Gramsci (2015) apresenta uma síntese do conceito de hegemonia, afirmando que

O critério metodológico sobre o qual se deve basear o próprio exame é este: a supremacia de um grupo social se manifesta de dois modos, como "domínio" e como "direção intelectual e moral". Um grupo social domina os grupos adversários, que visa a "liquidar" ou a submeter inclusive com a força armada, e dirige os grupos afins e aliados. Um grupo social pode e, aliás, deve ser dirigente já antes de conquistar o poder governamental (esta é uma das condições principais para a própria conquista do poder); depois, quando exerce o poder e mesmo se o mantém fortemente nas mãos, torna-se dominante mas deve continuar a ser também “dirigente". (p. 55)

Antes de avançarmos pela "trilha revolucionária" cabe afirmar que a apresentação deste contexto histórico-espacial tem como fito iluminar o papel do Estado como agente construtor e mantenedor da hegemonia burguesa, que passou a se utilizar da incorporação das reivindicações populares e democráticas e de mecanismos de difusão de sua ideologia, estruturando a íntima relação entre a estrutura e a superestrutura que permite a consolidação hegemônica burguesa (GRAMSCI, 2015). Sociedade política e sociedade civil em estreita articulação, próceres em uma relação orgânica que sustenta a dominação burguesa ao combinarem consenso e coerção. Outrossim, emergem do interior da sociedade civil as instituições responsáveis pela gestação e propagação de ideologias em inexorável integração com os intelectuais. O próprio Gramsci (2016) ensina que

Deve-se notar que a elaboração das camadas intelectuais na realidade concreta não ocorre num terreno democrático abstrato, mas segundo processos históricos tradicionais muito concretos. Formaram-se camadas que, tradicionalmente, "produzem" intelectuais; e elas são as mesmas que, com frequência, especializaram-se na "poupança" isto é, a pequena e média burguesia fundiária e alguns estratos da pequena e média burguesia urbana. (p. 18)

Os intelectuais, por conseguinte, podem ser compreendidos como

Os "prepostos" do grupo dominante para o exercício das funções subalternas da hegemonia social e do governo político, isto é: 1) do consenso "espontâneo" dado pelas grandes massas da população à orientação impressa pelo grupo fundamental dominante à vida social, consenso que nasce "historicamente" do prestígio (e, portanto, da confiança) obtido pelo grupo dominante por causa de sua posição e de sua função no mundo da produção; 
2) do aparelho de coerção estatal que assegura "legalmente" a disciplina dos grupos que não "consentem", nem ativa nem passivamente, mas que é constituído para toda a sociedade na previsão dos momentos de crise no comando e na direção, nos quais desaparece o consenso espontâneo. (p. 19)

Para o pensador sardo, todo homem é intelectual ${ }^{42}$, conquanto nem todos exerçam esta função social de difundir a ideologia de uma classe. O grupo de intelectuais é pilar fundamental para a manutenção da hegemonia graças a sua capacidade de promover conteúdos ético-políticos necessários às demandas econômico-sociais do modo de produção capitalista, porquanto a hegemonia nunca é definitiva e exige esforços contínuos para o alcance do consenso pelas classes dominadas. De acordo com esta atribuição é possível compreender os intelectuais como

Por intelectuais, deve-se entender não só aquelas camadas comumente compreendidas nesta denominação, mas, em geral, todo o estrato social que exerce funções organizativas em sentido lato, seja no campo da produção, seja no da cultura e no políticoadministrativo [...]. (GRAMSCI, 2015. p. 81)

Aos intelectuais está reservado não apenas o papel de conservação da hegemonia, como também a elaboração e estruturação de novos programas hegemônicos, tornando imprescindível que a formação de intelectuais seja prenhe de estratégias mobilizadoras da vontade coletiva das classes dominadas. A intelectualidade desenvolve uma "nova consciência" nas classes subalternizadas, isto é, uma nova forma de pensar e agir condizente com os interesses hegemônicos. Esta análise nos conduz novamente ao período revolucionário francês do final do século XVIII, quando, nas palavras do próprio Gramsci (2016),

Um novo agrupamento social aflora politicamente à história, ele está completamente aparelhado para todas as suas funções sociais e, por isso, luta pelo domínio total da nação, sem estabelecer compromissos essenciais com as velhas classes, mas, ao contrário, subordinando-as às próprias finalidades. As primeiras células intelectuais do novo tipo nascem com as primeiras células econômicas [...]. Esta maciça construção intelectual explica a função da cultura francesa nos séculos XVIII e XIX, função de

\footnotetext{
${ }^{42}$ É válido frisar que Gramsci identifica duas formas de intelectuais presentes em uma sociedade: $\mathrm{o}$ chamado "grupo social originário", que nascendo no mundo da produção econômica "cria para si, ao mesmo tempo, organicamente, uma ou mais camadas de intelectuais que lhe dão homogeneidade e consciência da própria função, não apenas no campo econômico, mas também no social e político" (2016. p. 14); e o que se constitui através da incorporação dos intelectuais anteriores, oriundos da formação econômica pré-existente.
} 
irradiação internacional e cosmopolita e de expansão de caráter imperialista e hegemônico de modo orgânico, portanto muito diversa da italiana, de caráter imigratório pessoal e desagregado, que não reflui sobre a base nacional para potenciá-la, mas, ao contrário, concorre para impossibilitar a constituição de uma sólida base nacional. (p. 24)

Ao analisar a realidade italiana no desenvolvimento de uma "classe intelectual" funcionando como sustentáculo de construção hegemônica, Gramsci fornece valiosos subsídios teóricos que validam a importância da escola como espaços de formação dos intelectuais e, por conseguinte, como espaços fundamentais para a conservação da ordem hegemônica e da classe dominante. É bem verdade que o pensador italiano atribui também grande destaque aos partidos políticos, mas considerando nossos objetivos concentraremos nossa atenção na escola, entendida como o "instrumento para formar intelectuais de diversos níveis" (idem. p. 18). Não obstante, a diversificação e distribuição territorial dos diferentes tipos de escola (clássicas e profissionai ${ }^{43}$ ) coadunadas aos diferentes objetivos das classes sociais indicam a constituição dos diferentes ramos de especialização intelectual.

O movimento seguinte do pensador comunista é verificar que a função da escola na sociedade italiana favorecia a manutenção da classe dominante. Ele escreve, de forma bastante assertiva, que "a marca social é dada pelo fato de que cada grupo social tem um tipo de escola próprio, destinado a perpetuar nestes estratos uma determinada função tradicional, dirigente ou instrumental” (p. 45). À guisa apenas de inspiração teórica, cabe reafirmar que Gramsci apresenta como proposta a necessidade de instituição da "escola unitária" com o objetivo de se contrapor ao princípio das escolas diferenciadas entre as classes sociais e por perceber que as escolas são espaços de luta entre interesses de classe. A proposição gramsciana é estabelecer um novo tipo homem, autônomo, livre e dono de sua história, defendendo que

Se se quer destruir essa trama, portanto, deve-se não multiplicar e hierarquizar os tipos de escola profissional, mas criar um tipo único de escola preparatória (primária-média) que conduza o

\footnotetext{
${ }^{43}$ Em sua reflexão teórica Gramsci identificara a coexistência de dois tipos de escolas, "as clássicas e as técnicas: a escola profissional destinava-se às classes instrumentais, enquanto a clássica destinava-se às classes dominantes e aos intelectuais" (2016. p. 30). Naquele mesmo período, o desenvolvimento industrial, tanto na cidade como no campo, estimulou a formação de um novo tipo de intelectual urbano, o que demandou um novo tipo de escola: a escola técnica.
} 
jovem até os umbrais da escolha profissional, formando-o, durante este meio tempo, como pessoa capaz de pensar, de estudar, de dirigir ou de controlar quem dirige. (Ibidem)

Cumpre frisar que para o comunista italiano, a relação pedagógica não está restrita aos espaços escolares, mas permeia toda a sociedade

Através das quais as novas gerações entram em contato com as antigas e absorvem suas experiências e seus valores historicamente necessários, "amadurecendo" e desenvolvendo uma personalidade própria, histórica e culturalmente superior. Esta relação existe em toda a sociedade no seu conjunto e em todo indivíduo com relação aos outros indivíduos, entre camadas intelectuais e não intelectuais, entre governantes e governados, entre elites e seguidores, entre dirigentes e dirigidos, entre vanguardas e corpos de exército. Toda relação de "hegemonia" é necessariamente uma relação pedagógica, que se verifica não apenas no interior de uma nação, entre as diversas forças que a compõem, mas em todo o campo internacional e mundial, entre conjuntos de civilizações nacionais e continentais. (2015. p. $319 / 320)$

As palavras de Gramsci evidenciam a centralidade das relações pedagógicas no desenvolvimento da hegemonia, alçando as instituições escolares, bem como as suas próprias relações, a outro nível de importância. A classe dominante, em luta pela manutenção de sua hegemonia, identificou nos espaços escolares valiosos instrumentos para o exercício de sua dominação, tornando a sua compreensão indispensável. Há nesta proposição um equívoco bastante comum, que é a análise exclusiva dos espaços escolares per si, ou seja, desenvolveu-se como estratégia de compreensão das estruturas hegemônicas as instituições escolares como espaços autônomos, distanciados de suas inexoráveis relações espaciais, bem como perdeuse a dimensão de que as relações pedagógicas não se limitam aos muros ou aos livros escolares, mas estão difundidas pela sociedade

Deste modo, é preciso termos em mente que o estudo desta situação implica na consideração conjunta das relações pedagógicas, da sociedade civil, bem como da ideologia, que aparece como constitutiva das relações sociais, tornando possível a ideia de que tomada do poder e construção de um novo bloco histórico passa pela consideração da centralidade dessas categorias que, até então, eram ignoradas. O desdobramento teórico e prático desta concepção conduz Gramsci (2015) a considerações de cunho ontológico acerca da necessidade de uma auto compreensão crítica de si mesmo, ou seja, 
A consciência de fazer parte de uma determinada força hegemônica (isto é, a consciência política) é a primeira fase de uma ulterior e progressiva autoconsciência, na qual teoria e prática finalmente se unificam. Portanto, também a unidade de teoria e prática não é um dado de fato mecânico, mas um devir histórico, que tem a sua fase elementar e primitiva no sentimento de "distinção", de "separação", de independência quase instintiva, e progride até a aquisição real e completa de uma concepção do mundo coerente e unitária. É por isso que se deve chamar a atenção para o fato de que o desenvolvimento político do conceito de hegemonia representa, para além do progresso político-prático, um grande progresso filosófico, já que implica e supõe necessariamente uma unidade intelectual e uma ética adequada a uma concepção do real que superou o senso comum e tornou-se crítica, mesmo que dentro de limites ainda restritos (p. 83).

O posicionamento ontológico de Gramsci pode ser mais bem compreendido se o discutirmos a partir da retomada de alguns temas centrais discutidos no capítulo anterior. Ao insistirmos na inseparabilidade entre gnosiologia e ontologia podemos perceber que o processo de conhecer é cindido em uma dualidade manifesta na própria cisão do ser social, isto é, entre aparência e essência. As próximas linhas estão dedicadas justamente a apresentarem uma reflexão sobre como a ontologia marxiana, profundamente valorizada por Gramsci, pode colaborar para o devido entendimento desta dimensão estruturante da classe dominante.

\subsection{1. É preciso pensar a ontologia e a ideologia em Gramsci}

A condução do capítulo nos leva a uma necessária reflexão, mais aprofundada, acerca da temática ontológica em Gramsci, cujo foco deve colocar luz sobre a forma de produção dos homens (de consciências) para a consolidação hegemônica da classe dominante.

No capítulo anterior já apresentamos longa discussão sobre as bases teóricas da ontologia, o que nos permite pôr em tela com maior segurança os avanços teóricos obtidos com o rompimento com a dialética hegeliana e a implementação de uma nova concepção dialética de viés ontológico materialista, solo onde Gramsci finca sua teoria. O elemento novo a ser inserido em nosso texto é a busca de compreensão das condições de distinção social e que servem de inspiração à ascensão de classes subalternizadas, ou seja, ganha corpo um processo de transformação de leitura da realidade através da consideração da dimensão histórica 
de formação de sua classe. Este movimento exprime com bastante nitidez a estreita relação existente entre o processo de conhecer o mundo e a existência humana, conferindo grande importância às formas de produção dos sujeitos.

Não é exaustivo reafirmar que, em nosso entendimento, o conhecimento do mundo ocorre de forma inseparável da existência humana (gnosiologia-ontologia). A partir desta premissa, e apoiados pela reflexão de Marx \& Engels (1984), defendemos que o ponto fulcral do conhecimento reside no processo de produção dos homens:

Pode-se distinguir os homens dos animais pela consciência, pela religião ou pelo que se queira. Mas eles mesmos começam a se distinguir dos animais tão logo começam a produzir seus meios de vida, [...]. (p. 27)

A produção intelectual de Gramsci durante o cárcere aborda diferentes questões, tanto de elementos sistemáticos quanto de temas históricos e concretos, que, se, por um lado, nos despertam múltiplos interesses e apontam para algumas possibilidades investigativas, por outro lado, dificultam a estruturação e organização de um caminho sólido para a pesquisa. Destarte, dentre a plêiade de temáticas encontradas, fizemos a opção, sempre pautados por nossos objetivos, de perscrutar a via ontológica desenvolvida pelo comunista sardo que nos reserva elucubrações em torno das determinações dialéticas da sociedade civil, com especial ênfase na construção da práxis humana, justamente porque acreditamos residir nessa discussão fundamentos teóricos consistentes para entender os currículos escolares e os sujeitos cognoscentes em suas expressões ontológicas.

Antes de avançarmos mais detidamente nesta questão ontológica(gnosiológica) é relevante ponderarmos que as teorizações de Gramsci, bastante influenciadas pelo leninismo, encontram lugar nuclear no processo de evolução do marxismo, que é considerado como uma espécie de método para a descoberta de novas determinações a partir "do desdobramento das antigas, as quais - sendo dialéticas - eram determinações necessariamente abertas à evolução histórica, e que exigiam, por isso, uma renovação permanente" (COUTINHO, 1992. p. 49). Por conseguinte, é primaz explicitar que ao longo do devir histórico, em termos ontológicos, as determinações mais simples podem ser reposicionadas e alteradas em determinações mais complexas concretas, o que significa afirmar que a 
novidade não pode ocultar a continuidade. Este caráter dialético presente na leitura que Gramsci realiza de Marx é também uma realidade da interpretação que efetivamos sobre o aspecto ontológico da educação e de suas relações com as estruturas hegemônicas.

A subalternidade (ou a própria hegemonia) consistem, destarte, em condição historicamente construída e, como tal, são concebidos como processos em devir, em transformação. É em meio a essa realidade, reconhecida como inconclusa, que a chamada filosofia burguesa obtém elementos decisivos para sua emergência e, coadunado ao recrudescimento do modo de produção capitalista, considerado como totalidade concreta em permanente desenvolvimento, implica uma necessária compreensão da realidade para poder transformá-la.

Apoiado neste posicionamento, o marxismo, segundo interpretação de Gramsci, deve ser concebido como filosofia da práxis, ideia que será desenvolvida a partir da recuperação da obra de filósofo marxista italiano Antonio Labriola ${ }^{44} \mathrm{e}$ em sintonia com as Teses sobre Feuerbach, estabelecidas sobre a categoria trabalho. Labriola postula as bases ontológicas da filosofia da práxis em decorrência da defesa do trabalho como fundamento da história social do homem.

É a partir desta perspectiva analítica que Gramsci (2015) assevera que para a filosofia da práxis “o ser não pode ser separado do pensar, o homem da natureza, a atividade da matéria, o sujeito do objeto; se se faz esta separação, cai-se numa das muitas formas de religião ou na abstração sem sentido" (p. 138). A filosofia da práxis, por conseguinte, parte da realidade contraditória do mundo, mas rejeita o materialismo vulgar que por vezes tomou conta da corrente marxista e, dentre outras questões, se equivocava ao eliminar de suas reflexões o papel ativo do sujeito (tanto o que atua quanto o que busca entender) na construção da vida social. Nesta

\footnotetext{
${ }^{44}$ É interessante contextualizar a obra de Gramsci em meio ao marxismo italiano do início do século XX, quando se opõe aos marxistas da Segunda Internacional. O filósofo italiano durante seu período no cárcere identificou uma dupla revisão sofrida pela marxismo entre os séculos XIX e XX: “ por um lado alguns seus elementos foram absorvidos das correntes idealistas (Croce, Sorel, Bergson); por um outro, os chamados "marxistas oficiais", preocupados de buscar uma filosofia que compreendesse o marxismo a acharam nas derivações modernas do materialismo filosófico vulgar (como aconteceu com Kautsky) ou no neo-kantismo (é o caso de Eduard Bernstein)" (FRESU, 2016. p. 89). Nesse contexto, segundo Fresu (2016), Gramsci atribuiu a Labriola o mérito de afirmar a natureza independente e original do marxismo como doutrina e que se empenhou para estruturar, em termos científicos, a "filosofia da práxis". Assim, não é mera casualidade que Gramsci utiliza nos Cadernos do Cárcere a definição de Labriola de "filosofia da práxis" para se referir ao materialismo histórico, "explicando a sua visão da realidade social como totalidade e a natureza unitária da relação entre pensamento e ação" (p. 90).
} 
perspectiva, ao sujeito cabe "refletir e registrar uma realidade que se processa independente de sua vontade" (COUTINHO, 1992. p. 60). A filosofia da práxis, por outro lado, está voltada a realçar o sentido original da práxis, da atividade humana em ato (uma relação ontológica), expondo sua vinculação inextricável com o conhecimento (uma relação gnosiológica), ou seja, a "necessidade do conhecimento científico - de um conhecimento que esclareça nexos causais (objetivos) sobre os quais vai operar a teleologia (a iniciativa do sujeito) - resulta da própria natureza da práxis, e é por ela exigida" (p. 60/61).

É possível perceber que a filosofia da práxis é um conceito bastante importante da obra de Gramsci e muito dessa importância deve-se ao fato de explicitar uma nova concepção dialética da práxis, simultaneamente, gnosiológica (voltada ao conhecimento da realidade) e ontológica (imanente ao ser humano, partindo do real por ação do próprio ser social). A razão dialética apresentada permite pensar a unidade entre homem e natureza, de maneira que o sentido da natureza objetivada é captado pela práxis em sua dimensão social e histórica (COUTINHO, 1992). Particularmente no que tange à dialética, o filósofo italiano (2015) assevera que

\begin{abstract}
A função e o significado da dialética só podem ser concebidos em toda a sua fundamentalidade se a filosofia da práxis for concebida como uma filosofia integral e original, que inicia uma nova fase na história e no desenvolvimento mundial do pensamento, na medida em que supera (e, superando, integra em si os seus elementos vitais) tanto o idealismo quanto o materialismo tradicionais, expressões das velhas sociedades. Se a filosofia da práxis é pensada apenas como subordinada a uma outra filosofia, é impossível conceber a nova dialética, na qual, precisamente, aquela superação se efetua e se expressa. (p. 115)
\end{abstract}

A dialética fundante da filosofia da práxis é, portanto, diretamente tributária do pensamento de Marx, cuja expressão é apresentada nas Teses. Logo na primeira Tese, Marx afirma que

$\mathrm{O}$ defeito fundamental de todo materialismo anterior - inclusive o de Feuerbach - está em que só concebe o objeto, a realidade, $\mathrm{o}$ ato sensorial, sob a forma do objeto ou da percepção, mas não como atividade sensorial humana, como prática, não de modo subjetivo. Daí decorre que o lado ativo fosse desenvolvido pelo idealismo, em oposição ao materialismo, mas apenas de modo abstrato, já que o idealismo, naturalmente, não conhece a atividade real, sensorial, como tal. (Edição Kindle, sem datação). 
É bastante evidente o caráter anti-metafísico presente nesta sentença, característica que Gramsci mantém e aprofunda em sua interpretação quando afirma que a filosofia da práxis "continua a filosofia da imanência, mas depurando-a de todo o seu aparato metafísico e conduzindo-a ao terreno concreto da história", ou seja, a ideia de imanência passa agora a estar estritamente vinculada à ação humana concreta, posicionamento presente na segunda Tese: "É na prática que o homem tem que mostrar a verdade, isto é, a realidade, a força, o caráter terreno de seu pensamento. $\mathrm{O}$ debate sobre a realidade ou a irrealidade de um pensamento isolado da prática é um problema puramente escolástico". (Edição Kindle, sem datação)

A partir desta fundamentação teórica marxista e utilizando conceitos já apresentados é possível inferir que Gramsci conseguiu vislumbrar que da relação entre estrutura e superestrutura, permeada pela luta de classes, é necessário saltar para a transformação do mundo, movimento que depende de conhecê-lo. Aqui jaz um problema que merece uma atenção a parte: conhecer e transformar são ações movidas por princípios ideológicos, manifestados nos complexos superestruturais (igrejas, formas jurídicas, educação etc.). A relevância da dimensão gnosiológica na teorização dialética de Gramsci coloca em destaque a ideologia, enquanto ponto de conexão entre teoria e prática, conhecimento e ação (COUTINHO, 1992). Vejamos um pouco melhor esta temática da ideologia.

Coutinho (2010) identificou que o triunfo da burguesia significou, no momento seguinte, a exclusão da classe trabalhadora de qualquer contato com a tradição histórico-filosófica que a permitiu questionar as estruturas feudais e organizar o rearranjo político-econômico implementado através da democracia burguesa e do capitalismo. Não obstante, emerge da crítica gramsciana o conceito de ideologia como fundamento do processo de conhecimento do real, ou seja, se o homem faz parte do processo objetivo da realidade social, todo o conhecimento acerca desse real contém uma ideologia subsistente, refletindo algo que existe fora da consciência e da vontade do sujeito, ou melhor, consiste em projetos que lhes são estranhos, mas que são permanentemente reproduzidos.

Há, assim, um nexo orgânico entre ciência e ideologia, entre conhecimento e práxis, e é justamente neste vínculo ontológico que o marxismo praticado por Gramsci "consiste em ser uma ciência, que ao mesmo tempo e conscientemente, serve de base para a construção de uma ideologia, de uma concepção de mundo, de 
uma práxis política" (COUTINHO, 1992. p. 61). Outrossim, todo o conhecimento científico tem um aspecto historicamente relativo, uma vez que seu teor de objetividade é dependente das condições históricas, dos objetivos historicamente definidos que a práxis se propõe e pode alcançar. Neste momento é interessante coadunar à esta discussão o pensamento de Lukács (2013) que justamente desenvolvendo uma crítica a Gramsci escreve que

A ideologia é sobretudo a forma de elaboração ideal da realidade que serve para tornar a práxis social humana consciente e capaz de agir. Desse modo, surgem a necessidade e a universalidade de concepções para dar conta dos conflitos do ser social. (p. 335)

A adoção de Lukács nos impele a considerar sua perspectiva analítica ontológica-genética da ação humana oriunda do trabalho, entendido como um processo entre atividade humana e natureza, "seus atos estão orientados para a transformação de objetos naturais em valores de uso", e, por conseguinte, a partir dos condicionantes históricos, "nas formas ulteriores e mais desenvolvidas da práxis social, destaca-se em primeiro plano a ação sobre outros homens, cujo objetivo é, em última instância [...], uma mediação para a produção de valores de uso. (p. 62). A “ação sobre outros homens" sugere a necessidade de elaboração de formas de convencimento suficientemente capazes de atrair um grupo de sujeitos a uma ideia e robustecer sua prática pela aceitação coletiva. A sequência do raciocínio de Lukács é enriquecedor ao apresentar que "o conteúdo essencial do pôr teleológico nesse momento - falando em termos inteiramente gerais e abstratos - é a tentativa de induzir outra pessoa (ou grupo de pessoas) a realizar, por sua parte, pores teleológicos concretos", problema que surge imediatamente quando "o trabalho se torna social, no sentido de que depende da cooperação de mais pessoas, independente do fato de que já esteja presente o problema do valor de troca ou que a cooperação tenha apenas como objetivo os valores de uso" (Ibidem).

Entendemos residir nesta constatação a urgência em conhecer do modo mais objetivo possível as estruturas hegemônicas, as determinações históricas da ação humana que permitem uma outra práxis. É a este tipo específico de conhecimento que Gramsci se refere como ideologia, conhecimento que mobiliza a consciência de forma a contribuir decisivamente para a compreensão ontológica da práxis. Coutinho (1992) traz valiosas palavras acerca desta discussão quando escreve que a adoção deste caminho apresentado permite a superação de "uma visão puramente 
gnosiológica da ideologia, que a vê apenas como "falsa consciência"” e, ao mesmo tempo, estimula a sua compreensão enquanto "realidade prática, enquanto fenômeno ontológico-social” (p. 65).

O profícuo diálogo entre Gramsci e Lukács nos mostra que a ação sobre o outro pressupõe o estabelecimento de algum tipo de diálogo com a consciência dele, ou seja, não basta apenas que haja conhecimento científico objetivo, mas a efetivação de projetos teleológicos demanda o convencimento do outro a agir da forma desejada. Assim, segundo Coutinho (1992), “os conteúdos de consciência que utilizo nesse tipo de ação não tem eficácia apenas [...] enquanto reproduzem o real, enquanto são ciência; o que importa é que convençam o outro e o levem à ação [...]” (p. 64) $)^{45}$. Esta consideração encontra firme suporte quando Lukács (2013) afirma que, segundo o próprio Marx, “a forma mais geral da essência assume para com suas realizações concretas na práxis do mundo fenomênico - também no mundo econômico e principalmente no ideológico - uma relação de possibilidade, de campo de ação concreto de possibilidade” (p. 287).

Para nós, neste momento, é inevitável recorrer, mais uma vez, ao trabalho de Santos (2006) que discorre acerca de um mundo latente, que se dá como um conjunto de possibilidades, tendências reais que vagam entre objetos e fenômenos, até que sejam chamadas a se realizar. Não obstante, tais essências seriam o "Real Possível, possibilidades reais, e não ideais" (p. 123). Outrossim, "as existências são manifestações particulares do Ser: este geneticamente precede a existência, como fonte de sua possibilidade" (p. 124) e estas possibilidades reais se tornam realizadas por meio da ação, vínculo que une o Universal e o Particular no lugar. As palavras de Santos abrem caminho para que possamos refletir com maior segurança sobre a práxis humana, ou seja, a produção e reprodução do homem (e do espaço), transformando em realidade aquilo que era possibilidade. Não é de outra forma, que Marx (2011) esclarece definitivamente esta discussão ao ensinar que

Se consideramos a sociedade burguesa em seu conjunto, a própria sociedade, i.e., o próprio ser humano em suas relações

\footnotetext{
${ }^{45}$ Esta proposição parece encontrar guarida no pensamento de Lukács (2013) em torno de juízos equivocados realizados pela corrente marxista, que funda sua metodologia a partir da Segunda Internacional, acerca da dinâmica real da esfera econômica. Para o pensador húngaro, aquela corrente desconsidera o significado da economia no contexto global do ser social, compreendendoa como uma espécie de segunda natureza, distante em termos de estrutura e de dinâmica das demais esferas do ser social, da chamada superestrutura, da ideologia.
} 
sociais, sempre aparece como resultado último do processo de produção social. Tudo o que tem forma fixa, como o produto etc., aparece somente como momento, momento evanescente nesse movimento. O próprio processo de produção imediato aparece aí apenas como momento. As próprias condições e objetivações do processo são igualmente momentos dele, e somente os indivíduos aparecem como sujeitos do processo, mas os indivíduos em relações recíprocas, relações que eles tanto reproduzem quanto produzem de maneira nova. É seu próprio contínuo processo de movimento, em que eles renovam a si mesmos, bem como o mundo da riqueza que criam. (p. 951/952)

Portanto, tomando como verdade a proposição do marxismo de que os próprios homens fazem a sua história, mas não podem fazê-la nas circunstâncias escolhidas por eles, na realidade os homens respondem "às alternativas concretas [possibilidades] que lhes são apresentadas a cada momento pelas possibilidades do desenvolvimento social” (LUKÁCS, 2013. p. 90), é possível conceber que a filosofia da práxis tem a tarefa de realizar a crítica das concepções de mundo confusas e contraditórias, marcadas por elementos "egoístico-passionais", corporativistas, individualistas.

Na visão de Gramsci (2015), é tarefa precípua desenvolver uma "reforma intelectual e moral" capaz de difundir entre a sociedade uma nova cultura que contribua para uma transformação radical. Após toda esta reflexão, resta óbvio que o pensador italiano identificou na história da sociedade a luta de classes e que a libertação das classes dominadas pressupõe a apropriação do conhecimento historicamente negado e é aí que a filosofia da práxis cumpre papel central. Cabe ainda salientar que para Gramsci a ideologia é algo que transcende ao conhecimento e está diretamente atrelada à ação, voltada a influenciar no comportamento dos homens, consistindo, destarte, em intermédio entre a concepção da construção de mundo e a batalha pela hegemonia. Em suas próprias palavras:

A compreensão crítica de si mesmo é obtida, portanto, através de uma luta de "hegemonias" políticas, de direções contrastantes, primeiro no campo da ética, depois no da política, atingindo, finalmente, uma elaboração superior da própria concepção do real. (2015. p. 83)

Porquanto, se a ideologia, segundo a perspectiva gramsciana, consiste em fato ontológico é correto pensarmos, de acordo com Coutinho (1992), que ela altera a vida humana, mesmo quando seus conteúdos cognitivos não condizem com a reprodução da realidade. Dada essa importância ontológica, Gramsci identifica duas 
vertentes ideológicas: de um lado, as chamadas "ideologias orgânicas" organizam "as massas humanas, formam o terreno no qual os homens se movimentam, adquirem consciência de sua posição, lutam, etc." e, por outro lado, as "ideologias arbitrárias” não “criam mais do que "movimentos' individuais, polêmicas, etc." (p. 183). Neste sentido, a filosofia da práxis, o marxismo (COUTINHO, 1992), seria tal qual uma "ideologia orgânica", ou seja, uma realidade ontológico-social de grande relevância para as transformações sociais.

\subsection{A crítica da educação}

Após toda a discussão empreendida e de posse de algumas ideias estruturantes do pensamento gramsciano é possível avançarmos para uma abordagem prioritariamente voltada às questões educacionais. Partindo da luta de classes que se desenvolve em meio a relação entre estrutura e superestrutura emerge a importância do conhecimento para embasar qualquer movimento de transformação social, movimento que é fertilizado por ideologia (orgânica), e que se manifesta de diferentes formas, inclusive na educação. A ideologia, ao assumir posição nuclear na dimensão gnosiológica, conecta teoria e prática, conhecimento e ação, todavia sua atuação pode resultar em diferentes funções sociais, como conciliador dos interesses dominantes ou transformador, em sintonia com a própria filosofia da práxis.

A passagem dessa possibilidade para a realidade se concretiza, na perspectiva de Gramsci (2015), a partir das instituições da sociedade civil, nos aparelhos hegemônicos, que organizam e difundem o consenso pelo controle das atividades políticas, culturais e intelectuais das massas. É dessa forma que se concretiza a feição educativa da filosofia da práxis que o próprio Gramsci, ao analisar na introdução da Crítica da economia política de Marx a proposição de que os homens tomam consciência dos conflitos de estrutura no terreno das ideologias. Ele afirma que

Disto decorre que o princípio teórico-prático da hegemonia possui também um alcance gnosiológico; e, portanto, é nesse campo que se deve buscar a contribuição teórica máxima de 
$\mathrm{Ilitch}^{46}$ à filosofia da práxis. Ilitch teria feito progredir efetivamente a filosofia como filosofia na medida em que fez progredir a doutrina e a prática política. A realização de um aparelho hegemônico, enquanto cria um novo terreno ideológico, determina uma reforma das consciências e dos métodos de conhecimento, é um fato de conhecimento, um fato filosófico. (p. 258)

Desta constatação importa desvendar a articulação existente entre a estrutura e superestrutura, justamente onde reside a contradição fundamental entre as forças produtivas e as relações de produção. Gramsci (idem) é bastante explicativo ao assegurar que

A estrutura e as superestruturas formam um "bloco histórico", isto é, o conjunto complexo e contraditório das superestruturas é o reflexo do conjunto das relações sociais de produção. Disto decorre: só um sistema totalitário de ideologias reflete racionalmente a contradição da estrutura e representa a existência das condições objetivas para a subversão da práxis. (p. 195/196)

Nesse sentido, segundo nosso entendimento, a hegemonia é tornada "alvo gnosiológico" da filosofia da práxis por representar um conjunto complexo e contraditório a ser transformado pela práxis (política), ou seja, uma mudança radical do mundo é assim possível quando conhecimento e ideologia se alinham, conforme está colocado na décima segunda Tese: “os filósofos não fizeram mais que interpretar o mundo de forma diferente; trata-se porém de modifica-lo" (Edição do Kindle, sem datação). Não é de outra forma que entendemos ser possível alcançar a proposição de Williams (2011), segundo a qual a hegemonia não deve ser única, mas, ao contrário, "suas próprias estruturas são complexas e devem ser renovadas, recriadas e defendidas de forma contínua; podem ser constantemente desafiadas e, em certos aspectos modificadas” (p. 52). Esta proposição além de nos colocar em sintonia com o princípio dialético apresentado impulsiona uma aproximação com nossa perspectiva de abordagem da instituição escolar através da investigação curricular.

É assim que entendemos nos distanciar de qualquer ideia ou algo que possa sugerir que estejamos defendendo um viés mecanicista entre o que chamamos de classe dominante e suas estratégias de dominação implementadas pelas instituições

\footnotetext{
${ }^{46}$ Ilitch é uma das formas de referência que Gramsci utiliza para Lênin (pseudônimo de Vladimir Ilitch Ulianov) com o objetivo de escapar da censura imposta pelos dirigentes carcerários.
} 
escolares. De outro modo, é necessário desqualificar todas as possibilidades explicativas que induzam a compreensão do exercício hegemônico através da difusão de práticas, significados e valores como um sistema mecânico de funcionamento ordenado. Na realidade, a partir de nossa perspectiva dialética, a hegemonia subsiste em consonância a um "sistema central, efetivo e dominante de significados e valores", ou seja,

\begin{abstract}
A hegemonia constitui, então, um sentido de realidade para a maioria das pessoas em uma sociedade, um sentido absoluto por se tratar de uma realidade vivida além da qual se torna muito difícil para a maioria dos membros da sociedade mover-se, e que abrange muitas áreas de suas vidas. Mas não se trata, de forma alguma, de um sistema estático, exceto na execução de um momento de uma análise abstrata. (p. 53)
\end{abstract}

Por conseguinte, delineia-se uma abordagem mais ampla (e complexa) da temática em tela, estruturando uma compreensão da hegemonia a partir dos sistemas estruturais prevalecentes, que Apple (2006) identifica como as maneiras fundamentais pelas quais "as instituições, as pessoas e os modos de produção, distribuição e consumo são organizados e controlados”. Destarte, “dominam a vida cultural. Isso inclui práticas do cotidiano, como as escolas e o ensino e os currículos que adotam" (p. 36). O desafio que se apresenta consiste em investigar a mediação ideológica realizada pela instituição escolar através do currículo de Geografia na formação da consciência dos sujeitos cognoscentes.

É interessante assinalarmos que a análise conjunta da relação estruturasuperestrutura também revela a preocupação de Gramsci em ampliar a compreensão da economia para além das questões meramente produtivas ${ }^{47}$. Qualquer movimento

\footnotetext{
47 Acerca desta questão, e recuperando parte da discussão anterior, acreditamos ser relevante trazermos à tona o pensamento de Lukács (2013), que de modo bastante didático expõe a indispensável necessidade, por vezes ocultada, de pensar e entender a economia para além dos aspectos estritamente econômicos quando se propõe qualquer projeto de transformação radical da sociedade. Ele escreve que "é justamente nas revoluções que o fato de os próprios homens fazerem sua história adquire sua figura mais desenvolvida, mais adequada. As perguntas centrais formuladas de modo marcante conferem ao "ser que responde" um ímpeto para a estruturação do mundo e, mediada desse modo, para a estruturação de si mesmo, que é impossível que pudesse ter possuído no cotidiano normal, mesmo em união, quanto menos isoladamente. Nas grandes crises, tal atividade das pessoas faz surgir um mundo fenomênico socialmente existente que, em seu desenvolvimento posterior, pode vir a ser cada vez mais adequado ao progresso objetivo da essência. Ora, essa adequação de modo algum é imaginada apenas no sentido diretamente econômico. Uma grande revolução econômica, sobretudo a transição de uma formação para a outra, providencia por si mesma que as formas de atividade humana (e, com elas, a constituição que a embasa socialmente) se adaptem às novas relaçôes de produção." (p. 378/379 grifos nossos)
} 
de transformação social, como também nos ensina Lukács, é tributário desta ampliação porquanto, conforme questiona o comunista sardo (2017)

Pode haver reforma cultural, ou seja, elevação civil das camadas mais baixas da sociedade, sem uma anterior reforma econômica e uma modificação na posição social e no mundo econômico? É por isso que uma reforma intelectual e moral não pode deixar de estar ligada a um programa de reforma econômica; mais precisamente, o programa de reforma econômica é exatamente o modo concreto através do qual se apresenta toda reforma intelectual e moral. (p. 18)

Coerente com essa preocupação, coadunamos o pensamento de Apple (2006) que ao pontuar a íntima relação entre educação e o setor econômico reproduzindo aspectos importantes sobre desigualdade - também argumenta acerca do poder difusor da propriedade simbólica que as escolas preservam e distribuem. É por esta via investigativa que se torna possível entender

\footnotetext{
Mais perfeitamente como as instituições de preservação e distribuição cultural, como as escolas, criam e recriam formas de consciência que permitem a manutenção do controle social sem a necessidade de os grupos dominantes terem de apelar a mecanismos abertos de dominação. (p. 37)
}

A potência do pensamento de Gramsci se faz sentir, em grande medida, quando percebemos com maior clareza a impossibilidade de pensar um novo modo de vida sem transformar a ação humana, ou seja, uma nova realidade social somente emerge da organização e da luta no âmbito da estrutura e da superestrutura, da produção e da ideologia, enfim do movimento conjunto de forças subversivas político-econômicas para o estabelecimento de uma outra hegemonia. Por conseguinte, a filosofia da práxis adquire caráter educativo, pedagogia subversiva que encontra terreno hostil nas políticas escolares implementadas pelo Estado burguês ao longo da história. É graças a este entendimento que optamos por analisar os currículos oficiais, documentos que expressam o que é planejado e determinado pelo Estado, sendo modificado historicamente para atender a realidades sociais distintas, a tempos e espaços específicos.

Por fim, antes de avançarmos à seção seguinte é imprescindível reafirmar que compreendemos a educação, ou, de forma mais apropriada, a instituição escolar, como uma agente social pertencente ao grande grupo de instituições difusoras de recursos. Portanto, dirigimos nosso olhar para as conexões e laços 
complexos que dotam de significados a organização da sociedade, colocando em primeiro plano o fato de que as próprias relações são definidoras da sociedade. Tomamos emprestados, mais uma vez, a colaboração de Apple (idem) para sustentar este posicionamento quando escreve que, neste contexto, o entendimento das noções de ciência (relacionado ao conhecimento, à gnosiologia) e ao indivíduo (ao aspecto humano, ontológico) do modo que as empregamos na educação, precisam ser vistas primeiramente como

Categorias ideológicas e econômicas que são essenciais tanto para a produção de agentes que preencham os papeis econômicos existentes, quanto para a reprodução de disposições e significados que "causarão", nesses próprios agentes, a aceitação desses papéis alienantes sem muito questionamento. Eles se tornam, então, aspectos da hegemonia. (p. 44)

O passo seguinte em nossa pesquisa, portanto, está ancorado nesta perspectiva dialética de apreensão do sujeito (cognoscente) a partir das premissas dialéticas que regem a organização da sociedade através da ação hegemônica difundida pela instituição escolar e que se manifesta formalmente na elaboração dos currículos oficiais, nos importando desvelar o conteúdo ideológico latente nos documentos de Geografia. Cumpre ressaltar que a procura por este conteúdo ideológico nos documentos curriculares é condição para que enxerguemos o sujeito em seu processo de constituição em meio a totalização da realidade, ou seja, tentamos posicionar o sujeito como um modo da totalidade, como uma maneira de ser, reproduzindo o Todo ao existir enquanto realidade em relação ao Todo.

Esta tarefa será iniciada no item seguinte, com a delimitação de um quadro geral acerca do currículo e de sua discussão acadêmica. No momento seguinte, de acordo com o referencial argumentativo da questão curricular apresentado, será possível adentrar com maior segurança no debate teórico-crítico que, acreditamos, permitirá arguir o sujeito cognoscente da maneira que pretendemos. É nessa direção que caminhamos.

\subsubsection{O Currículo escolar em discussão}

É sabido que apenas na Idade Média e na Europa a educação figurou como produto da escola e um conjunto de pessoas, normalmente religiosos, se 
especializou na transmissão do saber. Assim, houve a destinação de espaços exclusivos, cuidadosamente isolados do mundo dos adultos e sem qualquer relação com a vida de todo dia, para que as elites aprendessem. Os colégios passaram a consistir numa instituição de grande importância para a sociedade por concentrarem um corpo docente próprio, uma rigorosa disciplina em que se formavam todas as gerações instruídas do antigo regime.

Nesse contexto, a "escola da nobreza" cultuava o passado, atribuindo importância primária à moral e à religião, ao domínio da palavra e ao saber abstrato. O conhecimento científico, por conseguinte, era menos importante do que o espírito contemplativo e o latim, símbolos da tradição a ser preservada e considerada imune a qualquer transformação. A cultura enciclopédica, refinada e erudita, combinava harmonicamente com o berço dos estudantes e correspondia às suas aspirações, o que significava para estes sujeitos, herdeiros da aristocracia, que se educar era sinônimo de aprender a ser e se comportar como grandes senhores (HARPER et al. 1987). Tal situação só foi em parte modificada justamente no século XIX, como veremos melhor mais a frente.

Não é mera coincidência que o projeto escolar burguês de Estado se firme ao longo do século XIX, quando também ocorre a consolidação da figura do Estado nacional e do capitalismo, sob a égide do próprio pensamento burguês. Politicamente dominante, a burguesia percebe que pode permanecer no poder não apenas por intermédio do poder repressivo, mas também com a difusão de seus valores e ideias de classe apresentados como universais. A implantação de um sistema escolar ao longo de diversos territórios europeus define uma perspectiva de legitimação do Estado-nação, tornando imprescindível a imposição da nacionalidade. A disseminação de valores e símbolos relacionados a um nacionalismo patriótico justifica-se pela necessidade de construir uma identidade nacional capaz de anular as diferenças e forjar uma unidade social entre os que nasceram no mesmo lugar, falam a mesma língua e respeitam as mesmas tradições, mascarando a divisão de classes.

O pensamento gramsciniano, adotado por vários pensadores da chamada teoria crítica do currículo que será melhor apresentada mais a frente, nos permite perceber que a escola contribuiu e ainda contribui, invariavelmente, ao menos de duas formas para o processo de reprodução da formação social capitalista: de um 
lado, reproduzindo as forças produtivas e, por outro lado, as relações de produção já existentes. É o próprio Marx (1996), acerca deste tema, quem nos ensina que

A relação capitalista pressupõe a separação entre os trabalhadores e a propriedade das condições da realização do trabalho. Tão logo a produção capitalista esteja de pé, ela não apenas conserva essa separação, mas a reproduz em escala cada vez maior. O processo que cria a relação capitalista não pode ser senão o processo de separação entre o trabalhador e a propriedade das condições de realização de seu trabalho, processo que, por um lado, transforma em capital os meios sociais de subsistência e de produção e, por outro, converte os produtores diretos em trabalhadores assalariados (p. 340).

É a partir desta constatação que a escola passa a consistir num mecanismo de reforço da própria relação capitalista. Nesse contexto, é fundamental ter em mente que

Não basta que as condições de trabalho apareçam num polo como capital e no outro como pessoas que não têm nada para vender, a não ser sua força de trabalho. Tampouco basta obrigá-las a se venderem voluntariamente. No evolver da produção capitalista desenvolve-se uma classe de trabalhadores que, por educação, tradição e hábito, reconhece as exigências desse modo de produção como leis naturais e evidentes por si mesmas. A organização do processo capitalista de produção desenvolvido quebra toda a resistência; [...] (MARX, 1996. p. 358 grifos nossos).

A proposição acima exibe uma situação que adquiriu contornos bastante nítidos na Europa do século XIX, quando proliferaram, por exemplo, na GrãBretanha as chamadas Schools of Industry ou Colleges of Labour, instituições que funcionaram para educar crianças pobres com base na disciplina e nos hábitos necessários para o trabalharem posteriormente (ENGUITA, 1989). Situação semelhante também pode ser observada na França, país que inspirou a constituição e organização do sistema escolar brasileiro, onde as crianças internadas em hospícios e outras instituições eram vistas como mão de obra barata para as atividades industriais. Relatório elaborado pelo diretor do Bureau des Hospices Civils ao Ministério do Interior alertava que

O governo deve estímulo e proteção às manufaturas. Deve empregar todos os meios a seu alcance para conseguir-lhes os braços necessários para seus trabalhos. 
É no interesse das crianças: são preparadas para trabalhos que, em uma idade mais avançada, poderão proporcionar-lhes meios de existência; são arrancados da ociosidade; são minorados os inconvenientes que a permanência nos orfanatos sempre trouxe para a sua moralidade (FLANDRIN, 1982. p. 75 apud ENGUITA, 1989. p. 110).

É interessante percebermos que naquele período novecentista o pensamento corrente da burguesia em ascensão se equilibrava entre oferecer educação às classes populares para preparar e garantir o seu próprio poder, como também reduzir o papel da igreja e motivar a aceitação da nova ordem; e o temor de que uma classe detentora de conhecimentos pudesse reivindicar mudanças na estrutura social em construção (Ibidem). De acordo com esse "receio", muitos pensadores franceses eram contrários à universalização da educação e afirmavam categoricamente que "o bem da sociedade exige que os conhecimentos do povo não se estendam além de suas ocupações" (CHARLOT \& FIGEAT, 1985 apud ENGUITA, 1989. p. 111).

O desenvolvimento sistema escolar ao longo do século XIX, em consonância com outro projeto escolar (de cunho burguês), não ocorre somente em decorrência das transformações políticas e econômicas, mas também é produto da renovada episteme científica moderna predominante na cultura ocidental. O final do século XVIII foi o período de transformações na ciência e, particularmente para as chamadas "ciências humanas", na tentativa de se encaixarem nos ditames do conhecimento positivista. O procedimento mais corriqueiro foi a busca de sua aproximação das matemáticas, ou seja, "matematizando" todo o possível e considerando tudo o que não é suscetível à semelhante conduta como ainda carente de um tratamento científico positivo (FOUCAULT, 1987).

Esta análise de Foucault, coadunada ao quadro histórico geral apresentado acima, nos serve de base para iniciar uma reflexão crítica do currículo, delineando com bastante cuidado nossas premissas investigativas acerca desta temática. Assim, nossa proposta parte do fato de que currículo é um espaço de poder e, por conseguinte, representa uma disputa pela produção da verdade. A sociedade é atravessada por uma multiplicidade de relações de poder que caracterizam e constituem o corpo social e que não podem se estabelecer "nem funcionar sem uma produção, uma acumulação, uma circulação e um funcionamento do discurso", discurso que apresenta aquilo que é tido como verdade, uma vez que "o poder não para de nos interrogar, de indagar, registrar e institucionalizar a busca da verdade, 
profissionaliza-a e a recompensa" (FOUCAULT, 2007. p. 179/180). É interessante agregar à discussão o pensamento de Badiou (1994), outro filósofo francês, que, acerca da verdade, afirma: "uma verdade é primeiramente uma novidade" e correlaciona esta ideia com a filosofia moderna, questionando: se toda verdade é uma novidade, "qual o problema da filosófico essencial da verdade? É o problema de sua aparição e de seu devir. É preciso pensar a verdade não como um juízo, mas como um processo real" (p. 44).

O currículo escolar, em última instância, funciona como o "documento da verdade", ou seja, o parâmetro que define como e qual "verdade" deve ser ensinada, todavia o conhecimento corporificado no currículo não é algo fixo, mas um artefato social e histórico, em permanente condição de fluxo e de transformação. O currículo, como por exemplo os PCNs de Geografia do ensino médio, é resultado de um profundo processo de lutas e conflitos entre diferentes tradições e concepções sociais. Não obstante, a construção de um "documento da verdade a ser ensinada" não se resume enquanto um processo lógico, mas é um processo social, "no qual convivem lado a lado como fatores lógicos, epistemológicos, intelectuais, determinantes sociais menos 'nobres' e menos 'formais', tais como interesses, rituais, conflitos simbólicos e culturais [...]” (SILVA, 2005. p. 8). Destarte, ainda segundo Silva, “o currículo não é constituído de conhecimentos válidos, mas de conhecimentos considerados socialmente válidos" (Ibidem) num determinado momento e em uma determinada sociedade.

A instituição escolar é território político por excelência, resguardando através do currículo, um genuíno sistema ideológico a ser adequadamente reproduzido. O mesmo Silva

A escola atua ideologicamente através de seu currículo, seja de forma mais direta, através das matérias mais suscetíveis ao transporte de crenças explicitas sobre a desejabilidade das estruturas sociais existentes como [...] História e Geografia, por exemplo; seja uma forma mais indireta, através de disciplinas mais "técnicas", como Ciências e Matemática. Além disso, a ideologia atua de forma discriminatória: Ela inclina as pessoas das classes subordinadas a submissão e a obediência, enquanto as pessoas das classes dominantes aprendem a comandar e controlar (2005, p. 31-32).

Esta realidade nos impele a reforçar nossa proposta com as palavras de Marx e Engels (1984), que asseguram serem as ideias dominantes nada mais do que a 
“expressão ideal das relações materiais dominantes", portanto "a expressão das relações que tornam uma classe a classe dominante" (p. 72). Não obstante, prosseguem os filósofos,

Os indivíduos que constituem a classe dominante possuem, entre outras coisas, também consciência e, por isso, pensam, na medida em que dominam como classe e determinam todo o âmbito de uma época histórica, é evidente que o façam em toda a sua extensão e, consequentemente, entre outras coisas, dominem também como pensadores, como produtores de ideias; que regulem a produção e a distribuição das ideias de seu tempo e que suas ideias sejam, por isso mesmo, as ideias dominantes da época. (Ibidem)

Esta premissa nos dirige diretamente a pensar que o currículo é pensado para ter efeitos sobre as pessoas porquanto a escola não lida apenas com conhecimentos, mas com a relação entre estes conhecimentos e as consciências individuais. Nesta perspectiva o currículo se configura não apenas como expressão ou representação de interesses sociais determinados, mas também por produzir identidades e subjetividades sociais determinadas. Essa constatação se aplica tanto ao presente quanto ao pretérito.

Nosso intuito principal, após contextualizar a temática, é apresentar as principais correntes analíticas curriculares e explicitar aquela que utilizaremos, bem como realizar uma análise crítica deste documento, tomando como referência os documentos oficiais de Geografia para o ensino médio. Nesse contexto, apresentaremos a seguir as principais teorias curriculares que darão suporte ao nosso estudo e, no momento seguinte, dedicaremos maior atenção aos referidos documentos.

Diversos estudos já se debruçaram sobre diretrizes pedagógicas nacionais, em diferentes períodos de nossa história. Tal fato nos ajuda muito porque temos ao nosso dispor farto material de pesquisa desenvolvido por diferentes áreas do conhecimento, de enfoques teóricos variados, permitindo uma ampla visualização destes documentos, assim como possibilidades de diálogos. Por conseguinte, a opção pelo estudo do currículo escolar é resultado de um longo processo de maturação investigativa, em que se verificou que a maneira mais adequada de vislumbrar os objetivos políticos e ideológicos do projeto escolar burguês nos sujeitos cognoscentes seria por meio desta via. Nesse sentido, é possível inferir que 
os currículos constituem legítimos retratos do projeto escolar burguês, bem como servem como diretriz a todos educadores por meio da normatização de alguns aspectos fundamentais concernentes a cada disciplina.

Cientes dessas considerações preliminares, é possível iniciarmos uma breve apresentação das ideias e concepções relacionadas ao currículo a luz de alguns autores renomados, que serão devidamente citados e reconhecidos ao longo da explanação. O vocábulo currículo carrega uma série de definições ${ }^{48}$, uma verdadeira polissemia, que segundo Candau \& Moreira (2006), advém das diferentes formas de como a educação é concebida historicamente, como também pelas influências teóricas produzidas e que se tornam periodicamente predominantes. Dentre as diversas acepções, o currículo pode se referir a um elenco de disciplinas e conteúdos organizados de forma sistemática, ou como um agrupamento de estratégias voltadas para o preparo ao mundo do trabalho, ou também como um conjunto de atividades e experiências para alcançarem os fins da educação, significando, por conseguinte, a definição de objetivos e a seleção, organização e avaliação dos conteúdos escolares.

As supracitadas autoras também asseveram a interferência dos fatores socioeconômicos, políticos e culturais na compreensão diversificada do currículo escolar, consistindo num espinhoso campo de interesses sociais e culturais. A partir desta perspectiva e como construção cultural, o currículo reflete uma maneira de organizar as práticas educativas, retratando as funções sociais da escola num determinado período histórico.

Uma das concepções mais predominantes de currículo é a que o considera como um grande "organizador de conteúdos". Ao pensarmos o currículo como uma espécie "guia de conteúdos" estamos fazendo referência aquilo que Sacristán (2020) chama de "currículo prescrito" ${ }^{49}$. Em todo sistema oficial de ensino existe

\footnotetext{
${ }^{48}$ É bastante comum em praticamente todas as obras consultadas a apresentação do sentido etimológico da palavra currículo. Dessa forma, apenas para não deixar de mencionar, este termo é originado do latim scurrere, correr, e se refere a curso, carreira, um percurso a ser realizado. Cabe ainda registrar que este termo será utilizado pela primeira vez relacionado à educação em 1633 no Oxford english dictionary para designar um plano estruturado de estudos (GOODSON, 2008).

${ }^{49} \mathrm{O}$ "currículo prescrito" quando implementado sofre diversas alterações, direta e indiretamente, por professores e estudantes, ou melhor, no dia a dia se desdobram diversas manifestações não previstas no currículo formal que somadas às ações docentes e discentes compõem o chamado currículo vivido ou "currículo em ação" (SACRISTÁN, 2020). Este "currículo em ação" simboliza o currículo na prática real, alterado pelos complexos intercâmbios de influências e interações que, ao final, ultrapassa os propósitos iniciais.
} 
algum tipo de norma ou orientação acerca dos conteúdos, principalmente no que se refere às etapas obrigatórias da educação. Assim, o "currículo prescrito" abrange os aspectos que servem de baliza para a ordenação curricular, oferecendo parâmetros para a elaboração de materiais, formas de controle etc. Cabe lembrar que o currículo transcende a mera atividade técnica, pois ao longo do seu processo de construção são mobilizadas ideologias que permeiam todo o documento e dotam de nítido viés político e cultural, evidenciando relações de poder, concepções de sociedade, da escola e do conhecimento.

Convém afirmar que estas visões estão justapostas e que, em nosso caso, o conceito de currículo oficial constitui-se na prescrição legal da organização das disciplinas a serem trabalhadas pela escola e demais orientações, tais como de conteúdo, didáticas e avaliativas (ZOTTI, 2004). Goodson (2008) chama o currículo oficial (ou prescrito) de currículo escrito e o considera um legítimo testemunho, uma fonte documental, em suma, "um dos melhores roteiros oficiais para a estrutura institucionalizada da educação" (p. 21). Reside nestas constatações a definição dos PCNs de Geografia para o ensino médio como materiais de investigação porquanto consistem, sobretudo, em registros históricos que revelam a intencionalidade do projeto escolar de Estado burguês, ou melhor, a ideologia que fundamenta o trabalho a ser desenvolvido na consciência dos sujeitos cognoscentes.

A discussão em torno do currículo é bastante complexa e está envolta em diversas perspectivas analíticas. Em nosso caso, entendemos ser importante acentuar que este conceito é tido como primordial para a compreensão da prática educativa institucionalizada e das funções da escola porquanto o currículo supõe a concretização dos fins sociais e culturais da educação escolarizada. É o currículo, segundo o próprio Sacristán (2020), que promove uma instrumentalização concreta da escola a partir dos interesses da classe dominante. Não obstante, o currículo não pode ser visto como uma realidade abstrata marginalizada do sistema educativo, uma vez que o estudo do currículo permite observar a concretização das funções da própria escola de acordo com o momento histórico e social determinado.

É de acordo com estas ideias que abordamos o currículo como expressão do equilíbrio de interesses e de forças que circundam o sistema de ensino em um dado momento, materializando, através dos conteúdos e das formas que se apresenta a professores e alunos, uma opção historicamente sedimentada e inserida no amplo 
contexto socioeconômico e político. A adoção desta via analítica nos coloca em diálogo com as chamadas "teorias críticas do currículo" 50 , ou seja, não há conhecimento neutro, puro, mas todo o conhecimento presente neste documento carrega consigo uma dimensão de classe e está profundamente atrelado às estruturas sociais e econômicas mais amplas, consistindo, sobretudo, em poder e controle social.

Recorremos mais uma vez ao pensamento de Silva, acerca da "teoria crítica do currículo", quando afirma que

Com as teorias críticas aprendemos que o currículo é, definitivamente, um espaço de poder. $\mathrm{O}$ conhecimento corporificado no currículo carrega as marcas indeléveis das relações sociais de poder. $\mathrm{O}$ currículo é capitalista. $\mathrm{O}$ currículo reproduz - culturalmente - as estruturas sociais. O currículo tem um papel decisivo na reprodução da estrutura de classes da sociedade capitalista. O currículo é um aparelho ideológico do Estado capitalista. O currículo transmite a ideologia dominante. O currículo é, em suma, um território político.

As teorias críticas também nos ensinaram que é através da formação da consciência que o currículo contribui para reproduzir a estrutura da sociedade capitalista. $\mathrm{O}$ currículo atua ideologicamente para manter a crença de que a forma capitalista de organização da sociedade é boa e desejável. [...] A formação da consciência - dominante ou dominada - é determinada pela gramática social do currículo. (2005. p. 147/148)

Não poderíamos estar mais de acordo com Silva e talvez após o excerto acima nada mais precisasse ser escrito acerca do nosso posicionamento crítico de currículo, todavia é preciso enfatizar que deste ponto de vista marxista há uma clara conexão entre o modo de organização econômica e a forma como o currículo está estruturado. Neste sentido, as proposições de Apple (2001; 2006) são muito importantes em virtude de significativa colaboração para a abordagem do currículo com base nos conceitos de hegemonia e relações de poder, demonstrando que as

50 Silva (2005) identifica a existência de, ao menos, três correntes teóricas curriculares predominantes - tradicionais, críticas e pós-críticas -, que, em suma, divergem na questão do poder. As teorias tradicionais pretendem ser "teorias neutras", puramente científicas, enquanto as teorias críticas e pós-críticas, por outro lado, defendem a impossibilidade de uma neutralidade científica e asseveram que todas as teorias estão implicadas em relações de poder. Dessa forma, as teorias tradicionais estariam diretamente relacionadas às questões técnicas, de organização, não questionando os conhecimentos e os saberes dominantes, porquanto o conhecimento já está dado; e as teorias críticas e pós-críticas articulam questionamentos constantes não sobre o "como", mas sobre o "por quê": "Por que esse conhecimento e não outro?", "Por que privilegiar um determinado tipo de identidade ou subjetividade e não outro? As teorias críticas e pós-críticas de currículo estão preocupadas com as conexões entre saber, identidade e poder." (p. 16/17) 
instituições de ensino efetivamente operam uma distribuição de valores ideológicos e de conhecimento, bem como reproduzem o tipo de conhecimento (enquanto mercadoria) necessário para manter "os arranjos econômicos, políticos e culturais existentes", por ele denominado de “conhecimentos técnicos", e estruturam a tensão entre "a distribuição e a produção que parcialmente conta para que as escolas atuem de determinada maneira a fim de legitimar a distribuição de poder econômico e cultural" (p. 24). Este currículo, ou melhor, a ideologia orientadora deste documento não é recente. Sua construção, e transformações, são produtos de uma longa marcha histórica conquanto seu intuito seja apenas contextualizar a reflexão desenvolvida no capítulo seguinte.

A hegemonia, pensada por Gramsci, entra em cena como recurso teórico capaz de atestar a compreensão da sociedade como um campo de disputas, onde os dominantes estão permanentemente empenhados em garantir sua posição por meio do convencimento ideológico. Assim, "um elemento crítico para a ampliação da dominação ideológica de determinadas classes sobre outras é o controle do conhecimento que preserva e produz as instituições de determinada sociedade" (APPLE, 2006. p. 61), tal qual ocorre com a instituição escolar e que demanda uma análise cuidadosa dos currículos. Desde uma perspectiva filosófica, Gramsci nos brinda com sua filosofia da práxis que permite compreender o homem como um produto histórico-social e de essência produzida a partir das relações com o mundo objetivo e com outros homens, indicando um profundo distanciamento com qualquer perspectiva transcendental. Por conseguinte, somos levados a entender o real como a totalidade concreta, resultado das múltiplas determinações históricas advindas da própria luta humana de produção da sua existência. $\mathrm{O}$ real não é fruto das ideias dos homens - senão seria possível transformá-lo a partir das próprias ideias - tampouco provém de determinações externas, o que nos impossibilitaria de qualquer ação. Portanto, o real é uma construção histórica e social e, enquanto tal, pode ser transformado pela ação humana, segundo os interesses que dirigem estas ações.

O presente capítulo, por fim, buscou desenvolver uma abordagem da escola em sintonia com aquilo que apresentamos no primeiro capítulo, ou seja, um estudo do currículo de cunho ontológico e marxista. Entendemos que esta tarefa é fundamental para que possamos mergulhar nas questões propriamente ontológicas 
do currículo escolar de Geografia, desafio que será desenvolvido na próxima seção. Nossa jornada investigativa avança para abordar a realidade brasileira e, principalmente o currículo de Geografia escolar porquanto estão fincados os pilares empíricos que sustentam a pesquisa. Outrossim, entendemos ser relevante observar a inexorável relação entre a questão educacional e contexto socioeconômico e político mais amplo, justapondo o contexto histórico às questões mais estritamente curriculares, conduta que manteremos no próximo capítulo e que consolidam o currículo como produtos históricos. 
Geografia foi uma das disciplinas que respondeu diversas perguntas que eu tinha a respeito do desenvolvimento do planeta, e que me fez deixar de ser refém de um Deus.

Resposta de estudante entrevistado

\section{Geografia e currículo escolar no Brasil desde uma perspectiva ontológica}

A longa jornada investigativa desenvolvida chega a um momento decisivo após toda a fundamentação teórico-metodológica apresentada. Esta pesquisa foi iniciada de uma maneira e sofreu diversas transformações ao longo do seu curso, fato que também verificamos na realização da vida. A vida imita a arte e nos faz perceber que a condição de seres histórico-sociais implica também em nossa própria produção intelectual, produzida em metamorfose. Podemos considerar esta mais uma premissa ontológica que conduziu a caminhada até aqui, sugerindo que estamos presentes na arena da realidade material e social contemporânea na posição de "homem da sobrevivência", como nos ensina Vaneigem (1967), esmagados nos mecanismos do poder hierárquico, em meio ao caos de técnicas opressivas cuja "racionalização só espera a paciente programação pelos pensadores programados" (p. 10).

Nossa preocupação, por conseguinte, se concentrou não apenas nos "pensadores programados", mas também na "programação" e agora é chegado o momento de investigar como se dá esta relação através do currículo escolar de Geografia para o ensino médio. Como tentamos demonstrar ao longo de todo o texto, acreditamos, juntamente com diversos pensadores, que o real existe e esta existência pode ser apreendida intelectualmente. Destarte, se pode ser apreendida, pode ser também alterada pela ação cientificamente embasada, ideológica e conscientemente praticada pelo homem. É neste sentido que cabe pensarmos uma ontologia do currículo escolar, cujo objetivo consiste em resgatar a possibilidade de uma outra ação humana, ação que seja capaz de transformar a realidade a partir de uma outra relação com o espaço.

Nossa jornada não estaria completa sem que tratássemos da questão curricular da disciplina escolar Geografia para o ensino médio no Brasil. Essa tarefa, cabe reafirmar, não pretende exaurir a questão, tampouco afirmar uma alternativa a ser de imediato implementada. Nosso intuito é relativamente mais 
modesto e consiste em observar, de uma perspectiva ontológica, as transformações ocorridas no currículo escolar oficial de Geografia no Brasil até o final do século XX. Este procedimento, em nosso entender, pode colaborar para a reflexão crítica sobre o currículo escolar de Geografia e incentivar, de alguma forma, transformações radicais no processo de concepção curricular.

Ademais é preciso salientar que a fundamentação teórica desta seção decorre não apenas dos parâmetros trazidos até aqui, mas também da adoção de outros pensadores afinados com as premissas defendidas. Destarte, faz-se mister investigar as políticas oficiais curriculares em sua trajetória de constituição, especialmente a partir do século XIX quando houve a inclusão da disciplina escolar Geografia no rol de conteúdos. Num primeiro momento, portanto, faremos uma breve visita aos períodos colonial e imperial unicamente com o fito de entender os fundamentos políticos e históricos de construção curricular do Estado brasileiro até o século XIX, período em que mudanças significativas ganharam curso em virtude das transformações do contexto sociopolítico nacional e internacional. A partir de então dedicaremos mais atenção ao período republicano brasileiro desde uma perspectiva crítico-histórico, destacadamente aos principais movimentos de reorientação curricular que conduziram à reformulação curricular de Geografia do ensino médio nos anos finais da década de 1990. É de extrema importância ressaltar que o estudo a ser desenvolvido neste capítulo procura relacionar o currículo escolar com a questão ontológica, ou seja, estaremos mais uma vez imbuídos da ideia de tecer laços entre gnosiologia e ontologia com o objetivo de construir uma perspectiva histórica que culmina com a reelaboração curricular promovida pelo governo neoliberal brasileiro liderado por Fernando Henrique Cardoso.

Nosso foco é o currículo de Geografia para o ensino médio, especialmente a partir de sua introdução nos programas escolares a partir do século XIX, portanto não temos a menor intenção de desenvolver uma prolongada discussão sobre a história curricular brasileira. Deste modo, reafirmamos ser imprescindível pensar o currículo como um produto histórico e cuja trajetória precisa ser recuperada para que possamos compreender o momento contemporâneo, todavia, não é demais frisar, dedicaremos maior ênfase nas questões propriamente curriculares da disciplina escolar Geografia. 
Outrossim, também precisamos fazer referência ao desenvolvimento da ciência Geográfica, que passou por diferentes momentos ao longo de sua trajetória e manteve fortes laços com os espaços escolares, influenciando a construção dos diferentes currículos disciplinares ao longo das mudanças ocorridas no sistema educacional brasileiro. De acordo com esta perspectiva, a estratégia operacional adotada é justamente iniciar a discussão do presente capítulo com as questões relacionadas às transformações do pensamento geográfico até o período de emergência da chamada Geografia moderna. A partir de então daremos início à temática mais propriamente curricular brasileira desde o período colonial, quando poderemos observar com bastante clareza o currículo como produto e reflexo da sociedade e projeto burguês de país. As temáticas curriculares geográficas serão relacionadas com o desenvolvimento da ciência geográfica, permitindo uma compreensão mais adequada dos objetivos propostos. Este percurso nos conduzirá até a segunda metade do século XX, período de grandes transformações sociais, políticas, econômicas e científicas, não apenas no Brasil, mas no mundo, impelindo o desenvolvimento de uma arguição conjunta entre a reorganização do sistema escolar nacional, as mudanças cientificas geográficas e contexto políticoeconômico brasileiro. A última etapa de nossa jornada investigativa chegará na década de 1990 com o principal objetivo de elucidar as orientações curriculares de Geografia para o ensino o ensino médio, tarefa que conduziremos de modo semelhante ao período anterior, ou seja, articulando as questões curriculares com o contexto político-econômico mais amplo, quando o neoliberalismo invade documentos de reordenação curricular.

Esta opção argumentativa nos levou inicialmente às obras concernentes ao desenvolvimento do pensamento geográfico, com destaque para Moraes (2005) e Gomes (2006). Também nos servem de referência os trabalhos de Zotti (2004), Nagle (1976), Freitag (1980) e Piletti (1987) para refletir o processo de constituição do currículo escolar brasileiro. Cumpre ressaltar que nosso foco investigativo reside no ensino médio, como já assinalado anteriormente, o que nos faz abordar a sua organização institucional no sistema de ensino brasileiro. Rocha (1996) e Vlach (edições Kindle, sem data) descortinam a questão curricular em Geografia ao discutirem como o desenvolvimento do pensamento geográfico repercutiu na Geografia escolar e nas políticas oficiais curriculares implementadas. À esta 
fundamentação será coadunada reflexões de pensadores já discutidos, mas ainda de vital importância como Marx (1996) e Lukács (2013) por nos fornecerem subsídios teóricos imprescindíveis para desvendarmos os interstícios do modo de produção capitalista em sua dimensão ontológica, bem como por permitirem uma compreensão mais lúcida da categoria trabalho como mediação fundamental da relação sociedade-natureza, tema a ser explorado mais à frente. Isto posto, seguimos nosso caminho.

\subsection{A Geografia clássica e Geografia moderna}

A marcha de compreensão curricular da disciplina Geografia nos obriga a abordar, ainda que não de forma aprofundada, o cenário científico mais amplo que desembocou na inclusão da Geografia no currículo escolar. De início, cumpre afirmar que esta argumentação precisa ser realizada a partir das considerações já assinaladas acerca do desenvolvimento científico ocidental no século XIX, quando as bases filosóficas do positivismo serviram de base para o pensamento geográfico tradicional.

É preciso assinalar que anteriormente a esse período moderno, ainda na Antiguidade Clássica, o rótulo "Geografia" já era utilizado para uma série de conteúdos. Os gregos cunharam o termo Geografia $($ Geo $=$ Terra; grafia $=$ descrição) para se referir ao ato de descrição da Terra, que, por sua vez, demanda a produção de mapas para a localização dos objetos descritos, os territórios. Dentre diversos exemplos possíveis desse ato, podemos citar o caso da Grécia, em que, por um lado, Ptolomeu concentrou seus esforços na medição do espaço e na discussão da forma da Terra; enquanto, por outro lado, Estrabão se voltou a descrição dos lugares.

Ptolomeu foi um dos responsáveis pela arte da cartografia, dominando conhecimento matemáticos e astronômicos, não à toa foi geógrafo, matemático e astrônomo. É dessa raiz que floresce a chamada "Geografia matemática", estritamente vinculada aos aspectos geométricos relacionados à astronomia, cosmografia e a cartografia em detrimento das questões físicas e humanas presentes sobre a superfície. Prado Jr. (2012) acerca do trabalho desenvolvido pelo grego escreveu que 
A posição de Ptolomeu diante do problema geográfico coincidirá perfeitamente com as necessidades da época em que renascem os estudos de geografia. Inaugurava-se a grande navegação oceânica, a exploração dos mares, de rotas e terras desconhecidas; havia que preocupar-se, acima de tudo, com os dados e conhecimentos necessários à realização daquelas tarefas. A cosmografia se tornará o capítulo principal da geografia, e com ela a cartografia em que se concretiza. (p. 339)

Estrabão, por seu turno, foi um viajante, historiador e geógrafo, que produziu uma Geografia marcadamente descritiva. Em suas viagens, todos os fatos observados (territórios e sociedades) foram transformados em relatórios minuciosos. Indiscutivelmente a "Geografia descritiva" legou profundas influências na Geografia escolar, como veremos melhor logo mais à frente.

Destarte, o termo que melhor designa este período é o de "dispersão", ou seja, os estudos que se consideravam "geográficos" não apresentavam um conteúdo comum e assim permaneceu até o final do século XVIII. Portanto, até o início do século XIX não há um conhecimento geográfico organizado, sistematizado, com um padrão temático definido. Assim, a "Geografia" consistia em relatos de viagens, compêndios de curiosidades sobre diferentes locais, relatórios estatísticos de órgãos administrativos, catálogos sistemáticos sobre continentes e países etc., significando que "trata-se de todo um período de dispersão do conhecimento geográfico, onde é impossível falar dessa disciplina como um todo sistematizado e particularizado" (MORAES, 2005. p. 50).

Portanto, nesse período se estruturou um conjunto de concepções teóricometodológicas que constituíram a chamada Geografia Clássica, a partir especialmente das contribuições de Ptolomeu e Estrabão. Mais uma vez é Prado Jr. (idem) quem nos ajuda a explicar aquele período ao escrever que

É com estes dois modelos, o de Ptolomeu e o de Estrabão, que se vai constituir a geografia clássica, cuja história se prolongará até o século XIX. Respectivamente de um e de outro se originarão as duas grandes partes em que tradicionalmente se dividirá a matéria: geografia matemática e política. A primeira abrange a parte geral, onde ao lado da astronomia, cosmografia e cartografia se colocam as considerações gerais sobre a Terra e sua configuração. Na outra se reúne a descrição dos diferentes países e povos. (p. 341)

A adequada compreensão da constituição da Geografia clássica exige que façamos referência ao papel dos geógrafos árabes por permitirem ao ocidente terem 
contato com as obras dos autores gregos. Rocha (1996) afirma que o interesse árabe pelos conhecimentos geográficos era muito grande graças ao expansionismo islâmico ocorrido por volta do século XII, numa campanha que culminou em expressiva extensão territorial, desde o Oriente Médio até o norte africano. Os estudiosos árabes recuperaram a produção de Ptolomeu, tornada fundamento da Astronomia e da Geografia matemática durante toda a Idade Média. A partir de então, a produção geográfica grega foi traduzida e consistiram pedra angular para os estudos geográficos que se desenvolveram na Europa, especialmente a partir do século XIV, quando o continente europeu passou por profundas transformações de ordem social, política, econômica e territorial com a decadência do feudalismo e assunção do capitalismo.

É já bastante sabido que o mercantilismo praticado inicialmente no século $\mathrm{XV}$ foi o grande responsável pela expansão europeia nos séculos seguintes, promovendo a multiplicação de informações obtidas nos diferentes territórios e ampliando o acervo geográfico. Data deste período também o já assinalado Renascimento cultural, cuja importância para a ciência Geográfica reside principalmente na retomada dos conhecimentos escritos da Antiguidade Clássica, com destaque às obras de Ptolomeu e Estrabão para a constituição da Geografia (ROCHA, 1996).

Gomes (1996) é bastante preciso acerca das contribuições destes dois pensadores ao escrever que

\begin{abstract}
Estes dois autores fundaram então duas escolas de geografia, que conviveram lado a lado até a revolução científica. Certos geógrafos procuraram reunis ao mesmo tempo os princípios gerais cosmográficos e as descrições regionais corográficas, integrando assim, em uma mesma obra, essas duas abordagens até aí distintas. É então possível afirmar que existia já nessas tentativas de integração uma maneira de conceber a geografia como uma relação entre a organização geral do mundo e sua imagem, de um lado, e a fisionomia particular de algumas de suas partes, de outro. (p. 130)
\end{abstract}

Como veremos melhor mais adiante, estes princípios científicos se manifestaram de forma bastante evidente nas aulas de Geografia, tanto no currículo, como nas práticas pedagógicas. Neste sentido, é lícito afirmarmos que a Geografia clássica, abordando questões matemáticas e astronômicas, bem como apresentando longos relatos de diferentes locais do planeta esteve, e a bem da verdade, ainda está 
manifestada nos currículos escolares de Geografia ao longo das diferentes reformas e reorganizações implementadas pelo Estado. Com o intuito de melhor organizar nossa explanação o próximo passo consiste na discussão em torno da sistematização do conhecimento geográfico, quando nos debruçaremos sobre a trajetória curricular oficial do país. Destarte, será possível observarmos adequadamente como a Geografia clássica e posteriormente a Geografia moderna influenciaram a Geografia escolar.

A continuidade de nossa argumentação chega aos primeiros anos modernos, marcados pela grande profusão de dados e informações sobre diferentes locais e sociedades. No início do século XIX diversas disciplinas definiram seus objetos e organizaram seu estatuto científico e a Geografia, em particular, permanecia órfã de um padrão científico organizado e não possuía um corpo interpretativo próprio que lhe conferisse uma identidade própria. Destarte, emerge com grande força, no interior da Geografia, a necessidade de definir o seu método científico e a partir da revolução científica do século XVIII a dimensão metafísica é profundamente questionada em nome da necessidade de legitimação epistemológica para validação dos métodos. Por conseguinte, Gomes (1996) afirma que a Geografia colocou "sob sua responsabilidade a interpretação da dinâmica da natureza e de suas relações possíveis com a marcha da história" (p. 150).

Não resta dúvida que a Geografia se dedicou a temática da relação homemnatureza em um período de grande expansão das relações capitalistas de produção. Destarte, já havia um vasto acervo de informações sobre os diferentes locais do planeta, bem como sobre a extensão da superfície terrestre, condição que permitiu a transição para o modo de produção capitalista através da articulação de suas relações em escala planetária, como também forneceu registros para a criação de um grande repositório mundial. É preciso salientar também a sofisticação das técnicas cartográficas, um instrumental fundamental para a representação dos fenômenos observados e da localização dos territórios (MORAES, 2005), consistindo num requisito de grande relevância para a navegação atingir locais distantes através de rotas seguras e assegurar a expansão do comércio.

Como podemos perceber os conhecimentos geográficos vão sendo sistematizados tendo como pano de fundo o avanço das relações capitalistas, bem como se desdobra sobre um movimento de rearranjo da ciência na transição do 
Feudalismo para o Capitalismo. Com relação a estes múltiplos rearranjos é interessante trazermos as considerações de Moraes (idem) que bem resumem esse cenário de transformações:

A Terra estava toda conhecida. A Europa articulava um espaço
de relações econômicas mundializado, o desenvolvimento do
comércio punha em contato lugares mais distantes. O
colonizador europeu detinha informações dos pontos mais
variados da superfície terrestre. As representações do globo
estavam desenvolvidas e difundidas pelo uso cada vez maior dos
mapas, que se multiplicavam. A fé na razão humana, imposta
pela Filosofia, abria a possibilidade de uma explicação racional
para qualquer fenômeno da realidade. As bases da ciência
moderna já estavam assentadas. As ciências naturais haviam
constituído um cabedal de conhecimentos e teorias, do qual a
Geografia lançaria mão, para formular seu método. E,
principalmente, os temas geográficos estavam legitimados como
questões relevantes, sobre os quais cabia dirigir indagações
científicas. (p. 56)

Com todas estas condições dispostas a Geografia moderna estava apta a compor o rol das ciências modernas, tendo como base filosófica os fundamentos positivistas. O positivismo circunscreve todo o trabalho científico ao mundo das aparências fenomênicas, ou seja, os estudos científicos devem se limitar aos aspectos visíveis do real, mensuráveis, palpáveis. Portanto, ao cientista cabe observar os fenômenos que se apresentam diretamente ao seu olhar, conduta que restringe a pesquisa à indução. Não obstante, é vedada a consideração a qualquer outro método científico, ou seja, a análise dos domínios da natureza ou dos domínios da sociedade deve ser realizada a partir do único método possível: aquele empregado pelas ciências da natureza.

A fundamentação positivista traz a reboque o aspecto de "ciência de síntese", isto é, uma pretensa capacidade de conseguir trabalhar com o conjunto de fenômenos que compõem o real. Não obstante, a Geografia tem a pretensão de abordar elementos das demais ciências, passando da descrição à explicação em uma análise dotada de princípios e métodos próprios dos fenômenos físicos, biológicos e humanos. Acerca desta conduta, que permitiu a libertação da Geografia de sua matriz descritiva, Moraes (Idem) assevera que

Estes princípios, formulados a partir da pesquisa de campo, seriam conhecimentos definitivos sobre o universo da análise, que o geógrafo não poderia deixar de lado em seus estudos. 
Atuam assim como regras de procedimento, e por esta razão forneceram um elemento de unidade para a Geografia. A saber, são eles, para ficar apenas nos mais expressivos: $\mathrm{O}$ "principio da unidade terrestre" - a Terra é um todo, que só pode ser compreendido numa visão de conjunto; o "principio da individualidade" - cada lugar tem uma feição, que lhe é própria e que não se reproduz de modo igual em outro lugar; o "principio da atividade" - tudo na natureza está em constante dinamismo; o "principio da conexão" - todos os elementos da superfície terrestre e todos os lugares se inter-relacionam; o "principio da comparação" - a diversidade dos lugares só pode ser apreendida pela contraposição das individualidades; o "principio da extensão" - todo fenômeno manifesta-se numa porção variável do planeta; o "principio da localização" - a manifestação de todo fenômeno é passível de ser delimitada. Estes princípios atuaram como um receituário de pesquisa, definindo regras gerais, no trato com o objeto, que, não podiam ser negligenciadas. De certo modo, definiam os traços que faziam um estudo aceito como de Geografia. Deve-se ressaltar que a idéia de princípio é bastante cara ao pensamento positivista, o que reafirma o juízo de que a Geografia deve sua unidade a um fundamento comum com esta corrente filosófica. (p. 42/43)

As orientações da Geografia direcionaram os estudos para a disponibilização de explicações, identificação e distribuição dos fenômenos observados, restando retrógado a mera descrição do fenômeno em tela, ou seja, a Geografia se torna uma ciência moderna ao abandonar a simples descrição pela procura de estabelecimento da relação entre causa e efeito através da explicação. A partir daquele período a Geografia estabeleceu como meta a descrição explicativa da Terra e dos fenômenos manifestados passiveis de serem observados (ROCHA, 1996), evidenciando a grande contribuição de alguns estudiosos alemães para essa transformação, como Humboldt, Ritter e Kant.

Humboldt é considerado por diversos estudiosos o primeiro a organizar as novas regras do pensamento geográfico moderno. Assim, se as viagens do século XVIII valorizavam a observação direta e a descrição minuciosa, Humboldt retomou este procedimento e coadunou o exercício de comparações e raciocínios gerais e evolutivos, descrevendo cada fenômeno na relação com os outros e acentuando sua interação recíproca (GOMES, 1996). Do mesmo modo, Humboldt também observava separadamente as sociedades locais, que, em seguida, eram recolocadas em conexão com as outras a fim de resgatar uma cadeia explicativa. Neste sentido, a despeito das narrativas de viagens e das descrições detalhadas, Humboldt soube "graças à sua grande cultura, reconduzir essas tradições a um novo modelo 
científico e atualizá-las levando em conta as principais descobertas da época" (Idem, p. 151).

As principais obras de Humboldt, "Quadros da natureza" e "Cosmos", indicam como o autor entendia a Geografia como a parte terrestre da ciência do cosmos, isto é, "como uma espécie de síntese de todos os conhecimentos relativos à Terra" (MORAES, 2005). Por conseguinte, a Geografia consiste, segundo sua concepção, numa disciplina eminentemente sintética, atenta com a interdependência entre os elementos físicos e procurando através dessas conexões a causalidade típica da natureza. Humboldt mesmo com toda a sua formação bastante eclética (botânica, astronomia, mineralogia, física e geologia) não acreditava numa justaposição de conhecimentos, mas dedicou-se a desenvolver um quadro de síntese que integrava o mundo dos fenômenos e o das forças físicas em sua conexão e influência mútua.

Ritter é considerado, ao lado de Humboldt, como um dos fundadores da Geografia moderna e científica, estabelecendo as bases de um saber organizado e metodologicamente rigoroso. Assim, é possível perceber que o principal foco de Ritter é metodológico porquanto a Geografia existente era apenas um conjunto desordenado de dados coletados sem nenhuma preocupação científica (GOMES, 1996). Segundo esse mesmo autor, Ritter entendeu a Geografia enquanto domínio responsável pelo estudo da Terra em seu conjunto e das manifestações fenomenais, sendo, portanto, capaz de estabelecer a relação lógica entre o todo e suas partes. Neste sentido, a concepção de uma "organização geral, no que diz respeito à distribuição dos fenômenos terrestres, deve substituir o olhar simples, que vê apenas a desordem aparente, a imagem confusa da diversidade" (Idem, p. 165). Neste sentido, a proposta de Ritter é antropocêntrica (homem é sujeito da natureza), regional (estudos das individualidades locais) e valorizando a relação homemnatureza.

Kant, por fim, já foi bastante discutido no primeiro capítulo, o que nos desobriga de uma abordagem mais detalhada, todavia algumas considerações ainda são necessárias para adensar a compreensão das transformações científicas que, de alguma forma, impactaram na organização curricular da disciplina Geografia por longo período. Como já assinalado, para Kant espaço e tempo são intuições puras, a priori, contudo "Geografia não pode ser simplesmente definida pela intuição pura 
do espaço", fato que impele a busca pelo estabelecimento de "relações espaciais entre diversos fenômenos apreendidos através de experiências, as quais são guiadas por conceitos logicamente arranjados no pensamento" (Idem. p. 141). São estas premissas que permitiram a Kant sistematizar as bases metodológicas da Geografia na Alemanha.

Para Kant, a antropologia se ocupava do homem e a Geografia física da natureza, ambas constituindo, por um lado, a primeira parte do conhecimento do mundo, pressupostos básicos para a compreensão das percepções do mundo pelo homem e fornecia, por outro lado, um sistema para o estudo da natureza (SODRÉ, 1976). Coerente com esta perspectiva, Kant afirmava que a experiência humana colhida indiretamente se divide em duas espécies: uma narrativa (História) e outra descritiva (Geografia). Assim,

\begin{abstract}
A História era o registro dos acontecimentos que se sucediam no tempo; a Geografia era o relatório de fenômenos que se sucediam no espaço. Juntas, constituíam o conhecimento empírico. Kant opinava que a Geografia antecedera a História, sendo a estrutura desta, uma vez que os fatos ocorriam sempre em determinado lugar. (p. 28)
\end{abstract}

As obras destes dois autores são consideradas a base da Geografia Moderna e desempenharam papel institucional muito importante na formação das cátedras dessa disciplina, proporcionando uma identidade acadêmica. Outro fator de grande relevância para o surgimento das cátedras nas instituições universitárias foi a necessidade de formação de professores para o trabalho nas instituições escolares lecionando aulas de Geografia, em níveis primário e secundário. Desta forma, segundo alguns estudiosos da Geografia escolar e do pensamento geográfico, é possível afirmar que a institucionalização e legitimação científicas da Geografia é tributária do papel exercido pela disciplina escolar. A esse respeito, Vesentini (2012) afirma que

Malgrado a maior parte das obras que analisam a "história da geografia", persistirem em ignorar o ensino, pensamos que foi pelo seu papel social no sistema escolar que a Geografia Moderna teve sua função de pesquisa legitimada. E não o inverso, como equivocadamente ainda trazem muitos manuais, ou seja, que o ensino seria um "complemento" decorrente da produção "científica", da pesquisa empírica. (p. 34) 
A partir desta breve exposição do desenvolvimento do pensamento geográfico, pensamos ter criado subsídios teóricos suficientes para a devida interpretação da constituição dos currículos escolares de Geografia, processo que teve início no Brasil apenas em meados do século XIX. A próxima sessão deste capítulo marca o começo da discussão propriamente curricular brasileira e, como já salientado anteriormente, acreditamos ser inevitável efetivar a recuperação deste processo porquanto o currículo é um produto social e histórico bastante particular e serve de expressão concreta dos ideais que organizaram primeiramente o projeto de colônia e posteriormente o projeto de país, bem como fornecem valiosos indícios da questão ontológica que perseguimos.

\subsection{Os jesuítas e o Marquês de Pombal pensando o currículo escolar}

A história da educação escolar no país tem início ainda no período colonial, mais precisamente no século XVI, quando os jesuítas se responsabilizaram pelo ensino. A sociedade mercantilista adotou valores profundamente arraigados à religião católica, como a catequese e a educação institucionalizada, atribuições que ficaram a cargo destes religiosos ${ }^{51}$. Não é nenhum mistério que colonizar também significou a imposição de uma ideologia dominante, ou seja, não bastava apenas colonizar as terras, mas também era preciso colonizar as consciências e coube aos jesuítas manter e difundir a visão do colonizador através da fusão entre colonização, educação e catequese.

Nesse sentido o exercício da dominação estava sustentado pela garantia da economia agrária, latifundiária e escravista, fundamentos de interesse da burguesia mercantil, que, por sua vez, colocava a educação escolarizada sob sua tutela. Assim, a educação praticada era conveniente e interessava às camadas dirigentes, servindo à articulação entre os interesses metropolitanos e as atividades coloniais. Esta conduta realizou-se atribuindo máxima atenção à criança indígena com o fito de

\footnotetext{
${ }^{51}$ Freyre (2005) em estudo célebre aborda o papel da escravidão e do catolicismo na construção da identidade nacional ressaltou o papel dos jesuítas na condução da educação brasileira. Ele escreveu que "os colégios dos jesuítas nos primeiros dois séculos, depois os seminários e colégios de padre, foram os grandes focos de irradiação de cultura no Brasil colonial. Aqueles estenderam tentáculos até os matos e sertões" (p. 501).
} 
dissolver, o mais breve possível, tudo o que fosse nativo em conflito sério com a teologia e com a moral cristã. Freyre (2005) nos ensina que

O culumim [criança], o padre ia arrancá-lo verde à vida selvagem: com dentes apenas de leite para morder a mão intrusa do civilizador; ainda indefinido na moral e vago nas tendências. Foi, pode-se dizer, o eixo da atividade missionária: dele o jesuita fez o homem artificial que quis. (p. 218)

A passagem acima ressalta um papel fundamental exercido pela atividade educacional voltada à construção de um "homem artificial", ou seja, um homem distanciado de sua natureza, extraído de seu próprio ser para formar um outro sujeito. A ação jesuítica reforça toda a discussão desenvolvida ao longo deste estudo ao implementar na Colônia um movimento de reconstrução das subjetividades que, segundo nosso entendimento, nunca foi interrompido de "artificializar" os sujeitos em sua essência e, por conseguinte, de redirecionar a relação do homem com o espaço, promovendo uma relação estranhada. É evidente que aqui ainda não podemos verificar com maior minúcia o papel do currículo de Geografia, mas, por outro lado, já se torna indiscutível que um dos propósitos da educação foi “quebrar" a cultura nativa pela ação na consciência dos "culumins", ou melhor, "longe dos padres quererem a destruição da raça indígena: queriam era vê-la aos pés do Senhor, domesticada para Jesus" (Ibidem).

A educação jesuítica, comandada pelo Padre Manuel da Nóbrega, pressupunha como matriz curricular básica o ensino da doutrina cristã, dos "bons costumes (portugueses)" e das primeiras letras. Não resta dúvida que esta composição curricular foi pensada com o fito de atender as necessidades mais imediatas de um colonizador europeu e cristão. Assim, a doutrina cristã cumpria um papel econômico importante ao docilizar o índio e torná-lo mão de obra. As primeiras letras portuguesas era uma necessidade colonial de primeira ordem e foi bastante estimulada pela catequese ${ }^{52}$. Ao relacionarmos as necessidades do colonizador com as demandas econômicas do período mercantilista se torna

\footnotetext{
${ }^{52}$ Cumpre ressaltar que, segundo ZOTTI (2004), apenas após estarem iniciados no catolicismo e com algum domínio sobre a língua portuguesa falada é que os índios iniciavam a "escola de ler e aprender". O prosseguimento dos estudos apresentava uma rígida divisão: aos que se destacavam o estudo da gramática latina e aos demais o ensino profissional, agrícola ou manufatureiro (Ibidem). Essas etapas estruturadas de modo dual correspondiam ao atual ensino médio, em que o estudo da gramática objetivava a preparação para as humanidades superiores, para a filosofia e a teologia, culminando com uma viagem de estudos na Europa.
} 
evidente a opção pela garantia do controle territorial, relegando ao segundo plano o preparo técnico da mão de obra para as atividades manufatureiras e mercantis. Neste contexto, a educação jesuítica buscou se apoderar do ensino clássico para pôlo a serviço da Igreja.

Ponce (2001) afirma em sua obra que a inculcação da cultura intelectual desenvolvida pelos jesuítas visava justamente evitar a emancipação intelectual, objetivo que restava evidenciado com a exclusão dos conhecimentos históricos e científicos, a menos que a história fosse deturpada de tal forma que ficasse irreconhecível ou "que a ciência fosse tão superficial, que mais parecesse uma brincadeira de salão. A educação jesuíta só usava os recursos pedagógicos como instrumento de dominação" (p. 120). Esta concepção educacional, podemos dizer, católica da Companhia de Jesus tinha o claro objetivo de fortalecer o poder papal e defender a Igreja contra qualquer ameaça, difundindo suas ideias e símbolos com o verniz da cultura para nobres e burgueses abonados em detrimento das classes populares.

A morte de Nóbrega em 1570 significou uma reorientação da educação na colônia, quando se verificou um estímulo à construção de colégios nos principais centros urbanos do litoral que oferecessem o ensino das primeiras letras, ensino secundário e o superior. A partir de então a educação passa a ser artigo exclusivo das elites, ou seja, passa a servir como instrumento de formação das elites burguesas com o objetivo de prepará-las para o exercício da hegemonia cultural e política da Colônia, segundo os interesses de Portugal. Cunha (2007) afirma que os jesuítas cumpriam uma tripla função com sua prática educativa: "de um lado, formar padres para a atividade missionária; de outro, formar quadros para o aparelho repressivo (oficiais da Justiça, da Fazenda e da Administração); de outro, ainda, ilustrar as classes dominantes no local” (Edições Kindle, sem paginação). Por conseguinte, ainda segundo Cunha (idem)

\footnotetext{
A integração dessas funções assim variadas ficava garantida pela presença, no currículo desses colégios, das ideologias e das práticas letradas comuns à cultura das classes dominantes, às diversas especialidades da burocracia estatal e à organização da própria ordem religiosa que as ensinava. (Ibidem)
}

A formação dessa classe dominante colonial é desenvolvida a partir de uma rígida maneira de pensar e interpretar a realidade, princípios da educação 
organizados e orientados pelo Ratio Studiorum ${ }^{53}$. Esse documento consistiu num plano de estudos, elaborado por 59 anos e publicado em 1599, em que os jesuítas definiram uma coleção de regras e prescrições práticas e detalhadas, ou seja, "um currículo que ia muito além das disciplinas ou conteúdos escolares" (ZOTTI, 2004. p. 21), buscando formar o perfeito homem cristão. Por conseguinte, é bom que se afirme, não era objetivo da escola "dar a consciência de cidadão de tal ou tal império ou de representante desta ou daquela raça predestinadas" (LEONEL FRANCA, 1952. p. 20). Destarte, acreditamos estar diante de um documento oficial orientador da política curricular nacional, que simboliza com maestria aquele fenômeno “disciplinar” explicitado por Foucault (2004). Vejamos como Leonel Franca (1952) explica o trabalho do professor:

No seu trabalho, o professor é eficientemente ajudado pelos alunos. A aula não se apresenta como uma multidão inorgânica de unidades desarticuladas a ouvir passivamente o mestre que discorria do alto da sua cátedra. Há em primeiro lugar os decuriões e censores. Estes auxiliam na conservação da ordem e da disciplina, aqueles corrigem os deveres e tomam as lições. Acima de uns e de outros, toda uma magistratura bem hierarquizada: senadores, tribunos, cônsules, imperator. Toda a aula divide-se em dois campos com as suas organizações político-militares paralelas. No preenchimento destes cargos, nenhuma proteção ou intriga. Só o mérito apurado em trabalhos escolares rigorosamente examinados, compositiones pro imperio, decide, cada mês ou cada dois meses, da nova promulgação de postos. Dentro de cada campo, os desafios freqüentes permitem a promulgação gradual dos mais valentes. Desenvolvia-se assim nesta magistratura juvenil o senso da responsabilidade, a solidariedade de corpo, a consciência da autoridade e a disciplina da obediência, o respeito da legalidade e ao mesmo tempo plasma-se a aula nos moldes de um organismo social bem estruturado. (p. 28)

Resta bastante claro a estratégia disciplinar adotada com vistas a reproduzir em sala de aula o comportamento esperado na sociedade, ou seja, a obediência exemplar, a norma disciplinadora, os cargos definidos, o respeito inquestionável. Foucault (idem) explica esse processo apontando que esses "métodos permitem o controle minucioso das operações do corpo, que realizam a sujeição constante de suas forças e lhes impõem uma relação de docilidade-utilidade, são os que podemos chamar de 'disciplinas"” (p. 118). O Ratio Studiorum é considerado uma obra prima 53 Para maior conhecimento, este documento está disponível em:
https://www.histedbr.fe.unicamp.br/acervo/fontes/4782 Acessado em 25/08/2021. 
de organização para inibir o mínimo estímulo nos estudantes de uma independência pessoal e alcançar, por outro lado, colaboradores ativos e zelosos da administração pública e dos mais variados setores da Colônia. A educação, consequentemente, advém de uma concepção de mundo pronto, de funcionamento perfeito, sendo sua atribuição preparar o homem para vivê-lo, ou seja, a educação era privilégio dos nobres e dos burgueses, responsáveis pela condução da sociedade. Esta situação deixa bastante claro que a proposta educativa jesuítica estava voltada a atender os interesses de uma parcela exclusiva da população, posicionamento que, numa sociedade baseada na escravatura, significava atribuir prioridade à educação secundária e superior. Cumpre afirmar que havia no Brasil quatro níveis de ensino, sucessivos e propedêuticos: o curso elementar (escola de ler, escrever e contar, mais a doutrina católica); o curso de humanidades (nível secundário); o curso de artes (também chamado de ciências naturais ou filosofia) e o curso de teologia (nível superior) (ZOTTI, 2004).

Em meio a esse contexto, é interessante observarmos com maior detalhe o que viria a ser o futuro ensino médio. A observação mais atenta do curso secundário (atual ensino médio), ou humanidades, revela este ser o mais difundido na colônia, pilar da estrutura educacional desenvolvida pela Companhia de Jesus. Os cinco anos de curso consistiam num caráter literário e humanista, cujo objetivo residia no preparo do aluno para

A arte acabada da composição, oral e escrita. O aluno deve desenvolver todas as suas faculdades, postas em exercício pelo homem que se exprime e adquirir a arte de vazar esta manifestação de si mesmo nos moldes de uma expressão perfeita. As classes de gramática asseguram-lhe uma expressão clara e exata, a de humanidades, uma expressão rica e elegante, a de retórica mestria perfeitamente na expressão poderosa $\mathrm{e}$ convincente ad perfectam eloquentiam informat [do latim: a eloquência perfeita deles. Tradução livre]. (LEONEL FRANCA, 1952. p. 23 grifos do autor).

Mais a frente, o mesmo autor assegura que "no plano do Ratio, enquanto os cursos universitários visam mais diferentemente a formação profissional, o secundário tem uma finalidade acentuadamente humanista" (p. 38), condição que favorecia às políticas colônias porquanto numa sociedade que muitos produziam, os poucos privilegiados dedicavam-se apenas às atividades intelectuais. Zotti (2004) assinala que esta situação estimulou uma visão pejorativa do trabalho, 
associado ao escravo, e que, portanto, não trabalhar era sinônimo de status, de posição social privilegiada. Não obstante, o curso secundário descrito no Ratio não intentava transformar os adolescentes em enciclopédias ambulantes, mas o currículo de caráter profundamente humanista buscava formar o homem, torná-lo "mais homem", ou melhor, "homens educados, afáveis, lhanos, acessíveis e tratáveis” (LEONEL FRANCA, 1952. p. 39) através do recurso da linguagem, considerada o instrumento natural da formação humana. O mesmo sacerdote jesuíta escreve que

Só pela palavra pode o autor atingir o espírito do aluno; só pela palavra pode o educador manifestar o próprio espírito. Uma faculdade revela-se na ação, que lhe é própria e que, por isso, se pode chamar a sua expressão. A linguagem é a expressão do espírito, e, portanto, com a prova de sua existência, a medida do seu desenvolvimento. Mais. Quem se exprime, exercita a sua atividade mental, imagina, pensa, julga, raciocina, concatena idéias. Através da expressão pode, portanto, o professor, exercitar a atividade interior do estudante e medir-lhe e orientarlhe o progresso. (Ibidem)

Zotti (2004) afirma que a organização da educação jesuítica, mais propriamente do currículo humanista, tinha sobretudo objetivo religioso, nos moldes do catolicismo, acarretando a adoção de um conteúdo literário e de metodologias que visavam afastar os intelectuais das demais orientações religiosas, como também da nascente ciência moderna. Portanto, em suma, era tarefa básica manter a Colônia sob o monopólio intelectual da metrópole e, de acordo com Freyre, "da mesma forma como a monocultura econômica destruiu fisicamente o resto da paisagem, assim também na escola jesuítica a monocultura intelectual e espiritual destruiu em torno do indivíduo a paisagem intelectual" (apud ZOTTI, 2004. p. 24).

O panorama educacional brasileiro permaneceu praticamente o mesmo enquanto esteve sob responsabilidade da Companhia de Jesus, período que durou até 1759 quando são expulsos de Portugal e, consequentemente, do Brasil. A brusca interrupção da educação jesuítica é realizada pelo Marquês de Pombal, então ministro de D. José I. A partir de então o Estado se responsabiliza pela primeira vez pela educação e coloca como princípio norteador a substituição da escola da fé pela escola útil aos interesses do Estado. De maneira bastante simplificada podemos afirmar que o fim do período jesuítico provoca a completa extinção daquele sistema 
educacional sem que seja implementado um outro modelo em substituição, quando muito houve a definição de normas gerais e a instituição de algumas aulas régias. Vejamos melhor como se deu o período pombalino.

As reformas implementadas pelo Marquês de Pombal alcançaram diferentes setores da monarquia portuguesa com o fito de promoverem recuperação econômica através de algumas mudanças, como a modernização do ensino. É exatamente nesta dimensão que concentraremos nosso olhar, com especial destaque às transformações ocorridas no sistema educacional brasileiro. Por conseguinte, cientes de nosso objetivo, não buscamos problematizar as reformas pombalinas ou investigar suas consequências imediatas ou ainda mergulhar no movimento iluminista português, mas delinear o processo de (re)construção escolar da Colônia que vai desembocar na organização curricular implementadas pelo Império no século XIX. Este período é de grande valia, pois registra a inclusão da Geografia no currículo escolar e assenta algumas premissas político-ideológicas subsistentes ao longo da República e que ainda se fazem perceber.

Pois bem, as reformas pombalinas no campo educacional refletem o pensamento iluminista português, que protagonizou uma remodelação dos métodos educacionais existentes pela introdução da filosofia moderna e das ciências da natureza. Foucault já sinalizara estas mudanças e, particularmente no caso lusitano, suas manifestações se traduziram em um programa político de governo, que enfrentou resistências oriundas dos longos séculos de tradição escolástica (CARVALHO, 1978).

No campo educacional da Colônia é necessário ressaltar que a promulgação das aulas régias $^{54}$ (de gramática latina, grega, hebraica e de retórica) em concomitância com a supressão da educação jesuítica em 1759 tinha como justificativa de Estado a "necessidade de se conservarem a união cristã e a sociedade civil” (Idem), argumento que Pombal utiliza para contestar a conduta jesuítica pela acusação de confundirem as regras de sua Constituição com os interesses seculares do papado. Nesse sentido, a Companhia de Jesus foi considerada "símbolo do

\footnotetext{
${ }^{54}$ As aulas régias consistiam em unidades de ensino, com professor único, instaladas para determinada disciplina, que deveriam substituir as disciplinas anteriormente oferecidas pelos colégios jesuítas. Chagas (1980) afirma serem aulas autônomas e isoladas, em que não havia "um currículo, no sentido de um conjunto de estudos ordenados e hierarquizados, nem a duração prefixada se condicionada ao desenvolvimento de qualquer matéria (Apud ZOTTI, 2004. p. 28).
} 
obscurantismo retrógrado, antimoderno, oposto, recalcitrante e ostensivamente, a todas as formas de modernização da cultura" (p. 33).

Ainda segundo o mesmo autor é mister asseverar que o "pombalismo" se justificou como forma de modernização ideológica, política e econômica e que "embora concretizada sob as limitações do absolutismo, traduz as preocupações genéricas do movimento iluminista” (p. 186). Não obstante,

As reformas da instrução pública, nos múltiplos aspectos por que se apresentaram, embora inicialmente determinadas pela pressão dos acontecimentos históricos, constituíram um esforço destinado a fornecer ao poder público os recursos indispensáveis ao progresso do país. (Ibidem)

Este contexto político-ideológico estava alinhado com as questões de ordem econômica uma vez que as reformas postas em curso por Pombal procuraram incentivar o desenvolvimento do setor manufatureiro na metrópole e impedir sua prática na Colônia, estimular a acumulação de capital e substituir as ideologias feudalistas por outras em sintonia com a sociedade capitalista. Assim, urgia, na visão de Pombal, intensificar a produção comercial na Colônia, o que, por sua vez, demandava mais mão de obra, ou seja, mão de obra indígena que até então estava sob controle dos jesuítas e precisavam ser inseridos na economia como escravos, senão de direito, pelo menos de fato (salário simbólico) (CUNHA, 2007). Simultaneamente, o século XVIII assistiu a um crescimento da vida urbana e das atividades administrativas, assim como de uma classe média, situação inédita na sociedade colonial e que exigia padrões culturais até então inexistentes.

Vê-se que num período de grandes transformações sociais, econômicas, políticas e ideológicas a Colônia viu a saída dos jesuítas e com eles de um projeto de educação. Nada foi colocado em seu lugar e o que se viu foi um recrudescimento dos moldes portugueses na formação da elite dirigente colonial, fato que podemos coadunar com manutenção da exclusão das classes populares da educação. Zotti (2004) nos informa que as poucas aulas régias oferecidas serviram apenas para a continuidade da função preparatória de uma minoria que seguiu seus estudos na Europa. Como parece ficar claro, o início da educação pública no Brasil, ou seja, de um processo educativo financiado pelo e para o Estado, não foi dos mais alvissareiro. O ensino secundário, organizado pelo curso de humanidades no período jesuítico, passa a ser conduzido por aulas régias (RIBEIRO, 1992). 
Vê-se que estas mudanças não alteram o fundamental, ou seja, o conteúdo permanece desvinculado dos assuntos e problemas da realidade imediata. Assim, ainda segundo Ribeiro, “o modelo continuou sendo o exterior 'civilizado' a ser imitado" (Idem) e aquela minoria que tinha interesse e recursos poderia enfrentar os riscos da viagem à Universidade de Coimbra ou a outro centro universitário europeu. Portanto, a metrópole, através das reformas pombalinas, não tinha interesse em desenvolver um eficiente sistema educacional na Colônia, mas apenas adaptá-lo à nova ordem da sociedade portuguesa. Azevedo (1976) sintetiza bem esse momento ao escrever que a reforma pombalina

Não só golpeou profundamente, na Colônia, o ensino básico geral, pulverizando-o nas aulas de disciplinas isoladas (aulas régias), sem qualquer plano sistemático de estudos, como ainda cortou, na sua evolução pedagógica normal, o desenvolvimento do ensino para os planos superiores. [...] Tudo, até os detalhes de programa e a escolha de livros, tinha de vir de cima e de longe, do poder supremo do Reino, como se este tivesse sido organizado para instalar a rotina, paralisar as iniciativas individuais e estimular, em vez de absorvê-los, os organismos parasitários que costumam desenvolver-se à sombra de governos distantes, naturalmente lentos na sua intervenção. Esta foi uma das razões pelas quais a ação reconstrutora de Pombal não atingiu senão de raspão a vida escolar da Colônia. (p. 53)

Após estas palavras resta evidente que o período entre a expulsão dos jesuítas e a chegada da Corte ao Brasil em 1808 foi marcado pela ausência de quase meio século de um projeto de ensino para a população colonial, em que a preocupação predominante era garantir o funcionamento do modelo de exploração mercantilista, sustentado pela exploração da mão de obra escrava, a partir da dilapidação da Colônia.

Destarte, a sociedade tem claros contornos excludentes, condizente com o pensamento colonial, e a educação é mais um elemento de sedimentação da segregação social que se apresentava na vida cotidiana. A ação colonizadora, portanto, é essencialmente educativa, colonização e educação se confundem, gestando uma sociedade radicalmente segregada, de fundamentação cristã e submissa às premissas intelectuais medievais. $\mathrm{O}$ currículo, considerando o material disponível, foi elemento central deste projeto educativo colonial, marcadamente enciclopedista, humanista e europeizante, transparecendo a disposição elitista da classe dominante e, simultaneamente, consagra a escolarização como uma espécie 
de dispositivo social que integra saber e poder como estratégia garantidora da ordem dominante.

Não podemos nos furtar de recorrer, mais uma vez, às proposições de Foucault (2007) para perceber que a implantação da escola e o desenvolvimento do processo de escolarização, efetivado pelas orientações curriculares, compõem um jogo de poder que não se limita à instituição escolar nem aos sujeitos envolvidos, mas concentra sua densidade nas relações reticulares entre saber e poder que entrecruzam uma sociedade concebida para ser dominada. $\mathrm{O}$ filósofo francês ao apresentar algumas de suas precauções metodológicas para estudar o "como do poder" nas sociedades ocidentais ensina que a burguesia, especialmente a partir do século XIX, não se importa com os loucos ou com os delinquentes, mas com o poder, mais precisamente "pelo conjunto de mecanismos que controlam, seguem, punem e reformam o delinquente" (p. 186). Ainda que não estejamos tratando de delinquência ou de loucura, o mais importante é pensar que se este raciocínio está correto, o sistema educacional no período colonial brasileiro pode ser considerado como mais um "dispositivo" para "reformar sujeitos" através do processo de escolarização, ou seja, uma rede heterogênea de elementos discursivos e nãodiscursivos que fazem ressoar explicita e implicitamente os desígnios burgueses. Portanto, esta rede se apoiou numa nova economia de poder, segundo o qual "deve propiciar simultaneamente o crescimento das forças dominadas e o aumento da força e da eficácia de quem os domina" (p. 188). Com base nas proposições já assinaladas no capítulo anterior, todo o processo que dá vida à escolarização é materializado no currículo oficial escolar (em suas dimensões prescritas e ocultas), ou seja, o "projeto escolar" iniciado no Brasil pelos jesuítas não é apenas um espelho passivo da sociedade, mas uma força ativa que serviu para legitimar todo o ideário colonial lusitano através da escolarização efetivada pelo currículo.

A expulsão dos jesuítas e as reformas pombalinas em Portugal significaram a desestruturação da educação no Brasil, desassistido de quaisquer propostas que apontassem para a introdução da filosofia moderna e das ciências da natureza, como ocorria na Europa. Em território colonial sobraram apenas as aulas régias para aqueles que precisavam de um mínimo de formação para seguir os estudos do outro lado do Atlântico. Atrelado ao que escrevemos até aqui, o currículo escolar 
evidenciou a visão de mundo do colonizador e procurou formar a classe dirigente para a garantia de uma sociedade dominada política, social e economicamente.

\subsection{Geografia escolar no século XIX: notas de destaque}

Ao voltarmos nosso olhar para o Brasil do século XIX, após a breve contextualização histórica dos séculos anteriores, acreditamos ter alcançado um período de grande relevância para o nosso debate, não apenas pelo fato da disciplina escolar $^{55}$ Geografia surgir no currículo escolar, mas também porque as transformações político-econômicas ocorridas, principalmente no ultimo quartel, atingiram estruturas sociais fundamentais na organização do sistema escolar e na elaboração das premissas curriculares.

A transição do século XVIII para o XIX registra uma série de importantes movimentos de transformação das sociedades ocidentais, como a Revolução Francesa e a Revolução Industrial, cujos impactos se fizeram sentir em diferentes partes do mundo. Portugal, em particular, teve seu território invadido pelo exército francês e precisou encontrar refúgio, sob proteção inglesa, na colônia. A fuga da Corte portuguesa foi acompanhada pela manutenção de sua dependência econômica em relação à Inglaterra, colaborando para a abertura temporária dos portos brasileiros (1808), movimento que, inevitavelmente, coloca o Brasil em direção à outra etapa de desenvolvimento econômico.

À guisa apenas de explicação do contexto político internacional daquele período é importante frisar que a Inglaterra buscava compensar suas derrotas no continente europeu expandindo sua influência nas colônias ibero-americanas, estratégia facilitada pela situação de apuros do monarca português. Neste contexto, segundo Prado Jr. (2012),

\footnotetext{
${ }^{55}$ Cumpre registrar que utilizamos a denominação "disciplina" e não "matéria" ou "aula" ou outra qualquer outra justamente porque em meados da segunda metade do século XIX, na França, uma larga corrente pedagógica procurou evidenciar sua estreita ligação com a renovação das finalidades dos ensinos secundário e primário através da ideia de disciplinar. Este verbo foi entendido inicialmente como sinônimo de ginástica intelectual. Chervel (1990) ensina que durante a década de 1850 , quando se inicia a crise dos estudos clássicos, "os partidários das línguas antigas começam a defender a ideia de que, na falta de uma cultura, o latim traz ao menos uma 'ginástica intelectual', indispensável ao homem cultivado" (p. 179). Com o passar de alguns anos há uma reconsideração profunda da natureza da formação dada ao aluno e em substituição a ideia de "inculcar" se buscou "disciplinar".
} 
A monarquia portuguesa não será daí por diante mais que um joguete nas mãos da Inglaterra. O soberano permanecerá no Rio de Janeiro sob a guarda de uma divisão naval inglesa, aí estacionada permanentemente; e na Europa, serão os ingleses que se incumbirão de dirigir a luta contra a ocupação francesa. (p. 92)

Em acordo com esse novo contexto político-econômico, o Rio de Janeiro passa a sediar grande parte dos órgãos administrativos e judiciários, amplia sua malha urbana e se torna centro da intelectualidade do país. Abrigar a Corte e seu soberano significou uma mudança profunda para a cidade, que passa a se tornar referência da vida política, administrativa, econômica e financeira da monarquia. Dentre as diversas mudanças é interessante destacar algumas voltadas à vida intelectual, como a criação da Biblioteca Pública (1810), da Imprensa Régia (1808), do Jardim Botânico do Rio (1810) e do Museu Nacional (1818).

Todavia, as permanências também são inevitáveis em meio às transformações em curso, como a dependência econômica, mas em relação ao capital inglês, a manutenção do regime monárquico, com o filho do rei de Portugal no trono, e os escravizados ainda na mesma condição, sugerindo que as relações sociais continuavam inalteradas. O mesmo Prado Jr., acerca especificamente da escravidão, escreve que

Realmente a escravidão constituía ainda a mola mestra da vida do país. Nela repousam todas as suas atividades econômicas; e não havia aparentemente substituto possível. Efetivamente, é preciso reconhecer que as condições da época ainda não estavam maduras para a abolição imediata do trabalho servil. (2012. p. 104)

Coaduna-se a essa situação a manutenção da estrutura econômica brasileira nos mesmos moldes do período colonial, ou seja, o latifúndio agroexportador ditava os rumos da política econômica nacional. Acerca desse período, emerge com grande destaque a produção cafeicultora, responsável em grande medida pela recuperação da crise da mineração e encontramos no reconhecido estudo de Celso Furtado sobre a formação da economia brasileira (2005), importantes informações sobre esse período brasileiro. O economista esclarece que a partir do segundo quartel do século XIX há o período de gestação da economia cafeeira, que também registra a constituição de uma nova classe empresarial, enfatizando que a cidade do Rio de Janeiro 
Representava o principal mercado de consumo do país e os hábitos de consumo de seus habitantes se haviam transformado substancialmente a partir da chegada da corte portuguesa. O abastecimento desse mercado passou a constituir a principal atividade econômica dos núcleos de população rural que se haviam localizado no sul da província de Minas como reflexo da expansão da mineração. $O$ comércio de gêneros e de animais para o transporte desses constituía nessa parte do país a base de uma atividade econômica de certa importância, e deu origem à formação de um grupo de empresários comerciais locais. Muitos desses homens, que haviam acumulado alguns capitais no comércio e transporte de gêneros e de café, passaram a interessarse pela produção deste, vindo a constituir a vanguarda da expansão cafeeira. (p. 88)

Este excerto não deixa dúvidas da crescente importância da recente capital do Império e, também, indica quais sujeitos estavam em vias de consolidar um papel de liderança na organização da produção econômica. Furtado fornece algumas informações bastante pertinentes ao nosso estudo ao analisar o processo de formação dos sujeitos que lideraram a economia açucareira no período colonial e os que conduziram a economia cafeeira no século XIX. A classe dirigente açucareira se constituiu quando as atividades comerciais eram monopolizadas por grupos situados em Portugal ou na Holanda, ou seja, "as fases produtiva e comercial estavam rigorosamente isoladas, carecendo os homens que dirigiam a produção de qualquer perspectiva de conjunto da economia açucareira" (Ibidem). Isolados, estas lideranças não tinham uma consciência clara de seus próprios interesses e, como percebemos anteriormente, a escolarização (jesuítica) serviu para garantir o pleno funcionamento desta maquinaria colonial ao desconsiderar por completo todo o contexto político, social e econômico de suas aulas e priorizar o conhecimento teológico e erudito.

A classe dirigente cafeeira formou-se em condições distintas porquanto sua constituição faz referência a uma luta que se estende em uma frente ampla: “aquisição de terras, recrutamento de mão-de-obra, organização e direção dá produção, transporte interno, comercialização nos portos, contatos oficiais, interferência na política financeira e econômica" (Ibidem). Destarte, uma condição básica para este grupo foi a concepção do governo como instrumento de ação econômica, perspectiva que, em nosso entender, impõe o desenvolvimento de um sistema educacional afinado com os interesses da burguesia. Os debates em torno da Constituinte de 1823 estavam prenhes das ideias liberais que dominaram a 
Constituição francesa de 1791, todavia o que se viu foi a dissolução da Assembleia Constituinte e uma Constituição outorgada em 1824, com uma singela menção à política educacional no art. 179:

Art. 179. A inviolabilidade dos Direitos Civis, e Politicos dos Cidadãos Brazileiros, que tem por base a liberdade, a segurança individual, e a propriedade, é garantida pela Constituição do Imperio, pela maneira seguinte.

$[\ldots]$

XXXII. A Instrucção primaria, e gratuita a todos os Cidadãos.

XXXIII. Collegios, e Universidades, aonde serão ensinados os elementos das Sciencias, Bellas Letras, e Artes ${ }^{56}$.

É perceptível que a educação permanecia conduzida pelos interesses da classe dirigente, uma educação restrita às elites. Esta constatação nos remete ao pensamento de Holanda (1995) que ao analisar o período colonial afirma que os portugueses, a rigor, não instalaram uma civilização agrícola, mas uma civilização de raízes rurais, fato que somente será modificado com a abolição da escravatura em 1888. Até então, segundo o supracitado autor,

[...] Eram ainda os fazendeiros escravocratas e eram filhos de fazendeiros, educados nas profissões liberais, quem monopolizava a política, elegendo-se ou fazendo eleger seus candidatos, dominando os parlamentos, os ministérios, em geral todas as posições de mando, e fundando a estabilidade das instituições nesse incontestado domínio. (p. 73)

A passagem da colônia para o Império não representou mudanças significativas no ordenamento político e social e nem mesmo a independência política transformou as estruturas sociais do Brasil. A monocultura agroexportadora, agora cafeicultora, permaneceu predominante na economia, a mão de obra continuou escravizada, ainda que imigrantes tenham desembarcado nos portos nacionais. Por conseguinte, a situação na educação também foi pouco alterada, ou seja, restrita àquelas parcelas privilegiadas da população e de currículo enciclopédico e livresco, conforme prescreveram os jesuítas ${ }^{57}$. Apenas no final da

\footnotetext{
${ }^{56}$ Disponível em: http://www.planalto.gov.br/ccivil_03/constituicao/constituicao24.htm Acessado em: 05/09/2021

${ }^{57}$ Acerca dos estudos de nível médio, segundo Rocha (1996), existiam alguns estabelecimentos que ainda funcionavam nos moldes da tradição jesuítica, mas, de forma geral, predominavam as aulas avulsas do período pombalino (latim, retórica, filosofia, geometria, francês e comércio), que "somadas todas as aulas públicas providas então existentes na Corte e nas províncias, mal se ultrapassava uma centena" (HAIDAR, 1972. Apud ROCHA, 1996. p. 141)
} 
segunda década do século XIX foi promulgada a primeira lei efetivamente voltada à educação e de abrangência nacional.

No interior desse contexto destacamos o decreto imperial de 15 de outubro de 1827 , a primeira lei de instrução elementar do país e única até 1946. A lei assevera que "em todas as cidades, vilas e lugares populosos haverá escolas de primeiras letras quem forem necessárias" e especificamente sobre a matriz curricular afirma que

Os professores ensinarão a ler, escrever, as quatro operações de aritmética, prática de quebrados, decimais e proporções, as noções mais gerais de geometria prática, a gramática da língua nacional, os princípios da moral crista e de doutrina da religião católica e apostólica romana, proporcionadas à compreensão dos meninos; preferindo para o ensino da leitura a Constituição do Império e História do Brasi ${ }^{58}$. (XAVIER, 1992. p. 53)

Com relação à educação das meninas havia a substituição do ensino de geometria por "prendas domésticas" e limitava-se o ensino de aritmética. Assim, a Lei previa que

Haverá escolas de meninas nas cidades, vilas e lugares mais populosos em que os presidentes das províncias, em conselho, julgarem conveniente este estabelecimento. As mestras, além do programa de ensino acima declarado, com exclusão das noções de geometria, e limitando a instrução de aritmética, só as quatro operações, ensinarão as prendas que servem à economia doméstica. (Ibidem)

Resta óbvio a distinção de gênero presente nas orientações curriculares, expondo as funções determinadas pela sociedade para cada gênero. Esta evidente separação sugere não apenas o papel da mulher na sociedade, como coloca a escola como espaço adequado para a construção dessa ação, ou seja, é a escola que deve tornar a então menina apta para as funções sociais que se espera de uma mulher, como também trabalha sua consciência e seu corpo para assimilar sua condição. Destarte, a escola materializa todo um conjunto de valores ideológicos que moldam e estruturam a organização da sociedade, segundo são apregoados pelos ditames hegemônicos, que chegam até os estudantes como uma verdade, práticas e ideias

\footnotetext{
${ }^{58}$ É fato que o ensino de Geografia não estava presente diretamente nos conteúdos escolares das escolas de primeiras letras, todavia é possível afirmar segundo Vlach (edição Kindle, sem datação), sua presença indireta através da história do Brasil e da língua nacional, "cujos textos enfatizavam a descrição do território, sua dimensão, suas belezas naturais".
} 
apresentadas e reproduzidas ao longo de um processo de produção do conhecimento considerado socialmente válido.

Ao retomarmos a fundamentação ontológica (marxista), já apresentada e avançando em nosso estudo, se torna reluzente que o processo de humanização do homem através da produção social da vida material ocorre, em alguma medida, também por meio do currículo escolar. Como é sabido, o ser humano, como ser genérico, se desenvolve no interior das relações produtivas, segundo determinadas condições históricas e materiais, com sua capacidade e necessidade de produção, de apropriação, de transformação, de criação e modificação do meio natural e atividade social, ações que estão, inescapavelmente, orientadas, de alguma forma, nos conteúdos curriculares escolares e podem ser compreendidas como formas de representação da humanização, enquanto uma construção histórica do que deve vir a ser.

Já está posto, de acordo com a corrente teórica adotada, que o processo de humanização é uma realização socioeconômica entremeada por diversas determinações complexas e construídas historicamente pela própria sociedade. Destarte, um dos maiores desafios de nossa proposta é encontrar maneiras de entender como as propostas curriculares implementadas nas escolas estão dialeticamente relacionados às consciências cognoscentes necessárias para uma sociedade de classes. O caminho parece ser, de acordo com Apple (2011) e reforçando aquilo que já defendemos, através “[d]as mediações ideológicas e culturais que existem entre as condições materiais de uma sociedade desigual e a formação da consciência de seus indivíduos” (p. 36).

Por conseguinte, a reprodução das relações sociais de produção precisa estar, a todo custo, assegurada, demandando que as representações simbólicas que os homens fazem das relações de trabalho e de classe também fossem reproduzidas. A burguesia entende a instrução pública, idealizada em seu projeto escolar e assegurada pelo Estado, como um valioso instrumento para a união da sociedade e articulação de seus interesses, conseguindo delimitar um direcionamento comum. 


\subsection{O Colégio Pedro II e a segunda metade do século XIX}

A atenção aos nossos objetivos nos direciona para um período de grande efervescência política no país em meados do primeiro quartel do século XIX e que repercutiu fortemente na organização do sistema escolar. As transformações científicas em curso impactaram a concepção de mundo, a ideia de homem e, como não poderia deixar de ser, as políticas educacionais. Cientes desse contexto histórico, apresentaremos em seguida a organização curricular vigente no ensino secundário brasileiro do século XIX, tendo como referência a criação do Colégio Pedro II, que, como veremos, serviu de parâmetro para os demais estabelecimentos de ensino. Assim, selecionamos alguns momentos de sua estruturação e reorganização curricular que, segundo nossas premissas investigativas, servem de embasamento por refletirem os interesses do Estado concernentes à política educacional e, não obstante, reforçamos que não é interesse nos debruçar sobre a trajetória curricular da Geografia, mas, tão somente, almejamos delinear os pilares históricos que sustentaram a organização curricular até a reordenamento curricular realizado em fins da década de 1990.

É preciso ressaltar, de início, o Ato Adicional de 1834 que instituiu as normas para a descentralização do ensino público, criando as condições para que as províncias legislassem sobre a instrução primária e secundária. A despeito das polêmicas criadas pela promulgação do $\mathrm{Ato}^{59}$, o fato é que as províncias criaram os seus próprios liceus - estabelecimentos de ensino secundário - cuja principal finalidade era a oferta de disciplinas necessárias para os exames de acesso ao ensino superior (SILVA, 2016). Em concomitância, o governo central criou, em 1837, no município da Corte, o Colégio Pedro II, antigo Seminário de São Joaquim, para tentar organizar o ensino secundário, servindo de modelo aos demais

\footnotetext{
${ }^{59}$ Cabe explicitar que o Ato Adicional de 1834 provocou diversas discussões entre políticos, administradores e professores acerca de quem teria o poder de legislar e organizar a educação pública, isto é, se se seria competência do governo geral ou das províncias. A Lei no artigo $10^{\circ} \S 2$ "conferiu às províncias o direito de legislar sobre instrução pública e estabelecimentos próprios a promovê-la, excluindo, porém, de sua competência as faculdades de medicina, os cursos jurídicos, academias até então existentes e outros quaisquer estabelecimentos que, no futuro, fossem criados por lei geral" (HAIDAR, 1972 apud PILETTI, 1987. P. 34). Dessa forma, segundo Piletti (Ibidem), "Na prática, apesar dessa dualidade de competências, o que se verificou foi bem diferente: a atuação do poder central limitou-se ao ensino superior, em geral, e ao ensino primário e secundário no Município da Corte; as províncias limitaram-se a promover, muito precariamente, o ensino primário e secundário dentro de seus territórios, deixando para o poder central o monopólio dos estudos maiores."
} 
estabelecimentos de ensino. É possível afirmar que esta instituição foi a primeira a utilizar legalmente o termo "secundário", conforme consta no seguinte artigo:

O Regente interino em Nome do Imperador o Senhor Dom Pedro II decreta:

Art. $1^{\circ} \mathrm{O}$ seminário do S. Joaquim he convertido em collegio de instrucção secundaria.

(Decreto de 2 de dezembro de 1837 apud SILVA, 2016. p. 39)

Destacamos também que, em relação ao ensino secundário,

A única instituição de cultura geral, criada desde a Independência até a República, foi o Colégio Pedro II, fundado em 1837 (...). Ele foi, desde as suas origens, um grande colégio de humanidades - o mais importante criado pelo governo do Império e, no domínio dos estudos literários, a única instituição de cultura e de formação geral, embora de nível secundário (...). Só uma escola oficial - o Colégio Pedro II - representa os estudos literários e desinteressados, mantendo sempre, em todas as transformações porque passou, o seu caráter de cultura básica, necessária às elites dirigentes do país. (AZEVEDO, 1971, p. 578 apud VLACH, edições Kindle sem datação)

Por conseguinte, segundo Zotti (2004), a promulgação do Ato Adicional efetivou dois sistemas paralelos de ensino secundário: o sistema regular e seriado, como o oferecido pelo Colégio Pedro II, e, eventualmente, pelos liceus provinciais e alguns estabelecimentos particulares; e o sistema irregular, formado por cursos preparatórios para o ingresso no ensino superior, também oferecido pelos estabelecimentos provinciais e particulares. De acordo com esta dualidade, a composição curricular foi diretamente influenciada pelo ensino superior porquanto, em primeiro lugar, "o conteúdo do ensino secundário foi definido em razão do preparo dos candidatos ao ensino superior" e, em segundo lugar, porque "os próprios cursos superiores faziam a seleção dos candidatos e em função de seus próprios critérios" (p. 45). Essa dualidade de sistemas gerou uma certa fragmentação do ensino secundário, impactando o próprio Colégio Pedro II que ao final do Império mantinha seu curso abrangente de sete anos, mas na prática limitava-se a preparar, o quanto antes, os estudantes para os exames de acesso ao ensino superior.

Naquele período resplandecia o caráter propedêutico e enciclopédico de um ensino pretensamente universalista, sinalizando com nitidez um sistema escolar ainda fortemente vinculado a ordem social escravocrata e voltada à formação de 
sujeitos para a elite que compunha a Corte. Destarte, em suma, o ensino secundário serve para atender aos filhos da elite brasileira, seja como preparação para os exames dos cursos superiores, seja para formar a classe dirigente do país. Portanto naquele momento o sentido da educação não se encontrava na formação de um cidadão, mas, a partir de um conteúdo clássico, na manutenção de uma ordenação política, econômica e cultural atinente ao extrato da população dominante.

A observação mais tenta sobre a organização escolar do Colégio Pedro II deixa claro que sua inspiração é francesa. O primeiro regulamento curricular do Colégio Pedro II é de 1838 e reproduz, tal como nos colégios franceses, os estudos seriados e simultâneos, modelo que o poder central impôs como padrão para o ensino secundário. No curso regular havia aulas de línguas (latina, grega, francesa e inglesa), gramática nacional e retórica, geografia, história, ciências naturais, matemáticas, música vocal e desenho (ROCHA, 2014). É interessante trazermos ao texto o artigo $3^{\circ}$ do mesmo decreto de 1837 , que prescrevia: "Serão ensinadas as línguas latina, grega, francesa e inglesa, retórica e os princípios de geografia, história, filosofia, zoologia, mineralogia, botânica, química, física, álgebra, geometria e astronomia" (AZEVEDO, 1971. p. 578 apud VLACH, edições Kindle sem datação).

Assim estava organizado o regulamento:

TABELA PRIMEIRA - Aula $8^{\text {a }}$ e $7^{\text {a }}: 24$ lições por semana: Gramática Nacional (5) ${ }^{60}$, Gramática Latina (5), Aritmética (5), Geografia (5), Desenho (2), Música Vocal (2).

TABELA SEGUNDA - Aula 6a: 24 lições: Latinidade (10), Língua Grega (3), Língua Francesa (1), Aritmética (1), Geografia (1), História (2), História Natural (2), Geometria (2).

TABELA TERCEIRA - Aula $5^{\mathrm{a}}$ e $4^{\mathrm{a}}$ : 25 lições: Latinidade (10), Língua Latina (5), Língua Francesa (2), Língua Inglesa (2), História (2), História Natural (2), Geometria (2).

TABELA QUARTA - Aula 33: 25 lições: Latinidade (10). Língua Grega (5), Língua Inglesa (1), História (2), Ciência Físicas (2), Álgebra (5).

TABELA QUINTA - Aula 2a: 30 lições: Filosofia (10), Retórica e poética (10), Ciências Físicas (2), História (2), Matemática (6).

\footnotetext{
${ }^{60} \mathrm{O}$ número após cada disciplina indica o número de lições semanais.
} 
TABELA SEXTA: Aula 1ª: 30 lições: Filosofia (10), Retórica e Poética (10), História (2), Ciências Físicas (2), Astronomia (3), Matemática (3). (HAIDAR, 1972 apud ZOTTI, 2004. p. 46)

Tem grande simbolismo a presença da Geografia na composição curricular do Colégio Pedro II, uma vez que o colégio foi criado para funcionar também como padrão do ensino secundário do país. Cumpre destacar também que muitas pessoas utilizavam o ensino secundário apenas para chegar ao ensino superior e a Geografia (e História) fazia(m) parte dos exames para as faculdades de direito desde 1831, o que certamente contribuiu para a sua inclusão no currículo do Colégio. $\mathrm{Na}$ engenharia curricular Geografia e História figuraram como duas disciplinas distintas, mas foram ministradas pelo mesmo professor bacharel em Direito, Justiniano José da Rocha.

Não podemos esquecer também que o rótulo Geografia era utilizado tanto para se referir ao objeto Terra quanto para denominar os estudos de descrição e representação do próprio planeta. Por conseguinte, saber Geografia era sinônimo de ter domínio do maior número de conhecimentos possíveis sobre os territórios e seus habitantes. Esta perspectiva encontra respaldo quando vemos que Palacios (1992) assevera que '[...] saber e ensinar 'Geografia' fazia parte das 'novidades' do século, como assim se chamava as ideias modernas ou ligadas à Razão ilustrada" (apud ROCHA, 2014. p. 17 tradução livre).

Podemos enriquecer esta discussão com a análise que Piletti (1987) faz da distribuição das matérias e das aulas semanais em quatro grandes áreas do conhecimento (Humanidades, Matemática e Ciências, Estudos Sociais e outras atividades), mostrando que os Estudos Sociais (Geografia e História) respondiam por apenas 23 lições semanais ou 11,1\% do tempo escolar. Esta área concentrava tempo superior somente ao das "outras atividades" (Desenho e Música) que somavam $6,8 \%$ do tempo. Se compararmos os Estudos Sociais com as Humanidades (Gramática Nacional, Gramática Latina, Latinidade, Grego, Francês, Inglês, Filosofia, Retórica e Poética), que totalizavam 128 aulas semanais ou 61,8\% do tempo escolar ${ }^{61}$.

\footnotetext{
${ }^{61}$ À guisa de complementação é interessante afirmar que a área de Matemática e Ciências (Aritmética, Álgebra, Matemática, História Natural, Ciências Físicas e Astronomia) ocupavam $20,3 \%$ do tempo escolar, num total de 42 lições semanais.
} 
Em 1841 houve uma reorganização curricular no Colégio que reduziu o curso secundário para sete anos, obrigando o estudante a estudar catorze disciplinas no último ano. Também ocorreu a redistribuição das disciplinas e inclusão de novas, como a língua alemã, zoologia, botânica, química, mineralogia e geologia e zoologia filosófica (PILETTI, 1987). Os Estudos Sociais neste novo arranjo sofreram pouca alteração de carga horária ( 24 aulas semanais que correspondiam a $13 \%$ do tempo escolar), todavia uma sutil mudança nos chamou a atenção: a partir daquele momento a disciplina estava renomeada como Geografia Descritiva.

A Geografia escolar praticada no Brasil, como sabemos, estava ancorada naquela praticada na França e que se justificava pela expansão do imperialismo europeu. Destarte, ao que tudo indica, a Geografia escolar brasileira girava em torno de informações gerais sobre um mundo em franco processo de expansão, assistindo a uma elite com dados enciclopédicos. Rocha (2014) destaca que um dos aspectos mais marcantes da Geografia escolar consistia na tradição metodológica adotada pelos professores. O ponto de partida dos estudos deveria ser a partir do mais distante até atingir o mais próximo, assim o mais comum é que os conteúdos programáticos desta disciplina, organizados de forma enciclopédica, "iam desde a descrição da esfera celeste, passando em seguida pela descrição das características naturais e humanas dos diferentes continentes, para somente no fim alcançar a descrição do Brasil”" (p. 17).

Deste modo é possível afirmar, com uma boa margem de segurança, que o ensino de Geografia permaneceu basicamente o mesmo ao longo de todo o período imperial e de boa parte do republicano, predominando a tradição descritiva, mnemônica, enciclopédica. A manutenção da metodologia e dos conteúdos evidencia que o currículo prescrito conservou seus aspectos mais evidentes e, por conseguinte, o reflexo de uma sociedade ainda em vias de transformação.

É importante destacar que a Geografia ensinada no Brasil reproduzia ipsis litteris os conteúdos ensinados na França, o que, de forma alguma, incentivaria um sentimento patriótico em favor do Estado-nação brasileiro. Ademais, a inexistência até a década de 30 do século XX de um sistema nacional de educação e o pequeno contingente populacional que frequentava as instituições escolares não serviriam a um intento nacionalista. Nesse contexto, se o acesso aos conhecimentos escolares era bastante restrito, voltado a um extrato privilegiado da sociedade, pensamos que 
o conhecimento geográfico escolar consistia em mais uma ferramenta de afirmação da superioridade burguesa sobre o restante da sociedade. Obter informações sobre outros territórios ou ter domínio sobre outros idiomas ou ainda realizar operações matemáticas representava estar numa posição de destaque na sociedade, prosperando a cargos e empregos de reconhecimento público, enquanto os demais estavam disponíveis a subalternização.

Esta realidade representava uma sociedade ordenada que se preparava para a conservação desta ordem, ou seja, os currículos escolares deveriam garantir que quem os conhecessem se tornassem aptos a manter a mesma estrutura social já edificada. Se o objetivo precípuo da Geografia não era difundir o nacionalismopatriótico, então entendemos ser a consolidação da ideia de que o sujeito moderno burguês tem garantido seu lugar na sociedade, não apenas pelo conhecimento de informações sobre os diferentes locais do planeta, mas pela reprodução de uma ideologia que encontra as consciências dos estudantes e, ao mesmo tempo, dos excluídos da educação porquanto para todos a mensagem é a mesma: estudar é privilégio. Apple (2011) complementa nossa proposição ao escrever que "o currículo das escolas responde a recursos ideológicos e culturais que vêm de algum lugar e os representa" (p. 84).

É interessante retornarmos à trajetória de transformações curriculares enfrentadas pelo Colégio para não perdermos de vista o contexto histórico que nos cerca. Algumas reorganizações curriculares foram implementadas, como em 1854, 1855,1857 e 1862, sem que mudanças radicais fossem sentidas (PILETTI, 1987) e que conduziram até a década de 1870, quando ganhou corpo o debate em torno do ensino científico. As elites nacionais passaram a defender a elevação do país ao nível do século através de uma educação secundária assentada no ensino científico $^{62}$. Rocha (1996) escreve que essa mudança é derivada do desejo de "formar integralmente o cidadão, em oposição às velhas finalidades da nossa escola

\footnotetext{
${ }^{62}$ Não podemos esquecer que reformas posteriores também foram efetivadas em 1876, 1878 (esta, em particular será tratada com maior minúcia mais à frente), 1881, todas, em suma, foram resultado das discussões empreendidas na Europa, onde dois grupos defendiam propostas distintas para o ensino secundário: os defensores do ensino científico e os defensores do ensino humanístico. A solução encontrada foi a diversificação dos estudos secundários, contemplando ambas propostas e materializando a perspectiva teórico-prática dual do ensino secundário: "às humanidades continuaria reservada a missão de formar integralmente o homem; à ciência incumbiria a tarefa de prepará-lo praticamente para as novas necessidades da sociedade moderna" (HAIDAR, 1972 apud ZOTTI, 2004. p. 56).
} 
secundária que nada mais era do que preparar para o ingresso no ensino superior", sugerindo, por conseguinte, que a escola secundária deveria "dar a preparação básica para as necessidades complexas e variadas da vida social” (p. 169). Consoante a esta nova demanda, em 1870 entrou em vigor um decreto que reformou o ensino e chama a atenção a justificativa apresentada pelo Ministro Paulino de Souza:

\begin{abstract}
A instrução secundária é dos três [ramos da instrução pública] o que mais influi na educação, formando a inteligência e em grande parte o caráter dos que a recebem. Nela não enxergo tamanho alcance pelos conhecimentos que adquire o aluno, como pelo desenvolvimento intelectual e qualidades de espírito que obtém por meio do estudo das matérias que o constituem [...]. Não importa tanto que nas línguas estrangeiras o aluno obtenha um vocabulário mais ou menos completo, que nas ciências fique com mais ou menos algumas noções, como que consiga o resultado de exercitar, adestrar e alargar o espírito, dispondo-o pela aquisição dos dotes necessários para estudos de aplicação e interesse prático. Eis porque, na reforma do plano de ensino do Imperial Colégio de Pedro II, procurei tornar mais rigoroso o estudo daquelas matérias que tendem a desenvolver o espírito do aluno na idade em que mais facilmente se pode dirigir, e não exigir provas tão severas nas matérias que tendem mais a enriquecer a inteligência do aluno do que a robustecê-la. (HAIDAR, 1972 apud ROCHA, 1996. p. 170 grifos nossos)
\end{abstract}

Transparece com alguma nitidez que a proposta do Ministro tem como cerne atingir o espírito, ou, como preferimos, a consciência do aluno na idade que "mais facilmente se pode dirigir" justamente porque o currículo escolar, chamado de plano de ensino, tem esse poder de mobilizar a escolarização para que um objetivo seja atingido. Neste caso em particular, como já salientamos, defendemos que o todo o parco aparato educacional brasileiro estava prioritariamente voltado para a garantia da imobilidade social, ou melhor, para que as estruturas sociais herdadas do período colonial permanecessem intactas. Emerge, portanto, uma dupla função: garantir o acesso ao conhecimento apenas para os privilegiados e difundir um conhecimento que garanta a reprodução da sociedade. Os excluídos do sistema educacional, mesmo sem frequentar as cadeiras escolares, aprenderam desde cedo qual deveria ser o seu lugar na sociedade e, ao mesmo tempo, endossaram uma sociedade socialmente segregada. Por outro lado, os privilegiados entenderam o seu papel na condução da sociedade e adquiriram conhecimentos que não apenas robusteceram sua erudição, como também justificavam seus privilégios. 


\subsubsection{Os pareceres de Rui Barbosa}

Carlos Leôncio de Carvalho, Ministro da pasta de Negócios do Império, que na época era responsável pelos assuntos concernentes à educação, realizou uma reforma no Colégio Pedro II que, podemos considerar, agravou o modelo de educação secundária imperial. Este ministro estava imbuído de ideias liberais e autorizou, entre outras medidas, a liberdade de frequência, ou seja, permitiu que qualquer pessoa pudesse se submeter aos exames vagos de qualquer ou de todas as disciplinas, mesmo sem ter assistido as aulas. Estava previsto ainda o recebimento do grau de "bacharel em letras" a todos aprovados nos testes, mesmo sem ter frequentado nenhuma aula (HAIDAR, 1972 apud ZOTTI, 2004. p. 60). É perceptível a iniciativa de estimular os estudos fragmentários com a multiplicação das bancas e épocas de exames, prazo ilimitado da validade dos exames, bem como com as matrículas parceladas (PILETTI, 1987).

O novo regulamento estabeleceu a duração do curso em sete anos, a ampliação dos estudos literários com a inclusão do italiano e revelou também uma preocupação com os estudos científicos pela adoção de materiais necessários ao ensino de ciências e a desobrigação do ensino religioso. No que se refere ao ensino de Geografia, a disciplina foi deslocada para os primeiros dois anos do curso. Assim ficou organizado os anos de estudos:

\footnotetext{
$1^{\circ}$ ano - Latim; Francês; Geografia; Aritmética.

$2^{\circ}$ ano - Latim, Francês; Geografia; Aritmética.

$3^{\circ}$ ano - Latim; Inglês; Álgebra; Italiano.

$4^{\circ}$ ano - Alemão; Inglês; História Antiga e Média; Geometria no espaço e Trigonometria retilínea.

$5^{\circ}$ ano - Alemão; História Moderna e Contemporânea; Física e Química; Cosmografia; Grego; Filosofia; Retórica, Poética e Literatura Nacional; História Natural.

$6^{\circ}$ ano - Não consta na fonte de pesquisa.

$7^{\circ}$ ano - Grego, Filosofia; História e Corografia do Brasil; Português e Literatura Geral (HAIDAR, 1972 apud ZOTTI, 2004. p. 61)
}

No ano seguinte, o Ministro Leôncio baixou um decreto para normatizar o ensino primário e secundário no município do Corte, os exames preparatórios e reformar o ensino superior em todo o país. A opção pelo decreto foi escolhida para evitar as prolongadas discussões e oposições que normalmente surgiriam numa tramitação usual de projeto, todavia somente os itens que não provocassem aumento 
de despesa poderiam ser imediatamente efetivados. $\mathrm{O}$ decreto, todavia, precisava ser apreciado pela comissão de Instrução Pública da Câmara dos Deputados, que deveria elaborar um parecer que subsidiasse as discussões a serem realizadas pela Câmara. O relator da comissão era Rui Barbosa que, juntamente com outros dois deputados (Thomaz de Bonfim Spindola e Ulysses Machado Pereira Vianna), ofereceu dois pareceres: um sobre o ensino secundário e superior e outro sobre o ensino primário ${ }^{63}$ (ROCHA, 1996). Não é demais salientar que não temos a intenção de desenvolver uma prolongada discussão acerca destes pareceres, mas apenas apresentar as considerações mais pertinentes ao tema e que fortalecem nossas premissas teóricas, especialmente aquelas estritamente relacionadas à disciplina escolar Geografia.

Com o simples objetivo de adornar a discussão, entendemos ser interessante mencionarmos um pequeno trecho do parecer acerca da importância da expansão do ensino. O relator e os demais deputados revelam ter bastante clareza do poder mobilizador da educação e de sua necessária expansão ao apontarem, no capítulo que versa sobre o "Imperial Lyceu Pedro II", que é fundamental a sua conversão de externato num grande modelo nacional, que represente não apenas o ensino secundário de acordo com as ideias científicas, mas que também franqueie a todas as classes da população o ensino técnico para várias carreiras industriais. Resta óbvio que os pareceristas defenderam um tipo de escola para as classes privilegiadas - de ensino mais científico, humanista e erudito - e outra para as classes populares - técnica, profissionalizante - todavia o que nos interessa é a argumentação em favor de aumento dos investimentos públicos na educação, algo que já naquela época parecia ser algo difícil. No parecer há uma explícita convocação da classe política ao "derramamento do ensino", ou seja, a consideração de que o cálculo financeiro precisa priorizar o recrudescimento do sistema educacional para o bem do país. O trecho a seguir é bastante elucidativo:

A base de todo o calculo financeiro está na producção; e a producção, é, no sentido mais scientifico, mais real, mais pratico da palavra, é, para nos servimos da expressão de Horace Mann, 'obra da intelligencia'. Todos abstractamente estão dispostos a render homenagem a esta verdade, mas quasi ninguem, neste

\footnotetext{
${ }^{63}$ Para sustentar nossa argumentação utilizaremos o próprio documento referente ao ensino secundário que está disponibilizado no seguinte endereço eletrônico: http://www2.senado.leg.br/bdsf/handle/id/242371
} 
paiz, lhe é fiel, ou sequer a comprehende. De attestar que a educação é a matriz da felicidade universal humana, qualquer estadista nosso se honraria; mas transportem-se da rhetorica aos factos, e verão que a phrase não passa de um desses aphorismos couvencionaes, de mero apparato decorativo na eloquência dos oradores, e simples engodo na boca dos políticos, para armarem as sympathias da opinião, a quem são sempre aceitas as causas nobres, os sentimentos generosos. O de que nós precisamos, é de homens de estado, que se convençam, effectivamente de que a suprema necessidade actual da pátria está na creação do ensino. (BARBOSA et al. 1882. p. 37)

No que tange à Geografia encontramos um parecer bem mais amplo nas Obras Completas de Rui Barbosa, acerca da reforma do ensino primário em que o renomado relator procura inspiração nas nações do "mundo civilizado" para redirecionar a educação brasileira. Barbosa discorre acerca da Geografia escolar e defende sua aplicação em sintonia com a Geografia científica e com os métodos mais modernos de ensino. O relator exalta a importância da disciplina ao escrever que "este elemento indispensável da instrução comum vai produzindo, por toda parte, frutos consideráveis", assegurando que "o estudo de geografia constitui, hoje mais do que nunca, um elemento essencial da educação comum" (1946. p. 293).

Barbosa com os demais deputados fazem algumas indicações bastante interessantes ao nosso estudo quando, após divagarem sobre o ensino de Geografia em alguns países europeus e nos Estados Unidos, elencam a (preocupante) realidade brasileira com base em um dos manuais elementares de Geografia ${ }^{64}$. A descrição apresentada é minuciosa e ilustrativa:

Depois de algumas definições geométricas, que ocupam as duas primeiras páginas do texto, outras definições constituem o intróito: definição da geografia, das linhas e círculos do globo, dos polos, de horizonte, clima, latitude, longitude e estacoes do ano, continente, região, país, ilha, península, cabo, istmo, monte, montanha, serra, vulcão, mar, oceano, golfo, estreito, mancha, passo, lago e rio. (Idem, p. 305)

\footnotetext{
${ }^{64}$ É importante esclarecer que Barbosa e os demais deputados estão dedicados à instrução primária e ainda que este não seja nosso escopo investigativo entendemos ser lícito tomarmos este parecer como referência porque a descrição da disciplina Geografia no currículo do ensino secundário é bastante semelhante ao que era apresentado nesta primeira etapa educativa. Ademais, os princípios norteadores da ciência e os pilares políticos do sistema educacional brasileiro, pelo menos de acordo com nossa pesquisa, não apresentaram mudanças significativas entre os conteúdos abordados na educação primária e secundária.
} 
Cada definição apresentada sugeriu que a disciplina escolar Geografia tinha como objetivo principal fornecer o maior número possível de informações para os estudantes, função que podemos considerar importante para quem frequentava os estabelecimentos de ensino, mas que muito pouco realmente servia para a compreensão do espaço. Neste sentido, a disciplina, manifestada em seu currículo escolar, consistia apenas num grande baú de informações a serem oferecidas aos estudantes. É evidente que naquele momento a ciência geográfica ainda não havia em suas discussões epistemológicas e escolares, no entanto, como bem nos mostra Barbosa, seu caráter abstrato, distanciado da realidade do aluno, "enfiando este rosário de abstrações ininteligíveis ao espírito despreparado da criança" já era razão para críticas e desejo de mudanças.

Neste momento entendemos ser importante destacar como a disciplina escolar Geografia praticada ao longo do século XIX, sob o pretexto de apresentar "a realidade conhecida", arremessava o espaço numa névoa de aparências fenomênicas de feições já acabadas e, simultaneamente, impedia qualquer outra interpretação do espaço. O currículo, por seu turno, representava esta concepção da ciência geográfica e da Geografia escolar, alavancando um estudo de definições das paisagens e de descrições dos locais que consagravam a disciplina no altar positivista das ciências, mas distantes da vida do espaço. Assim, o método científico unificado, o método das ciências naturais, estimulou uma naturalização dos fenômenos sociais e sua reprodução pela sociedade se deu, em grande medida, por meio das carteiras escolares.

Barbosa era um defensor da ciência moderna e, por conseguinte, arguia em favor de um ensino de geografia obediente ao método racional preconizado pelo positivismo. Destarte, todas as definições abstratas deveriam ser deletadas e em seu lugar emergia a realidade, ou a sua imagem concreta, sensível, nítida, a fonte exclusiva de toda a cultura geográfica (ROCHA, 1996). É importante ressaltar que a geografia escolar proposta por Barbosa (1946) atribuía destaque ao homem, como ele demonstra ao escrever que

"Até hoje", dizia, há dez anos, Michael Bréal, "o homem está ausente de nossos livros de geografia; e, todavia, ele é o verdadeiro e principal objeto desse estudo. De um lado, a geografia deve apresentar as mudanças a que submetem o homem a situação, o clima, a configuração e a natureza da terra 
habitada por ele; do outro, há de mostrar as modificações que ele mesmo imprime ao solo, e ao proveito que extraiu de sua vivenda terrestre $[\ldots] ”$. (p. 313)

A perspectiva trazida pelo supracitado autor confirma o seu desejo de introdução no currículo escolar de uma orientação moderna e positivista. Ainda que as proposições de Barbosa não tenham sido levadas a cabo é importante, pensando em nossos objetivos, fazermos uma reflexão relacionando estas ideias com a questão ontológica. Não podemos esquecer que o recrudescimento da epistemologia científica moderna opera uma cisão entre o sujeito e o objeto do conhecimento, conforme assinalamos alhures. Neste contexto científico, a separação entre a res cogitans e res extensa indica que tudo no mundo é espacial, menos o "eu" e esta concepção "contamina" o ensino de Geografia porque instaura uma ontologia fundamentada na completa dualidade entre o sujeito e o espaço. Por conseguinte, o estatuto científico moderno impôs ao sujeito pensante seu afastamento do objeto de estudo, procedimento que verificamos a partir dos currículos escolares de Geografia do século XIX e também com a denúncia de Barbosa.

Portanto, entendemos que a disciplina escolar Geografia, acompanhando os fundamentos da sociedade brasileira, manteve-se basicamente a mesma em seu conteúdo e em sua forma de ensinar. As aulas de Geografia permaneceram com seus tons descritivos, mnemônicos, enciclopédicos e distanciadas da realidade discente. Estes aspectos começaram a ser questionados no final do século XIX, não a partir da própria Geografia escolar brasileira, mas das transformações mais amplas ocorridas no ensino desta disciplina no exterior (ROCHA, 1996), conquanto os fundamentos ontológicos permanecessem intactos.

O Brasil do final do século XIX viu as oligarquias latifundiárias e a cada vez maior burguesia urbana vociferarem aos quatro ventos a garantia da educação como artigo de luxo restrito às classes dominantes, especialmente o ensino secundário e superior. É bastante ilustrativo o caso do ensino primário, que teve todas as suas propostas de regulamentação fracassadas e permaneceu o entendimento de que a instrução elementar é uma prerrogativa da família, seguindo a tradição aristocrática colonial. A visão de mundo elitista ganhou contornos ainda mais concretos com a promulgação da Constituição de 1891, que reafirmou a descentralização escolar, já definida em 1834, atribuindo aos estados a 
responsabilidade de manter e legislar sobre o ensino primário e o ensino profissional. Destarte, a oligarquia cafeeira, sustentada pelo federalismo e autonomia dos estados, estava desobrigada de elaborar e propor políticas educacionais, resultando, consequentemente, na consolidação das discrepâncias regionais e na precariedade do ensino primário.

O ensino secundário, por sua vez, continuava estreitamente vinculado ao ensino superior e sua composição curricular foi definida em função dos exames admissionais das universidades. Em suma é possível inferir que a organização escolar, em todas as suas dimensões, refletia as contradições da sociedade brasileira, política e economicamente excludente, produto de uma civilização baseada na escravidão.

\subsection{O novo século e as transformações que não alteram}

A expressiva expansão das forças produtivas e o progresso material registrados no final do século XIX mereceram o reconhecimento dos historiadores, como assinala Prado Jr. (2012). O advento da República e os anos subsequentes apontam para o apogeu da produção extensiva e em larga escala, de matérias-primas e gêneros tropicais destinados à exportação. Acerca deste próspero período, o supracitado autor destaca a concorrência de fatores externos e internos, como o

O grande incremento adquirido pelo comércio internacional; era o fruto do considerável desenvolvimento da população européia e norte-americana em particular, da ascensão do seu nível de vida, da industrialização, e finalmente, do aperfeiçoamento técnico, tanto material - os sistemas de transporte - como da organização do tráfico mercantil e financeiro. E tudo isto condicionado e estimulado pelo amplo liberalismo econômico que proporcionava a todos os países e povos da terra uma igual e equitativa oportunidade comercial. Como resultado disto, alargavam-se os mercados para as matérias-primas e gêneros alimentares tropicais de países como o Brasil. (p. 154)

O positivo cenário econômico não é suficiente para elidir as diversas contradições que resultaram na Proclamação da República, com destaque para as disputas entre senhores e escravizados que sugeriam uma necessária transformação das relações sociais e, consequente, modernização do Estado capitalista. Esse conflito pode ser considerado raiz da divergência entre a elite cafeeira, escravagista 
e interessada na defesa da estrutura social colonial; e a burguesia, favorável a libertação dos escravizados e do trabalho assalariado. Grande parte deste desentendimento residia, portanto, na questão da mão de obra, tema que foi aparentemente solucionado pela remoção do obstáculo ao desenvolvimento trabalho livre (1888) e pela corrente regular de trabalhadores europeus por meio de uma imigração subvencionada.

A República recém instaurada adveio, de fato, de um golpe militar com pouquíssima participação de grupos civis e sem nenhuma interferência popular. Mais uma vez recorremos às palavras de Prado Jr. (Idem) para apresentar algumas mudanças na sociedade brasileira que nos são relevantes:

[...] A República agiu como bisturi num tumor já maduro; rompeu bruscamente um artificial equilíbrio conservador que o Império até então sustentara, e que dentro de fórmulas políticas e sociais já gastas e vazias de sentido, mantinha em respeito as tendências e os impulsos mais fortes e extremados que por isso se conservavam latentes. Estes se fazem então sentir com toda sua força longamente reprimida, abrindo perspectivas que a monarquia conservadora contivera ou pelo menos moderara muito. No terreno econômico observaremos a eclosão de um espírito que se não era novo, se mantivera no entanto na sombra e em plano secundário: a ânsia de enriquecimento, de prosperidade material. Isto, na monarquia, nunca se tivera como um ideal legítimo e plenamente reconhecido. $\mathrm{O}$ novo regime o consagrará. O contraste destas duas fases, anterior e posterior ao advento republicano, se pode avaliar, entre outros sinais, pela posição respectiva do homem de negócios, isto é, do indivíduo inteiramente voltado com suas atividades e atenções para o objetivo único de enriquecer. No Império ele não representa senão figura de segundo plano, malvista aliás e de pequena consideração. A República levá-lo-á para uma posição central e culminante. A transformação terá sido tão brusca e completa que veremos as próprias classes e os mesmos indivíduos mais representativos da monarquia, dantes ocupados unicamente com política e funções similares, e no máximo com uma longínqua e sobranceira direção de suas propriedades rurais, mudados subitamente em ativos especuladores e negocistas. Ninguém escapará aos novos imperativos da época. (p. 155)

No entanto, é preciso iluminar que a implantação do regime republicano não provocou a destruição dos clãs rurais e o fim dos grandes latifúndios, verdadeiros sustentáculos materiais do sistema político praticado e que tinha no chamado 
"coronelismo"65 sua principal expressão. O coronelismo é permanentemente alimentado pelo recrudescimento das oligarquias regionais e alcança ponto máximo com a "política dos governadores", ou seja, a instituição do pacto federativo obrigou o novo regime a recorrer às forças dos coronéis. Nagle (1976) escreve que a "Federação, portanto, traduziu no plano político as condições objetivas da estrutura agrária dominante" (p. 4).

Ao aparente "otimismo" de Prado Jr., na dimensão econômica, precisamos acrescentar a crítica política acerca do incipiente período republicano porquanto o que se observou, na prática, foi o continuísmo ou o imobilismo das estruturas sociais brasileiras. Esta constatação é facilmente verificável quando observamos que já 1894, com a eleição do paulista Prudente de Morais, primeiro presidente civil, estava inaugurada o rodízio mineiro-paulista na presidência, ou seja, a “política dos Estados" (ou dos "governadores") foi traduzida em política do cafécom-leite. Construída sobre o coronelismo, a instituição oligárquica definiu um sistema de representação coletiva bastante particular, limitando as determinações a um restrito grupo político que perpetuava a mesma composição do poder.

É no interior dessa realidade que não apenas a educação, mas também outras questões de âmbito nacional, como a democracia ou a industrialização, foram deixadas em segundo plano pelas oligarquias regionais, preocupadas em garantir as raízes rurais da sociedade. Condizente com essa prerrogativa, a ladainha da educação como artigo de luxo exclusivo das classes privilegiadas continuou a ser entoado, o que significou a manutenção do destaque ao ensino secundário e superior e o abandono do ensino primário (ZOTTI, 2004). O período da Primeira República, portanto, consagrou o sistema dual de ensino existente desde o Império, consistindo, na prática, na distância entre a educação da classe dominante (escolas secundárias e escolas superiores) e a educação do povo (escola primária e escola

\footnotetext{
${ }^{65}$ De forma bastante sucinta podemos afirmar, apoiados na obra de Vitor Nunes Leal (2012), que o coronelismo consiste sobretudo em um "compromisso, uma troca de proveitos entre o poder público, progressivamente fortalecido, e a decadente influência social dos chefes locais, notadamente dos senhores de terras. Não é possível, pois, compreender o fenômeno sem referência à nossa estrutura agrária, que fornece a base de sustentação das manifestações de poder privado ainda tão visíveis no interior do Brasil" Paradoxalmente, esta base material privada é alimentada pelo poder púbico "justamente em função do regime representativo, com sufrágio amplo, pois o governo não pode prescindir do eleitorado rural, cuja situação de dependência ainda é incontestável". Nesse contexto, emergem características secundárias "o mandonismo, o filhotismo, o falseamento do voto, a desorganização dos serviços publico locais” (p. 23).
} 
profissional), ou seja, refletia a própria dualidade presente na organização da sociedade brasileira.

As transformações socioeconômicas em curso, especialmente a crescente atividade industrial por volta de 1920, assistem a emergência de uma burguesia industrial, do proletariado e de uma classe média em oposição às decadentes oligarquias cafeeiras. Inegavelmente esta nova correlação de forças sociais e econômicas influenciaram decisivamente em diversos setores da sociedade, como na educação, fato que, pelo menos num primeiro momento, pouco impactou a organização do ensino secundário. Este permaneceu distante do centro das políticas educacionais implementadas pelos republicanos, conforme afirma Souza (2008)

Tratava-se da educação de um grupo social muito restrito, jovens herdeiros da oligarquia agrária, filhos de industriais, grandes comerciantes, profissionais liberais ou da incipiente classe média urbana, cuja formação fundamentada nos estudos desinteressados expressava a distinção cultural de uma elite, destinando-se a uma finalidade muito específica, isto é, a preparação para os cursos superiores. Assim, os vínculos da escola secundária com o processo de modernização da sociedade brasileira nos primórdios da república foram concebidos em outros termos. Significava a manutenção de uma alta cultura assentada sobre a conciliação precária entre estudos literários e científicos, prevalecendo, não obstante, os primeiros (p. 89 apud SILVA, 2016. p. 40)

Cumpre realçar também a penetração do ideário liberal na sociedade brasileira, cujas premissas remetem ao individualismo, a liberdade, a propriedade, a igualdade e a democracia. Cunha (2007) é bastante claro ao afirmar que

No que se refere à educação, a doutrina liberal postula a independência da escola diante dos interesses particulares de classe, credo religioso ou político. A escola é vista como tendo a função de despertar e desenvolver os talentos e as vocações dos indivíduos na medida de suas características inatas, de modo que eles possam se posicionar na sociedade conforme suas aquisições e não conforme a herança de dinheiro ou de títulos. (edições Kindle, sem paginação)

Os ideais liberais não atingiram de forma consistente a política educacional brasileira, tema que permaneceu marginalizado e que manteve a escola como privilégio das classes dominantes. Nagle (1976) não deixa dúvidas quando afirma que 
O renascimento dos ideais liberais não deve ser julgado independentemente de mudanças que operavam ao nível dos setores econômicos e sociais. A clarinada liberal precisa ser combinada com duas ordens de ocorrência. De um lado, com a passagem do sistema agrário-comercial para o sistema urbanoindustrial, que se vai processando no tempo; de outro lado, rompem-se os alicerces da sociedade estamental e se estruturam as bases de uma sociedade de classes. Interpenetram-se, assim, os três níveis de realidade. Ao mesmo tempo que se interpenetram, provocam a mobilidade estrutural que vai definir o período como de mudança, caracterizado pelo estabelecimento mais firme de requisitos de uma nova fase de Capitalismo. (p. 97/98)

A educação, como se vê, mudou muito pouco nos primeiros anos do século XX, assinalando uma espécie de descolamento da educação em relação ao contexto mais amplo do país. Tal fato é consequência da continuidade das mesmas estruturas herdadas da sociedade escravocrata, em que o poder político permanecia concentrado nas mãos da oligarquia rural. Era este pequeno grupo o responsável pela elaboração das legislações nacionais, inclusive da educação, situação que assegurava um sistema escolar de mesma mentalidade do período colonial, ou melhor, um sistema escolar que se estruturava sobre raízes rurais. Interessante trecho do estudo de Nogueira (1993) esclarece esta situação ao mostrar que

\begin{abstract}
Particularmente no caso do Brasil, por exemplo, as camadas ilustradas, apesar da ideologia liberal importada através da literatura e por elas apreendida no estudo dos movimentos políticos ocorridos na Europa e nos Estados Unidos, continuavam a acreditar em elite dominante e povo dependente e submisso como uma dicotomia inevitável no processo civilizatório. Esses intelectuais internalizavam os postulados políticos da classe dominante que, embora traduzissem ideias liberais enquanto discurso, eram, na prática muito mais favoráveis à manutenção da estrutura sociedade colonial e à viabilização do modelo de dominação política oriundo das relações entre as oligarquias e o Estado. (p. 83 apud ROCHA, 1996. p. 195)
\end{abstract}

Todavia, o início da República brasileira é notadamente marcado por reformas educacionais. Cinco reformas se sucederam desde a Proclamação da República até a Revolução de 1930 - Reforma Benjamin Constant (1890) ${ }^{66}$,

\footnotetext{
${ }^{66} \mathrm{O}$ programa curricular implementado por esta reforma em quase nada alterou os programas adotados durante o regime imperial. É válido mencionar a centralização na produção e difusão dos compêndios e livros adotados nas instituições escolares pelo governo central, cujo objetivo era manter o controle curricular, ou mais precisamente, o domínio exclusivo na seleção de conteúdos que garantisse a veiculação de temas considerados oficialmente dignos de serem ensinados e,
} 
Reforma Epitácio Pessoa $(1901)^{67}$, Reforma Rivadávia Corrêa $(1911)^{68}$, Reforma Carlos Maximiliano (1915) ${ }^{69}$ e a Reforma Luís Alves/ Rocha Vaz (1925), esta última certamente a mais importante para nosso estudo até aqui porque foi a partir dela que de fato se procura fundar uma Geografia moderna nas escolas.

Com o fito de não prolongarmos em demasia a discussão desse período da Primeira República faremos uso das palavras de Nagle (1976) que sintetiza bem o que foram os primeiros trinta anos republicanos do Brasil com relação a educação:

[...] De 1890 a 1920, os planos de estudos prestigiam tão-somente as disciplinas tradicionais (línguas, matemáticas, ciências, conhecimentos de Geografia e História), com predominância dos estudos literários sobre os científicos. Embora não se refiram a nenhuma formação profissional específica, tais disciplinas têm um valor preparatório geral ou formativo diante das especializações do ensino superior. Neste caso, não se justificam as propostas atinentes à introdução de disciplinas técnicas no curso ginasial, ao desdobramento deste curso em estruturas similares ou à sua divisão em ciclos e seções. Além de pedagógicas, de natureza disciplinar, razoes sociais mais profundas fundamentam a cultura geral - intelectualista e enciclopédica, desinteressada e aristocrática - que o ensino secundário brasileiro ministra ao longo das três primeiras décadas republicanas. Com uma estrutura curricular única e integral, de 7, 6 ou 5 anos de duração, o secundário representa, com efeito, a instituição mais eficaz quanto aos propósitos de uma educação "de classe". No decorrer das reformas, a reação que se verifica a alterações curriculares - alterações qualitativas - constitui, de fato, uma resistência a que os estudos secundários se estendam a uma clientela de níveis sociais cada vez menos elevados. (p. 147)

consequentemente, "a nova legislação dava sua parcela de contribuição para a naturalização dos conhecimentos resultantes da 'tradição seletiva' que há muito vinha sendo implementada (ROCHA, 1996). Particularmente com relação à Geografia, as bases científicas modernas permaneceram ausentes e persistiram o enciclopedismo e a descrição livresca.

${ }^{67}$ Esta reforma buscou aprofundar a tendência de centralização, colocando sobre as escolas um maior controle através de medidas federais fiscalizadoras e uniformizadoras. Acerca da Geografia, a única mudança significativa foi sua restrição aos três primeiros anos do ensino secundário.

${ }^{68} \mathrm{O}$ principal objetivo desta reforma foi a implementação de uma política descentralizadora, ou seja, é atribuída a todos os institutos escolares autonomia na organização de seus programas de ensino e o Colégio Pedro II perde sua condição de destaque no seio do ensino secundário nacional. No que concerne à Geografia continuou o ensino de realidades distantes e descontextualizados, como preconizado desde o Império.

${ }^{69}$ Acusada de provocar um verdadeiro caos no sistema educacional brasileiro, a reforma Rivadávia Corrêa é rapidamente substituída por outra, que recoloca o Colégio Pedro II como modelo e retomou várias medidas das reformas anteriores, como o ensino disciplinar, seriado e a tolerância com os cursos preparatórios. Até então, todas as reformas são caracterizadas pelo seu extremo burocratismo, isto é, não se discutia como ampliar a escolaridade ou como alcançar os grupos marginalizados. 
A Reforma Luís Alves/ Rocha Vaz representou um movimento de transformação da Geografia escolar, fazendo emergir um novo paradigma para o ensino desta disciplina. Antes de adentrarmos com maior profundidade nesta questão é necessário contextualizarmos melhor a situação do país, uma vez que são processos imediatamente correlacionados. A década de 1920 assistiu a um crescimento da atividade industrial no país, muito em virtude da primeira Grande Guerra (1914-1918), uma vez que a importação dos países beligerantes despenca, mas também por causa da forte queda do cambio que reduz consideravelmente a concorrência estrangeira (PRADO JR. 2012). O mesmo autor assevera que

Chegada a este ponto de desenvolvimento, a indústria passara já a ocupar um lugar de grande relevo na economia do país. Uma boa parcela dos artigos manufaturados do seu consumo era de produção interna, dispensando assim importações correspondentes de artigos estrangeiros. Este será um importante fator, de equilíbrio das nossas contas externas e da normalidade financeira do país. É nesta conjuntura, aliás, que repousará em grande parte a indústria: tornara-se um elemento indispensável ao funcionamento normal da economia brasileira que já não poderá mais dispensá-la sem um distúrbio profundo de todo seu equilíbrio. (p. 198)

Este contexto permite entrever com alguma nitidez as transformações socioeconômicas em curso por volta da segunda década do século XX, quando o Brasil já dispõe de um razoável parque industrial e, por conseguinte, de uma burguesia industrial, proletariado e classe média como forças políticas e sociais com capacidade de contestação aos interesses dominantes das oligarquias rurais, especialmente a cafeeira. Assim, é possível perceber que a nova configuração da sociedade brasileira fortaleceu uma ideia de valorização da educação não apenas como processo de formação cultural, mas também profissional, ou seja, a ampliação das camadas médias vislumbrou na educação um caminho para a ascensão social e a expansão industrial exigiu a preparação profissional de mão de obra.

Em consequência deste novo momento econômico-social diferentes educadores se reuniram em movimentos conhecidos como "entusiastas da educação" e "otimismo pedagógico"70, defendendo, em linhas gerais, a construção

\footnotetext{
${ }^{70}$ Nagle (1976) afirma que o primeiro grupo foi favorável a multiplicação dos estabelecimentos de ensino e a ampla incorporação de grande parcela da população ao processo de escolarização para que o país trilhasse o mesmo caminho de crescimento das maiores nações do mundo; e o segundo grupo argumentava em prol de novas formulações pedagógicas (escolanovismo) para promover a verdadeira formação do homem brasileiro.
} 
de um sistema nacional de educação, articulado desde o ensino primário até o superior, com o objetivo de impulsionar o progresso do país. A última reforma educacional da Primeira República, por sua vez, deu-se em meio a esta transição da sociedade e foi justamente esta nova realidade que suscitou expectativas em torno da escola, bem como pressionou o governo federal para que repensasse o ensino secundário, tanto com relação à organização e seu objetivo como também em relação à sua expansão quantitativa, ou como escreve Nagle (1976), era esperado que o governo federal desse "o grande passo para a transformação do ensino secundário brasileiro: de instituição seletiva e preparatória para os cursos superiores em instituição aberta a formação dos adolescentes" (p. 148).

A reforma de João Luís Alves teve como principais medidas a implantação definitiva do regime seriado, assumindo caráter universal na escolarização média brasileira; e a frequência obrigatória, além de ressaltar o papel fiscalizador e normatizador do governo federal em relação ao ensino secundário. Um dos atos mais marcantes desta postura centralizadora foi a imposição de que todos os estabelecimentos de ensino deveriam cumprir o regimento interno do Colégio Pedro II, no que diz respeito à organização didática e administrativa, ou seja, se tornou obrigatória a reprodução de um currículo para todos os estabelecimentos oficiais de ensino secundário no país e, não obstante, dos mesmos conteúdos programáticos oficialmente estabelecidos para o Colégio Pedro II.

\subsubsection{As contribuições de Manuel Said e Delgado de Carvalho}

No interior destas mudanças, a Geografia escolar também passou por alterações e Rocha (1996) nos fala do nítido florescimento uma educação voltada para a consolidação do nacionalismo-patriótico. Esta premissa é evidente no artigo $47 \S 6^{\circ}:$

No ensino da língua materna, da literatura, da geographia e da história nacionaes darão os professores themas para trabalhos escriptos assumptos relativos ao Brasil, para narrações, descripções e biographias dos grandes homens em todos os ramos de actividade selecionando, para os trabalhos oraes, entre as producções literárias de autores nacionaes, as que estiverem mais ao alcance ou mais possam interessar aos alumnos para desenvolver-lhes os sentimentos de patriotismo e civismo. [...] Serão excluídas, por seleção cuidadosa, as producções que, pelo 
estylo ou doutrinamento incidente, diminuam ou não despertem os sentimentos constitutivos dos caracteres bem formados. (apud ROCHA, 1996. p. 229)

O supracitado autor destaca que neste período houve a penetração da Geografia moderna nas salas de aula, sinalizando uma inquestionável transformação paradigmática da disciplina. Neste momento da pesquisa acreditamos ser interessante observarmos o material utilizado nas aulas de Geografia, com destaque para as propostas de mudança na abordagem da ciência geográfica, como o livro didático Compêndio de geografia elementar (1905), de Manuel Said Ali Ida (1861-1953). Nessa obra, de maneira inédita, o professor Manuel propõe estudar o Brasil por regiões argumentando que

Se atendermos às afinidades econômicas dos estados entre si e com elas conciliarmos, tanto quanto possível, as condições geográficas, teremos a seguinte divisão racional: • Brasil Central ou Ocidental, compreendendo as cabeceiras dos tributários amazônicos (e Tocantins-Araguaia): Mato Grosso e Goiás.

- Brasil Setentrional, ou Estados da Amazônia: Amazonas e Pará.

- Brasil de Nordeste. Zona a leste das duas precedentes limitada ao sul pelo rio S. Francisco (trecho inferior), e caracterizada pela falta de rios navegáveis, secas mais ou menos periódicas e pela produção de algodão, açúcar e gado no interior. Compreende: Maranhão, Piauí, Ceará, Rio Grande do Norte, Paraíba, Pernambuco e Alagoas.

- Brasil Oriental. Região dos estados produtores de café e fumo (além do açúcar) e situada a leste da linha que assinala a fronteira de Goiás (divisor d'águas entre o Tocantins e a bacia do $\mathrm{S}$. Francisco), e cujo prolongamento ao sul é o rio Paraná até a sua confluência com o Paranapanema. Compreende os Estados: Sergipe, Bahia, Espírito Santo, Minas Gerais, Rio de Janeiro e São Paulo.

- Brasil Meridional ou região produtora de mate, araucárias e cereais: Paraná, Santa Catarina e Rio Grande do Sul. (ALI, 1905, p. 136 apud VLACH, Edições Kindle, sem datação)

Vlach (sem datação) afirma que a proposta de Ali estava em contraposição ao padrão vigente até então, ou seja,

O estudo dos "Estados Unidos do Brasil", consoante seus estados-membros, geralmente dividindo-os em marítimos e interiores, configurando uma divisão meramente administrativa do Estado-nação brasileiro. Este procedimento empobrecia demasiado a descrição de seu vasto (e diferenciado) território. (sem paginação) 
Além deste mérito procedimental é preciso realçar como o trabalho do professor representou um marco na discussão teórico-metodológica, buscando estimular a Geografia científica no Brasil.

Outro caso de destaque que buscou redirecionar a Geografia escolar para os rumos da moderna concepção de Geografia é o do professor do Colégio Pedro II e mentor do novo currículo prescrito para a disciplina, Delgado de Carvalho (18841980). Este professor frequentou cursos superiores na área de letras e ciência política na França (em Lyon e Paris, respectivamente), direito na Suíça (em Lausanne) e economia e política na Grã-Bretanha (em Londres), no início do século XX, influências que o tornaram defensor do espírito progressista e da liberdade humana.

Em 1920 ele retornou definitivamente ao Brasil após contato com geógrafos ingleses e norte-americanos e ingressou por concurso no Colégio Pedro II para lecionar Inglês e, posteriormente, ministrou Geografia e Sociologia. No livro publicado em 1925, Methodologia do ensino de Geographico: introdução aos estudos de Geographia moderna, o professor parece ter como maior preocupação qual a direção que a disciplina de Geografia tomaria dentro do ensino secundário brasileiro. Deste modo, este livro propõe uma espécie de orientação direcionamento metodológica e, até mesmo, curricular para o ensino de Geografia no Brasil, de acordo com os princípios escolanovistas.

Por conseguinte, o livro funcionou como um manual para os professores ao propor "novos" métodos de ensino-aprendizagem, como a inversão de lócus de estudo, ou seja, Carvalho defende o estudo do local para o aluno, tornando o meio onde vive o aluno o objeto de estudo, espaço fundamental dos estudos. Somente depois de conhecido o espaço derredor, a professor deveria adicionar informações sobre outros lugares, procedimento que garantiria que a pátria como base para os estudos geográficos. Ele mesmo escreve neste sentido: "Devemos passar mais rapidamente sobre os assumptos que não têm aplicações no Brasil; deixemos o estudo mais detalhado das geleiras ao estudante suisso e o exame circumstanciado dos vulcões aos japonezes e aos equatorianos" (CARVALHO, 1925, p. 7). Outros aspectos importantes a serem mencionados é sua crítica ao fato da Geografia estar restrita no currículo do ensino secundário aos dois primeiros anos de ensino, alcançando apenas aqueles muito jovens e sem a maturidade necessária que os 
estudos geográficos precisam, como também a marca fortemente mnemônica da Geografia ensinada no Brasil, visto que os alunos eram apresentados a uma infinidade de dados e nomes a serem decorados a fim de que pelo menos alguns fossem guardados em suas memórias.

Em suma, podemos atestar que a importância que o professor Delgado de Carvalho atribuiu à Geografia escolar residiu na ideologia do nacionalismopatriótico, ou seja, a disciplina Geografia deveria fornecer os fundamentos lógicos para desenvolver um verdadeiro patriotismo, objetivo que seria mais facilmente alcançado com o edifício da Geografia moderna no Brasil. Em virtude deste posicionamento, Carvalho abominava a mera nomenclatura e defendia um estudo que partisse da Geografia física elementar, assim como entendeu que a antropogeografia merecia mais destaque nas aulas de Geografia humana, como já ocorria em boa parte dos países europeus (ROCHA, 1996). Seria motivo de espanto se as proposições do professor Carvalho não sofressem resistências, críticas e reações no meio escolar, afinal a Geografia escolar também consistia numa construção social e histórica. Todavia o próprio professor, já prevendo estes obstáculos, escreveu aquilo que acreditava serem os maiores óbices à implantação de uma orientação moderna para o ensino de Geografia, de acordo com o processo ocorrido na Inglaterra:

Um movimento análogo entre nós terá que luctar com as seguintes difficuldades: $1^{\circ}$ - A falta de vulgarização dos modelos e typos do novo curso geographico, cujo conhecimento é ainda restricto a meia dúzia de estudiosos. $2^{\circ}$ - A difficuldade de alcançar e reunir dos professores de geographia. $3^{\circ}$ - Caso seja possível alcançal-os, a difficuldade de convencel-os de que o que estiveram ensinando até hoje poucas relações tem com a verdadeira geographia. Um homem que conseguiu reter o nome de todas as sub prefeituras francezas e das províncias italianas, etc., e durante muitos annos tomou como guia o excellente mais archaico Cortambert, difficilmente se convencerá de que isto tudo nada tem com a geographia, e representa apenas a expressão geographica da administração pública. [...] Por conseguinte, para a implantação da nova geographia entre nós, não será sufficiente modificar o programma do estabelecimento typo; não será suficiente modificar o ensino em taes escolas que possuem bons professores de geographia que almejam a reforma. [...] Será necessario converter um a um, todos os mestres que já se incumbem de ensinar geographia a nossos jovens patrícios. (1925. p. 9 apud ROCHA, 1996. p. 236) 
Por fim para concluir esta breve, mas importante menção às tentativas de mudanças teóricas e práticas da disciplina Geografia, traremos uma última passagem do professor Carvalho de tom mais áspero e que ilustra bem seu incômodo com a manutenção do ensino tradicional durante tanto tempo. Assim, questiona:

Se em vez de torturar a memoria de um alumno e tornar-lhe assim odiosa a geographia com uma lista de nomes que nada tem a ver com a verdadeira geographia, o tempo empregado nisso tivesse sido consagrado a explicar no mappa a questão da borracha, suas phases principaes e sua posição actual, o mestre teria facilitado ao alumno o conhecimento de factos uteis, bem geográficos e de fácil lembrança (1925. p. 9 apud ROCHA, 1996. p. 236).

Todo esse esforço nos parece merecedor de uma ponderação. É bastante claro a perspectiva positivista presente tanto na proposta quanto na dura crítica elaborada por Delgado de Carvalho, cujo objetivo último parece consistir no recrudescimento do sentimento patriótico. O professor manifesta sua relutância em aceitar a continuidade do enfadonho ensino geográfico escolar sob a justificativa da excessiva memorização e da inexistente correlação entre o conteúdo e a vida do estudante. Pois bem, o esforço teórico-metodológico do professor são bastante condizentes com o contexto científico vivido no início do século XX e que, segundo nosso entendimento, sinalizam a consagração de uma concepção ontológica típica da ciência moderna, ou seja, a completa cisão entre o sujeito e o espaço. A disciplina Geografia, a partir das premissas arduamente defendidas por Delgado de Carvalho, estava prestes a conceber o espaço como mero objeto investigativo, do qual a previsibilidade e a repetição são processos inerentes. Ademais, persiste a ideia da disciplina como um enorme repositório de informações acerca do mundo, cabendo ao professor descortinar o que há de mais interessante ao longo de todo ecúmeno. Detentor da chave do "baú das informações" o professor de Geografia é a figura que tudo sabe sobre o mundo. Impossível não lembrar da situação que inicia este texto: as Repúblicas bálticas ainda estão em minha memória.

\subsubsection{O que houve com a Geografia escolar?}

O novo programa curricular de Geografia implementado na Reforma João Luís Alves, que teve grande suporte dos também professores de Geografia do 
Colégio Pedro II Fernando Raja Gabaglia e Honório Silvestre, foi bastante comemorado pelo professor Delgado de Carvalho por representar uma marcante orientação renovadora da Geografia.

Operacionalmente, entendemos ser interessante apresentarmos inicialmente o programa de Geografia para o ensino secundário e, em seguida, fazermos algumas ponderações. Naquele período a Geografia estava presente nos dois primeiros anos e no quinto ano. Assim estava organizado o currículo:

\section{PRIMEIRO ANO}

\section{PROLOGOMENOS (10 lições)}

A Geographia - Definicao e divisões. Sua utilidade.

A Terra - Forma, dimensões e movimentos.

O Systema solar - Planetas, satellites. A lua e suas phases. Dos systemas de Ptolomeu, Copérnico.

O Universo - Estrellas. As constellações; o Cruzeiro do Sul.

Orientação - Pontos Cardeaes. Rosa dos Ventos. A bussola.

Círculos da esphera terrestre - Coordenadas geographicas; a latitude e a longitude.

Obliquidade da eclíptica - Desigualdade dos dias e das noites. As estações.

Cartas Geographicas - Escalas. Unidades de extensão linear e de superfície.

\section{GEOGRAPHIA PHYSICA (6 lições)}

Nomenclatura geographica - Denominação das formas da Terra. Elementos solido, liquido, gazoso.

Os continentes e os mares - Typos de relevo. Relações entre relevo e as costas. Hidrographia: elementos de comparação. Classificação dos mares - Os Oceanos - As correntes oceânicas, sua disposição geral. - Mar de sargaço - Estudo sumario do Atlântico. - O Gulf Stream.

A Atmosphera - Noções sobre a temperatura, os ventos, as chuvas. Climas.

Os Continentes comparados entre si. - Analogias e contrastes, baseados na geographia physica. Recursos mineraes do globo. Flora. - Fauna.

\section{GEOGRAPHIA POLITICA (6 lições)}

Definições - O conceito da geographia humana, social, ou politica. A geographia economica.

Raças. - Línguas - Religiões - Classificação e distribuição geographica.

Formas sociaes. - Civilização: seus elementos, seus estágios evolucionários. - Instituições sociaes: o Estado, suas modalidades.

Os grupos humanos - Migrações: causas e resultados. - A colonização. - Formação das cidades.

Actividade economica - Criação - Agricultura - Indústria Transporte - Commercio - O "fator geographico". 
GEOGRAPHIA GERAL DOS CONTINENTES (18 lições)

Estudo ou descripção geral de cada continente na ordem seguinte: Posição, limites e dimensões - Aspecto geral do relevo e do litoral - Typos de climas - Hydrographia - Vegetação e animaes característicos - Populações - Divisão politica - Os recursos economicos.

\section{GEOGRAPHIA GERAL (40 lições)}

Estudo ou descripção geral de cada região, na ordem seguinte: Situação, limites, superfície. - Aspecto geral do relevo - Litoral - Clima - Hydrographia - Vegetação - População e principaes cidades - Governo - Recursos economicos.

REGIÕES NORTE-AMERICANAS

América do Norte (Regiões polares, Canadá, Estados Unidos). Indias Occidentaes (México, América Central, Antilhas).

REGIÕES SUL-AMERICANAS

Estados Septentrionaes (Colombia, Venezuela, as Guianas).

Estados do Pacífico (Equador, Perú, Bolívia, Chile).

Estados do Prata (Argentina, Uruguai, Paraguai).

REGIÕES DA EUROPA

Europa Occidental (Grã Bretanha, França, Belgica, Hollanda). Europa Meridional (Portugal, Espanha, Itália, os Balkans).

Europa Central (Allemanha, Austria, Suissa, Tchecoslovaquia, Hungria, Rumania).

Europa Occidental e Septentrional (Russia, Polonia, Estados Balticos, Finlandia, Suecia, Noruega, Dinamarca, Islandia).

REGIÕES DA ASIA

Asia Oriental (China e Japão).

Asia Meridional (Indo-China, Indostão e dependências).

Asia Occidental (Persia, Arabia, Turquia, Syria, Palestina).

Asia Septentrional (Siberia, e mais domínios da Russia).

Insulindia (Malasia, as Filippinas).

REGIÕES DA OCEANIA

Australasia (Australia e Tasmania, Nova Zelandia).

Terras Oceanicas (Melanesia e Micronesia)

REGIÕES DA AFRICA

Africa do Norte (Egypto e Sudão, Libia, Argelia e Tunisia, Marrocos).

Africa Occidental e Equatorial (regiões francezas, espanholas, inglesas, portuguezas e região belga; as ilhas oceanicas; Libéria).

Africa Oriental (Abissinia; regiões italianas, francezas, britânicas e portuguesas).

Africa do Sul (regiões portuguesas e britânicas). Ilhas africanas do Oceano Indico.

No "estudo" ou "descripção geral", o professor examinará os elementos geographicos geraes aplicados à região considerada. Além disso, em cada região, fará pelo menos um "estudo especial", examinando um aspecto interessante e próprio da região.

As aulas serão sempre dadas com o auxílio de cartas, e numerosos deverão ser os exercícios de leitura das mesmas e de esboço cartographicos e do mappa mudo, emprestando assim, ao ensino um cunho pratico. 


\section{SEGUNDO ANO}

\section{PARTE GERAL (40 lições)}

Situação geographica - Aspecto geral - Area e pontos extremos - A posição do Brasil no Continente Sul-Americano; dados comparativos.

Fronteiras Terrestres - Typos de fronteiras. Historico summario de sua formação. Linhas Convencionaes, demarcadas e a demarcar - Esboço geographico: Uruguai, a lagoa Mirim; Argentina, o território das "Missões"; Paraguay; Bolivia, o Acre; Perú, Colombia; Venezuela; as Guianas - os arbitramentos; a obra de Rio Branco.

Relevo - Aspecto geológico - Classificação por systemas orographicos - Massiço Atlantico (Serra do Mar, Serra Geral, Mantiqueira), Massiço Central (Systrma Goiano, Systema Mattogrossense) - Massiço Nortista - Massiço Guianense.

Estudo especial da Serra do Mar e da Mantiqueira - Formação, orientação, altitudes, gargantas e passos.

Planaltos e planícies - Relações geographicas e intercomunicações entre as bacias fluviaes.

Litoral - Morphologia: aspectos e relações geográficas com o relevo - Typos de costas - Mangues, recifes, barreiras, lagoas costeiras, dunas - Elevação do litoral; os sambaquis.

O Atlantico do Sul - Relevo - Correntes, marés - Ilhas Oceanicas.

Descripção do litoral - Litoral Septentrional: o archipelago amazônico - Litoral oriental: a Bahia - Litoral meridional: bahias de Guanabara, Paranagua: cabos e ilhas - A costa do Rio Grande do Sul.

Clima - Posição astronomica do Brasil - Latitude e altitude Distribuição das temperaturas, dos ventos e das chuvas - Typos de climas: super-humido, semi-arido e semi-humido; de planície e de altitude - Exemplos especiaes: Pará, Recife, Rio de Janeiro e São Paulo.

Salubridade e colonização - Importância dos serviços meteorologicos para a agricultura.

Hydrographia - Os grandes centros de dispersão de aguas Vertentes - Rios de planalte e de planície - Dados comparativos - Os lagos e regiões lacustres.

Bacias Hydrographicas: Amazonas, regimen, curso e delta - Rios temporários do Nordeste - Vertente oriental dos planaltos, estudo especial do São Francisco - O Parahiba e seus afluentes - Rios meridionaes.

Recursos naturaes - Mineração: ouro, ferro, manganez, carvão, pedras preciosas - Distribuição geographica.

Vegetação - Zonas principaes - Mattas e campos, caatingas, pantanaes.

Producções do reino animal.

População - Esboço ethnographico - Grupos indígenas antigos e actuaes - Linguas e religiões - O elemento europeu na população - Recenseamento do Brasil - Os grandes centros urbanos.

Os Estados: Limites, área, população e cidades principaes.

Divisão administrativa da Republica - O Governo - Instrucção publica - O Districto Federal. 
Economia Nacional - Condições geraes - As terras e a prosperidade - Agricultura, productos tropicaes: café, cacao, algodão, assucar - os cereais: milho, trigo, arroz - Zonas de produção - Criação de gado; frigoríficos - Indústrias extrativas: mineração, borracha, madeira, mate, carnaúba, castanha Industria Manufactureira - Fabricas do Brasil - Exposições.

Apparelhamento econômico - Viação, navegação e portos Telegrapho - Finanças - Os grandes troncos ferroviários

Commercio exterior - o seu desenvolvimento. Artigos de exportação.

\section{PARTE REGIONAL (40 lições)}

As regiões naturaes do Brasil - Divisão Regional do paiz - Bases geográficas racionais desta divisão - Distribuição dos Estados.

I - BRASIL SEPTENTRIONAL OU AMAZONICO (Estados do Pará, Amazonas, território do Acre).

Descripção geral: Posição, extensão, aspecto physico, hydrographia - Vegetação e recursos naturaes - Cidades principaes.

Descripção especial: o rio Amazonas como rede de viação e caminho de penetração - A pesca fluvial e recursos economicos da Amazonia - A questão da borracha - Os campos de criação Os portos de Manaos e Belém.

II - BRASIL NORTE-ORIENTAL (Estados do Maranhão, Piauhi, Ceara, Rio Grande do Norte, Parahiba, Pernambuco e Alagoas).

Descripção geral: Posição, extensão, aspecto physico, litoral - A zona semi-arida - Recursos naturaes - Cidade.

Descripção especial: O nordeste, primeira colonização, domínios estrangeiros, formação das unidades políticas - Zonas de criação e zonas agrícolas - A lucta contra as secas; grandes açudes - O Maranhão, como região de transição entre a Amazonia e o Nordeste - A emigração cearense - As salinas do Rio Grande do Norte - O porto de Recife.

III - BRASIL ORIENTAL (Estados de Sergipe, Bahia, Minas, Espirito Santo e Rio de Janeiro; o Districto Federal) Descripção geral: Posição, extensão, sub-regiões naturaes: litoral, serra e planalto - Climas - Rios - Os recursos economicos - Cidades.

Descripção especial: Bahia, a antiga metrópole e os bandeirantes bahianos - O caminha das minas - Historia do Rio de Janeiro Minas Geraes, província e Estado - Os períodos econômicos: período da mineração, período cafeeiro; a evolução actual para a polycultura - Os climas: typos de climas de montanhas, cidades de verão e cidades d'agua - A Bahia: café, cacao, couro, fumo, borracha - Minas: reservas de ferro, manganez e pedras: o gado - O porto do Rio de Janeiro - A Capital da Republica centro economico, social, politico e intellectual.

IV - BRASIL MERIDIONAL (Estados de São Paulo, Paraná, Santa Catharina, Rio Grande do Sul)

Descripção geral: Posição, extensão, sub-regiões naturaes: litoral, serra, planalto e planície rio-grandense. Climas, rios, recursos naturaes, população, cidades. 
Descripção especial: São Pau;p, centro histórico da colonização sul - Historia do Rio Grande do Sul - A terra roxa e o café: colonização, os Estado do Sul e a evolução para a polycultura A criação de gado e os frigoríficos - Industria manufactureira em São Paulo - As mattas do Paraná - O matte e os mercados sulamericanos - O Rio Grande: a região serrana, colonial e agrícola; a região da campanha - Rêdes ferroviarias do sul e portos Santos, empório mundial do café - Os mercados estrangeiros, a importação americana - A barra do Rio Grande - O Porto das Torres.

V - BRASIL CENTRAL (Estados de Matto Grosso e Goiaz) Descripção geral e especial: O relevo - A hydrographia - A penetração do interior; fundação de Goiaz - $\mathrm{O}$ acesso de Matto Grosso por via fluvial e por via férrea: a "Noroeste" - Principaes centros e recursos econômicos.

Durante o anno, o professor fará exercícios de esboços cartographicos e de mappa mudo.

A Descripção "especial" consta themas que servirão de assumpto às prelecções do professor, procurando este apontar os aspectos mais interessantes e próprios de cada região do Brasil.

\section{QUINTO ANO}

Introducção - Revisão das principaes noções de geographia astronômica elementar, já ministradas no curso de geographia $\left(1^{\circ}\right.$ anno) e indispensáveis para a comprehensão da matéria cujo estudo se vae iniciar.

Objectivo e definição da Astronomia e Cosmografia, suas divisões.

Céo, esphera celeste. Universo e mundo, Astros, sua classificação summaria.

Distancias angulares e diâmetro apparente.

Movimento diurno aparente dos astros, suas leis.

Pontos, linhas e circulos da esphera celeste.

Coordenadas astronômicas: horizonte, equatoriaes e eclípticas. Theodolito.

Luneta meridiana. Relogio Sideral.

Estrellas e constelações.

O Sol: constituição, movimentos.

Systemas planetarios, systema solar.

Leis de Kepler, Newton e Bode.

Estudo summario dos planetas e de seus satelites.

Cometas.

Estudo particular da Terra: forma, posição no espaço, dimensões.

Pontos, linhas, circulos e zonas da Terra.

Pontos do horizonte. Orientação. Bussola.

Coordenadas geographicas.

Principaes movimentos da Terra.

Consequencia dos movimentos da Terra e da inclinação do eixo.

Meteoros cosmicos.

Lua: Forma, constituição, movimentos, phases.

Eclipses, occultações, passagens.

Marés.

Medida de tempo. Calendários. Cómputo ecclesiastico. 
Methodos de observação astronomica. Revisão dos principaes instrumentos.

Observatorios, annuarios, ephemerides.

Correcções na observação astronomica: depressão, refracção, parallaxe, semi-diametro.

Cartas e globos terrestres e cellestes. Projecções e desenvolvimento.

Problemas fundamentaes da astronomia: indicação dos methodos para a determinação das coordenadas terrestres de um logar, da posição dos astros e da hora.

Noções da historia da Astronomia.

Principaes hypoteses cosmogonicas.

Ao observarmos este programa, vemos que o $1^{\circ}$ ano continuou voltado aos estudos astronômicos, mantendo a tradição herdada da Geografia clássica e reforçada pelo positivismo de Comte. O amplo espaço conferido aos estudos astronômicos parece um esforço de "matematizar" a disciplina, atribuindo, por conseguinte, maior cientificidade ao currículo geográfico escolar pelo estudo da forma da Terra, movimentos do planeta etc. A "positividade" científica daquele período buscou posicionar as ciências humanas em função das matemáticas, "matematizando" tudo o que for possível e supondo que o restante ainda não recebeu o devido tratamento científico moderno.

A fisiografia é o tema predominante da segunda parte do programa do $1^{\mathrm{o}}$ ano, tema considerado basilar para uma verdadeira análise geográfica (ROCHA, 1996). Seguindo o método cartesiano, a fisiografia "permitiria um conhecimento científico das causas dos fenômenos, bem como sua classificação" (idem. p. 242), conduta bastante distinta da nomenclatura estéril praticada até então.

$\mathrm{Na}$ terceira parte do programa de $1^{\mathrm{o}}$ ano há destaque para a antropogeografia ratzeliana, cabendo aos professores dedicarem ênfase ao homem, considerado o verdadeiro objeto geográfico da moderna Geografia nascente. A filosofia moderna, como já explanado anteriormente, inverte a noção de sujeito - relacionado à submissão - para a de sustentação, ou seja, aquele que é próprio construtor de sua subjetividade, que se constrói por ele mesmo na existência. A subjetividade consiste em atributo de autonomia do homem e, em tempos de modernidade, a autonomia do sujeito significa autonomia do sujeito da razão. Por seu turno, o procedimento científico cartesiano impõe a todos fenômenos, processos, matérias, crenças o exame da dúvida minuciosa, restando como única certeza a ideia de que sua própria existência é enquanto ser pensante. Portanto, com bastante nitidez, é possível 
percebermos que o ensino de Geografia, implementado a partir da Reforma João Luís Alves, buscou reproduzir nas salas de aula a ideia vigente de homem racional como protagonista da realidade.

A quarta parte do programa esteve voltada pela "geografia geral" a partir da fisiografia e em seguida pela antropogeografia, tendo como contexto a divisão regional do país. Aquela organização regional foi sustentada por diferenças naturais e a nomenclatura de cada região foi dada pelo critério de localização cardeal em função da posição geografia, sugerindo a introdução do conceito de "região natural", tão importante para a Geografia moderna (ROCHA, 1996). Evidencia-se o objetivo de reforçar o sentimento patriótico e que Vlach (sem datação) assim contextualiza:

\begin{abstract}
A ideologia do nacionalismo patriótico nos remete ao contexto político da época que, em poucas palavras, pode ser caracterizada por um processo inadiável: a formação da nação brasileira. Se a irrupção do Brasil como Estado independente em 1822 já havia colocado a formação da nação como a questão, por excelência, da arena política brasileira, o fato é que quase não se havia avançado nesse sentido. Assim, essa questão foi apontada por líderes políticos e intelectuais como essencial no período que, grosso modo, estende-se da Proclamação da República (1889) até meados da década de 1950. (Edições Kindle, sem paginação)
\end{abstract}

A organização curricular, por sua vez, evidencia a priorização de uma fundamentação ontológica através da subjetividade do sujeito (racional) que conhece e constrói ideias distintas e claras. Destarte, o currículo escolar de Geografia (moderna) efetivou, segundo nosso entendimento, o pensamento cartesiano nas salas de aula, indicando um profundo processo de separação na tradição ocidental e revelado em diferentes dimensões, como na questão religiosa através da separação entre Deus (o sagrado), o homem (humano) e a natureza e, com especial destaque em nosso caso, representando a ruptura ontológica entre corpo e mente, entre a razão e o mundo, enfim, entre o sujeito e o espaço.

É a partir desta estrutura curricular que se baseiam as separações mais radicais, fundamentais para um conhecimento "descorporizado" e "descontextualizado", permitindo um conhecimento que se pretende objetivo e universal. A radical ruptura apresentada por Descartes, e esboçada no currículo escolar de Geografia, consiste, em suma, em colocar em mundos opostos o sujeito pensante e o mundo exterior pensado, incluindo o próprio corpo e todas as formas 
objetivas de envolvimento com o mundo. Portanto, o corpo figura como mais um objeto exterior, distinto do sujeito pensante que observa e organiza racionalmente todo o ecúmeno.

\subsection{Algumas considerações sobre a educação no período Varguista}

No décimo mês de 1930 o governo do presidente Washington Luís foi derrubado por um movimento armado iniciado no sul do país. Esse movimento foi um indicativo do descontentamento de uma parcela da sociedade com relação ao problema de desenvolvimento, crise que já se avizinhava e que foi acentuada ao final da década de 1920. O processo de modernização econômica iniciado em décadas anteriores alcançou elevado estágio em meados década de 1930, todavia a grave crise capitalista de $1929^{71}$ redefiniu a divisão internacional do trabalho, o que estimulou uma "aceleração" no surgimento de indústrias em países que até então estavam restritos ao fornecimento de matérias-primas e gêneros alimentícios. Exemplo desta situação, o Brasil conheceu um forte abalo nas exportações de café, principal produto comercial, acarretando um redirecionamento da renda aplicada no setor agrícola para a promissora atividade industrial.

Ao analisarmos com maior cuidado este período, podemos ver que o recrudescimento da atividade industrial simboliza a afirmação da passagem para formas de produção baseadas na fábrica, na mecanização, na expansão da grande indústria. Recorremos ao pensamento de Ianni (1975) que ensina sobre a inadequação do padrão exportador para atender às exigências crescentes da economia e da sociedade. Neste sentido, emergiu o modelo de "substituição de importações", que

[...] Envolve a reformulação dos vínculos externos e com a sociedade tradicional. Com base na política de massas e no dirigismo estatal, estabelece gradações nas rupturas estruturais indispensáveis à sua execução. Fundamenta a política externa

\footnotetext{
${ }^{71}$ Para sermos mais precisos com os fatos é fundamental mencionarmos, ainda que sumariamente, os efeitos práticos da crise econômica de 1929 no Brasil, que, efetivamente, desencadeou uma grave crise. $\mathrm{O}$ valor dos produtos básicos da economia brasileira (em particular o café), cai brusca e consideravelmente, assim como as exportações sofrem grande redução. Tudo isto determinará naturalmente um brusco e profundo desequilíbrio das contas externas do país e um déficit considerável. (PRADO JR. ????)
} 
independente e implica numa doutrina do Brasil como potência autônoma. (p. 54)

Em função dessa mudança, a chegada na década de 1930 registra algumas mudanças de relevo no cenário político-econômico nacional, que, evidentemente, estão em estreita correlação com o sistema educacional brasileiro e com a disciplina escolar Geografia. Podemos considerar, ainda segundo Ianni (1975), que até 1945 o Brasil conviveu com acontecimentos políticos vinculados à necessidade de redução do poder político e econômico dos setores agroexportadores e importadores, com especial destaque do setor cafeeiro. Destarte, os tradicionais interesses latifundiários começaram a ser fortemente pressionados pelas recentes demandas da burguesia urbana-industrial, que procurava se apoderar das estruturas estatais. Este cenário político representava os descontentamentos de vários setores da classe média, especialmente na ala mais jovem das forças armadas, o conhecido tenentismo, grupo que tomava cada vez mais consciência de sua marginalização política, bem como de outros grupos.

As elites do país assistiam, dia após dia, a deterioração de suas bases de sustentação e o Governo gradativamente perdia legitimidade e autoridade. Nesse clima de intensa agitação política ocorreram eleições para a Presidência da República, que colocadas sob suspeitas de fraude atestaram a vitória do candidato da situação, o paulista Júlio Prestes. Sua vitória somada ao assassinato de João Pessoa, candidato derrotado à vice-presidência na chapa de Getúlio Vargas, foram suficientes para a irrupção de um movimento armado.

Esse conturbado momento resultou na chamada "Revolução de 1930" e na ascensão de Getúlio Vargas ao poder até 1945. Ainda segundo o supracitado autor,

Estabelece-se o conflito entre as oligarquias tradicionais e os setores urbanos nascentes, tais como a classe média, a burocracia civil e militar, os incipientes grupos de empresários industriais e o proletariado nascente. Por outro lado, as lutas políticas estão relacionadas com o confronto entre os diferentes projetos de modernização, democratização e desenvolvimento econômico. $\mathrm{Na}$ base desses confrontos, estão, no entanto, as contradições entre a economia agrário-exportadora e a economia industrial em formação. Esses confrontos são o fulcro dos acontecimentos até 1945. (p. 16)

Nesse contexto, não há um claro rompimento com a velha estrutura de poder, sendo mais palpável uma gradual transição entre o Brasil agrário ao Brasil 
industrial emergente. É em meio a esse período transicional, nos primeiros anos do Governo Provisório, que ocorre a cisão entre tenentistas e constitucionalistas. A Revolução Constitucionalista de 1932 foi um movimento em prol da Constituição, mas revelou não apenas a contrariedade com relação a tendência centralizadora do Governo, que retirava a autonomia dos Estados, como também evidenciou a ação de latifundiários e de liberais. A promulgação da Constituição de 1934 negligenciou os interesses das elites tradicionais, mas, por outro lado, arrefeceu os movimentos mais dedicados às mudanças radicais da sociedade e pavimentou o caminho de aproximação com os velhos interesses.

Por conseguinte, naquele período houve diversas divergências ideológicas entre os defensores de diferentes projetos para a sociedade brasileira e, por óbvio, a educação não passou incólume por todo esse turbilhão de transformações. De maneira bem sucinta podemos afirmar que a relação entre desenvolvimento econômico e educação se tornou bastante evidente, destacadamente num período de intensificação da atividade industrial e da urbanização. A educação escolar passou a ser uma reivindicação cada vez maior na sociedade, quando se observa uma grande complexificação das questões culturais, econômicas e políticas, como fica explícito numa sociedade que mantém por séculos uma contradição fundamental entre as classes sociais que sempre detiveram o poder e as classes subalternizadas, perenizando a educação como privilégio da minoria hegemônica (ZOTTI, 2004).

Romanelli (1986) ao analisar esse período sintetiza de forma bastante precisa todo aquele contexto ao escrever que
A Revolução de 30, resultado de uma crise que vinha de longe destruindo o monopólio do poder pelas velhas oligarquias, favorecendo a criação de algumas condições básicas para a implantação definitiva do capitalismo industrial no Brasil, acabou, portanto, criando também condições para que se modificassem o horizonte cultural e o nível de aspirações por parte da população brasileira, sobretudo nas áreas atingidas pela industrialização. (p. 60)

Nos primeiros anos da década de 1930 instaurou-se um amplo e profícuo debate político e educacional, envolvendo católicos, liberais e governistas acerca dos próximos destinos da educação. Zotti (2004) apresenta o debate mais profundo entre católicos e liberais, cuja oposição consistia em, de um lado, os primeiros 
argumentando em favor de um ensino "alicerçado na pedagogia tradicional, nitidamente elitista, defendendo a manutenção da ordem econômica e política vigente na Primeira República" e, de outro lado, os liberais que apregoavam a "pedagogia da Escola Nova e a construção de um país em novas bases econômicas e políticas, de acordo com o modelo urbano-industrial" (p. 88, grifos nossos). Em suma, é possível considerar que esse debate se concentrou em torno de três aspectos centrais: a laicidade, a defesa da escola pública obrigatória e gratuita e a coeducação dos sexos como direito de igualdade.

Romanelli (1986) assegura que a Igreja Católica temeu perder o monopólio do ensino médio, privilégio da elite que pagava para estudar, e se sentiu ameaçada pela ascensão social burguesa que defendia uma educação para atender às necessidades impostas pelo desenvolvimento urbano-industrial. Nesse contexto contestatório,

\begin{abstract}
As classes médias em ascensão reivindicavam o ensino médio, e as camadas populares, o ensino primário. Daí por que o movimento renovador compreendeu que havia chegado a hora de o Estado assumir o controle da educação e que, portanto, esta deveria ser gratuita e obrigatória, dada as necessidades da nova ordem econômica em implantação. (p. 143)
\end{abstract}

No centro desse debate estava o Governo, que fingia neutralidade e disposição para dialogar com todos os grupos interessados. O novo governo instituiu o Ministério da Educação e Saúde Pública sob a liderança de Francisco Campos. O Ministro foi precursor o sistema nacional de educação, dando fim ao longo período de sistemas estaduais desarticulados, como também organizou o ensino secundário, que deixou de ser apenas um conjunto de cursos preparatórios propedêuticos. As medidas adotadas por Francisco Campos, ainda em 1931, foram as primeiras que proporcionaram uma estrutura orgânica ao ensino secundário, como também assinalam o ineditismo de uma proposta de alcance a todo o território nacional. De forma complementar, o decreto $\mathrm{n}^{\mathrm{o}}$ 21.241, de 1932, extinguiu definitivamente os cursos de exames preparatórios e impôs a adoção de curso secundário de currículo seriado, com frequência obrigatória, em todo o país. Outro aspecto bastante relevante foi a estruturação do ensino secundário em dois ciclos, o 
fundamental (oferecido em cinco anos) e o complementar ${ }^{72}$, cuja habilitação em ambos se tornou condição mínima para ingresso nos cursos superiores (ROCHA, 1996).

O ciclo fundamental procurou garantir a todos os estudantes uma educação com caráter de formação geral e assim ficou organizado, segundo o artigo $3^{\circ 73}$ :

Art. $3^{\circ}$. Constituirão o curso fundamental as materias abaixo indicadas, distribuidas em cinco annos, de accôrdo com a seguinte seriação:

$1^{\circ}$ serie: Portuguez - Francez - Historia da civilização Geographia - Mathematica - Sciencias physucas e naturaes Desenho - Musica (canto orpheonico).

$2^{\circ}$ serie: Portuguez - Francez - Inglez - Historia da civilização - Geographia - Mathematica - Sciencias physicas e matuares Desenho - Musica (canto orpheonico).

$3^{\circ}$ serie: Portuguez - Francez - Inglez - Historia da civilização - Geographia - Mathematica - Phyica - Chimica - Historia natural

- Desenho - Musica (canto orpheonico).

$4^{\circ}$ serie: Portuguez - Francez - Latim - Allemão (facultativo) - Historia da civilização - Geographia - Mathematica - Physica Chimica - Historia natural - Desenho.

$5^{\circ}$ serie: Portuguez - Latim - Allemão (facultativo) - Historia da civilização - Geographia - Mathematica - Physica - Chimica Historia natural - Desenho.

É de se ressaltar o importante papel realizado pelo movimento escolanovista no interior deste período de profunda transformação da educação escolar brasileira. Ainda em 1932 foi lançado o Manifesto dos Pioneiros da Educação Nova, onde são reafirmadas todas as propostas de renovação já apresentadas, com o claro objetivo de influenciar as decisões do governo e provocar "o aprofundamento dos debates, que tiveram continuidade e foram fundamentais, especialmente por ocasião da

\footnotetext{
${ }^{72}$ Segundo o artigo $4^{\circ}$ da Lei Francisco Campos (Decreto ${ }^{\circ} 19.890$, de 18 de abril de 1931) o ciclo complementar teve dois anos de duração e foi necessário apenas para os interessados em ingressarem em alguns cursos superiores (Direito, Medicina, Odontologia, Farmácia, Engenharia e Arquitetura), estabelecendo disciplinas obrigatórias segundo o curso pretendido. Por exemplo, para os candidatos ao curso de direito o artigo $5^{\circ}$ definia:

Art. $5^{\circ}$. Pará os candidatos á matricula no curso juridico são disciplinas obrigatorias:

$1^{o}$ serie: Latim - Litteratura - Historia da civilização - Noções de Economia e Estatistica - Biologia geral - Psychologia e Logica.

$2^{\circ}$ serie: Latim - Litteratura - Geographia - Hygiene - Sociologia - Historia da Philosophia.

Já para os cursos de Medicina, Odontologia e Farmácia o artigo $6^{\circ}$ previa:

Art. $6^{\circ}$. Para os candidatos á matricula nos cursos de medicina, pharmacia e odontologia são disciplinas obrigatorias:

$1^{o}$ serie: Allemão ou Inglez - Mathematica - physica - Chimica - Historia natural - Psychologia e Logica.

$2^{\circ}$ serie: Allemão ou Inglez - Physica - Chimica - Historia natural - Sociologia.

${ }^{73}$ Disponível em: https://www2.camara.leg.br/legin/fed/decret/1930-1939/decreto-19890-18-abril1931-504631-publicacaooriginal-141245-pe.html Acessado em: 18/09/2021
} 
elaboração dos projetos das Constituições de 1934 e 1937" (ZOTTI, 2004. p. 90). Indubitavelmente, Francisco Campos sofreu influência do escolanovismo na formulação de sua política escolar nacional, visto que procurou desenvolver um processo educativo concentrado na "aquisição de conhecimento e não apenas na quantidade de noções e conceitos que são transmitidos pelos professores" (ROCHA, 1996. p. 259). Destarte, a educação deveria ser útil aos estudantes para a construção “[...] um vigoroso sistema de hábitos e de tipos definidos e precisos de reação, de modo que as situações novas que lhe crear a vida possam ser rápida e seguramente elaboradas no sentido de soluções concretas e adequadas" (Exposição de motivos da reforma do ensino secundário Apud ROCHA, 1996. p. 259).

Todavia, ainda que o movimento renovador escolanovista tenha influenciado as políticas educacionais, é preciso sublinhar que tal influência se deu numa perspectiva burguesa, ou seja, os propósitos do movimento consistiam, em última instância, na adequação do sistema educacional à nova ordem econômica e política sem qualquer questionamento a estrutura da sociedade capitalista que se consolidava. Como assinalamos anteriormente, aquele período foi marcado por um acordo tácito entre o novo e o velho, ou seja, não houve uma ruptura radical na sociedade, mas um rearranjo que comportou velhas e novas lideranças. Nesse sentido, o movimento escolanovista

\footnotetext{
Estava a favor da ordem que então se implantava e não a questionava. Mas estava também consciente da defasagem existente entre a nova situação econômica e social e a escola tradicional. A sua luta era contra a escola tradicional, não contra o Estado burguês. Representava o pensamento das lideranças jovens na composição das estruturas de poder da época, estruturas que, como já afirmamos, contavam também com as velhas lideranças. (ROMANELLI, 1986. p. 151)
}

Por conseguinte, o mesmo movimento transformador atingiu o ensino de Geografia escolar, tema que nos dedicaremos a partir de agora. Uma consistente argumentação inicial é encontrada nas "Orientações metodológicas para a utilização dos novos programas das disciplinas, de acordo com o Decreto $\mathrm{n}^{0}$ 21.241", documento que apresenta as seguintes considerações sobre o ensino de Geografia:

O ensino da Geografia, unidos ao das Ciências Físicas e Naturaes tem por objetivo o conhecimento do meio ambiente de que dependem as sociedades humanas. Compete-lhe, assim, dar a conhecer, a princípio, a estrutura física da Terra, o relêvo do solo, 
o litoral, o clima, a hidrografia, os recursos naturaes. Cuidará, depois, em correlação com o ensino da História, de apreciar a repartição dos homens, as raças, as línguas, as religiões, os costumes, a organização econômica e política. Estudará as relações do homem com a Terra, os produtos naturaes, a agricultura, a indústria, as vias de comunicação e o comércio. Em conexão com a astronomia e Física, tratará da posição da Terra no Universo. Utilizar-se-á sempre dos mapas como os mais importantes dos seus meios de expressão. Terá sempre em vista ministrar ao aluno o conhecimento dos recursos e das necessidades do Brasil [...]. Concorrendo com o estudo da História, deve a Geografia ter também como objeto a educação política, para a qual contribuirá primeiro, com o estudo das condições geográficas da formação do Estado e com a demonstração de que êste, nascido como qualquer sociedade coletiva, se caracteriza, geograficamente, pela soberania territorial e requer, para se manter íntegro, a fixação do grupo social ao solo. (apud ROCHA, 1996. p. 260)

Em outra passagem, o mesmo documento assinala a importância de efetivação de uma mudança na metodologia de ensino-aprendizagem, demonstrando claramente a influência do movimento escolanovista. Segundo as Orientações no ensino de Geografia

$$
\begin{aligned}
& \text { Convém, nas duas primeiras séries, aplicar-se } \\
& \text { preponderantemente o método intuitivo, por meio de } \\
& \text { demonstrações de experiências. Tirando partido das atividades } \\
& \text { manuaes expontâneas dos alunos, deve o professor fazer com que } \\
& \text { se organizem na aula modelos em cartão, madeira ou massa } \\
& \text { plástica. A leitura das cartas começará por familiarizar o } \\
& \text { estudante com a representação dos acidentes geográficos } \\
& \text { próprios de regiões bem conhecidas. Desde os primeiros passos } \\
& \text { na leitura de cartas, é de maior vantagem que o aluno perceba a } \\
& \text { valiosa significação do Atlas para o conhecimento sólido da } \\
& \text { Geografia [...]. (Idem. Ibidem) }
\end{aligned}
$$

Os excertos acima oferecem uma boa noção acerca da dimensão da Geografia escolar em um período de renovação da educação brasileira. É interessante percebermos com a disciplina fora colocada em estreita correlação com outras ciências, fato que ilumina uma possível imprecisão de seu verdadeiro objeto de estudo, cabendo, por conseguinte, tudo o que estivesse fisicamente disposto no mundo, desde as rochas que compõem a estrutura física do planeta até os astros celestes, passando pela sociedade. Constata-se também uma mudança importante relacionada ao método, que buscava abandonar as angustiantes aulas expositivas e mnemônicas através da recomendação de contato direto com a natureza para apurar a observação da realidade objetiva. No entanto, permaneceu inalterado o papel de 
"baú do conhecimento", ou seja, a disciplina era tomada como um grande repositório de temas apresentados aos estudantes que deveriam apreendê-los na maior quantidade possível para simplesmente ampliar seu cabedal de conhecimentos. Portanto, estudar Geografia significava absorver informações que seriam utilizadas em exames, mas que não mobilizavam nenhum desejo de transformação ou de mudança porque o espaço era uma mera realidade a ser observada, compreendida e aceita.

Para avançarmos em nossa investigação, vejamos a distribuição dos conteúdos estabelecida por Francisco Campos:

\section{Primeira Série - três horas semanais}

I - Prolegômenos: Sistema Solar, a Terra no Espaço, a lua, constelações, coordenadas, fusos, estações etc.

II - Geografia Física: Estrutura da Terra, distribuição das terras emersas e mares. O elemento sólido, elementos líquidos, elementos gazozos. Litorais e tipos de costas, dunas, relações. A vida animal e vegetal sobre o globo.

III - Práticas de Geografia: Demonstração e experiências com o telúrio e o pêndulo de Foucault. Processos de orientação, determinação de latitude, longitude, hora legal, escalas. Leitura de cartas.

\section{Segunda Série -2 horas semanais}

I - Geografia Geral dos Continentes: posição, limites, dimensões comparadas, relevo, climas etc. Descrição sumária de cada continente com as divisões naturaes.

II - Geografia Física do Brasil: situação, aspectos, dimensões, fronteiras, relevo, classificação dos sistemas e maciços, litoral, clima etc.

III - Práticas de Geografia: experiências sobre formas do relevo, formação de chuvas e demonstração de ação das águas sobre o modelado.

\section{Terceira Série - 2 horas semanais}

I - Geografia Política e econômica: populações e raças, línguas e religiões, migrações e civilização, formação de cidades. As capitais, a Circulação e transportes. Cultivos agrícolas alimentícios e industriaes. Criação de animais e exploração mineral. Utilização de fôrças naturaes.

II - Geografia Política e Econômica do Brasil: Populações, grupos étnicos, elemento europeu, colonização, recenceamento. Recursos naturaes e mananciais de energia. Condições gerais de agricultura, o gado, indústria extrativa. Transporte e Comércio.

\section{Quarta Série - 2 horas semanais}

I - Geografia dos principaes países: estudo espacial de cada uma das seguintes potências, nas suas feições físicas e políticas particulares, salientando os principaes problemas sociais ou econômicos: Inglaterra e o Império Britânico, a Alemanha e a Europa Central, França e colônias, Itália e Adriático, Península 
Ibérica, Repúblicas Russas, Japão, China, Estados Unidos e Argentina.

II - Geografia Regional do Brasil: Descrição física e política de cada uma das regiões naturaes do país. Estudo dos principaes problemas sociaes e econômicos da atualidade e da evolução econômica das regiões naturaes: Brasil setentrional, Brasil Norte-Oriental, Brasil Oriental, Brasil Meridional, Brasil Central.

\section{Quinta série - 2 horas semanais}

I - Elementos de Cosmografia: Sistema Solar, planeta, cometas etc.

II- Meteorologia e climas: Atmosfera, composição, ventos, temperatura do ar, médias térmicas, umidade, precipitações, climas da Terra, classificações dos principaes tipos. Climas do Brasil.

III - O elemento sólido: a crosta terrestre, relevo do solo, erosão e tectônica, erosão fluvial e seu ciclo, formação de vales, tipos de planaltos e planícies, influências das rochas sobre a topografia. Relêvo vulcânico, desértico, costas e recifes.

IV - O elemento líquido: Oceanos e mares, relevo submarino, água do mar, salinidade, correntes, vagas, ressacas. Lagos, águas correntes, escoamento fluvial, ciclo vital dos rios, tipos de regimes. Estudo de rios brasileiros.

$\mathrm{V}$ - Elementos de Biogeografia: Influência do meio sobre a distribuição da vida do Globo: as plantas, animais e Homem. Distribuição e tipos de vegetais. Distribuição dos animais, fauna terrestre e condições de vida do Homem nos diferentes meios.

VI - Geografia Comparada da América: Estrutura, relêvo, litorais, vegetais, recursos naturais, zonas fisiográficas, etnografia etc. (Apud ROCHA, 1996. P. 262/263)

A despeito de todo o movimento renovador, ainda foi possível perceber permanências daquele ensino praticado anteriormente. A dificuldade para uma transformação efetiva em sala de aula pode ser creditada à inexistência de um corpo docente plenamente consciente dos objetivos do ensino secundário e do papel que se esperava da disciplina, reduzindo as aulas a uma simples reprodução de conteúdos através de aulas expositivas. Acerca desta questão cabe frisar que a Geografia não havia se institucionalizado no ensino superior do Brasil até a década de 1930. O primeiro curso universitário de Geografia do país foi criado em 1934 na Universidade de São Paulo, sob responsabilidade francesa do Prof. Pierre Deffontaines, que veio especialmente da França para ocupá-la, compondo a Faculdade de Filosofia, Letras e Ciências Humanas. Em 1935, a cátedra passou para a responsabilidade do Prof. Pierre Monbeig. Data também de 1935 a criação, no Rio de Janeiro, da Universidade do Distrito Federal, transformada em 1938 em Universidade do Brasil, que contava com a Faculdade de Filosofia, Ciências e 
Letras. Essa Faculdade buscou desenvolver a cultura filosófica e científica, bem como a formação de professores secundários, que até então eram oriundos de outras profissões, como advogados (ROCHA, 1996).

Para não perdermos de vista nossos objetivos é preciso marginalizar um pouco essa questão e observar que o currículo prescrevia um professor detentor de informações, capaz de reproduzi-las da forma mais eficiente possível para que o máximo de estudantes pudessem absorvê-las, tendo em vista que boa parte daquelas informações seriam esquecidas após os exames. De forma ainda mais incisiva, podemos considerar que a disciplina escolar Geografia abordava o espaço como vasto quadro a ser observado e apreendido naqueles traços que mais se destacavam aos olhos. Destarte, o observador consolidava em sua formação a ideia de que o espaço é um dado, um produto acabado e que sua construção já havia concluída, tanto pela ação da natureza quanto pelas diferentes sociedades ao redor do mundo. Por conseguinte, nas salas de aula o espaço é tratado pela ciência moderna a partir do prisma da objetividade, ou seja, reinam nas aulas de Geografia a impessoalidade e uma pretensa isenção na análise dos fenômenos e dos objetos, procedimento que garante um sujeito "desterritorializado".

Pois bem, após a explanação deste período é preciso avançar em nossa análise e um momento de grande destaque é o estabelecimento da Ditadura do Estado Novo, em 1937. Vargas deixou bastante claro em visita à Porto Alegre o caráter pretendido para a educação no país a partir de então:

Eu vos direi agora que para a consolidação desta obra, precisamos contar com a educação da juventude e com a mocidade que surge das escolas primárias e elementares, dos ginásios e escolas superiores. E, para isto, todos precisam ser educados dentro da doutrina do Estado Novo. Desapareceu e tem de desaparecer a exterioridade do livre didatismo. Agora precisa ser estabelecida a doutrina do Estado. (HORTA, 1994 apud ROCHA, 1996. p. 273)

Centralização e uniformização impregnam as orientações educacionais nacionais e, como podemos perceber, a partir daquele ano as lutas ideológicas mergulham num momento de "hibernação" em função da limitação à circulação de ideias contestatórias. O Estado assumiu um ideário mais conservador e passa a desempenhar, com relação à educação, uma ação de caráter supletiva, como é percebido no artigo no 129 da Constituição Federal de 1937: 
A infância e à juventude, a que faltarem os recursos necessários à educação em instituições particulares, é dever da Nação, dos Estados e dos Municípios assegurar, pela fundação de instituições públicas de ensino em todos os seus graus, a possibilidade de receber uma educação adequada às suas faculdades, aptidões e tendências vocacionais ${ }^{74}$.

Outro aspecto importante a ser salientado acerca da Constituição de 1937 é a sua explícita dualidade educacional, ou seja, "os ricos proveriam seus estudos como melhor convinha, no sistema público ou particular, com objetivo propedêutico. Os pobres deveriam destinar-se às escolas profissionalizantes" (ZOTTI, 2004. p. 93). Esse aspecto dual além de revelar o ideário político do Estado acerca da educação, evidencia também como o Estado utiliza o aparato pedagógico como instrumento para a manutenção da sociedade tal qual se apresenta. Neste sentido, acreditamos estar observando a crítica gramsciana da escola classista/dualista, ou melhor, a dualidade da função escolar como instrumento de manutenção da estrutura social hegemônica, ou seja, a classe dominante organiza e mantém seu controle ideológico sobre as classes subalternizadas através do domínio intelectual e moral. O filósofo ao analisar a situação italiana, de modo bastante semelhante ao que entendemos ocorrer no Brasil, escreve que

\begin{abstract}
A escola tradicional era oligárquica, já que destinada à nova geração dos grupos dirigentes, destinada por sua vez a tornar-se dirigente: mas não era oligárquica pelo seu modo de ensino. Não é a aquisição de capacidades de direção, não é a tendência a formar homens superiores que dá a marca social de um tipo de escola. A marca social é dada pelo fato de que cada grupo social tem um tipo de escola próprio, destinado a perpetuar nestes estratos uma determinada função tradicional, dirigente ou instrumental. (2016. p. 45)
\end{abstract}

Coerente a esta ideia e atendendo ao desenvolvimento industrial em curso foram criadas em quase todos os estados do país as escolas técnicas profissionalizantes, que consistiram não apenas em formadoras de mão de obra para o setor industrial, mas também um aparelho de reprodução da divisão social do trabalho e da ideologia dominante, consolidando a estrutura de classes.

No que concerne mais especificamente à disciplina escolar Geografia o período do Estado Novo também é de grande relevância, especialmente quando

\footnotetext{
${ }^{74}$ Disponível em: http://www.planalto.gov.br/ccivil_03/constituicao/constituicao37.htm Acessado em: 18/09/2021
} 
abordamos a questão do nacionalismo-patriótico. Nagle (1976) ensina que esse sentimento que procurou ser explorado ainda na década de 1920, quando

As primeiras manifestações nacionalistas apareceram, de maneira mais sistemática e mais influenciadora, no campo da educação escolar, com a ampla divulgação de livros didáticos de conteúdo moral e cívico ou, melhor, de acentuada nota patriótica. São obras que pretendem fornecer à criança e ao adolescente uma imagem do País adquirida por via sentimental; [...] ocorre que a doutrinação iniciada no campo da educação escolar repercutiu, na época, muito mais do que quaisquer outras, além do que teve maior continuidade. (p. 44)

As palavras do então Ministro da Educação do Estado Novo, Gustavo Capanema, apontam para um aprofundamento desta proposta educativa de defesa da pátria, enfatizando um afastamento das ideias escolanovistas:

Entre nós, ainda é vigente a teoria que pode resumir-se na fórmula: "educar para a sociedade". Segundo esta concepção, a educação consiste na socialização da criança e do adolescente, a saber, é o conjunto de processos destinados a adaptar convenientemente o ser humano à vida em sociedade. É fora de dúvida que tal conceito de educação é precário e insuficiente. Não basta realizar a tarefa de sentido algo negativo de adaptar a infância e a juventude à sociedade, [...]. Em nosso país, e principalmente no tempo presente, a educação deve abranger uma finalidade maior. A nossa fórmula de hoje tem que ser esta: educar para a pátria. (Idem; Ibidem)

Com base nestas novas premissas, Capanema dedica bastante atenção ao ensino secundário, alvo de uma reforma implementada pelo Decreto-lei $\mathrm{n}^{\circ} 4.244$ (Lei Orgânica do Ensino Secundário), de $1942^{75}$. O então Ministro atribuía grande valor ao ensino secundário por considerá-lo fundamental na formação de uma cultura geral, bem como por acentuar e elevar a consciência patriótica e humanística nos adolescentes. Neste sentido, defendeu um ensino secundário profundamente patriótico, suficientemente capaz de oferecer aos estudantes a compreensão dos problemas e das necessidades, da missão e dos ideais da nação. Desenvolver no espírito das novas gerações a consciência da responsabilidade diante dos mais altos

\footnotetext{
${ }^{75}$ A Reforma de Gustavo Capanema definiu quatro anos de Ensino Primário e sete no Secundário. Este último foi dividido em ginásio (quatro anos) e colégio (três anos). Os colégios eram subdivididos entre clássico (preparatório para os cursos superiores na área de humanidades) e científico (para as áreas das ciências exatas e biológicas). No período, a Geografia, como disciplina, passou a ter grande destaque em decorrência da sua distribuição no currículo (relação número de aulas semanais/série).
} 
valores da pátria, como sua independência, ordem e seu destino eram alguns dos valores mais valiosos a serem difundidos pelas escolas na visão de Capanema (Ibidem). $\mathrm{O}$ artigo $1^{\mathrm{o}}$ do Decreto $^{76}$ não deixa dúvidas das finalidades esperadas:

Art. $1^{\circ} \mathrm{O}$ ensino secundário tem as seguintes finalidades:

1. Formar, em prosseguimento da obra educativa do ensino primário, a personalidade integral dos adolescentes.

2. Acentuar a elevar, na formação espiritual dos adolecentes, a conciência patriótica e a conciência humanística.

3. Dar preparação intelectual geral que possa servir de base a estudos mais elevados de formação especial.

Para o alcance destas finalidades as disciplinas de Geografia e de História cumpririam um papel basilar para a formação da consciência patriótica, papel esse já estipulado pelo próprio Decreto em seu artigo $n^{\circ} 24 \S 1^{\circ}$ e $2^{\circ}$ :

Art. 24. A educação moral e cívica não será dada em tempo limitado, mediante a execução de um programa específico, mas resultará a cada momento da forma de execução de todos os programas que deem ensejo a esse objetivo, e de um modo geral do próprio processo da vida escolar, que, em todas as atividades e circunstâncias, deverá transcorrer em termos de elevada dignidade e fervor patriótico.

$\S 1^{\circ}$ Para a formação da consciência patriótica, serão com freqüência utilizados os estudos históricos e geográficos, devendo, no ensino de história geral e de geografia geral, ser postas em evidência as correlações de uma e outra, respectivamente, com a história do Brasil e a geografia do Brasil.

$\S 2^{\circ}$ Incluir-se-á nos programas de história do Brasil e de geografia do Brasil dos cursos clássico e científico o estudo dos problemas vitais do país.

A tradução destes objetivos é perceptível na organização das disciplinas pelas séries, como podemos observar a seguir:

\section{$1^{0}$ ciclo - Ginasial, com 4 séries}

\section{Disciplinas}

Português

Latim

Francês

Inglês

Matemática

Ciências Naturais

\section{Séries}

I II III IV

I II III IV

I II III IV

II III IV

I II III IV

III IV

\footnotetext{
${ }^{76}$ Disponível em: https://www2.camara.leg.br/legin/fed/declei/1940-1949/decreto-lei-4244-9-abril1942-414155-publicacaooriginal-1-pe.html Acessado em: 19/09/2021
} 
História Geral

História do Brasil

III IV

Geografia Geral

Geografia do Brasil

III IV

Trabalhos manuais

I II

Desenho

I II III IV

Canto Orfeônico

I II III IV

\section{a) Curso Clássico $-\mathbf{3}$ séries}

\section{$2^{\circ}$ ciclo}

Português

I II III

Latim

I II III

Grego (optativo)

I II III

Francês

optativo

Inglês

optativo

Espanhol

I II

Matemática

I II III

História Geral

I II

História do Brasil

III

Geografia Geral

I II

Geografia do Brasil

III

Física

II III

Química

II III

Biologia

III

Filosofia

III

\section{b) Curso Científico - 3 séries}

$\begin{array}{lr}\text { Português } & \text { I II III } \\ \text { Francês } & \text { I II } \\ \text { Inglês } & \text { I II } \\ \text { Espanhol } & \text { I } \\ \text { Matemática } & \text { I II III } \\ \text { Física } & \text { I II III } \\ \text { Química } & \text { I II III } \\ \text { Biologia } & \text { II III } \\ \text { História Geral } & \text { I II } \\ \text { História do Brasil } & \text { III } \\ \text { Geografia Geral } & \text { I II } \\ \text { Geografia do Brasil } & \text { III } \\ \text { Desenho } & \text { II III } \\ \text { Filosofia } & \text { III }\end{array}$

(ROMANELLI, 1986. p. 157/158)

Predomina o caráter de cultura geral e de humanístico do currículo em todos os ciclos e cursos, além de uma excessiva preocupação com a manutenção de um viés enciclopédico. A pouca diversificação também chama a atenção e parece ter o objetivo exclusivo de preparar para o ingresso no ensino superior. Segundo 
Romanelli (1986), em função destes aspectos, a educação secundária só podia existir "como educação de classe. Continuava, pois, constituindo-se no ramo nobre do ensino, aquele realmente voltado para a formação das 'individualidades condutoras"” (p. 158). O caráter elitista desta reforma é inegável porquanto haveria um grupo de "adolescentes (burgueses) predestinados a conduzir a sociedade e que, por isso, teria acesso a um tipo de ensino específico. Capanema, na exposição de motivos da lei, afirma que este tipo de ensino não poderia se limitar ao simples desenvolvimento dos atributos naturais do ser humano, mas, que tivesse a força de ir além dos estudos de mera formação literária, científica ou filosófica. Outro aspecto importante é que este tipo de educação proporcionasse aos adolescentes uma concepção de homem e do ideal da vida humana, formando assim as individualidades dirigentes, "esclarecidas de sua missão social e patriótica, sendo eles os responsáveis pela divulgação ideológica desses princípios ao povo" (ZOTTI, 2004. p. 108). Dessa maneira, a estrutura da sociedade capitalista, em processo de consolidação sob a égide do Estado Novo, reproduziu a dicotomia da estrutura de classes na educação.

A Geografia obteve grande espaço na proposta de Capanema, estando presente em todas as séries do ensino secundário. Pela primeira vez o programa da disciplina apareceu redigido em unidades didáticas, o que ocultou o detalhamento dos conteúdos a serem trabalhados pelos professores. Vejamos a organização do programa curricular prescrito:

Primeira Série

\section{CURSO GINASIAL}

6 unidades: A Terra no espaço, estrutura da Terra, os grupos humanos, a circulação, a agricultura e a pecuária, indústria e comércio.

\section{Segunda Série}

12 unidades: Geografia Geral, Física, Humana, Política e Econômica dos continentes.

\section{Terceira Série}

7 unidades: Geografia Física e Humana do Brasil.

\section{Quarta Série}

6 unidades: Geografia Regional do Brasil

\section{Primeira Série}

\section{CURSO COLEGIAL (Clássico ou Científico)}


5 unidades: A ciência geográfica, a Terra no espaço, a atmosfera, a hidrosfera, o relevo.

\section{Segunda Série}

5 unidades: América Meridional e Setentrional, Comunidade Britânica, o Continente europeu, a China e o Japão, Indostão, Pérsia, Ásia Menor, Egito.

\section{Terceira Série}

5 unidades: Posição geográfica do Brasil, Fronteiras, Fisiografia do Brasil, Desenvolvimento econômico, Circulação e comércio.

A legislação consolidou uma orientação moderna para o ensino de Geografia e concedeu bastante ênfase ao estudo do Brasil. Por conseguinte, após toda a explanação apresentada, é possível perceber que a disciplina Geografia deveria abordar o espaço com o fito supremo de desenvolver uma consciência patriótica, ou seja, a disciplina tinha como objetivo principal estimular uma ideia de pertencimento, de identidade da sociedade com seu território, forjando uma noção de nação que ama seu Estado, na figura de seu território e das instituições que o gerem, e é por ele acolhido e protegido dos males externos. Nessa retórica há uma clara intenção de mascarar as profundas desigualdades da sociedade brasileira, historicamente construídas e materializadas no espaço urbano e rural, sugerindo que todos somos igualmente responsáveis pelo crescimento da pátria amada. Por conseguinte, a Geografia, juntamente às demais disciplinas, colocavam na ordem do dia a necessidade do trabalho conjunto de toda a sociedade para sanar os problemas nacionais, mascarando as raízes dessas questões e reforçando uma pretensa harmonia entre as classes sociais. Exaltar sentimentos patrióticos e, simultaneamente, escamotear questões radicais da sociedade consistem numa estratégia já conhecida, ou seja, o espaço abordado no currículo escolar da disciplina Geografia funciona como dispositivo difusor de um ideal hegemônico de sociedade porquanto o espaço, não é um produto histórico-social a ser transformado, mas simplesmente um objeto acabado a ser compreendido pelo bem da pátria e de seus cidadãos.

Em suma, portanto, o Estado Novo pôs em voga uma política educacional que procurou transformar a educação em um eficaz instrumento de manipulação das classes subalternizadas. A criação das escolas técnicas profissionalizantes ilustra bem nossa interpretação por ocorrer justamente num período de transformação na infraestrutura econômica, quando a indústria exige uma maior 
qualificação e diversificação da força de trabalho. Esta tarefa ficou a cargo do Estado, que não apenas se propôs a assumir o treinamento da força de trabalho, como o recrutou no interior da nova sociedade de classes em gestação nas cidades. Nesse contexto, a ditadura de Vargas reproduziu no sistema educacional a dicotomia da estrutura de classes capitalista de forma camuflada numa ideologia patriótica e paternalista.

\subsection{O currículo pensado para o projeto de país liberal}

Em 1945 a ditadura de Vargas chegou ao fim e foi substituída logo em seguida por um governo eleito. O governo de Dutra (1946-1951) assistiu a promulgação de uma nova Constituição em 1946, produzida por uma Assembleia Nacional Constituinte e caracterizada pelo forte tom liberal e espírito democrático. Em profundo contraste com o período anterior, a nova Constituição garantia liberdades e direitos individuais, novidades até então. É interessante observarmos que o capítulo II da Carta Magna dispõe "da Educação e da Cultura” e assegura no artigo $\mathrm{n}^{\circ} 168$ "VII - é garantida a liberdade de cátedra" ou ainda no artigo $\mathrm{n}^{\mathrm{o}} 173$ "As ciências, as letras e as artes são livres". Essas garantias conferiram uma maior segurança e legitimidade à prática educativa escolar, o que foi ainda mais reforçada com os artigos $n^{\circ} 166,167$ e $168^{77}$ :

Art 166 - A educação é direito de todos e será dada no lar e na escola. Deve inspirar-se nos princípios de liberdade e nos ideais de solidariedade humana.

Art 167 - O ensino dos diferentes ramos será ministrado pelos Poderes Públicos e é livre à iniciativa particular, respeitadas as leis que o regulem.

Art 168 - A legislação do ensino adotará os seguintes princípios: I - o ensino primário é obrigatório e só será dado na língua nacional;

II - o ensino primário oficial é gratuito para todos; o ensino oficial ulterior ao primário sê-lo-á para quantos provarem falta ou insuficiência de recursos;

III - as empresas industriais, comerciais e agrícolas, em que trabalhem mais de cem pessoas, são obrigadas a manter ensino primário gratuito para os seus servidores e os filhos destes;

IV - as empresas industrias e comerciais são obrigadas a ministrar, em cooperação, aprendizagem aos seus trabalhadores

${ }_{77}$ Disponível em: http://www.planalto.gov.br/ccivil_03/constituicao/constituicao46.htm Acessado em: 20/09/2021 
menores, pela forma que a lei estabelecer, respeitados os direitos dos professores;

Esta Constituição inegavelmente teve forte inspiração ideológica liberaldemocrata e pareceu ter influenciado o então Ministro da Educação Clemente Mariani, que instituiu, em 1946, uma comissão de educadores para estudar e propor uma reforma geral da educação nacional (ROMANELLI, 1986). Em 1948, esse projeto era apresentado na Câmara Federal e deu-se início a um dos mais fecundos períodos de debate ideológico em torno dos problemas educacionais do país, que somente chegou a termo em 1961, 13 anos depois (será a Lei de Diretrizes e Bases da Educação Nacional), após muitas idas e vindas, dissensos e contrassensos ao longo das comissões parlamentares.

Nesse interim é preciso assinalar o retorno de Vargas ao poder, em 1951, através de eleições, retomando de maneira bastante intensa a defesa do nacionalismo. Seu retorno contou com forte apoio da burguesia industrial que ansiava pela retomada da política econômica do Estado Novo, como também encontrou guarida nas camadas populares, contempladas pela legislação trabalhista e pela previdência social.

Todavia, esta combinação se tornou bastante difícil com a forte entrada de capital internacional no mercado interno, oriundo de potências imperialistas em franco processo de expansão econômica mundial. Sodré (1962) afirma que as indústrias de bens de produção forneceram um aumento na utilização de mão de obra, entre 1940 e 1955, de aproximadamente 892\%, as indústrias de bens de consumo de $196 \%$ e a agricultura de $64 \%$. Esses dados atestam uma renovação da estrutura produtiva e, simultaneamente, um rompimento com a economia colonial. Esta ruptura se reflete em todos os campos: há uma transferência de mão de obra das atividades primárias (lavoura, pecuária, indústrias extrativas) para as indústrias de transformação e serviços.

É evidente que estas transformações não se deram de maneira harmoniosa e Vargas parecia o único capaz de implementar um governo como solução de compromisso para atenuar ou omitir as fortes contradições que a sociedade brasileira apresentava. Sodré (idem) considera que Vargas viveu uma situação extremamente delicada, já que 
Ou se apoiava em bases populares ou se divorciava delas; apoiarse em bases populares significaria aprofundar as alterações e desafiar o imperialismo; apoiar-se em bases imperialistas significaria a sua destruição política. O seu suicídio representou o fim de uma época - e o fim de uma política. (p. 334)

A vitória do projeto de internacionalização da economia foi seguida pela eleição de Juscelino Kubitschek (JK), em 1955, com o famoso slogan de desenvolvimento do Brasil "50 anos em 5" (1956-1961). Este projeto recebeu apoio de diferentes setores da sociedade, desde a burguesia industrial e agrária até o operariado urbano sindicalizado. A promessa era desenvolver uma política econômica menos nacionalista e mais desenvolvimentista, inaugurando a segunda fase do modelo de substituição de importações, com forte participação do capital estrangeiro. Recorremos, mais uma vez, a Ianni (1975) que nos explica que a estratégia de JK se calcou na ideia de conciliação, ou seja, "manteve-se e apoiou-se na política de massa, mas realizou um programa de desenvolvimento econômico baseado na internacionalização dos investimentos", ou melhor, "combinou o esquema de sustentação política criado com o modelo getuliano (portanto, de desenvolvimento econômicos nacionalista) e uma política econômica voltada para a internacionalização [...]" (p. 70). Consolida-se um Estado populistadesenvolvimentista sustentado por uma aliança instável entre o empresariado nacional, interessado no avanço da industrialização capitalista, sob o resguardo do protecionismo alfandegário, e camadas populares de aspirações basicamente voltadas ao maior acesso aos bens de consumo e aos mecanismos decisórios políticos. Tais desejos são tacitamente manipulados pela burguesia com o fito de granjear seu apoio contra as antigas oligarquias.

Destarte, JK tentou conciliar o modelo político de massas com o modelo econômico, não tão nacional assim, todavia sua retórica não alcançou a realidade. A defesa do grande capital, do monopólio e internacionalização da economia aprofundou o processo de concentração de renda e inviabilizou aquela tentativa de conciliação entre modelos políticos e econômicos radicalmente distintos. No interior dessa complexa situação, o pacto populista começa a ruir porquanto os interesses antagônicos se tornam inconciliáveis. De um lado, as classes populares pressionam por políticas distributivistas e, de outro lado, o empresariado buscava manter sua lucratividade e acumulação de capital. O primeiro grupo somado à classe média, aos profissionais liberais, às forças armadas, todos pauperizados pela 
inflação, se sentem excluídos dos processos decisórios do Estado, que não mais os representa. Por seu turno, o capital internacional vislumbra no modelo político brasileiro uma barreira ao seu projeto de expansão e de gradual absorção do mercado interno, com o mínimo de freios institucionais ou de interferências reivindicatórias alheias à racionalidade das decisões econômicas.

É em meio a todo esse longo contexto que podemos observar, de forma geral, e mais marcadamente desde o fim do Estado Novo, uma estreita vinculação da educação às necessidades de desenvolvimento econômico, fato que podemos observar através da grande valorização conferida ao ensino profissionalizante, não apenas no nível secundário, mas também no primário, quando se defendeu uma “educação para o trabalho". O perfil elitista e antidemocrático permaneceu inalterado (ZOTTI, 2004). Ghiraldelli Jr (2001) traz importantes informações acerca daquele período ao escrever que

O espírito do desenvolvimentismo inverteu o papel do ensino público, colocando a escola sob os desígnios diretos do mercado de trabalho. Daí a ênfase na proliferação de uma escola capaz de formar mão-de-obra técnica, de nível médio, deixando a universidade para aqueles que tivessem "vocação intelectual". Concretamente, os recursos financeiros entre 1957 e 1959 destinados ao ensino industrial foram quadruplicados. Enquanto isso, o país, em plena ultrapassagem da metade do século XX, manteve a metade de sua população sem o domínio dos conhecimentos básicos da leitura e da escrita. (p. 95)

Este entendimento político persistiu no governo de Jânio Quadros (1961). O início da década de 1960 no país foi profundamente marcado por uma grave crise política e econômica, muito em virtude da herança deixada por JK, como uma elevada inflação, déficit na balança de pagamentos, crescente endividamento externo e a manutenção de um sistema educacional elitista e excludente. Nesse contexto, Jânio estabeleceu como prioridade o combate à inflação com a restrição de créditos, congelamento dos salários e incentivo às exportações, medidas que geraram forte oposição em diversos setores da sociedade. O governo de Jânio não resistiu às fortes contradições existentes no país, tanto no âmbito político quanto econômico, o que resultou em rápido desgaste e em sua renúncia.

É importante destacar que o praticamente incontrolável processo inflacionário estimulou uma ininterrupta luta reivindicatória contra o rebaixamento do poder aquisitivo dos salários. As campanhas salariais e as greves representam a 
luta do operariado contra a deterioração de seu poder de consumo. Também recrudescem as organizações sindicais e os vínculos com os partidos políticos populistas e de esquerda, movimento que demonstra claramente a necessária politização para alcançar conquistas econômicas.

João Goulart assume o governo, em 1961, mantendo-se fiel ao modelo político nacional-desenvolvimentista, mas muda a orientação econômica com a implementação das reformas de base (reforma agrária, reforma do sistema tributário, reforma do sistema bancário, reforma do sistema eleitoral e reforma universitária). Ianni (1975) ao analisar esse período escreve que Goulart é um líder populista e

Traz consigo todos os compromissos e ambiguidades da política de massas. Governa sempre sob as várias pressões que caracterizam a história do populismo. Agora estas pressões estão concentradas, em força e profundidade. Assim, os anos de 196264 são anos de crises políticas sucessivas, no âmbito de uma crise geral do poder burguês, tanto quanto da economia nacional. Essa situação de crise se aprofunda ainda mais com os debates sobre as reformas de base. As campanhas pelas reformas institucionais são um dos fatores que provocam a reaglutinação das forças políticas burguesas. Aliás, setores conservadores e liberais, internos e externos, aliam-se para enfrentar e dar uma solução política à crise. (p. 209/210)

O ano de 1961 é particularmente importante para a educação do país em razão da promulgação da Lei 4.024, que estabeleceu a primeira Lei de Diretrizes e Bases da Educação Nacional. Esta lei refletiu as contradições e os conflitos da sociedade brasileira por conter elementos populistas sem perder seu viés elitista. Assim, segundo Freitag (1980),

Essa lei, que procura estabelecer um compromisso entre os interesses de uma burguesia nacional e os interesses de frações de classe mais tradicionais, ligadas ao capital internacional, em verdade já está ultrapassada, quando entra em vigor. Em dezembro de 1961 já se delineiam claramente as novas tendências de internacionalização do mercado interno. Com isso se anunciam possíveis mudanças na organização do poder ao nível da sociedade política o que certamente iria levar a reformulações da política educacional, visando a sociedade civil. Fato é que essa lei tardia passou a materializar-se na década seguinte nas instituições de ensino. O sistema formal de ensino passou a ser estruturado e reformulado segundo suas prescrições; os currículos redefinidos; professores, alunos e profissionais moldados segundo suas diretrizes. (p. 59) 
Foi em meio a esse cenário turbulento de intenso fogo cruzado entre os setores conservadores e os mais progressistas, assistindo ao solapamento das instituições democráticas, que João Goulart conseguiu avançar em medidas importantes para o desenvolvimento de questões sociais. $\mathrm{O}$ presidente, seguindo determinação da LDB, entre 1961 e 1964, elevou investimento em educação em 5,93\% e lançou o Plano Nacional de Educação (PNE), que, por sua vez, determinou o investimento mínimo de $12 \%$ dos recursos de impostos arrecadados pelo governo federal (ZOTTI, 2004). Foi a partir desta LDB que o ensino secundário e os ramos do ensino técnico-profissional foram reunidos sob a denominação de ensino médio com duração de sete anos e subdivido em dois ciclos (ginasial de quatro anos e o colegial de três anos). Cumpre assinalar que em 1963 uma portaria do MEC regulamentou a "educação moral e cívica" na LDB, que não estava prevista para se tornar uma disciplina específica, mas deixa claro que as atividades escolares deverão concorrer para essa formação, com a acentuação dos aspectos nacionais, além de ser ensinado o hinário e o folclore para estimular a criação de um sentimento de unidade nacional. Não é difícil imaginar que a disciplina Geografia, com seu marcante traço curricular nacionalista-patriótico, exerceu papel de destaque para a "educação moral e cívica" dos estudantes.

O Conselho Federal de Educação (CFE) elaborou algumas recomendações sobre os programas das disciplinas escolares Português, História, Matemática, Ciências, Educação física e Geografia. As recomendações do CFE para a Geografia foram as seguintes:

Geografia: tem por objetivo o estudo da Terra como habitat do homem. O objetivo principal dessa disciplina é estudar as ações e reações entre os fenômenos naturais e culturais, analisando e interpretando fatos relevantes da vida dos grupos humanos sobre o globo. (ZOTTI, 2004. p. 126)

No curso ginasial, a prioridade conferida deveria ser à iniciação geográfica com o fito de fundamentar os conceitos básicos para a compreensão do planeta, em sua dinâmica natural pela promoção de "noções essenciais para a observação da natureza e o estudo da presença do homem necessário" (Ibidem). A "iniciação geográfica" no ciclo ginasial indica o estudo do espaço imediato do estudante, considerando sua localidade, região e país; já no ciclo colegial demanda o aprofundamento dos estudos em Geografia humana e econômica do Brasil e do 
mundo. Outro indicativo importante é a articulação entre as disciplinas de Geografia e de História, conduzindo o "educando à compreensão da correlação entre o desenvolvimento das sociedades e o condicionamento geográfico da localidade e da região" (Ibidem).

A partir deste contexto é possível fazermos algumas considerações balizadas na exposição realizada até aqui. A escola brasileira, considerando as leis implementadas e as organizações curriculares observadas, não apenas reproduz e reforça a estrutura de classes capitalista, mas age em favor da perenização das relações de trabalho que estruturam a sociedade. Ainda é possível assinalar a função difusora ideológica exercida pelas instituições escolares, reproduzindo a concepção de mundo da classe dominante. Conquanto a educação tenha sido uma demanda crescente das classes populares, é gritante a logica capitalista que orienta e fundamenta o ensino ofertado.

Uma perspectiva de análise mais ampla indica que a classe burguesa, já ancorada no poder, estrutura seu sistema escolar determinada a conseguir reproduzir as relações sociais de produção, transmitindo sua ideologia dominante para que os estudantes ajam de acordo com um código de normas e valores oriundo de seus interesses. O "sucesso" dos estudantes segundo os padrões pedagógicos burgueses, criando proximidade com seus esquemas e rituais, acarreta uma ampla defesa e imposição às classes dominadas dos sistemas de pensamento empregados, fazendo-as aceitar sua situação de sujeição à dominação. Não obstante, torna-se incontestável que o sistema escolar promove uma dupla ação simultânea: de um lado, ascende os considerados aptos a participarem de seus esquemas de privilégios e do uso da força do poder, segundo seus parâmetros e processo de seleção e, por outro lado, cria, sob a aparência de neutralidade, sistemas de pensamento que legitimam "a exclusão dos não-privilegiados, convencendo-os a se submeterem à dominação sem que percebam que o fazem" (FREITAG, 1980. p. 26).

Ademais, o capital, segundo Marx, necessita de uma força de trabalho educada e adaptável, e não específica. Se os trabalhadores devem ser educados, quem define o que esse sujeito pode ler ou quais ideias políticas podem conceber? Não temos dúvida que o currículo escolar é o documento que define estes limites e que aponta os caminhos para que essa formação não fuja de seu controle. As reformas apresentadas, as organizações curriculares, bem como a própria LDB de 
1961 não permitem, em nosso entender, outra interpretação. Esta temática é um campo central da reprodução social e Harvey (2016) nos ensina que

Do ponto de vista do capital, os trabalhadores precisam saber apenas o necessário para obedecer às instituições e cumprir suas funções dentro de uma divisão do trabalho por ele criada. Contudo, uma vez que saibam ler, existe o perigo de que os trabalhadores leiam, sonhem e até ajam de acordo com as ideias recolhidas de uma imensa variedade de fontes. Por essa razão, é essencial que haja controle ideológico sobre o fluxo de conhecimento e informação, além do ensino de ideias corretas que apoiem o capital e seus requisitos de reprodução. (p. 123)

Estas palavras corroboram toda a discussão desenvolvida até aqui e permitem que caminhemos em frente. Resta óbvio que o conjunto de disciplinas escolares também foram dispostas para sustentarem os mesmos fins e não temos informações que desmintam essa situação. Neste sentido, a disciplina Geografia, agora presente em todas as séries do ensino secundário, conduz uma abordagem do espaço em semelhança com os períodos anteriores, ou seja, não se registra nenhum movimento ou iniciativa que busque romper com aquela perspectiva dualista cartesiana sujeito-objeto. O que pretendemos chamar a atenção, é como o currículo escolar de Geografia tem reforçado, desde então, um profundo distanciamento do sujeito de sua relação ontologicamente espacial, ou melhor, tem impedido que os estudantes percebam o espaço enquanto produto também de sua ação. Nossa sociedade impõe que a existência objetiva dos indivíduos tenha por pressuposto a sua existência como trabalhadores, condição que se complexifica ao longo do tempo, no decorrer de um processo histórico singular que demonstra como o homem é, ou seja, que manifesta a própria vida em sua condição de existência. Assim, os homens coincidem com sua produção, não apenas com o que produzem, mas como o produzem, inclusive o espaço. Por conseguinte, o produto do trabalho, metamorfoseado em mercadoria, esconde todo um conjunto de relações sociais reificadas.

Nesse contexto é correto pensar que as pessoas servem de apoio para a relação entre objetos e a relação entre os objetos intermedia as relações pessoais. Nesse mesmo raciocínio, a relação entre proprietários privados permite a generalização da propriedade privada, que se realiza através de relações jurídicas específicas desse modo de produção. Pachukanis (2017) ensina que quando a vida econômica é estruturada a partir do acordo entre vontades independentes "então 
toda função social, de modo mais ou menos refletivo, assume um caráter jurídico, ou seja, não se torna simplesmente uma função social, mas um direito de quem desempenha essa função" (p. 112). A sociedade capitalista, por conseguinte, consiste, sobretudo, numa sociedade de proprietários de mercadorias, o que significa que as relações sociais entre as pessoas, em meio ao processo de produção, são reificadas nos produtos do trabalho, que se relacionam entre si pelo valor. A mercadoria, por sua vez, pode ser encarada como um objeto por meio do qual "a diversidade concreta de propriedades úteis se torna simples invólucro reificado da propriedade abstrata de valor, que se manifesta como a capacidade de ser trocada por outras mercadorias a uma proporção determinada" (PACHUKANIS, 2017. p. 119).

As referidas relações jurídicas são materializadas em instrumentos artificiais como leis e contratos, que, em meio ao modo capitalista de produção, legitimam e consagram a apropriação privada dos meios de produção e a acumulação de capital através da exploração do trabalho. A reificação das relações sociais é condição indispensável para que o direito como forma social capitalista possa se realizar, já que os homens não se relacionam somente como coisa, mas também como sujeitos de direito. Porquanto a força de trabalho como mercadoria e o sujeito de direito sejam realidades da sociedade capitalista o indivíduo é sujeito somente em oposição aos objetos. Outrossim, é possível pensar que a vida social se desintegra na sociedade capitalista

Por um lado, na totalidade de relações reificadas que surgem espontaneamente (assim como todas as relações econômicas: nível de preços, taxas de mais-valor, taxa de lucro etc.), ou seja, relações nas quais as pessoas nos dizem menos a respeito que as coisas; por outro lado, na totalidade das relações em que o homem só se determina por meio da oposição com suas coisas, ou seja, como sujeito ou na totalidade das relações jurídicas. Essas duas formas fundamentais, a princípio, diferem uma da outra, mas estão, ao mesmo tempo, intimamente ligadas e condicionam-se mutuamente. O vínculo social da produção apresenta-se, simultaneamente, sob duas formas absurdas: como valor de mercadoria e como capacidade do homem de ser sujeito de direito (PACHUKANIS, 2017. p. 120/121).

Marx dedica grande atenção aos chamados "direitos naturais do homem", “conquistados" pela Revolução Francesa, destacando a reificação das relações sociais, em que os princípios gerais abstratos de organização da sociedade passam 
a consolidar a materialidade objetivada e juridicamente aceita das relações humanas. Dedicando um pouco mais de atenção à ideia de liberdade é possível perceber que se desenvolve a partir de um contrato, garantindo que dois opostos formalizem juridicamente a venda da força de trabalho e a realização da troca como uma relação de vontade. Assim, enquanto o servo estava numa situação de completa subordinação ao senhor porque esta relação de exploração não exigia nenhum instrumento jurídico próprio, o trabalhador assalariado "surge no mercado como um livre vendedor de sua força de trabalho porque a relação capitalista de exploração é mediada pela forma jurídica do contrato" (PACHUKANIS, 2017. p. 118). Nesse sentido, o contrato pode ser encarado como a consagração de uma relação de tratamento igual entre desiguais, resguardando um procedimento jurídico único entre equivalentes meramente formais. Marx (1996) é bastante elucidativo quando afirma que o "escravo romano estava preso por correntes a seu proprietário, o trabalhador assalariado o está por fios invisíveis. A aparência de que é independente é mantida pela mudança contínua dos patrões individuais e pela fictio júris do contrato" (p. 206).

No seio dessa discussão está a constatação de que as capacidades humanas poderem ser adquiridas como propriedades privadas do sujeito que as aliena, cabendo a cada um dispô-las como quiser, fazendo crer que o contrato seja algo produzido livremente. Por conseguinte, o trabalhador ao vender sua força de trabalho passa a consistir, simultaneamente, sujeito e objeto de direito. Nesse sentido, sujeito e objeto estão contraditoriamente opostos à medida que o sujeito vende suas próprias capacidades como algo externo a ele, ou seja, por ser proprietário de sua própria força de trabalho torna-se vendedor do uso temporário de suas capacidades com o fito de adquirir outras mercadorias e valores de uso necessários à sua reprodução.

Mais a frente nos deteremos com maior minúcia sobre a categoria trabalho, justamente para percebermos que as instituições escolares, a partir da construção dos currículos, são legítimos dispositivos políticos que asseguram a produção da mercadoria força de trabalho, ou seja, assim como a relação trabalhador-trabalho, como nos ensina Marx, é uma relação estranhada, posto que o trabalhador desconhece o produto de seu trabalho de transformação da natureza, também podemos pensar que a relação homem-espaço é estranhada porque a categoria 
trabalho mantém-se fetichizada pela forma-mercadoria, permanecendo consagrada enquanto tal pelos currículos escolares. Destarte, os currículos escolares, inclusive o de Geografia, trabalham diretamente a relação sociedade-natureza, funcionando como um exímio agente garantidor da forma-mercadoria.

\subsection{De volta à marcha da ciência geográfica}

Ao analisarmos nosso percurso investigativo entendemos ser interessante expormos algumas considerações sobre o momento vivido pela ciência e, particularmente, pela Geografia, procedimento que nos permitirá compreender com mais clareza as fundamentações curriculares adotadas pelo Estado (burguês), que sustentaram os currículos escolares de Geografia pretéritos, bem como servirão de subsídio político para as próximas reformas curriculares. Em termos operacionais, estamos retomando a marcha de desenvolvimento da ciência geográfica no Brasil, de forma a viabilizar uma interpretação conjunta de todo o contexto que envolve a dimensão curricular, conduta que, posteriormente, será novamente utilizada com fins a estimular a leitura crítica do movimento de renovação política e escolar ocorrido no país, principalmente a partir da década de 1970. Outrossim, a discussão acerca do trabalho poderá ser retomada com fundamentos mais consistentes derivada das explanações que permeiam o mundo do trabalho a partir do final do século XX.

Naquele momento a Geografia Moderna havia entrado em crise, especialmente em virtude do amplo desenvolvimento do sistema capitalista, que havia superado a etapa concorrencial e avançava pela estratégia monopolista, ou seja, se formaram grandes trustes monopolizadoras do mercado. O liberalismo econômico já estava abandonado, juntamente com as teses da livre iniciativa, da ordem natural e da autorregulação do mercado, substituídos pelo protagonismo do Estado no planejamento e regulação da economia. Neste sentido, o planejamento econômico emerge como um instrumento fundamental para a intervenção do Estado, bem como urgiu a necessidade de desenvolver um planejamento territorial para a organização do espaço, fato que alterou a função das ciências humanas. A partir daquele momento o que se espera é a geração de um instrumental de 
intervenção, com viés tecnológico (MORAES, 2005), demanda que a Geografia Moderna não oferecia.

Outro fato relevante foi a complexificação da vida com o desenvolvimento do capitalismo, assim, as cidades proliferavam em altíssima velocidade, provocando fenômenos urbanos até então desconhecidos, o espaço rural também se transformou graças à intensificação da industrialização, as relações interpessoais foram multiplicadas pela expansão das redes de comunicação, enfim o espaço terrestre era tomado por relações econômicas diversas e o mercado se transnacionalizava. Destarte, restou óbvio a defasagem do instrumental geográfico tradicional para abordar a realidade daquele período, o que incentivou um movimento de renovação da ciência a procura de novas técnicas para a análise geográfica (Ibidem).

Um último aspecto a ser levantado é o questionamento acerca da fundamentação filosófica que sustentava a Geografia Moderna, o positivismo clássico. Portanto, a Geografia Moderna, de cunho positivista foi pensada como ciência neutra e útil e sob estes princípios estão de acordo a Geografia e o próprio Positivismo. Todavia, o desenvolvimento da ciência, como já aventado, ultrapassou as premissas positivistas e, por conseguinte, emerge a crítica advinda de diferentes horizontes, como a da perspectiva Neopositivista e a caráter marxista, ambas atingiram a Geografia Moderna pela crítica ao método e à falta de construção teórica (SUERTEGARAY, 2005).

Neste momento concentraremos nosso olhar na crítica Neopositivista, que derivou na chamada Geografia Pragmática ou Teorética ou Quantitativa, tendo em vista o período que estamos analisando o contexto educacional nacional e sabendo que as proposições marxistas vão encontrar maior entrada nas políticas curriculares oficiais apenas em período posterior. A Geografia Pragmática concentrou a sua crítica no método científico positivista, não questionando seus fundamentos e sua base social (MORAES, 1995). Neste sentido, os geógrafos pragmáticos buscaram oferecer um conhecimento prospectivo, habilitado a partir de novas técnicas e de uma nova linguagem a desenvolver ações de planejamento.

Portanto, a crítica pragmática está restrita ao nível formal, uma crítica meramente metodológica que não tocou nos compromissos sociais do pensamento 
tradicional porquanto os compromissos estão mantidos, ou seja, as ciências humanas continuam a serviço das classes dominantes. Assim, segundo Moraes (idem), há uma mudança da forma e a manutenção do conteúdo social, uma renovação conservadora, passando de um "conhecimento que levanta informações e legitima a expansão das relações capitalistas, para um saber que orienta esta expansão, fornecendo-lhe opções e orientando as estratégias de alocação do capital no espaço terrestre" (p. 110).

Não é nosso objetivo mergulharmos profundamente nos aspectos teóricos do pensamento neopositivista, todavia é importante fazermos uso do pensamento de Suertegaray (Idem) que nos ensina

Os pressupostos desta nova Epistemologia, reconhecida posteriormente por Neopositivismo parte da valorização da experiência, dos dados, da realidade empírica como princípio do conhecimento, propõe o abandono da relação causal e indica a substituição da função (relação de causa e efeito) pela probabilidade. Além disto, questiona a indução como processo único. Propõe a linguagem objetiva na produção do conhecimento, dando ênfase à matemática e à lógica formal na construção científica. (p. 20)

De forma a complementar esta discussão teórica, Gomes (1996), ao abordar o chamado horizonte lógico-formal na Geografia moderna, afirma que no período entre guerras houve um grande desenvolvimento segmentado do pensamento científico e um dos ramos foi justamente o positivismo lógico, ou neopositivismo ou filosofia analítica, que se estabeleceu primeiro sobre os domínios da matemática e da física, e, em seguida, às outras ciências, à psicologia, sociologia, biologia e economia. Neste sentido, ainda segundo o supracitado autor,

Para a filosofia analítica, somente a linguagem matemática pode ser legítima como instrumento de conhecimento, pois só ela sabe restringir sua importância aos limites impostos pela lógica. [...] A consequência imediata desta corrente foi a valorização das ciências matemáticas como o novo paradigma metodológico. As outras disciplinas deveriam buscar, no modelo da matemática, sua coerência, rigor, objetividade. (p. 253)

É fundamental salientar que os currículos escolares não consistem em caixas de ressonância das transformações em curso na ciência e na academia, o que significa afirmar que a Geografia Teorética, como veremos, não se materializou de forma explícita nos currículos de Geografia. As razões dessa situação serão 
devidamente explicadas mais à frente, todavia não podemos nos furtar de observar como a transformação da ciência, a despeito de seus aspectos mais específicos, ao ter passado ao largo dos currículos escolares, indica, por outro lado, a persistência da Geografia Clássica com seus traços característicos e finalidades já conhecidas.

É digno de nota percebermos que a disciplina Geografia, até este momento, manteve sua práxis escolar estritamente vinculada às orientações positivistas tradicionais, presa às aparências e à reprodução dos aspectos diretamente relacionado ao mundo visível. Destarte, no período que apresentaremos na próxima sessão, a Geografia Teorética nos parece ter entrado nas escolas de outra forma, ou melhor, a perspectiva neopositivista, que impregnou a ciência geográfica, parece se manifestar no currículo escolar através do incentivo a um ensino técnico esvaziado de sentido para o simples preparo para o mercado de trabalho. Neste sentido, a disciplina Geografia vai dispor seu cabedal de informações para viabilizar a formação de mão de obra, alterando sua organização curricular e mantendo seu compromisso com as classes dominantes para a reprodução das relações capitalistas de produção.

\subsection{Que currículo é esse, militar?}

De início é fundamental reafirmar que nosso intuito está longe de desenvolver um mergulho teórico-conceitual profundo em torno das questões políticas e históricas que envolvem o golpe civil-militar de 1964, como também não é escopo a discussão acerca dos movimentos de resistência que se sucederam e cujas consequências já são bastante conhecidas. Na realidade, nosso objetivo, assim como nas sessões anteriores, é apresentar um contexto geral do período e a partir das premissas fundamentais apresentadas desenvolver com maior minúcia as temáticas pertinentes ao currículo escolar e à Geografia escolar.

A ditadura civil-militar durou 21 anos e sua constituição carece de maior atenção. Após o esgotamento, no início da década de 1960, da política de substituição de importação porquanto a maior parte da demanda por bens de consumo duráveis e não duráveis já era atendida pela produção nacional. Não obstante, o processo a acumulação de capital exigia um crescimento dinâmico da 
demanda. Freitag (1980) aponta dois caminhos para que esta necessidade fosse plenamente cumprida,

A primeira seria a realização de reformas estruturais (por exemplo, a agrária) que permitissem a inclusão de massas populares num padrão de consumo democratizado. Era a política mais ou menos explícita do Estado populista, que se frustrou quando a burguesia nacional sentiu que em sua aliança com as classes populares poderia perder o controle do processo reformista. [...] O outro caminho seria a criação de uma demanda adicional, através de uma reorganização da estrutura do consumo interno e do aproveitamento das possibilidades do mercado externo. Este caminho implicava, por um lado, uma aristocratização dos padrões de consumo interno e, por outro lado, exportações maciças, principalmente de produtos manufaturado e semimanufaturados. (p. 73)

Este contexto macroeconômico pode ser mais bem compreendido quando observamos a situação política e social nas maiores metrópoles do país. Não é exagero afirmar que os dias que antecederam ao golpe foram tomados por uma ampla campanha de opinião pública, dirigida especialmente à classe média das principais capitais, para aceitarem antecipadamente a queda do governo de Jango, a modificação drástica das instituições políticas e um reordenamento das políticas econômicas.

Na Guanabara, no dia 13 de março de 1964, o presidente João Goulart, acompanhado de Ministros de Estado, líderes nacionalistas, operários, estudantes, intelectuais etc., realizou um comício na Central do Brasil, que contou com forte apoio do proletariado urbano. O discurso de Jango pode ser encarado como um compromisso público com as reformas de base, especialmente a agrária, e com as liberdades democráticas e sindicais, demonstrando o objetivo de fazer frente aos críticos e evidenciar publicamente as forças que estavam ao seu lado na luta pelas mudanças. Alguns dos trechos mais importantes ditos naquela noite foram:

[...] Dirijo-me a todos os brasileiros, e não apenas aos que conseguiram adquirir instrução nas escolas. Dirijo-me também aos milhões de irmãos nossos que dão ao Brasil mais do que recebem e que pagam em sofrimento, pagam em miséria, pagam em privações, o direito de serem brasileiros e o de trabalhar de sol a sol pela grandeza deste país. [...]

[...] Vamos continuar lutando pela construção de novas usinas, pela abertura de novas estradas, pela implantação de mais fábricas, de novas escolas, de hospitais para o povo sofredor; mas sabemos, trabalhadores, que nada disso terá sentido profundo se 
ao homem não for assegurado o sagrado direito ao trabalho e a uma justa participação no desenvolvimento nacional. [...]

[...] Por outro lado, não receio ser chamado de subversivo pelo fato de proclamar - e tenho proclamado e continuarei proclamando nos recantos da Pátria - a necessidade da revisão da Constituição. Há necessidade, trabalhadores, da revisão da Constituição da nossa República, que não atende mais aos anseios do povo e aos anseios do desenvolvimento desta Nação. A Constituição atual, trabalhadores, é uma Constituição antiquada, porque legaliza uma estrutura sócio-econômica já superada, uma estrutura injusta e desumana. O povo quer que se amplie a democracia, quer que se ponha fim aos privilégios de uma minoria; quer que a propriedade da terra seja acessível a todos; que a todos seja facilitado participar da vida política do país, através do voto, podendo votar e ser votado; que se impeça a intervenção do poder econômico nos pleitos eleitorais e que seja assegurada à representação de todas as correntes políticas, sem quaisquer discriminações, ideológicas ou religiosas.

Todos, todos os brasileiros, todos têm o direito à liberdade de opinião, de manifestar também sem temor seu pensamento. [...]

O comício recebeu mais de 150 mil pessoas e teve repercussões imediatas em virtude do viés nacionalista-reformista adotado pelo presidente. As oposições dos setores dominantes do país e de grande parte da classe média e do oficialato logo se apresentaram em manifestações antigovernamentais em cidades importantes, como São Paulo e Belo Horizonte. Na Guanabara, o governado Carlos Lacerda, afirmou que o comício simbolizou um ataque à Constituição e o discurso de Jango teve tom subversivo e provocativo. É imprescindível mencionar a "Marcha da Família com Deus pela Liberdade", realizada na capital paulista em 19 de março de 1964, ou seja, apenas seis dias após o comício de Jango.

Os principais articuladores do evento foram o governador de São Paulo, Ademar de Barros, e algumas organizações civis, como a Campanha da Mulher pela Democracia (Camde), a União Cívica Feminina, a Fraterna Amizade Urbana e Rural, entre outras entidades e é preciso destacar o apoio da Federação das Indústrias do Estado de São Paulo (FIESP). O jornal Folha de São Paulo assim noticiou o evento:

A Capital paulista viveu ontem o maior dia de toda a sua história. Em formação compacta e na mais perfeita ordem, cerca de 500.000 democratas de todas as condições sociais, constituindo verdadeira torrente humana, desfilaram durante horas pelas ruas do centro, transformando a "Marcha da Família com Deus pela Liberdade" na maior manifestação cívica jamais realizada nos quatrocentos e dez anos de vida de nossa metrópole. (apud IANNI, 1975. p. 130) 
A manifestação teve a adesão de lideranças políticas importantes, como do próprio governador da Guanabara e do presidente do senado (Auro de Moura Andrade). A caminhada foi concluída na Praça da Sé com a celebração de uma missa (pela "salvação da democracia") e com a distribuição de um manifesto de convocação da população contra João Goulart. Neste contexto é possível afirmar que a Marcha teve forte matiz reacionário e procurou defender as "tradições brasileiras" (Deus. pátria e tradição), com uma explícita devoção ao autoritarismo.

Todo esse turbulento cenário foi constituído num período de intensa urbanização e industrialização, processos que proporcionaram grande crescimento no mercado de trabalho dos setores secundário e terciário. Por conseguinte, esses grupos se tornaram fundamentais no jogo político implementado pelas classes dominantes, que buscavam manobrá-los segundo seus próprios interesses. Estes sujeitos ambicionavam ascensão social a qualquer custo e já estavam bastante impregnados pelas ideias, valores e padrões das classes dominantes, difundidos pelas emissoras de televisão, pelos rádios, cinemas etc. Não é por outra razão que entendem as lutas e reivindicações do proletariado como uma ameaça aos seus objetivos pessoais, ou seja, o operariado urbano "atemoriza a massa da classe média. Em consequência, esta se apega mais facilmente às soluções autoritárias, que alguns setores da classe dominante lhe apresentam" (IANNI, 1975. p. 130).

Naquele momento de colapso do Estado populista ocorreu uma profunda reorganização da produção industrial sustentada por novas técnicas produtivas em concomitância com a garantia de crescimento de setores mais sofisticados (indústria química, eletrônica e automobilística), ou seja, efetivou-se um novo período de industrialização sob o comando dos grandes consórcios internacionais. As grandes empresas internacionais (as multinacionais), buscando novos mercados para se instalarem, exigiram a expansão do mercado consumidor, ou seja, fez-se necessário garantir o crescimento do poder de comprar dos consumidores. Essa exigência aparentemente se chocou com outra necessidade, ainda mais importante, que foi o congelamento dos salários dos trabalhadores para atrair as multinacionais ao país e assegurar a maior taxa de lucro possível.

O grande desafio consistiu em estruturar uma política salarial e de distribuição de renda que conseguisse, ao mesmo tempo, congelar os salários da classe trabalhadora e criar uma classe intermediária de alta renda apta para o 
consumo da produção multinacional. Assim, percebemos uma reorganização da sociedade política e da sociedade civil, segundo perspectiva de Gramsci, conforme nova tendência da internacionalização da economia e do mercado interno.

Este novo rearranjo econômico, político e social do país é acompanhado por uma reorganização da própria estrutura de classes, uma vez que grande parte da burguesia nacional se submeteu à burguesia internacional a fim de defender seus interesses de classe. A burguesia nacional juntamente com outros setores da classe média também foram cooptados e se tornaram fundamentais para a implantação e manutenção do novo modelo, destaque para os intelectuais e os tecnocratas. Dessa forma, a burguesia nacional, associada ao capital internacional, usufruiu dos lucros garantidos pelo congelamento dos salários dos trabalhadores, e os setores médios, incorporados ao modelo como assalariados bem remunerados, vão sustentar grande parte do consumo dos bens industrializados produzidos. Por outro lado, "as classes subalternizadas, excluídas de qualquer participação tanto política quanto econômica, precisam ser privadas de seus mecanismos democráticos" para assegurar o adequado funcionamento do sistema de reprodução capitalista, o que implicou também na necessidade de os aparelhos repressivos do Estado assumirem "o controle dos mecanismos e aparelhos ideológicos (sindicatos, meios de comunicação de massa e escolas)" (FREITAG, 1980. p. 77).

O que assistimos, a partir de 1964, foi a formação de um Estado autoritário e violento decidido a alinhar a ideologia ao modelo econômico, ou seja, o autoritarismo e a violência podem ser entendidos como instrumentos de tentativa de controle da sociedade civil com o uso de intervenções em sindicatos, repressão às organizações representativas de trabalhadores e estudantes, extinção de partidos políticos e exclusão das classes trabalhadoras e de seus aliados da esfera política. Nesse contexto, a política educacional pode ser encarada como uma das melhores expressões dessa reordenação das formas de controle social e político porquanto foi colocada quase que exclusivamente a serviço dos interesses econômicos. Não é de outra forma, que as classes subalternizadas enxergam na educação a possibilidade, talvez a única, de alcançarem remuneração superior e de adquirirem maior poder de consumo.

Acerca disto, Ianni (1975) assevera que a maior procura por escolas, principalmente as de ensino médio, é um indicativo do processo de busca incessante 
por ascensão social em meio a expansão da urbanização e industrialização. Esse estudioso afirma que "a escolarização, a urbanização e o crescimento do setor terciário são processos interligados, fundamentais para explicar a importância da classe média no processo político brasileiro" (p. 132). Desde a nossa perspectiva analítica, estas considerações são fundamentais por nos apontarem um caminho investigativo que vincula o contexto socioeconômico e político com a organização do sistema educacional e, consequentemente, com as políticas curriculares implementadas.

Ao longo dos 21 anos de ditadura algumas medidas políticas foram impostas e, de acordo com nossos objetivos, dedicaremos maior esforço investigativo em alguns decretos e pareceres, apresentados antes e depois da nova Constituição de 1967, e na lei 5.692/71, que reforma o ensino de $1^{\circ}$ e $2^{\circ}$ graus. Essa escolha é derivada de análise daquele período, em que alguns estudiosos identificam dois momentos principais: o primeiro foi de implantação do regime e adoção de uma política de recuperação econômica, quando se verificou um aumento da demanda social por educação e, consequentemente, um agravamento da crise do sistema educacional; o segundo decorre da aplicação de medidas práticas para a adequação do sistema educacional ao modelo de desenvolvimento econômico que se intensificou no Brasil, como é possível perceber com a promulgação da referida lei 5.692 (ROMANELLI, 1986).

Castelo Branco, ainda em meados de 1964, dá o tom da educação a partir de então em mensagem aos secretários de educação, afirmando que o objetivo do seu governo seria o de restabelecer a ordem e a tranquilidade entre estudantes, operários e militares (FREITAG, 1980). Este ponto de partida orientou toda a construção do sistema educacional brasileiro, ainda antes da Constituição de 1967, como o parecer n. 117 de 1964 acerca do estabelecimento da Educação moral e Cívica (EMC) no ensino médio a pedido de entidades cívicas femininas. O CFE responde ao pedido com as seguintes palavras:

O momento atual, do Brasil e do mundo, está a exigir, efetivamente, maior atenção para a formação da consciência dos adolescentes, quanto ao exercício dos seus deveres morais e cívicos. Trata-se do que há de mais essencial e básico na educação integral do homem. (BRASIL, 1964, apud ZOTTI, 2004. p. 149) 
Resta reluzente a insistência num sentimento patriótico, nos deveres cívicos como instrumentos ideológicos para a consolidação do regime em todas as suas dimensões. Em 1966 são decretadas normas sobre a EMC em todo o país por meio do decreto n. 58.023, cabendo ao Departamento Nacional de Educação estimular nacionalmente a EMC. O Objetivo desta educação segundo o decreto era:

\begin{abstract}
Art. $2^{\circ}$ A educação cívica visa a formar nos educandos e no povo em geral o sentimento de aprêço à Pátria, de respeito às instituições, de fortalecimento da família, de obediência à Lei, de fidelidade no trabalho e de integração na comunidade, de tal forma que todos se tornem, em clima de liberdade e responsabilidade, de cooperação e solidariedade humanas, cidadãos sinceros, convictos e fiéis no cumprimento de seus deveres $^{78}$.
\end{abstract}

A EMC se tornou obrigatória como prática educativa, e não como disciplina, nas escolas, devendo ser uma preocupação de todo o corpo docente, em especial daqueles professores ligados às disciplinas que com ela tenham conexão, como linguagem, geografia, história, música, educação física e desportos, artes plásticas, artes industriais, teatro escolar, recreação (art. 3). No art. 4, a legislação afirma a importância de uso de todos os veículos de difusão cultural, como os jornais e as revistas, o cinema e o teatro, o rádio e a televisão, os clubes de esportes e de recreação para despertar os ideais e hábitos desejados.

O passo seguinte ${ }^{79}$ foi a promulgação do decreto-lei n. 869 de 12/09/1969, que dispõe sobre "Dispõe sobre a inclusão da Educação Moral e Cívica como disciplina obrigatória, nas escolas de todos os graus e modalidades, dos sistemas de ensino no País, e dá outras providências." ${ }^{~}$. Tornada disciplina obrigatória e ainda como prática educativa, para todos os graus e modalidades, a EMC deveria ser complementada, no grau médio, pela disciplina "Organização Social e Política

\footnotetext{
78 Disponível em: https://www2.camara.leg.br/legin/fed/decret/1960-1969/decreto-58023-21marco-1966-398553-publicacaooriginal-1-pe.html Acessado em: 25/09/2021

${ }_{79}$ Cumpre ao menos mencionar que a promulgação da Constituição em 1967 também surtiu impactos na organização do sistema educacional nacional. Em seu Título IV (da Família, da Educação e da Cultura), no art. 168 a lei estabelece que: "A educação é direito de todos e será dada no lar e na escola; assegurada a igualdade de oportunidade, deve inspirar-se no princípio da unidade nacional e nos ideais de liberdade e de solidariedade humana." ${ }^{.79}$. A Constituição reforçou a participação do ensino particular, movimento já indicado na Constituição de 1961, ao lhe assegurar ajuda técnica e financeira, inclusive financiando bolsas de estudo (art. 168 § 2), ampliou a obrigatoriedade do ensino primário de 4 para 8 anos na rede oficial.

80 Disponível em: https://www2.camara.leg.br/legin/fed/declei/1960-1969/decreto-lei-869-12setembro-1969-375468-publicacaooriginal-1-pe.html Acessado em: 25/09/2021.
} 
Brasileira" (OSPB), conforme assegura o art. $3 \S 1$. É bastante interessante apresentarmos o art. 2 que apresenta as finalidades da EMC:

Art. $2^{\circ}$ A Educação Moral e Cívica, apoiando-se nas tradições nacionais, tem como finalidade:

a) a defesa do princípio democrático, através da preservação do espírito religioso, da dignidade da pessoa humana e do amor à liberdade com responsabilidade, sob a inspiração de Deus;

b) a preservação, o fortalecimento e a projeção dos valôres espirituais e éticos da nacionalidade;

c) o fortalecimento da unidade nacional e do sentimento de solidariedade humana;

d) a culto à Pátria, aos seus símbolos, tradições, instituições e aos grandes vultos de sua historia;

e) o aprimoramento do caráter, com apoio na moral, na dedicação à família e à comunidade;

f) a compreensão dos direitos e deveres dos brasileiros e o conhecimento da organização sócio-político-ecônomica do País; g) o preparo do cidadão para o exercício das atividades cívicas com fundamento na moral, no patriotismo e na ação construtiva, visando ao bem comum;

h) o culto da obediência à Lei, da fidelidade ao trabalho e da integração na comunidade.

Para nós é bastante claro o interesse do Estado em garantir a divulgação e reprodução de sua ideologia dominante, estratégia que nos remete diretamente ao pensamento de Gramsci acerca do exercício da hegemonia pela classe dominante, e que Apple (2011) tão bem soube desenvolver ao tratar das relações hegemônicas quando escreveu que

Há duas exigências para a hegemonia ideológica. Não é que nossa ordem econômica simplesmente "crie" categorias e estruturas de sentimento que saturam nossas vidas diárias. Acrescente-se a isso um grupo de "intelectuais" que empregam e dão legitimação a essas categorias, que fazem as formas ideológicas parecerem neutras. (p. 44)

Seria uma análise bastante ingênua afirmar que as disciplinas escolares estavam apenas interessadas em alcançar aqueles objetivos apresentados no decreto, por mais fantasiosos que possam parecer. A EMC pode ser compreendida como a materialização, no interior das instituições escolares e nos documentos curriculares, da ação do Estado em prol da manutenção da hegemonia burguesa, camuflando estes interesses como reivindicações populares (da classe média) e democráticas e costurando uma íntima relação entre a estrutura e a superestrutura. Portanto, entendemos que o currículo escolar oficial, banhado pelas ideias morais e 
cívicas da hegemonia dominante e espraiado em diferentes disciplinas, funcionou como expressão concreta da aliança entre sociedade política e sociedade civil, em uma relação orgânica que sustenta a dominação burguesa ao combinarem consenso e coerção. A via investigativa gramsciana nos leva a perceber, com a ajuda de Coutinho (1992), que

[...] A necessidade de conquistar o consenso ativo e organizado como base para a dominação - uma necessidade gerada pela ampliação da socialização da política - criou e/ou renovou determinadas objetivações ou instituições sociais, que passaram a funcionar como portadores materiais específicos (com estrutura e legalidade próprias) das relações sociais de hegemonia. E é essa independência material - ao mesmo tempo base e resultado da autonomia relativa assumida agora pela figura social da hegemonia - que funda ontologicamente a sociedade civil como uma esfera própria, e que funciona como mediação necessária entre a estrutura econômica e o Estado-coerção. (p. 129)

Por conseguinte, analisando essa explícita relação entre política, economia e escola podemos perceber que o currículo escolar atua ideologicamente para garantir a certeza de que a forma capitalista de sociedade é a única possível. Através das disciplinas escolares as classes sociais aprendem quais são seus papeis nas relações sociais, construção ideológica que se manifesta no vínculo existente entre os códigos dominantes do currículo e a reprodução de formas de consciência. Esta conduta política guarda profunda conexão com as questões ontológicas justamente por compreendermos a ideologia como fato estritamente ontológico por alterar a vida humana, ou seja, a educação não é nada além de uma ação ideológica intencional sobre outros homens, cuja finalidade é a reprodução permanente da ordem capitalista hegemônica.

A indicação n. 8/1970, elaborada pelo CFE, corrobora nossa perspectiva ao expressar as principais preocupações que pautam a necessidade de tornar obrigatória o estudo moral e cívico pela juventude brasileira. $\mathrm{O}$ documento afirma que

A educação da juventude brasileira à luz dos princípios morais e de civismo que são parte do patrimônio espiritual do Brasil, de um lado sempre foi uma necessidade, de outro lado se apresenta, hoje, com a gravidade e a urgência de um imperativo. No instante em que o país escolhe o seu caminho, no meio da tempestade, e em que se delineiam os grandes ideais da Nação, importa, mais do que nunca, que os jovens recebam, na escola, a formação 
espiritual e democrática que constituem a inspiração profunda de nossa Pátria. Assim sendo, o esforço despendido, para que se ponha em prática o estabelecido pelo Decreto-Lei $\mathrm{n}^{\circ} 869$, de $12 / 09 / 1969$, tem o mais alto sentido e é digno de entusiasmo e do apoio de todos. (BRASIL, 1971 apud ZOTTI, 2004. p. 154)

Acreditamos não restar dúvida da radical relação entre educação e ontologia, ou seja, entre ciência e ser na construção de um domínio hegemônico não apenas político, mas também econômico, como desejou a classe burguesa nacional. Importa afirmar que o currículo escolar, no seio desta discussão, não escapa à sua condição de produto histórico-social, impelindo considerar o rol de conhecimentos escolhidos como os mais relevantes para os objetivos dominantes daquele período. Neste sentido, e avançando em nosso estudo, analisaremos o currículo a partir da reforma do ensino de $1^{\circ}$ e $2^{\circ}$ graus pela lei 5.692/71.

\subsubsection{A lei $5692 / 71$ e os estudos sociais}

A reforma do ensino de $1^{\circ}$ e $2^{\circ}$ graus empreendida pela lei 5.692/71 pode ser entendida como uma tentativa de correção de rota, iniciada pela LDB de 1961. A partir daquela lei o ensino profissionalizante passou a ser utilizado pelas classes subalternizadas como um meio de ascensão para alcançar o diploma formal necessário ao ingresso no ensino superior. Portanto, não ocorreu uma profissionalização de nível médio, mas uma corrida pela universidade, o que aumentou a pressão pela expansão das vagas no ensino superior (FREITAG, 1980). Em suma, a lei não buscou apenas corrigir problemas presentes na estrutura de $1^{\circ} \mathrm{e}$ $2^{\circ}$, mas procurou ajustar ideológica, estrutural e funcionalmente os três níveis de ensino a realidade política e econômica daquele período.

Freitag (idem) sintetiza as inovações trazidas pela nova legislação em três tópicos:

1. Extensão definitiva do ensino primário obrigatório de 4 a 8 anos (Art. 18), gratuito em escolas públicas (art. 20) e consequente redução do ensino médio de 7 para 3 a 4 anos (art. 22). $\mathrm{O} 1^{\mathrm{o}}$ ciclo ginasial fica, portanto, absorvido pelo ensino primário, tornando obrigatório para todos.

2. Profissionalização do ensino médio (antigo $2^{\circ}$ ciclo do ensino médio) (Art. 4, $\S \S 1$ a 5, a art. 10) garantindo ao mesmo tempo continuidade e terminalidade dos estudos.

3. Reestruturação do funcionamento do ensino no modelo da escola integrada, definindo-se um núcleo comum de matérias 
obrigatórias e uma multiplicidade de matérias optativas de escolha do aluno. (p. 94)

Como já salientado anteriormente, não temos o interesse de desenvolver uma ampla análise em torno da LDB, uma vez que concentraremos nosso olhar nos aspectos diretamente relacionados à disciplina escolar Geografia. Todavia é interessante, ao menos, nos indagarmos acerca da extensão da escolaridade obrigatória. Esta medida estava relacionada ao slogan do "Brasil-potência", procurou apresentar à sociedade brasileira o desejo de alavancar o desenvolvimento do país pela superação do analfabetismo e pelo aumento da baixa média de escolaridade do brasileiro. Ou seja, na realidade, consistiu numa velada tentativa do Estado de encontrar maior legitimidade perante a opinião pública através de uma aparência de igualdade de oportunidades e neutralidade em relação às classes sociais, mascarando as desigualdades crescentes pela expansão econômica concentradora de renda.

Particularmente no que concerne à disciplina escolar Geografia, o CFE divulgou o parecer n. $853 / 71$, em que retirou de cena a antiga classificação das matrizes curriculares escolares - Ciências e Humanidades -, fazendo desaparecer a divisão entre Português, História, Geografia, Ciências naturais e Matemática e colocou no lugar um núcleo comum ${ }^{81}$, a partir de uma classificação tríplice, que continha as seguintes matérias: comunicação e expressão, estudos sociais e ciências, definindo, também, as linhas gerais dos conteúdos específicos de cada matéria (BRASIL, 1971 apud ZOTTI, 2004. p. 176). No interior da matéria fixada estudos sociais constavam como conteúdos específicos Geografia, História e a Organização Social e Política do Brasil. O objetivo desta mudança foi “a integração temporal e social do educando em âmbitos gradativamente mais amplos" (Ibidem), cabendo à Geografia o estudo da terra e dos fenômenos naturais referidos à experiência humana. Destarte, Chagas (1993) ao analisar os fundamentos políticocurriculares da legislação acredita que

\footnotetext{
${ }^{81}$ A reestruturação do funcionamento do ensino foi outra inovação da lei, que definiu que os currículos de $1^{\circ} \mathrm{e} 2^{\circ}$ graus teriam um "núcleo comum", obrigatório em âmbito nacional, e uma "parte diversificada" para atender, conforme as necessidades e possibilidades concretas, às peculiaridades locais. Portanto, o "currículo pleno" da escola se constituiu das matérias fixadas segundo aqueles dois grupos de disciplinas, sendo composto, por um lado, de uma educação geral e outra de formação especial. No $1^{\circ}$ grau, a educação geral é exclusiva nas series iniciais e predominante nas series finais; no $2^{\circ}$ grau a formação especial é predominante porquanto seu objetivo é a habilitação profissional.
} 
O fulcro do ensino, a começar pelo "estudo do meio", estará no aqui e no agora do mundo em que vivemos e, particularmente, do Brasil e do seu desenvolvimento [...] O legado de outras épocas e a experiência presente de outros povos, se de um lado devem levar à compreensão entre os indivíduos e as nações, têm que de outra parte contribuir para situar construtivamente o homem em sua "circunstância". (p. 403)

Ainda que grande parte da rede de escolas privadas e alguns estabelecimentos públicos, como o Colégio Pedro II, não tenham seguido as orientações da LDB, entendemos ser importante pensarmos como o documento oficial de ensino do Estado brasileiro entendeu a disciplina Geografia. Neste sentido, é bastante evidente a intenção da legislação de transformar a Geografia e a História em disciplinas inexpressivas e, ao mesmo tempo, fragmentar os respectivos conhecimentos. Conti (1976), em artigo de forte posicionamento, afirma que os Estudos Sociais apresentavam um conteúdo difuso e mal determinado, não restando claro se se tratava de uma área de estudo ou de uma disciplina escolar. Nesse sentido, era como se os "Estudos Sociais" vagasse entre sinônimo de Geografia humana e um pretenso substituto da História, ou ainda como um aglutinador de todas as ciências humanas.

Cumpre destacar que esta denominação "Estudos Sociais" já havia sido utilizada no século XIX, mais precisamente em 1838, no regulamento para o ensino secundário do Colégio Pedro II. Naquele período os "Estudos Sociais" configurou uma grande área composta por Geografia e História e que delineavam um grande quadro informativo acerca do mundo e das sociedades, ou seja, as disciplinas tinham o objetivo de locupletar a classe dominante de dados e registros em seu processo de preparo para a máxima erudição possível. Uma diferença importante foi a manutenção autônoma das disciplinas Geografia e História, conduta que não se verifica na nova organização curricular. Neste sentido, não é de se estranhar que a LDB de 1971 retome esta denominação justamente em um período de fortalecimento do ensino tecnicista e de pouca valorização do exercício de criticidade. Se no século XIX, o ensino elitista formalizou os "Estudos Sociais" para promover a transmissão de informações para a formação de uma classe dirigente, na década de 1970 o objetivo pareceu ser robustecer a reprodução de conhecimentos que viabilizassem prioritariamente o patriotismo acrítico e o preparo intensivo para o mercado de trabalho. 
A despeito de toda a reação gerada no meio acadêmico e entre a classe docente acerca destas medidas, bem como dos efeitos práticos provocados nos cursos de licenciatura, o que nos interessa é propriamente refletir em torno dessa perspectiva curricular oficial. Ao recorrermos mais uma vez ao trabalho de Chagas (idem), encontramos fortes indícios de um verdadeiro esforço político para "enquadrar" a disciplina Geografia (e a História), ou seja, a disciplina foi alvo de um relativo esvaziamento em favor da desconsideração dos problemas sociais vividos pelo país e pelo realce ao patriotismo. Estas considerações encontram embasamento quando percebemos o forte desejo de integração entre as disciplinas, estratégia que forçou uma espécie de "contaminação" da disciplina por outras, a OSPB. O supracitado autor afirma que a "Geografia, a História e a Organização Social e Política do Brasil adquirem tanto mais sentido e vigor quanto mais se interpenetram com vistas à integração do aluno ao meio próximo e remoto" (p. 400).

As concepções curriculares e ontológicas apresentadas anteriormente adquirem ainda mais nitidez com a LDB de 1971. A Geografia, subsumida aos Estudos Sociais, tem sua contribuição bem determinada ao projeto de país pensado pelas lideranças autoritárias e, por conseguinte, o currículo não deixa margem para outras interpretações. O espaço é basicamente compreendido em sua dimensão territorial, base física da pátria, cabendo conhecê-lo e admirá-lo, em suas riquezas naturais e construções humanas, para ser um bom cidadão. Do mesmo modo, ao conhecê-lo é fundamental saber como protegê-lo para o bem do país e das gerações futuras, mantendo intactos os valores morais e religiosos que estruturam a sociedade brasileira. Os sujeitos cognoscentes, não apenas naquele período, mas desde antes, são submetidos a uma grande variedade de conhecimentos, que se anteriormente visavam exclusivamente a preparação erudita dos futuros dirigentes, agora servem também para formar o bom cidadão obediente, disposto ao trabalho e patriota.

A reflexão que nos propomos a realizar em torno da constituição ontologicamente estranhada dos sujeitos cognoscentes vem revelando que o currículo escolar de Geografia historicamente foi construído a partir de uma tentativa de afastamento dos sujeitos em relação às questões espaciais, ou seja, até este momento o que podemos observar é um emaranhado de conhecimentos justapostos apontando apenas para o reconhecimento da realidade fenomênica. 
Destarte, o currículo escolar de Geografia assegurou a cisão cartesiana entre sujeito e objeto através de uma ampla listagem de conhecimentos a serem apresentados e, no momento seguinte, absorvidos. Assim, o ato de "estudar Geografia" consiste em uma observação de uma constelação de informações que muito pouco revelavam sobre o espaço, afastando os sujeitos de um conhecimento mais apurado da dinâmica espacial, sugerindo uma experiência ontológica apartada entre espaço e o homem. É preciso retomar as considerações elaboradas no capítulo anterior para percebermos que o currículo escolar de Geografia opera segundo a premissa cartesiana de que nenhum corpo é espacial, apenas está no espaço, bem como somente o ente homem é existência. Moreira (2015) nos ajuda nesta difícil tarefa argumentativa ao afirmar que se o corpo e eu são encarados como reais separados,

\begin{abstract}
Desdobrados na separação entre espírito e matéria, mente e corpo, homem e natureza tornam-se filosofia consolidada, legitimando a relação entre sujeito e objeto - o eu e o espaço distintos, que o cogito cartesiano institui como ideia de relação homem e mundo em termos de espaço. E por força desse entendimento consolida-se como real uma relação de recíproca externalidade em que o espaço é externo ao homem e o homem é externo ao espaço e apenas nele ocupa um lugar, que a física newtoniana vai instituir como relação continente e conteúdo com seus conceitos de espaço absoluto e espaço relativo e que hoje está na base de toda a visão da geografia. (p. 134)
\end{abstract}

Por conseguinte, entendemos ser indispensável o raciocínio defendido por Carlos (2015) de que o espaço, enquanto categoria do pensamento e realidade prática, traz em si a ideia de referência para o ser humano, uma vez que é sua condição de existência, assim como as transformações da sociedade trazem como consequência modificações espaciais.

A clássica retórica de um estudo enfadonho, mnemônico, de muita pouca relação com a realidade discente nos parece incompleta se não registramos que o currículo escolar de Geografia não abordou o espaço em sua própria dinâmica, mas apenas apresentou informações sobre as suas manifestações visíveis, perspectiva que se manteve inalterada até o período estudado. Destacamos as profícuas palavras de Lima (2013) que corroboram nossa perspectiva e nos permitem seguir em frente:

O espaço cujo sentido deriva da corporeidade dos atores sociais implicados na trama de fenômenos geográficos, ou seja, o espaço geográfico propriamente dito, situa-se entre os domínios do conhecimento e da ontologia, pois é na realidade 
mesma em que reside um significado indeterminado cujo desvelamento na experiência corpórea de espacialidade acarreta em agregação de valor ao conhecimento. (p. 163)

\subsection{A redemocratização e a Geografia crítica}

O fim do período ditatorial civil-militar ocorreu oficialmente em 1985 com a ocorrência de eleições indiretas para presidente, no entanto esse processo transitório tem início ainda na década de 1970 com ascensão do General Ernesto Geisel em 1974 à presidência da República. Os agudos problemas econômicos decorrentes, em grande medida, do esgotamento do chamado "milagre econômico" 82 estimularam o início de um processo de abertura "lenta, gradual e segura”. O grande objetivo do governo Geisel foi efetivar uma transição de abertura totalmente controlado, suprimindo paulatinamente os instrumentos de exceção e retomando progressivamente seu processo de institucionalização sem que revanchismos ameaçassem os militares em seu retorno aos quarteis.

Conquanto esse processo não tenha ocorrido harmoniosamente e que diversos setores militarem tenham resistido (violentamente) ao processo de abertura, é inegável a gradativa retomada da vida democrática, como o aumento dos movimentos sindicais e o fim da censura prévia no rádio e na televisão. João Batista Figueiredo assumiu a presidência (1979) em meio a um agravamento da crise econômica e pressionado pelo fortalecimento dos movimentos contestatórios políticos e civis.

No início da década de 1980 proliferaram os movimentos em defesa do retorno das eleições diretas, contando com a mobilização de amplos setores da sociedade que se manifestavam em comícios, passeatas, produções artísticas etc. A rejeição à emenda Dante de Oliveira, que restabelecia a votação direta para presidente, foi um duro golpe, todavia é preciso registrar a forte presença de diversos setores da sociedade brasileira na luta pelas "Diretas já". Assim, ainda que

\footnotetext{
82 O período compreendido entre 1968 e 1973 é conhecido como "milagre econômico" em virtude do grande desenvolvimento registrado pela economia brasileira. Ao longo daqueles anos a economia do país alcançou taxas de crescimento superiores a $9 \%$ ao ano graças aos grandes investimentos estatais de expansão na oferta de alguns serviços, como energia e telecomunicações. Os investimentos foram originados pela captação de recursos no exterior, elevando a dívida externa.
} 
a emenda tenha sido derrotada no Congresso, a mobilização popular propiciou as condições políticas necessárias para que a chapa de oposição ao governo (Aliança Democrática), encabeçada por Tancredo Neves, fosse vitoriosa, derrotando o governista Paulo Maluf. A morte de Tancredo levou à presidência o vice José Sarney, político experiente e envolvido com os militares.

No campo econômico, o fracasso do Plano Cruzado e dos planos seguintes, demonstravam a complexidade da crise econômica brasileira, bem como a inépcia do Estado em resolvê-la. A "Nova República" assistiu a uma verdadeira ciranda financeira, com inflação descontrolada corroendo o poder de compra da população, e uma situação de estagnação na produção industrial e de baixo crescimento econômico.

Foi no governo Sarney, mais precisamente em 1988, que ocorreu a promulgação de nossa última Constituição. A Carta Magna, que veremos apenas brevemente, considerando nossos objetivos, colocou a educação sob uma perspectiva política e de interesse público, na realidade um direito social como prescrito no art. $6^{83}$ :

Art. $6^{\circ}$ São direitos sociais a educação, a saúde, o trabalho, o lazer, a segurança, a previdência social, a proteção à maternidade e à infância, a assistência aos desamparados, na forma desta Constituição.

Piletti \& Piletti (1995) asseveram que, em linhas gerais, foram incorporados ao texto constitucional os objetivos atribuídos ao ensino de $1^{\circ}$ e de $2^{\circ}$ graus da Lei 5.692/71. Ao observamos com atenção o art. 205 resta explícita a menção ao dever da família e à colaboração da sociedade, eximindo o Estado de um dever exclusivo:

Art. 205. A educação, direito de todos e dever do Estado e da família, será promovida e incentivada com a colaboração da sociedade, visando ao pleno desenvolvimento da pessoa, seu preparo para o exercício da cidadania e sua qualificação para o trabalho.

${ }^{83}$ Disponível em: http://www.planalto.gov.br/ccivil 03/constituicao/constituicao.htm Acessado em: 27/09/2021. Convém mencionar que a emenda constitucional $\mathrm{n}^{\circ} 90$, de 2015 , alterou o art. 6 para a seguinte redação: São direitos sociais a educação, a saúde, a alimentação, o trabalho, a moradia, o transporte, o lazer, a segurança, a previdência social, a proteção à maternidade e à infância, a assistência aos desamparados, na forma desta Constituição. 
Outro aspecto fundamental a ser mencionado reside no art. 206, que aponta os princípios que regem a educação do país a partir de então:

Art. 206. O ensino será ministrado com base nos seguintes princípios:

I - igualdade de condições para o acesso e permanência na escola; II - liberdade de aprender, ensinar, pesquisar e divulgar o pensamento, a arte e o saber;

III - pluralismo de idéias e de concepções pedagógicas, e coexistência de instituições públicas e privadas de ensino;

IV - gratuidade do ensino público em estabelecimentos oficiais;

V - valorização dos profissionais do ensino, garantido, na forma da lei, plano de carreira para o magistério público, com piso salarial profissional e ingresso exclusivamente por concurso público de provas e títulos, assegurado regime jurídico único para todas as instituições mantidas pela União;

VI - gestão democrática do ensino público, na forma da lei;

VII - garantia de padrão de qualidade.

Os avanços identificados neste artigo são dignos de nota por preconizarem, de forma inédita, a "permanência na escola", o "pluralismo de ideias e de concepções pedagógicas", a "valorização dos profissionais do ensino", a "gestão democrática", princípios até então distantes da realidade educacional do país. Destarte, na letra fria da lei, a educação, enquanto direito social, é oferecida a partir de princípios que têm por escopo propiciar ao cidadão o acesso ao conhecimento sem qualquer distinção, bem como permitir a sua autonomia pelo acesso aos saberes.

Em suma, portanto, é possível afirmar que até 1988 não havia uma preocupação real em criar mecanismos que fossem eficazes na garantia do direito à educação. Durante muito tempo a única ação do Poder Público foi tornar obrigatória a matrícula escolar, como se isto fosse suficiente para garantir a educação. Todavia, não podemos perder de vista que este documento sustenta um Estado burguês, ou seja, um Estado que articula sua superestrutura jurídico-política em favor da sociedade burguesa através da coerção e do consentimento. Esta consideração é fundamental para pensarmos a temática educacional em qualquer período da história nacional, como no período em tela, em que é possível perceber a educação funcionando em razão da consolidação da política econômica desenvolvida no Brasil ao final do século XX. Esta análise prescinde dos apontamentos a serem feitos sobre a LDB de 1996. 
A Lei 9394/96 institui a nova Lei de Diretrizes e Bases da Educação Nacional, que, entre outras atribuições, determinou que a União em colaboração com Estados e Municípios deveriam estabelecer as diretrizes para a Educação Básica, que nortearão os currículos e seus conteúdos mínimos de forma a assegurar a formação básica comum (Art. 9). Por conseguinte, são formulados pelo Ministério da Educação e Cultura (MEC) documentos oficiais de orientação curricular, cuja finalidade não se limita apenas em definir os conteúdos a serem trabalhados pelas escolas do país, mas também constituem base para a avaliação da educação nacional.

A LDB/96 consagrou o ensino médio como etapa final da educação básica, atribuindo identidade ao segmento, mesmo que não tenha assegurada a sua obrigatoriedade. O ensino médio, segundo a LDB/96, com duração mínima de três anos, tem as seguintes finalidades:
Art. 35. O ensino médio, etapa final da educação básica, com duração mínima de três anos, terá como finalidades:
I - a consolidação e o aprofundamento dos conhecimentos adquiridos no ensino fundamental, possibilitando o prosseguimento de estudos;
II - a preparação básica para o trabalho e a cidadania do educando, para continuar aprendendo, de modo a ser capaz de se adaptar com flexibilidade a novas condições de ocupação ou aperfeiçoamento posteriores;
III - o aprimoramento do educando como pessoa humana, incluindo a formação ética e o desenvolvimento da autonomia intelectual e do pensamento crítico;
IV - a compreensão dos fundamentos científico-tecnológicos dos processos produtivos, relacionando a teoria com a prática, no ensino de cada disciplina.

Ao longo do tempo, como podemos perceber após toda a explanação, o ensino médio se constituiu como uma etapa de formação profissional, com grande destaque para a preparação à entrada no ensino superior. Por conseguinte, segundo Silva (2016), é possível vislumbrar uma espécie de encruzilhada vivida por esse segmento: ou prepara os estudantes para a vida em sociedade, aprofundando seus conhecimentos sobre o funcionamento do mundo e das coisas, ampliando seu capital cultural, temporalidades, espacialidades, evolução dos conhecimentos etc.; ou prepara para o mundo do trabalho, atento ao mercado de trabalho desejoso por trabalhadores flexíveis, com habilidades inerentes à competição global; ou ainda treina os estudantes para as provas e testes de ingresso ao ensino superior. São estas 
questões que interferem diretamente na organização dos currículos, dos tempos e espaços escolares, bem como nas práticas pedagógicas docentes, como métodos avaliativos e estratégias didáticas.

Em meio a essas questões, foram elaborados alguns documentos oficiais que reformaram o campo educacional, como os Parâmetros Curriculares Nacionais para o Ensino Médio (PCNEM) e as Diretrizes Curriculares Nacionais para o Ensino Médio (DCNEM), todos documentos regidos pela LDB/96. É evidente o movimento do Estado no sentido de proporcionar um processo de reformulação curricular, processo esse iniciado com a LDB/96 e que ganhou ainda mais concretude com a publicação destes documentos e de alguns pareceres complementares. Portanto, nosso estudo optou por não priorizar nenhum dos documentos porquanto ambos consistem em documentos oficiais de referência para a construção dos currículos, fato que nos impele a tomá-los como objeto de reflexão mais aprofundada.

Um estudo adequado desse movimento de reorientação curricular de Geografia para o ensino médio demanda a consideração do contexto acadêmico vivido pela ciência geográfica brasileira até meados da década 1990, uma vez que os documentos adotam uma perspectiva teórica bastante alinhada com o período científico em voga. Diante desta situação se faz necessário retomarmos a argumentação acerca do processo de constituição do pensamento geográfico, especialmente a etapa iniciada em meados da década de 1970 e que reverbera até hoje no contexto acadêmico e escolar nacional.

Naquela década emergiu uma outra vertente de renovação do pensamento geográfico em oposição às Geografias existentes, recebendo esta denominação em virtude de seu posicionamento crítico radical frente à Geografia Moderna e Teorética. Conforme salienta Moraes (2005), a perspectiva "crítica" advém da postura política adotada, em que os autores "se posicionam por uma transformação social, pensando o seu saber como uma arma desse processo" (p. 119). Não obstante, estes pensadores assumem a impossibilidade de um conhecimento neutro ao denunciarem o conteúdo político presente nas ciências e defendem uma análise geográfica em prol da libertação do homem (Idem). 
É fundamental termos em mente, segundo estudo de Carlos (2015), que a constituição de um saber geográfico, de suas formas de interpretação da realidade, da elaboração de teorias se move num contexto histórico-social, "o que significa dizer que as mudanças nos modos de pensar a Geografia são produto direto das transformações da realidade e da inserção do conhecimento no movimento do mundo e de seu conhecimento" (p. 22).

A observação mais atenta desta corrente nos revela os fundamentos filosóficos que sustentaram estas transformações e que são de grande relevância para o restante da discussão. Com efeito, Gomes (1996) identificou dois grupos de críticas à Geografia: uma de caráter teórico-metodológico e outra relacionada ao domínio prático e ideológico. O primeiro grupo corresponde a um exercício de desaprovação às ideias sustentadas pelo modelo econômico neoliberal, de onde seria possível desenvolver um comportamento social plenamente racional, ou seja, uma conduta que, em geral, "busca a satisfação máxima de suas necessidades a partir de uma via analítica, racional e objetiva" (p. 275). Estes modelos privilegiam uma expectativa de concorrência perfeita, difusão igualitária de informações e um espaço isomórfico, ou seja, são expectativas que revelam uma profunda abstração teórica e suscitou um apelo à consideração dos condicionantes materiais.

O segundo grupo reuniu diversas críticas à ideia de que a Geografia deveria “intervir na realidade, capaz de dar respostas objetivas, neutras e justas aos problemas sociais", de maneira que houve forte contestação a forma de participação da Geografia nos planos de gestão territorial porquanto "foi interpretada como sendo tão-somente uma tentativa de preservar o status quo" (Idem. p. 277). Em suma, a crítica residiu no entendimento de que

A ciência é o produto de uma sociedade desigual, na qual o poder é exercido por grupos minoritários que controlam também a produção do saber, seus objetivos e aplicações. O discurso da objetividade é, portanto, construído sobre aparências e tem como objetivo fundamental reproduzir e justificar "cientificamente" as estruturas do poder e os prestígios sociais já constituídos. (Ibidem).

Neste sentido, os autores imbuídos dessas ideias não se limitaram a um questionamento formal do pensamento tradicional ou quantitativo, mas exigiram a crítica do empirismo exagerado presente na Geografia Moderna, que acorrentou 
todas as análises às aparências, como também contestaram todas as decorrências da fundamentação positivista (MORAES, 2005). De forma mais aprofundada os fundamentos da crítica radical consistem, basicamente, por um lado, na desaprovação da ideia de que o homem é essencialmente racional - perspectiva que remete diretamente ao pensamento ontológico cartesiano -, uma vez que a generalização da racionalidade desconsidera os contextos históricos e a inscrição dos indivíduos em suas classes sociais, criando uma noção abstrata desvinculada do real. Este outro posicionamento metodológico registra "a diferença entre um procedimento que parte de uma idealização, para compreender a realidade, e outro que parte da realidade material", ou mais precisamente a oposição entre "uma ciência idealista e ideológica a um verdadeiro conhecimento histórico-materialista" (GOMES, 1996. p. 277).

Por outro lado, está a constatação do positivismo como demonstração da ciência burguesa por legitimar o exercício desigual do poder e do controle social (Ibidem). Frigotto (2014) afirma tratar-se da "ciência burguesa", "mediada pela ideologia que naturaliza as relações capitalistas, centra-se no entendimento de suas funções e disfunções internas e ignora o que historicamente a produz". (p. 34), conferindo um ar de eternidade e inevitabilidade do capitalismo. Neste sentido, fica nítida a intenção de transmitir a ideia de eternidade inevitável do capitalismo através de duas operações:

\footnotetext{
Mascarando a especificidade e a profundidade da crise do capital e sua violência na destruição de direitos [...]; e afirmando os horizontes ético-políticos utilitaristas que sustentam o ideário do mercado autorregulado como parâmetro das relações sociais e impõem a ditadura da razão única - a razão do capital. (Idem. p. 35)
}

Segundo nossa compreensão, e já fazendo uma aproximação com o encerramento deste capítulo, esta perspectiva de perenidade capitalista é perpassada em grande medida pela forma como a categoria trabalho é abordada pelo currículo escolar, inclusive sob o predomínio da Geografia crítica. Na realidade, percebemos que o trabalho sempre figurou entre diferentes conteúdos, desde discussões relacionadas à ação humana sobre a natureza até as revoluções industriais, todavia seu caráter dialético não é contemplado, ou seja, o currículo escolar não desenvolve a ideia de que ao transformar a natureza (ou o espaço) o homem também transforma 
a si mesmo, condição que o torna inexoravelmente em ser social da produção do espaço e de si mesmo. Outrossim, o trabalho é entendido apenas como uma atividade laboral para a sobrevivência, mascarando seus aspectos essenciais relacionados ao próprio sujeito. Por conseguinte, os estudantes não se percebem produtores de mercadorias (aqui incluindo também o espaço) e produtores de si mesmo, consubstanciando uma relação estranhada com a natureza. Avançaremos ainda mais nesta discussão a partir da observação das considerações de um importante autor francês bastante crítico da Geografia.

Lacoste (2012) é considerado um dos principais expoentes daquele período de renovação por elaborar uma crítica bastante radical à ciência geográfica. Vesentini, na apresentação da referida obra, afirma que seu pensamento acompanha a corrente teórica daqueles que recusam

A supervalorização de sistemas e conceitos, que procuram apreender o real em seu movimento - com a ajuda de textos clássicos, inclusive de Marx, mas sem mitificá-los -, o que vale dizer que esse real não é tomado como pretexto para se ilustrar a teoria "revolucionária" já pronta, mas sim que sua natureza "viva" ou histórica determina uma recriação constante das expressões teóricas. (p. 12)

A menção a Marx feita por Lacoste sugere a grande influência que o pensamento marxista exerceu nas ciências humanas, destacadamente na segunda metade do século XX. Marx produziu um saber objetivo e racional guiado pelo método materialista-histórico, ao qual já fizemos referência anteriormente. No entanto, é interessante ressaltarmos apenas que do prisma marxista, a realidade é alcançada por intermédio da razão, que permite reconhecer, no interior do caos da sociedade, os fatores fundamentais de sua organização e de seu desenvolvimento. O pensamento de Marx encontrou forte penetração na crise vivida pela Geografia por questionar certezas até então inquestionáveis, como a compreensão do real. Mais uma vez, recorremos a Gomes (2006) para explicar que

Marx introduz a noção de uma razão histórica, materialmente determinada, em oposição à concepção do idealismo que definia o real como um produto da razão absoluta. Desta maneira, o marxismo afirma que o sujeito do conhecimento, historicamente determinado e contextualizado socialmente, é capaz de ser apreendido pela ciência a partir das categorias essenciais que o envolvem: a produção, a reprodução, o consumo, a troca, a propriedade, o Estado, o mercado e as classes sociais. (p. 282) 
Ao refletir sobre a relação entre marxismo e Geografia, Moreira (2004) identifica dois momentos, o primeiro ocorreu no imediato pós-guerra com os geógrafos franceses da chamada Geografia ativa, e o segundo se deu nos anos 1970, reunindo desde ativistas da revista Antípode da "geografia radical" até os geógrafos brasileiros da corrente crítica. Assim, as temáticas do marxismo e a renovação da Geografia em curso no Brasil ${ }^{84}$ se cruzaram, trazendo à tona outras interpretações e discussões para o seio da ciência, tais como as noções de concretude histórica dos fenômenos ou de relação homem-meio como uma relação metabólica passada entre o homem e a natureza. Todavia, Moreira (2015) faz importante ressalva ao assinalar que

Se um inédito processo de refundição marxista ocorre por dentro da renovação da geografia, a renovação, todavia, não se confunde com o marxismo e os geógrafos de formação marxista. Até porque, verdadeiramente, o que há é um movimento plural, convergente apenas no que toca ao descontentamento, a todos comum, que existe em relação ao discurso geográfico vigente. (p. 29)

Atentos a este alerta é possível progredir em nossa análise e se torna fundamental observar que diversas mudanças estavam ocorrendo e modificando a realidade circundante. A internacionalização industrial, a rede global de comunicações, a crescente evolução tecnológica, o processo de descolonização, as transformações na divisão internacional do trabalho, enfim a reprodução em escala ampliada das relações capitalistas de produção mostra como a introdução do pensamento marxista foi marcante e adequada para erigir uma outra forma de interpretação e de investigação da realidade. Destarte, o marxismo provocou uma retificação dos trabalhos acadêmicos, enquadrando-os numa visão mais ampla e consciente do contexto político da ciência e da sociedade, como também possibilitou às ciências humanas desenvolverem modelos teóricos inteiramente concebidos na esfera do domínio social, interrompendo a predominância dos modelos das ciências naturais (GOMES, 2006).

\footnotetext{
${ }^{84}$ No caso brasileiro foi bastante emblemático o $3^{\circ}$ Encontro Nacional de Geógrafos (ENG) realizado em Fortaleza (CE) no ano de 1978. Moreira (2015) afirma que aquele Encontro ensejou "o olhar recíproco, o conhecimento dos protagonistas uns dos outros, a conscientização dos descontentamentos que promovem a necessidade das mudanças e a aglutinação das ideias que precipitam a crise da ciência" (p. 24).
} 
Ao relacionarmos a estruturação deste novo paradigma científico com nossos objetivos chegamos até uma outra contribuição de Lacoste, apontada para podermos investigar as novas orientações curriculares. Foi este autor progressista francês que denunciou a existência de dois planos de manifestação do saber geográfico: o primeiro é mais antigo, datando do final do século XIX, chamado de "geografia dos Estados-maiores" que consiste basicamente num "conjunto de representações cartográficas e de conhecimento variados de representações cartográficas e de conhecimento variados referentes ao espaço", sendo um valioso instrumento de poder restrito a um grupo minoritário. (Idem. p. 31)

O segundo é mais recente e é chamado de "geografia dos professores", que representa "um discurso ideológico no qual uma das funções inconscientes, é a de mascarar a importância estratégica dos raciocínios centrados no espaço" e foi transformado, inicialmente na França e na Alemanha, em um "discurso pedagógico de tipo enciclopédico, como discurso científico" que se sustenta em procedimentos de "enumeração de elementos de conhecimento mais ou menos ligados entre si pelos diversos tipos de raciocínios", cuja finalidade é uma só: "mascarar sua utilidade prática na conduta da guerra ou na organização do Estado" (Ibidem).

A crítica de Lacoste aponta para o caráter de classe da Geografia, enfatizando-a como um instrumento de dominação burguesa, dotado de um alto potencial prático e ideológico. Em suma, a Geografia Crítica incide sobre os compromissos sociais e nos posicionamentos políticos da ciência, prescrevendo uma ruptura com as correntes geográficas anteriores e a construção de um conhecimento diametralmente oposto às propostas de Geografia anteriores. Por conseguinte, o espaço social, construído, fruto da humanização da natureza, não pode mais ser entendido e ensinado como um elemento inerte a espera da apropriação humana, como apregoaram tanto a Geografia moderna como a "dos professores".

Foi em meio a esse controverso e turbulento período de crises que emergiu uma profunda insatisfação de geógrafos e professores com sua disciplina e com a longa permanência de seu caráter descritivo e mnemônico, compartimentado entre, de um lado, as questões da "natureza" e, de outro lado, as temáticas "humanas", abordando assuntos "gerais" e posteriormente temas "regionais". Coerente com esta crítica, entendemos que o marxismo pode oferecer um caminho de superação da 
dicotomia homem-natureza, à medida que demonstra como esta separação entre o homem e as condições naturais de sua existência é um produto histórico e mediado pela categoria trabalho. Este caminho é justamente a filosofia da práxis, que, como já apresentamos, enfatiza o sentido original da práxis, do agir humano em sua dimensão ontológica, pondo luz na vinculação inextricável entre o ser e o conhecimento, ou seja, a categoria trabalho nos permite redirecionar a perspectiva curricular original para o desenvolvimento de uma proposta, mais próxima da proposta gramsciana. O próprio Gramsci (2015) nos ensina que

Uma filosofia da práxis só pode apresentar-se, inicialmente, em atitude polêmica e crítica, como superação da maneira de pensar precedente e do pensamento concreto existente (ou mundo cultural existente). E portanto, antes de tudo, como crítica do "senso comum" (e isto após basear-se sobre o senso comum para demonstrar que "todos" são filósofos e que não se trata de introduzir ex novo uma ciência na vida individual de "todos", mas de inovar e tornar "crítica" uma atividade já existente); e, posteriormente, como crítica da filosofia dos intelectuais, que deu origem à história da filosofia e que, enquanto individual (e, de fato, ela se desenvolve essencialmente na atividade de indivíduos singulares particularmente dotados), pode ser considerada como "culminâncias" de progresso do senso comum, pelo menos do senso comum dos estratos mais cultos da sociedade e, através desses, também do senso comum popular. (p. 81)

Ao pensarmos esta questão pelo prisma da Geografia, asseveramos que o homem e sua relação com o espaço precisam ser humanizados e entendemos, apoiados pelo pensamento de Carlos (2015), que é a perspectiva apresentada por Marx (e por Gramsci) na práxis que permite pensar o mundo enquanto prática, enquanto processo de transformação de si mesmo, pensar tanto o sujeito quanto a sociedade realizando-se, "um entendimento sobre o espaço como conceito teórico e como realidade concreta" (p. 28).

São estas considerações de cunho ontológico-gnosiológico que manteremos em mente para analisarmos e interpretarmos os documentos que balizam o ensino de Geografia para o ensino médio com a certeza de que esta disciplina escolar pode colaborar para a construção de uma outra relação dos sujeitos com o espaço e, consequentemente, consigo mesmos. 


\subsection{Currículo de Geografia em tempos neoliberais}

A devida compreensão deste período evidentemente reclama algumas considerações acerca do ideário neoliberal, entendido a partir de um processo desigual e descontínuo de constituição de uma sociedade neoliberal, segundo proposição de Dardot \& Laval (2014). Para estes autores, estamos diante de "um processo histórico que não foi integralmente programado por seus pioneiros; os elementos que a compõem reuniram-se pouco a pouco, interagindo uns com os outros, fortalecendo uns aos outros" (p. 24). Antes de progredimos nestas considerações cabe ressalvar o distanciamento de uma prolongada discussão teórica acerca do neoliberalismo, tanto em sua dimensão político-ideológica quanto econômica, posicionamento adotado com vistas a não marginalizarmos os objetivos apresentados.

Os autores supracitados nos servem de parâmetro teórico-conceitual para fundamentar nossa breve discussão acerca do neoliberalismo justamente por defenderem sua compreensão enquanto uma racionalidade governamental, e não uma doutrina mais ou menos heteróclita, isto é, o neoliberalismo consiste no desenvolvimento da lógica do mercado como lógica normativa generalizada, desde o Estado até o mais íntimo da subjetividade (Idem). Especialmente a partir dos de 1980, o Ocidente foi marcado pelo triunfo de uma política qualificada, ao mesmo tempo, de "conservadora" e "neoliberal". Os principais líderes mundiais daquele período, Ronald Reagan e Margaret Thatcher, simbolizam uma brusca ruptura com o "welfarismo" da socialdemocracia e a adoção de um novo conjunto de políticas voltadas a superação da inflação galopante, da queda dos lucros e da desaceleração do crescimento. A política conservadora e neoliberal adquiriu contornos de resposta ou solução política à crise econômica e social do regime "fordista" de acumulação do capital.

Estas políticas neoliberais têm como principal aspecto a radical alteração do modo de exercício do poder governamental, assim como as referências doutrinais no interior de uma ampla transformação das normas capitalistas. Ademais, revelam uma subalternização a um certo tipo de racionalidade política e social articulada à globalização e à financeirização do capitalismo (Idem). Nestes termos, se o compromisso da socialdemocracia estava relacionado ao intervencionismo do 
Estado, a proposta neoliberal está voltada ao livre mercado, o que também significa pôr em destaque o seu caráter disciplinar. É este caráter disciplinar que

Dá ao governo um papel de guardião das regras jurídicas, monetárias, comportamentais, atribui-lhe a função oficial de vigia das regras de concorrência no contexto de um conluio oficioso com grandes oligopólios e, talvez mais ainda, conferelhe o objetivo de criar situações de mercado e formar indivíduos adaptados às lógicas de mercado. (Idem. p. 189, grifos nossos)

Por consequência, é possível perceber que as políticas neoliberais guardam uma dimensão estratégica que permaneceu negligenciada pela "crítica "antiliberal" padrão, uma vez que essa dimensão entra de imediato numa racionalidade global que permaneceu despercebida. Esta ideia de "racionalidade neoliberal" nos é bastante cara porque é justamente onde entendemos residir todo o processo de reordenação curricular e de construção dos documentos curriculares oficiais, ou seja, estamos direcionando nossa argumentação para o interior da racionalidade neoliberal porque é neste terreno que reside todo o arcabouço teórico e político do projeto de formação dos sujeitos a partir dos currículos desenvolvidos pelo Estado burguês.

A abordagem do neoliberalismo se desdobra sobre os mesmos preceitos teóricos marxistas que temos sustentado desde o início da pesquisa e que revelam algo fundamental: a criação de um "novo conjunto de regras que definem não apenas outro 'regime de acumulação', mas também, mais amplamente, outra sociedade" (Ibidem). Esse movimento em torno de um outro "regime de acumulação" e de uma "outra sociedade" só é possível com a formação de outros sujeitos cognoscentes, preparados para as novas exigências do mercado, mas que mantenham a mesma relação estranhada de outrora com a natureza para garantir o fetichismo da mercadoria e a reificação das relações humanas. Destarte, o currículo escolar precisa estar prenhe de ideias, discursos, objetivos que mantenham o trabalho, enquanto ato de transformação humana da natureza, como uma mera atividade de todo cidadão, escamoteando suas nuances ontológicas, tarefa que já vem sendo desempenhada. O que assistimos é a nossa relação social com as atividades laborais dos outros serem dissimuladas em relações entre coisas. Esta constatação, em nosso entender, é oriunda, em alguma medida, do currículo escolar 
de Geografia que não desperta a consciência para a variedade de condições sociais, interligações espaciais e práticas laborais que envolvem toda a vida cotidiana.

Anteriormente já havíamos feito menção à categoria trabalho e o progresso da pesquisa torna indispensável reconsiderar este tema para que possamos compreendê-lo ontologicamente no seio do neoliberalismo. Partimos do princípio de que o neoliberalismo promoveu uma repactuação social com vistas a garantir a acumulação de capital através de uma série de transformações produtivas e de rearranjos institucionais, o que significa que os preceitos do trabalho, assim como explicado por Marx, não são alteradas pelo modo de produção capitalista. Por conseguinte, no interior das instituições que dão suporte ao modo de produção capitalista, algumas transformações são efetivadas, mas a reprodução da categoria "trabalho" pelo currículo escolar permanece intacta, ainda que sob outros conteúdos, no interior da nova racionalidade neoliberal.

Em suma, os sujeitos cognoscentes se tornarão trabalhadores e trabalharão para outros de forma a viabilizar a produção dos valores de troca de mercadorias, que geram o retorno monetário sobre o qual o capital constrói seus poderes sociais de dominação de classe (HARVEY, 2016). Nesta situação, e aqui reside um ponto fundamental, os trabalhadores estão colocados numa posição de subalternização em que só podem reproduzir pelo trabalho as condições de sua própria dominação. Portanto, acreditamos que a abordagem fenomênica da categoria trabalho pelo currículo escolar, em tempos de racionalidade neoliberal, colabora para o desenvolvimento de uma relação estranhada entre os sujeitos cognoscentes e o espaço, uma vez que esta categoria é essencialmente intermediária, é o vínculo material e objetivo entre ser humano (sujeito) e natureza (espaço).

De posse destas premissas, nossa abordagem demanda, a partir deste momento, que consideremos o contexto político-educacional que circundou as iniciativas de reordenação curricular nacional, o que permitirá que examinemos as questões propriamente curriculares de forma mais adequada. Destarte, é importante pontuar que todos os documentos de reorientação curricular estão inseridos num amplo movimento de renovação curricular dos países em desenvolvimento ocorrido em fins da década de 1990 a partir de um projeto financiado pelo Banco Mundial. 
A condução desse processo coube ao Governo Federal, presidido por Fernando Henrique Cardoso, tendo como agente central o Ministério da Educação, liderado por Paulo Renato de Souza. A finalidade mais ampla daquele projeto foi a adequação do sistema de ensino nacional a um conjunto de medidas definido pelas diretrizes do Fundo Monetário Internacional e pelo próprio Banco Mundial. Já neste princípio é possível perceber como a influência política e econômica de organismos financeiros internacionais estipularam a maneira como o Brasil deveria reorganizar os seus parâmetros educacionais, situação que Vesentini (edições Kindle, sem datação) identificou como uma estratégia de preparo de "qualificação da mão de obra" ao escrever que

Desde no mínimo 1990 que o Banco Mundial só concede novos empréstimos aos países "em desenvolvimento" com a condição de existirem investimentos na educação e na melhor qualificação da mão de obra. E o programa do Pnud das Nações Unidas, que desde 1990 estipula o Índice de Desenvolvimento Humano (IDH) de 174 países, já passou a incorporar como elementos básicos para calcular esse índice as taxas de escolaridade (masculina e feminina), o acesso da população em geral ao ensino elementar, ao ensino secundário etc. [...] Isso sem contar aquele famoso estudo patrocinado pela Unesco ${ }^{85}$, que contou com a colaboração de dezenas de educadores de inúmeras partes do mundo e exerceu enorme influência em várias novas propostas de reformulação curricular em países da América Latina, da África e da Ásia (inclusive os PCNs do Brasil), no qual os conteúdos das disciplinas escolares são minimizados e o fundamental passa a ser o "aprender a aprender, a ser, a conviver com os outros, a fazer".

Este ponto de partida é relevante porque demonstra como nossa posição divisão internacional do trabalho colocou grande pressão sobre o Estado para a promoção de uma reorganização escolar que permitisse a formação de uma nova mão de obra consoante à Terceira Revolução Industrial, que exige trabalhadores qualificados e flexíveis. Nesta seara é inevitável explicitarmos, ainda que brevemente, o desenvolvimento de um novo modelo de acumulação flexível e de seu momento predominante, o toyotismo. Alves (2005) afirma que no atual momento histórico de mundialização do capital e de profundas transformações produtivas, em que há mutações em curso de implicação subjetiva nas instancias do trabalho e da reprodução social, o toyotismo é a "ideologia orgânica da produção

\footnotetext{
${ }^{85}$ Este "famoso estudo" será melhor apresentado logo a frente.
} 
capitalista, que tende a colocar novas determinações nas formas de ser da produção e reprodução social", ou seja, considerando este novo mundo, densamente configurado pela necessidade de novos sujeitos e subjetividades, o toyotismo é entendido como a "expressão superior da racionalização capitalista nos loci mais dinâmicos da acumulação de valor, exigindo, na etapa desenvolvida do processo civilizatório, uma nova implicação subjetiva [...]" (p. 410).

Em qualquer análise dos processos sociais é fundamental ter em mente uma apreensão dialética da natureza do período histórico de desenvolvimento do capitalismo mundial. Destarte, se nas épocas precedentes, destacadamente os de predomínio do fordismo, havia a captura do corpo e uma relativa liberdade do cérebro para outras ocupações - gerando uma relação problemática corpo-mente (GRAMSCI, 1984 apud ALVES, 2005), no atual período, sob o predomínio da produção toyotista “corpo e mente 'tendem a ser' mobilizados pelo capital para se integrarem a produção de valor" (p. 411).

A crise do mundo capitalista da década de 1970 instaurou um novo regime de acumulação do capital, a acumulação flexível, que tendeu a satisfazer "as exigências do capitalismo mundial, sendo adequado às novas condições de concorrência e de valorização do capital e ao novo patamar da luta de classes na produção" (Idem. p. 413), e compondo sua ideologia orgânica no interior da III Revolução Tecnocientífica a partir do modelo japonês de reorganização produtiva pós-crise estrutural capitalista. Neste sentido, o toyotismo passou a incorporar uma “'nova significação' para além das particularidades de sua gênese sócio-histórica (e cultural), vinculada ao capitalismo japonês", adquirindo como aspecto essencial a expressão em seus dispositivos e protocolos organizacionais “a busca de uma nova hegemonia do capital na produção como condição política (e sócio-cultural) para a retomada da acumulação capitalista, uma hegemonia do capital voltada para realizar uma nova captura da subjetividade do trabalho pela lógica do capital" (Ibidem).

Condizente com esta perspectiva, a Unesco reuniu renomados estudiosos para fazer uma análise da conjuntura educacional no mundo e a partir dos resultados obtidos estabelecer metas pedagógicas a serem seguidas pelos países, incluindo o Brasil. Desta análise saiu um relatório, o "Relatório para a Unesco da Comissão Internacional sobre Educação para o Século XXI", também conhecido como Relatório Delors (em referência ao chefe da comissão, Jacques Delors), que 
defendeu a educação como um agente de transmissão de cada vez mais saberes e "saber-fazer" evolutivos e serviu de fundamento para a redação dos novos documentos curriculares. Destarte, foram apresentados quatro pilares considerados fundamentais e aqui estão sintetizados:

1. Aprender a conhecer: este tipo de saber visa além do saber codificado, vai ao domínio dos próprios instrumentos do conhecimento simultaneamente, como meio e como finalidade humana. Aprender para conhecer supõe um aprender contínuo, um aprender a aprender, exercitando a atenção, a memória e o pensamento em todas as fazes da vida. O processo de aprendizagem nunca está completo e enriquece com qualquer experiência;

2. Aprender a fazer: aprender a fazer em algum momento se aproxima do aprender a conhecer, mas está mais ligada à questão da formação profissional. Neste item, a noção de competência aparece com destaque substituindo a qualificação. Este saber fazer não está ligado diretamente a uma questão específica, mas para uma realidade moderna

3. Aprender a viver juntos, aprender a viver com os outros: principal desafio da educação no mundo atual em decorrência da própria história humana ser sempre marcadas por conflitos e violências. A busca pela coexistência pacífica entre povos e culturas é o desafio do momento presente.

4. Aprender a ser: todo ser humano deve estar preparado, graças à educação que recebe na juventude para elaborar pensamentos autônomos e críticos e para formular juízos de valor para saber como agir em diferentes momentos da vida. $\mathrm{O}$ aprender a ser deve acompanhar o cidadão em todas as suas atitudes, seja na vida social ou profissional.

Como se vê, há implícito um discurso de homem ideal a ser formado a fim de atender à necessidade do mundo no século XXI: global, total e dinâmico. Estas exigências demandam uma ideia de educação para toda a vida, ou seja, considerando todas as modificações em curso da sociedade, a tecnologia em contínuo e rápido desenvolvimento, as diferentes exigências do mundo do trabalho, as diversidades em franco crescimento e todas as demais situações de novidade que impelem a adaptação do sujeito.

Diante deste contexto é interessante observarmos de forma mais direta os documentos que balizaram a reordenação curricular de Geografia, começando pelos PCNs de Geografia. A organização deste documento destaca a importância da Geografia para as Ciências Humanas na última etapa da educação básica, enfatizando que o ensino de Geografia deve "construir competências que permitam a análise do real, revelando as causas e efeitos, a intensidade, a heterogeneidade e 
o contexto espacial dos fenômenos que configuram cada sociedade" (PCN, 2000.

p. 30). É defendido que os saberes geográficos escolares desenvolvidos pelos estudantes são fundamentais para o desenvolvimento de competências e habilidades, conceitos considerados inovadores do novo currículo, que tem como uma das suas prioridades formar o aluno para o mercado de trabalho do século XXI e que merecem algumas linhas.

Como temos tentado demonstrar, o preparo para o exercício da cidadania e a qualificação para o trabalho consistem nas principais finalidades da educação e despertaram toda uma sorte de transformações para levar a cabo uma melhor formação dos estudantes brasileiros. Destarte, é interessante observarmos um trecho do parecer da Câmara 15/98 de Educação Básica sobre as DCNEM, que explicita alguns parâmetros balizadores desta perspectiva formativa:

A concepção da preparação para o trabalho que fundamenta o Artigo 35 aponta para a superação da dualidade do ensino médio: essa preparação será básica, ou seja, aquela que deve ser base para a formação de todos e para todos os tipos de trabalho. Por ser básica terá como referência as mudanças nas demandas do mercado de trabalho, daí a importância da capacidade de continuar aprendendo; não se destina apenas àqueles já que estão no mercado de trabalho ou que nele ingressarão a curto prazo; nem será preparação para o exercício de profissões específicas ou para a ocupação de postos de trabalho determinados. (p. 14)

A União Europeia manifestou-se de forma contundente a favor da unificação do ensino médio, mas alerta para a necessidade de considerar outras necessidades além das que são sinalizadas pela organização do trabalho. E busca sustentação para sua posição no pensamento do próprio empresariado europeu: a missão fundamental da educação consiste em ajudar cada indivíduo a desenvolver todo o seu potencial e a tornar-se um ser humano completo, e não um mero instrumento da economia; a aquisição de conhecimentos e competências deve ser acompanhada pela educação do caráter, a abertura cultural e o despertar da responsabilidade social. (p. 16, grifos nossos)

Em meio a essas demandas do capital internacional, que exige uma ampla formação dos sujeitos para atender um novo perfil de trabalho, os PCNEM adotaram os conceitos de habilidades e competências. O próprio documento nos informa que

Dentre os quatro princípios propostos para uma educação para o século XXI - aprender a conhecer, aprender a fazer, aprender a conviver e aprender a ser - destaca-se o aprender a conhecer, base que qualifica o fazer, o conviver e o ser e síntese de uma 
educação quem prepara o indivíduo e a sociedade para os desafios futuros, em um mundo em constante e acelerada transformação. A educação permanente e para todos pressupõe uma formação baseada no desenvolvimento de competências cognitivas, sócio-afetivas e psicomotoras, gerais e básicas, a partir das quais se desenvolvem competências e habilidades mais específicas e igualmente básicas para cada área e especialidade de conhecimento particular. (PCN, 2000. p. 11)

Não é nosso intuito divagar acerca destes conceitos, mas, apenas, evidenciar como seu aparecimento está estritamente ligado a um conjunto de transformações bastante intenso no mundo do trabalho, buscando recondicionar toda a organização do ensino médio brasileiro, com objetivos que ainda pretendemos melhor explorar. Para visualizarmos de forma mais aprofundada as nuances que perpassam todo esse período de renovação é interessante ressaltar que as competências são compreendidas enquanto capacidades mais gerais e flexíveis, que permitem enfrentar a variedade de tarefas e tomar, em tempo real, decisões de ação adaptadas a cada contexto particular. Neste sentido, os próprios PCNs estabelecem que as competências esperadas versam acerca

Da capacidade de abstração, do desenvolvimento do pensamento sistêmico, ao contrário da compreensão parcial e fragmentada dos fenômenos, da criatividade, da curiosidade, da capacidade de pensar múltiplas alternativas para a solução de um problema, ou seja, do desenvolvimento do pensamento divergente, da capacidade de trabalhar em equipe, da disposição para procurar e aceitar críticas, da disposição para o risco, do desenvolvimento do pensamento crítico, do saber comunicar-se, da capacidade de buscar conhecimento. Estas são competências que devem estar presentes na esfera social, cultural, nas atividades políticas e sociais como um todo, e que são condições para o exercício da cidadania num contexto democrático. (PCN, 2000. p. 11/12)

Por seu turno, as habilidades decorrem diretamente das competências adquiridas e se referem ao plano imediato do "saber fazer". Por meio de ações e operações, as habilidades são aperfeiçoadas e articuladas, possibilitando uma nova reorganização das competências. Destarte, é mais do que evidente a imagem do neoliberalismo porquanto a economia está à frente da sociedade e estabelece a primazia dos desafios econômicos de produção em relação a qualidade de vida em sociedade. Não obstante, o impulso devorador das novas tecnologias se nutre também de sua imbricação econômica: seu significado econômico ultrapassa, de longe, seu significado social. Nossa função maior continua a ser o consumo. 
Portanto, é correto afirmarmos que as habilidades do século XXI não nos tornam, necessariamente, "mais hábeis" para nós mesmos, mas mais "bem encaixados" no ritmo da produtividade neoliberal (DEMO, 2008).

De acordo com esse contexto curricular mais amplo a Geografia escolar tem grande importância para o desenvolvimento de habilidades e competências que os sujeitos cognoscentes precisam assimilar não apenas para se inserirem no mercado de trabalho, mas também para o exercício da cidadania. Destarte, conforme prescreve as Orientações Curriculares para o Ensino Médio (2006), a Geografia escolar está fundamentada nos conceitos de natureza, paisagem, espaço, território, região, rede, lugar e ambiente. Esses conceitos-chave são complementados por outras dimensões analíticas que contemplam tempo, cultura, sociedade, poder e relações econômicas e sociais. O próprio documento reafirma que

\begin{abstract}
A Geografia não é uma disciplina descritiva e empírica, em que os dados sobre a natureza, a economia e a população são apresentados a partir de uma sequência linear, como se fossem produtos de uma ordem natural. Com as novas tecnologias de informação, com os avanços nas pesquisas cientificas e com as transformações no território, o ensino de Geografia torna-se fundamental para a percepção do mundo atual. (p. 43)
\end{abstract}

Por conseguinte, as Orientações Curriculares também destacam importantes conceitos e temas ligados à globalização, à técnica e à organização dos fluxos e das redes, questões indispensáveis para que os estudantes entendam o papel das tecnologias da informação e da comunicação para o rearranjo das formas de organização socioespacial do trabalho e do consumo, além de indicar novas formas de apropriação dos sistemas naturais. De forma complementar, todos os documentos e leis são uníssonos na defesa de um ensino que desenvolva a capacidade crítica de interpretação da realidade, a autonomia intelectual, o desenvolvimento ético de uma forma pensar e agir no mundo, entre outras premissas que orientam o ensino médio. Todavia, prevalece uma concepção de formação de cidadãos que se enxergam como indivíduos, mas não se entendem como classe, ou seja, a visão de sociedade constante nessa reorganização curricular é formada pela reunião de indivíduos e não pela união contraditória de classes sociais em luta (OLIVEIRA, 1999 apud SILVA, 2016). 
Esta constatação reforça uma marcante contradição presente naqueles documentos relacionada ao amplo espaço conferido à "Geografia crítica", com a citação de autores e referências explícitas ao posicionamento teórico crítico, que, todavia, não se concretiza no currículo. O texto dos PCNs é bastante claro ao enfatizar a necessidade de abandonar a visão mnemônica, a repetição enfadonha etc.; destacando o fato da Geografia ter se tornado uma ciência autônoma no final do século XIX, e chegar ao final do século XX com interesse renovado, processo que ocorreu no Brasil a partir da década de 1970. A contradição nos parece evidente quando as Orientações Curriculares asseveram que a importância da Geografia no ensino médio

Está relacionada com as múltiplas possibilidades de ampliação dos conceitos da ciência geográfica, além de orientar a formação de um cidadão no sentido de aprender a conhecer, aprender a fazer, aprender a conviver e aprender a ser, reconhecendo as contradições e os conflitos existentes no mundo. (2006. p. 44)

A disciplina está, portanto, inexoravelmente comprometida com as propostas neoliberais que conduziram todo o processo de reordenação curricular, cabendo refletirmos a proposição ontológica que esta conduta viceja. Se recuperarmos todo o trajeto do currículo escolar, inclusive o de Geografia a partir de meados do século XIX, resta óbvio que sempre estivemos diante de um projeto escolar burguês. Se nos séculos passados a educação consistia em artigo de luxo de determinadas classes privilegiadas que precisavam se preparar para o exercício dirigente, a exclusão do sistema escolar já era por si só indicativo do destino a ser percorrido pelos excluídos. Posteriormente, já no período republicano, a ampliação da escolarização pontificou, em diferentes momentos e de diferentes formas, quem deveria seguir o caminho da intelectualidade e quem deveria cumprir jornadas laborais exaustivas e fisicamente desgastantes. Vemos que o pensamento burguês, consolidado ao longo de todo o tempo no Estado brasileiro, não deixou margem para que uma outra educação fosse pensada, ainda que possamos registrar movimentos subversivos que se desenvolveram nas fissuras do sistema, mas que, via de regra, também foram combatidos.

Destarte, é preciso ter clareza que nesse período do final do século $\mathrm{XX}$, a reordenação curricular cumpriu o mesmo papel das reformas anteriores: garantir o pleno funcionamento de um Estado burguês, com sujeitos cognoscentes respeitando 
a ideia de cidadania burguesa e, talvez principalmente, aperfeiçoando seus corpos e mentes para o trabalho, categoria que precisa ser centralizada pela ciência geográfica por consistir, segundo Marx, na mediação entre o homem e natureza. Por conseguinte, após toda a discussão empreendida, acreditamos que todo esse debate ontológico encontra seu fundamento quando a categoria adquire destaque. Vejamos essa proposição.

Marx tem como premissa teórica o trabalho enquanto atividade de autoconstrução do homem pois o trabalho ao transformar a natureza consiste, ao mesmo tempo, num processo fundante do devir humano, bem como torna a natureza em mundo humano, histórico-social. Neste sentido, o trabalho pode ser encarado em sua dimensão ontológica positiva, como possibilidade do desenvolvimento humano, permitindo, segundo Lukács (2013), a passagem do simples ser biológico para o ser social. Portanto, tornar-se social pela via do trabalho significa compreender que a relação entre o sujeito (homem) e a natureza (espaço) se dá de forma recíproca no processo de auto constituição do homem. Portanto, o processo de humanização do homem é essencialmente espacial. Para avançarmos por essa via investigativa precisamos esmiuçar um pouco mais a categoria trabalho.

As características do trabalho são reflexos do modo de produção capitalista, que está assentado no seio das relações capitalistas de produção como uma ação não definida por quem o executa. Marx (1983) já anunciara que o "trabalhador trabalha sob o controle do capitalista a quem pertence seu trabalho" e, da mesma forma, "o produto é propriedade do capitalista, e não do produtor direto, do trabalhador". Nesse contexto, é correto afirmar que o "processo de trabalho é um processo entre coisas que o capitalista comprou, entre coisas que lhe pertencem” (p. 154). Assim, processo e produto do trabalho assalariado pertencem ao capitalista que paga ao trabalhador por sua força de trabalho e o insere no interior do processo produtivo.

Por conseguinte, é fundamental destacar a atuação do currículo escolar na formação dessa força de trabalho, consistindo num meio para a valorização do valor. Uma vez subordinada ao capital, a força de trabalho só se realiza ao ser vendida e comprada no mercado, sendo incluída como meio para a valorização do valor, finalidade última do modo de produção capitalista. Sabe-se, ademais, que a força de trabalho não é uma mercadoria qualquer, mas uma mercadoria que tem 
como valor de uso a capacidade de produzir mais valor. Portanto, é nessa mercadoria única que o capitalismo guarda um importante agente de valorização, a força de trabalho que tem como característica marcante o poder de gerar mais valor durante a produção, fundamento basilar do modo de acumulação capitalista.

O mergulho nas proposições marxistas torna-se importante instrumento elucidativo da realidade que queremos apresentar e dos objetivos que pretendemos alcançar. Em torno dessa discussão sobre mercadoria, emerge o antagonismo entre o valor de uso e o valor de troca. A oposição surge justamente a partir de dois conteúdos: o valor de uso, relacionado ao aspecto material, detentor da capacidade de, enquanto mercadoria, satisfazer as necessidades humanas; e o outro, valor de troca, ou somente valor, de caráter social, condensando uma quantidade de trabalho abstrato objetiva ao longo do seu processo de produção que permite uma correlação e troca entre mercadorias. Marx, acerca disso, escreve que

\begin{abstract}
As mercadorias vêm ao mundo sob a forma de valores de uso ou de corpos de mercadorias, como ferro, linho, trigo etc. Essa é sua forma natural com que estamos habituados. Elas são só mercadorias, entretanto, devido à sua duplicidade, objetos de uso e simultaneamente portadores de valor. Elas aparecem, por isso, como mercadoria ou possuem a forma de mercadoria apenas na medida em que possuem forma dupla, a forma natural e forma de valor. (1983, p. 53).
\end{abstract}

Os referidos conteúdos são originados de duplo aspecto do trabalho produtor de mercadorias, ou seja, trabalho concreto e trabalho abstrato. O primeiro diz respeito os trabalhos particulares dos trabalhadores, como alfaiates, operários, professores etc.; já o segundo, também chamado de trabalho socialmente necessário, consiste numa substância social gerada pela relação objetiva de diferentes trabalhos concretos, possuindo como determinação qualitativa seu caráter geral, isto é, o emprego de força e inteligência humanas. Mais uma vez, Marx nos ensina que

O corpo da mercadoria que serve de equivalente figura sempre como corporificação do trabalho humano abstrato e é sempre o produto de determinado trabalho concreto, útil. Esse trabalho concreto torna-se, portanto, expressão do trabalho humano abstrato (1993. p. 61).

Em outro momento, o filósofo alemão é ainda mais elucidativo ao explicar que 
O caráter místico da mercadoria não provém, portanto, de seu valor de uso. Ele não provém, tampouco, do conteúdo das determinações de valor. Pois, primeiro, por mais que se diferenciem os trabalhos úteis ou atividades produtivas, é uma verdade fisiológica que eles são funções do organismo humano e que cada uma dessas funções, qualquer que seja seu conteúdo ou forma, é essencialmente dispêndio de cérebro, nervos, músculos e sentidos etc. Segundo, quanto ao que serve de base à determinação da grandeza de valor, a duração daquele dispêndio ou a quantidade de trabalho, a quantidade é distinguível até pelos sentidos da qualidade do trabalho. (1983. p. 70)

$\mathrm{Na}$ atividade laborativa, o trabalho morto, materializado nas máquinas, ferramentas e utensílios, dominam o trabalho vivo, o que significa que não é o trabalhador que os utiliza, mas os meios de produção que se utilizam dos trabalhadores. Nesse contexto, Marx assevera que os meios de produção não servem para a subsistência imediata dos trabalhadores, mas, na realidade, o trabalhador os serve pela produção de mais-valia ao sugar o trabalho excedente. É assim que o trabalhador é reduzido a um fator do processo de produção, o chamado capital variável. Catini (2013), em um interessante trabalho de doutoramento, auxilia nossa argumentação ao constatar que esta redução das propriedades particulares de cada trabalho concreto, confere ao trabalho um caráter geral, abstrato de mercadoria, tornando possível sua aquisição e produção no mercado. Exatamente essa abstração das atividades que produzem e reproduzem a vida social pode ser considerada uma abstração real, manifestada na realidade, tornando o trabalho abstrato a base de funcionamento do sistema capitalista.

De acordo com estas premissas é possível considerar o trabalho como um criador dos valores de uso, uma necessidade fundamental à existência humana pela intercambialidade entre o homem e a natureza. Não obstante, no modo de produção capitalista, o trabalho está estruturado sob condições alienantes (estranhadas) porquanto os produtos da atividade humana tornam-se autônomos em relação aos seus produtores. Esse fato ocorre porque tanto o trabalhador quanto o produto de seu trabalho são transformados em mercadoria e apenas são socialmente válidos enquanto tal. Portanto, o trabalho, ainda que consista numa atividade basilar da existência humana, se manifesta, no capitalismo, prioritariamente como trabalho abstrato, estranhado, criador de valor de troca porque só importa ao capitalista o seu valor de troca e lucro possível. O resultado dessa situação é que o trabalho sob a forma social de mercadoria adquire, como já assinalado, caráter misterioso em 
virtude de as relações produtivas entre os homens serem reificadas ao se manifestarem sob a forma social de objetos.

Deste modo, o trabalhador, proprietário de sua força de trabalho, somente alcança existência para o capitalista enquanto mercadoria. Essa constatação é fundamental em nossa proposta ontológica porque, com base nas proposições marxianas, o ser social somente o é através do trabalho, ou seja, de sua relação com o espaço, no entanto o currículo escolar de Geografia promove uma relação estranhada com o espaço porque não há interesse no homem, apenas na mercadoria força de trabalho. Esta consideração é derivada de um posicionamento marxista, corrente filosófica que encontrou terreno fértil na Geografia, permeou docentes e documentos oficiais de educação, mas que, em nosso entender, não se materializou em conteúdos. O currículo escolar de Geografia, pela perspectiva neoliberal, não nos parece outra coisa senão um mecanismo de reprodutor de força de trabalho (agora flexível) para a execução das demandas produtivas.

Por fim, já nos encaminhando para o final deste capítulo, observamos como os próprios documentos orientadores circundam a temática do trabalho, mas não a abordam adequadamente, promovendo uma espécie de fetichização do trabalho no currículo escolar. Selecionamos alguns dos trechos dos documentos oficiais que corroboram nossa proposição, a começar pelas diretrizes curriculares nacionais do ensino médio, que em seu art. 10 (DCN, 1998) quando tratam dos objetivos das Ciências Humanas afirmam:

III - Ciências Humanas e suas Tecnologias, objetivando a constituição de competências e habilidades que permitam ao educando:

[...] b) Compreender a sociedade, sua gênese e transformação e os múltiplos fatores que nelas intervêm, como produtos da ação humana; a si mesmo como agente social; e os processos sociais como orientadores da dinâmica dos diferentes grupos de indivíduos.

[...] c) Compreender o desenvolvimento da sociedade como processo de ocupação de espaços físicos e as relações da vida humana com a paisagem, em seus desdobramentos políticosociais, culturais, econômicos e humanos.

[... f) Entender os princípios das tecnologias associadas ao conhecimento do indivíduo, da sociedade e da cultura, entre as quais as de planejamento, organização, gestão, trabalho de equipe, e associá-las aos problemas que se propõem resolver. 
Como podemos perceber, as diretrizes curriculares sugerem o entendimento da sociedade e das tecnologias, em diferentes manifestações, como objetivos das Ciências Humanas, todavia não expressam a importância de apreender estas transformações numa sociedade de classes, tampouco estipulam o trabalho como categoria de medicação fundamental para a compreensão da organização e desenvolvimento da sociedade. Em nenhum momento, o documento cita a palavra "contradição" ou estabelece como objetivo algo relacionado às desigualdades. Destarte, há uma mensagem implícita indicando que a vida se dá numa sociedade regulada por mecanismos de controle (social, político e econômicos) consolidados, os quais devemos conhecer e aceitar convenientemente seu funcionamento. Entendemos ser um legítimo convite ao imobilismo.

Em outro documento, os PCNs, encontramos posicionamentos mais próximos aos apregoados pela Geografia crítica, especialmente quando asseguram que o ensino médio é o momento de ampliação das possibilidades de um conhecimento estruturado e mediado pela escola que conduza à autonomia necessária para o cidadão do próximo milênio. Seguindo os três princípios filosóficos da concepção curricular - princípios estéticos, políticos e éticos -, a Geografia contribui para esta formação, proporcionando ao aluno, entre outras competências:

Reconhecer as contradições e os conflitos econômicos, sociais e culturais, o que permite comparar e avaliar qualidade de vida, hábitos, formas de utilização e/ou exploração de recursos e pessoas, em busca do respeito às diferenças e de uma organização social mais equânime; (p. 31)

Mais a frente o mesmo documento assinala que

Um importante conjunto de conceitos refere-se à globalização, técnica e redes. É necessário ter clareza que a globalização é um fenômeno decorrente da implementação de novas tecnologias de comunicação e informação, isto é, de novas redes técnicas, que permitem a circulação de idéias, mensagens, pessoas e mercadorias num ritmo acelerado, e que acabaram por criar a interconexão entre os lugares em tempo simultâneo. Neste processo, tiveram papel destacado a instalação de redes técnicas, incluindo-se a indústria cultural, a ação de empresas multinacionais e a circulação do capital, que intensificaram as relações sociais em escala mundial, interligando localidades distantes, de tal maneira que acontecimentos locais são 
modelados por eventos ocorridos a milhares de quilômetros de distância.

No que se refere à técnica, devemos ressaltar ainda a importância da compreensão do papel das inovações tecnológicas na esfera da produção de bens e serviços, engendrando novas formas de organização social no trabalho e no consumo, criando novos arranjos espaciais. Outra face da revolução tecnológica são as novas formas de apropriação da natureza, tais como as expressas na biotecnologia, em que a detenção do conhecimento e do domínio técnico são também um instrumento de poder que afeta os grupos sociais e exige modificações na organização espacial existente. (p. 33/34)

Neste sentido está bastante nítida a defesa de uma análise crítica das contradições marcantes da sociedade com vistas a uma "organização social mais equânime”, porém este objetivo nos parece comprometido, já que a compreensão da globalização e de todo o desenvolvimento técnico concernente a terceira revolução industrial passa ao largo dos impactos promovidos pelo toyotismo e pela intensificação do neoliberalismo na estruturação produtiva, revelando que a categoria trabalho permanece ausente das discussões geográficas escolares, ou seja, não se discute o trabalho como produtor de valores de troca nem como pilar da relação estranhada do homem com o espaço.

No documento de orientações curriculares são apresentados eixos temáticos, responsáveis por estruturar e organizar as principais questões a serem debatidas pela Geografia escolar. Os sete eixos apresentados são: "formação territorial brasileira", "Estrutura e dinâmica de diferentes espaços urbanos e o modo de vida na cidade, o desenvolvimento da Geografia Urbana mundial”, "O futuro dos espaços agrários, a globalização a modernização da agricultura no período técnico-científico informacional e a manutenção das estruturas agrárias tradicionais como forma de resistência", "Organização e distribuição mundial da população, os grandes movimentos migratórios atuais e os movimentos socioculturais e étnicos, as novas identidades territoriais", "As diferentes fronteiras e a organização da geografia política do mundo atual, estado e organização do território", "As questões ambientais, sociais e econômicas resultantes dos processos de apropriação dos recursos naturais em diferentes escalas, grandes quadros ambientais do mundo e sua conotação geopolítica" e, finalmente, a "Produção e organização do espaço geográfico e mudanças nas relações de trabalho, inovações técnicas e tecnológicas 
e as novas geografias, a dinâmica econômica mundial e as redes de comunicação e informações".

O último item nos é mais interessante, não apenas por ser o único que menciona o "espaço geográfico", mas principalmente por priorizar a sua produção e organização. Este eixo transparece diversos conteúdos importantes, mas, mais uma vez, o trabalho é apenas apresentado em sua dimensão fenomênica, delineando as mudanças nos modelos produtivos e suas respectivas alterações no espaço geográfico. Destarte, o currículo escolar está pautado pela preparação imediata ao trabalho laboral, ao desenvolvimento de habilidades a partir de conteúdos instrumentais para a formação de uma força de trabalho.

Portanto, as transformações provocadas pelo neoliberalismo no trabalho e na vida social também reverberam nos currículos escolares de modo a procurar garantir o pleno funcionamento do modo de produção capitalista a despeito de seus efeitos devastadores sobre amplos segmentos da população. Estes sujeitos sofreram as graves consequências sociais provocadas pela combinação de mudanças tecnológicas e de deslocalização produtiva, como desemprego prolongado, deterioração da infraestrutura social e perda das solidariedades comunais (HARVEY, 2016). Por seu turno, os currículos escolares se limitaram a serem instrumentos formadores de mão de obra para o mercado, que é considerado a base real a partir de onde se fundam todas as relações sociais, políticas e jurídicas. Por conseguinte, o relacionamento humano se dá basicamente entre sujeitos reconhecidos como proprietários de mercadorias, fato derivado do desconhecimento acerca da categoria trabalho como mediação da relação sujeitoespaço e que em tempos neoliberais agudizam o estranhamento das relações humanas. 


\section{Considerações finais}

O encerramento de uma pesquisa assinala não uma conclusão, mas apenas uma interrupção. O objeto pesquisado continua em transformação, o que significa que os objetivos previamente estabelecidos já estão ultrapassados e é a própria pesquisa que demonstra o seu esgotamento perante a dinâmica ininterrupta da totalidade. Encerrar, na realidade, nos parece mais correto desde uma perspectiva pessoal ao sugerir a finalização de um ciclo iniciado anos atrás e que precisa chegar a termo com a produção de um documento que formalize este momento. Não temos a ilusão de que este documento represente tudo o que foi discutido ou aprendido ao longo destes anos, fato que demonstra mais uma vez sua limitação quando relacionada com o real.

É inevitável chegar até aqui e não recuperar memórias que construíram este estudo de forma tão marcante. Esta pesquisa nasceu de uma experiência pessoal e inevitavelmente seu encerramento também precisa encontrar correspondência em momentos vividos e que são, de fato, pedras que pavimentaram toda a trajetória desta jornada. Nossa opção foi por estruturar o momento final deste estudo articulando as principais questões debatidas sem uma preocupação muito rígida com a sequência dos capítulos e, por vezes, aprofundando posicionamentos com base numa correlação temática.

Nossa pesquisa procurou demonstrar como o currículo escolar de Geografia colabora para que se desenvolva uma relação estranhada entre os sujeitos cognoscentes e o espaço, tese que demandava o posicionamento do escopo de análise sobre esta relação, ou seja, nosso estudo não poderia se prender nem sobre a questão estritamente escolar nem em temas exclusivamente espaciais, mas em uma das manifestações de interpretação desta inexorável relação entre sociedade e espaço, ou seja, o currículo escolar oficial de Geografia. Quando abordamos os chamados "sujeitos cognoscentes" estamos, na verdade, tratando da sociedade em seu período de "gestação" para o "exercício da cidadania" e para o "mundo do trabalho".

À vista disso, nos propusemos, em primeiro lugar, a esmiuçar nosso entendimento acerca da ontologia, considerando sua longa tradição filosófica e as transformações pelas quais passou. Portanto, o início de jornada foi marcado pela tentativa de desenvolvimento de uma discussão suficientemente capaz de 
fundamentar nosso estudo, objetivo que exigiu um grande esforço investigativo para encontrarmos balizas teoricamente sólidas. Inegavelmente procuramos organizar nossa investigação partindo de uma realidade concreta, aquele fato ocorrido numa sala dos professores com o embate em tom de desafio entre a maturidade profissional e a juventude aprendiz. Aquele dia foi revisitado diversas vezes, de diferentes formas e por diferentes ângulos, sempre revelando um aspecto que considero hoje de importância radical: somos herdeiros de tradições científicas “desespacializantes". Aqui não me refiro apenas à Geografia, mas aos movimentos científicos que tivemos oportunidade de apresentar, especialmente ao longo do primeiro capítulo.

Como podemos perceber no desenrolar daquele capítulo, houve uma espécie do pacto na transição do feudalismo para o capitalismo que definiu o quinhão de abordagem da religião e da ciência: À primeira coube o mundo metafísico e à segunda o mundo físico. Destarte, o conhecimento dos entes corpóreos restou sobre incumbência da ciência e a filosofia focou o estudo do homem. É bem verdade que essa cisão entre corpo e homem já estava em curso desde a Antiguidade, todavia a filosofia cartesiana confere ares de modernidade a essa separação por intermédio de sua concepção de espaço (MOREIRA, 2015).

A ciência, a partir das formulações metodológicas cartesianas, apartou o sujeito do espaço, colocando-o em correspondência direta com o indivíduo, com a pessoa, o eu. A cisão entre res cogitans e res extensa impele que tudo no mundo é espacial, exceto o "eu", proclamando uma ontologia arraigada na dicotomia entre espaço e homem. Separar o "eu" do espaço, conceber uma ciência objetiva e universal, afastar o sujeito pensante do objeto de estudo são algumas das transformações que ocorreram na ciência moderna e que são, de forma até bastante frequente, retóricas discursivas presentes na realidade escolar contemporânea.

É justamente esse cenário que contextualizo naquela ocasião vivenciada na sala dos professores. Uma quase comovente defesa de um conhecimento distanciado do espaço, conhecimento refém de informações vazias de significado e prenhe de pobres representações de uma ciência que se quis universal e objetiva. Esta ciência desejada adquiriu status de verdade absoluta com as chamadas "leis da natureza", apresentadas pela física e com o declarado objetivo de descrever mudanças pela análise da variação, ao longo do tempo, dos movimentos por uma 
velocidade. As leis de Newton representaram o triunfo do ser sobre o devir e sustentaram, de forma inconteste, a separação do homem do espaço, cindindo a realidade em materialidades opostas, com o pretenso poder de prever fenômenos e enxergar com a regularidade matemática as aparências fenomênicas.

É interessante relacionarmos esta situação com o desenvolvimento do próprio modo de produção capitalista, conforme apresentamos ao longo de diferentes momentos de nosso texto. A reprodução da força de trabalho não exige apenas a reprodução de sua qualificação, mas também a reprodução de sua submissão à ideologia dominante a partir da combinação perversa dos mecanismos de controle social sob tutela do Estado. Aparatos ideológicos ou repressivos diversos estruturam uma ampla e profunda rede de difusão ideológica que garante a cada classe social o conhecimento de seu papel na sociedade de classes.

Podemos recorrer aos escritos de Marx (1996) para complementar esta discussão quando o filósofo escreve que

\begin{abstract}
A burguesia nascente precisa e emprega a força do Estado para "regular" o salário, isto é, para comprimi-lo dentro dos limites convenientes à extração de mais-valia, para prolongar a jornada de trabalho e manter o próprio trabalhador num grau normal de dependência. Esse é um momento essencial da assim chamada acumulação primitiva. (p. 355)
\end{abstract}

O trajeto histórico do modo de produção capitalista indicou uma profunda colaboração entre Estado, através da promulgação de leis e do monopólio da violência, e a classe industrial na condução da formação dessa inédita força de trabalho. Essa solidariedade exacerbou os limites da ação jurídica e do uso da violência, chegando às "instituições disciplinares”, com a criação de instituições de caridade, prisões, orfanatos, asilos para o confinamento e docilização de todos aqueles que ainda não tinham se integrado à nova ordem social. Mészáros (2008) afirma que esse cenário só se altera com a própria mudança das condições de produção, que modifica "a necessidade de uma força de trabalho - grandemente ampliada - sob as condições expansionistas da revolução industrial” (p. 39).

O modo de produção capitalista, não obstante, separa a força e o produto do trabalho, enquanto a disciplinarização estabelece no corpo o elo coercitivo entre uma aptidão aumentada e uma dominação acentuada. É justamente em meio a esse contexto político-social que surgiu uma imperiosa necessidade de empreender uma 
"docilização econômica" diária do sujeito através do seu corpo, por meio de um mecanismo técnico-político que unificasse processos empíricos, para controlar ou corrigir as operações e movimentos do corpo, convergindo em prol da submissão e da utilização (FOUCAULT, 2004). Dessarte, a "docilização econômica” passou a vigorar e ser incentivada em diversos espaços disciplinares, instituindo uma "pedagogia econômica" para a formação de força de trabalho através da ação direta do Estado. É curioso pensar que esse raciocínio persiste até hoje, quando boa parte da sociedade civil e representantes do Estado pleiteiam regimes de trabalho em institutos penais ou em escolas com o argumento de estarem formando "cidadãos de bem". Foucault (Idem) é bastante claro nesse aspecto ao demonstrar a exigência da construção do Homo oeconomicus, ou seja, um sujeito economicamente ajustado aos novos tempos. Assim, o pensador francês escreve que

Essa pedagogia [universal do trabalho] tão útil reconstituirá no indivíduo preguiçoso o gosto pelo trabalho, recolocá-lo-á por força num sistema de interesses em que o trabalho será mais vantajoso que a preguiça, formará em torno dele uma pequena sociedade reduzida, simplificada e coercitiva onde aparecerá claramente a máxima: quem quer viver tem que trabalhar. Obrigação do trabalho, mas também retribuição que permite ao detento melhorar seu destino durante e depois da detenção. (Idem. p.100/101)

Mészáros (2008) assegura que as instituições educacionais tiveram de se adaptar com o tempo de acordo com as determinações reprodutivas em mutação do sistema do capital, o que impeliu um abandono das práticas violentas e de extrema brutalidade legalmente impostas como instrumentos de educação. Por conseguinte, é fundamental assinalar que

As determinações gerais do capital afetam profundamente cada âmbito particular com alguma influência na educação, e de forma nenhuma apenas as instituições educacionais formais. Estas estão estritamente integradas na totalidade dos processos sociais. Não podem funcionar adequadamente exceto se estivem em sintonia com as determinações gerais da sociedade como um todo (p. 43).

A estreita vinculação existente entre as instituições escolares e o desenvolvimento do modo de produção capitalista não é novidade e, como tentamos demonstrar, produz transformações inquestionáveis nos sujeitos cognoscentes, ou melhor, na sociedade. Por conseguinte, emerge uma reflexão fundamental que tentamos abordar em nossa pesquisa acerca da estreita vinculação que há entre a 
"inevitabilidade do capital" e a "inevitabilidade de uma outra escola" e, por conseguinte, de outro currículo, ou seja, a perspectiva de eternidade do capital estimula a ideia de que uma outra escola e um outro currículo escolar não é possível, o que, em nosso entender, colabora firmemente para assegurar a manutenção inabalável do modo de produção capitalista. Uma vez consolidada esta perspectiva, o modo de produção dominante se apropria das instituições escolares e as molda e estrutura segundo seus interesses, combinando, destarte, dois movimentos integrados, cuja finalidade é a mesma: o progresso técnico-industrial e a "formação escolar" em prol da composição de uma força de trabalho disponível a garantir a reprodução do capital.

O desenvolvimento técnico abriu espaço para a inserção produtiva de mulheres e crianças, tornando-as vendedoras de uma mercadoria valiosa e o processo de escolarização, por seu turno, oferecia a formação de uma força de trabalho disposta a se colocar como valor de troca, disciplinada a executar as tarefas que se apresentassem em virtude da necessidade de alcançar os meios de sua subsistência. Não é de outra forma que uma das questões mais centrais para a lógica capitalista é assegurar que os trabalhadores adotem como seus os objetivos e necessidades da reprodução do sistema, internalizando os valores, símbolos, projetos e concepções expostos pelos sujeitos dominantes. Mészáros (2008), por exemplo, anunciara que a educação institucionalizada, especialmente nos últimos 150 anos, serviu ao propósito de não só fornecer os conhecimentos e o pessoal necessário ao processo produtivo, como também gerar e difundir um amplo quadro de símbolos e ideias que legitima os valores dominantes, induzindo à crença de uma inevitabilidade de gestão capitalista da sociedade "seja na forma 'internalizada' (isto é, pelos indivíduos devidamente 'educados' e aceitos) ou através de uma dominação estrutural e uma subordinação hierárquica e implacavelmente impostas" (p. 35).

Esta perspectiva é nítida quando analisamos os diferentes períodos da história brasileira e verificamos que desde os jesuítas a educação é conduzida pelos interesses da classe dominante, segundo seus objetivos econômicos, sociais e políticos. Outrossim, as políticas curriculares implementadas estiveram pautadas pelas concepções ideológicas dominantes, funcionando como engrenagens do modo de produção capitalista. Estabilizar a reprodução da sociedade mercantilista 
figurou entre os principais objetivos da Companhia de Jesus e que buscou garantir tal intento com a formação de quadros para a administração do empreendimento colonial, bem como com a ordenação de padres e educação das classes dominantes, tudo isso orientado pedagogicamente pelo Ratio Studiorum.

Mesmo as reformas pombalinas não alteraram esta orientação, ainda que tenham trazido a educação para o colo do Estado. Destarte, até meados do século XIX, podemos inferir que o currículo cumpria seu objetivo ao impor a concepção de mundo do colonizador e formando o administrador da sociedade segundo os parâmetros (político-econômicos) lusitanos e excluindo da maioria da população o acesso às instituições escolares. A independência política mantém a dependência econômica e as atividades produtivas predominantes permanecem atreladas ao latifúndio agroexportador e à mão de obra escrava. Particularmente, o ensino secundário estava voltado ao ensino superior porquanto o currículo foi todo o pensado em função das necessidades dos exames parcelados.

Naquele período entra em cena um agente importante para atender com grande eficácia a formação da elite nos moldes europeus, com caráter enciclopédico e informativo: o Colégio Pedro II, criado em 1837. Zotti (2004) nos fala da incorporação de novos conhecimentos científicos nas matrizes curriculares, mas "não como uma nova forma de compreender o mundo, mas com o objetivo de enriquecer a erudição da intelectualidade” (p. 216). É neste interim que nossa disciplina adentra os currículos escolares com o claro objetivo de ampliar o conhecimento das classes dominantes acerca dos lugares, informações que somente pessoas ilustradas conseguiriam obter, tendo em vista a posição social que ocupavam. Uma sociedade excludente, como a brasileira, não poderia impedir que a educação também fosse reflexo e reforço desse processo.

A Proclamação da República também não alterou a defesa dos antigos interesses da aristocracia latifundiária cafeeira, significando, em linhas gerais, um reordenamento do Estado para atender aos interesses políticos e econômicos dos grupos hegemônicos. Neste sentido, o governo federal manteve a política educacional imperial ao assegurar as condições de existência e funcionamento do ensino secundário e superior, aparatos de formação da elite (ZOTTI, 2004). A despeito das diversas reformas ocorridas naquele período, o papel social e político da educação não foi alterado, e de acordo com nossas pesquisas a manutenção do 
controle sobre o aparato educativo sempre foi considerado um importante elemento para as classes dominantes.

Momento importante da história nacional, a "Revolução de 1930" marcou um rearranjo dos poderes dominantes com o declínio dos aristocratas cafeicultores e o consequente início da substituição do modelo econômico capitalista agroexportador por outro igualmente dependente, mas de viés urbano-industrial. Não obstante, ocorreu uma complexificação da sociedade e o recrudescimento do desejo de frequentar as salas de aula, provocando, pela primeira vez, o desenvolvimento de um projeto nacional para a educação. Todavia, é importante frisar que esse movimento em prol da educação continha o objetivo de atender ao desenvolvimento econômico-industrial, em conformidade com os interesses da minoria dominante.

A ideia de um "projeto nacional" para a educação brasileira guarda um importante aspecto da lógica própria do capitalismo, que, como sabemos, produz relações reificadas entre as pessoas ao estabelecer um momento de igualdade formal entre desiguais. Nesse caso, a desigualdade é promovida pelo próprio documento curricular oficial, ou seja, reside no fato de que os sujeitos cognoscentes conhecem um currículo único, um documento que em teoria unifica os conteúdos e a organização do sistema educacional, mas cada um o vivencia como uma experiência particular, e que se difere de outras na medida em que há diversidade nas formas de apropriação e internalização das vivencias escolares, segundo, entre outros fatores, a classe social. Partindo desta premissa, e concordando com Baudelot e Establet (1990), compreendemos que esta capacidade "universal" é o principal aspecto das instituições escolares e, acrescentamos, por conseguinte, do currículo escolar enquanto documento oficial de âmbito nacional porquanto ele materializa aquela capacidade de ação imaginada pelos liberais, a saber unificar o que a política divide ou, ao menos, consegue se estabelecer à margem e acima das divisões políticas. É através desta perspectiva que se procura estruturar um "grupo social homogêneo" ou o mais homogêneo possível, como se tenta efetivar com a classe trabalhadora. Gramsci defendeu a necessidade de desenvolvimento de uma concepção de mundo própria, sistemática e coerente com uma atividade que vise transformar a realidade, ou seja, uma filosofia da práxis. 
Neste contexto, não é exagero pensarmos que a ampliação da educação no país provocada especialmente a partir de 1930, período que evidencia de forma explícita o vínculo íntimo entre desenvolvimento econômico e o sistema escolar, promoveu uma maneira dominante de educar e unificou uma experiência de sociabilidade, como uma vivência genérica, na medida em que expandiu seu acesso. Destarte, é possível perceber que a ampliação da instituição escolar, organizado pelo Governo Federal, procurou estimular o ingresso do país num novo ciclo econômico, ou seja, o fortalecimento dos liames políticos e econômicos entre o projeto de país e o sistema educacional ganharam novo sentido e adquiriram movimento através do currículo comum. Não temos a intenção de amplificar o poder ideológico da escola, como se esta instituição fosse capaz de sedimentar concretamente seus objetivos em todo o corpo social, mas, em nosso entender, é inegável a função mediadora/difusora destas instituições entre o modo de produção, e suas estratégias reprodutivas, e a sociedade. Neste sentido, é correto afirmarmos que a consolidação da ordem econômico-social foi o resultado possível do recrudescimento do modo de produção capitalista assentado sobre estruturas tradicionais, gestadas sob formas primitivas de dominação do capital, e que proporcionaram uma consciência nacional frágil e dependente, típica de países que trafegaram do colonialismo ao capitalismo. Portanto, a ideologia em torno da educação foi produzida pela consciência burguesa e liberal dominante e adequou o sistema escolar às funções exigidas pela sociedade que se produzia em meio a uma ordem capitalista dependente e excludente.

Não é de outra forma que procuramos demonstrar que a coleção de informações apresentada pela escola funciona para as classes dominantes como um elemento de coesão e manutenção, todavia para as classes subalternas, que, em geral, desconhecem esses sistemas, ela é sempre uma força externa, um elemento de subordinação a uma hegemonia exterior. É justamente como uma crítica desses sistemas dominantes que defendemos a adoção de uma filosofia da práxis, que, como vaticina Gramsci (2015) "só pode ser concebida em forma polêmica, de luta perpétua" (p. 93). Todavia, é fundamental não perder de vista que "o ponto de partida deve ser sempre o senso comum, que é espontaneamente a filosofia das multidões, as quais se trata de tornar ideologicamente homogêneas" (Ibidem). 
A reflexão por estas questões revelou os diferentes caminhos que expressam como a política educacional reflete a dominação burguesa, seja pelo rígido controle ao acesso ou pelas diversas reformas implementadas, sempre a serviço dos interesses econômicos dos grupos hegemônicos. Neste contexto, o alinhamento do sistema educacional aos objetivos do Estado capitalista autoritário significou a subordinação da educação à produção capitalista através da promulgação da lei $5692 / 71$. A partir de então a obrigatoriedade do ensino de $2^{\circ}$ grau profissionalizante ou a iniciação para o trabalho já no $1^{\circ}$ grau, e ainda a implantação dos Estudos Sociais indicavam a lógica dominante e mascaravam através de uma aparência de igualdade de oportunidades a profunda concentração de renda do país. Esta constatação adquire ainda mais sentido quando observamos que a classe dominante continuou com sua formação necessária para o acesso ao ensino superior, enquanto os filhos da classe trabalhadora tinham seu acesso limitado por sua condição financeira e pela própria escola profissionalizante, que o deixava em desvantagem ao competir por uma vaga nas universidades.

Não resta dúvida de que se procurou atender às necessidades do capital com base numa formação técnica, alienante e desvinculada da crítica social, proposta que ganha materialidade com as orientações curriculares, marcadas pelo tecnicismo que determinava a organização do espaço escolar, o controle ideológico através de disciplinas específicas ou pela racionalização de recursos (ZOTTI, 2004). Esta relação entre educação e formação para o trabalho não é bem uma novidade, mas cabe ressaltar que no caso brasileiro no período ditatorial civil-militar isso se manifesta como um grande projeto discursivo para viabilizar o "Brasil-potência", fato que chama a atenção pois conjuga o desejo de estimular simultaneamente um patriotismo e uma adesão inquestionável aos ditames do capital internacional.

Esta orientação não sofreu alterações na Nova República, que, em termos de políticas educacionais, deu continuidade aos programas dos militares, no entanto os revestiu com um discurso crítico e democrática, repercutindo sobre os currículos escolares. Um novo cenário produtivo se descortinou enquanto a pátria reconstruiu sua organização política, sustentada pela democracia liberal ancorada na Constituição de 1988. Por conseguinte, emergiu o valor universal do toyotismo no momento predominante do complexo de reestruturação produtiva e de nova ofensiva do capital, com a instauração, no plano da produção de mercadorias, de 
"uma 'nova hegemonia' do capital, articulando, de modo original, coerção capitalista e consentimento operário" (ALVES, 2005, p. 413/414).

Portanto, o que se busca hoje, inspirados em valores oriundos dos modelos empresariais, em que predominam a lógica automatizada do self-service são sujeitos com habilidades relacionadas à "responsabilidade individual, [a]o autocontrole e [à] competitividade" (SIBILIA, 2015, p. 241). Em síntese, "são corpos lançados no turbilhão de atualização constante, intimados a maximizar sua flexibilidade e sua capacidade de reciclagem, em permanente competição com os outros" (Ibidem). O modelo de acumulação flexível, nos termos preconizados pelo toyotismo

Tende a promover um agudo investimento na captura da subjetividade, aprofundando os nexos fetichistas e 'estranhados' do capital. Na verdade, [o toyotismo] é um elo significativo desta aguda manipulação social do capitalismo em sua fase de crise estrutural. Atinge o modo de trabalho que se expande para o tempo da vida" (ALVES, 2005, p. 420).

São cada vez mais evidentes como "as transformações estruturais na dinâmica capitalista a partir de sua crise estrutural alteram as práticas subjetivadoras do capital" (ALVES, 2005, p. 420). O capital, dessa forma, obteve meios políticos efetivos para aprofundar "sua dominação política e econômica na produção", passando a utilizar da maneira mais adequada "as capacidades intelectuais do trabalhador", indicando que ao longo das, pelo menos, últimas quatro décadas o capital "aprofundou a lógica de exploração do trabalho" (AMORIM, 2012, p. 114).

Não obstante, a constituição de novos corpos, isto é, de novos sujeitos, em termos ontológicos, conduzem à identificação de um novo mundo em formação. A mecanicidade de outrora está sendo substituída, mais e mais, pelo recrudescimento da bioinformática, obedecendo

Às necessidades de um determinado projeto de sociedade, que hoje vigora em boa parte do planeta globalizado e se encarrega de gerar certos tipos de saberes e de poderes (embora sempre em disputa com vários outros), desencadeando certos problemas e propondo certas soluções (e não outras apesar das resistências que sempre existem). Um mundo, enfim, que incita a configurar certos tipos de corpos e de subjetividades, e que ao mesmo tempo se ocupa de inibir o surgimento de outras modalidades, limitando o campo do possivel ao canalizar produtivamente suas forças (SIBILIA, 2015, p. 245 grifos nossos). 
Em nosso entender a escola, considerando toda a discussão empreendida, tem estreita vinculação com a inibição do surgimento de outras modalidades de saber ou a limitação do campo do possível às forças produtivas. Particularmente a Geografia escolar ao abordar o espaço da forma como mormente faz, ou seja, enquanto produto apartado dos sujeitos, intermedia a estruturação de um entendimento apriorístico da própria dinâmica espacial, tornada mero objeto de uma análise já pronta, previsível e excludente da ação humana. Tal compreensão ao ser internalizada pelos sujeitos projeta subjetividades alheias ao pensamento comunitário, à convivência cooperativa e à apropriação do espaço, tornando-os insensíveis, em sua essência desumanizada (objetivada no mundo da mercadoria), à questão mais radical do gênero humano: a liberdade.

De posse de todo esse debate acerca da relação estranhada que os sujeitos cognoscentes estabelecem com o espaço, tomando como parâmetro os conhecimentos curriculares oferecidos, é possível avançarmos neste último momento de nosso estudo para refletirmos sobre o ideal burguês de liberdade. Esta temática pairou em diversos momentos de nossa reflexão e emergiu com grande destaque neste momento de articulação entre as transformações ocorridas no funcionamento do modo de produção capitalista em relação com as proposições políticas escolares. Neste sentido, como afirma Lima (2014), o ideal burguês de liberdade está no "núcleo conceitual da concepção moderna e etnocêntrica de sujeito", fazendo referência, inclusive às noções de "autonomia e de emancipação, tão caras ao exercício cívico e às lutas sociais de um modo geral” (p. 258). Contudo, esse ideal de liberdade, mediante às contradições da vida moderna e à ação deliberada da escola, coloca o sujeito numa posição de passividade, tornando-o enclausurado em uma "subordinação consentida/despercebida". Neste sentido, o projeto de "liberdade burguesa" não está assentado

Na superação de necessidades reais dos homens e das mulheres em geral, mas de uma forma objetivista que assume uma imagem universalista enganosa. Trata-se de uma liberdade abstrata que é, paradoxalmente, a negação absoluta de uma noção de liberdade que subentenda a emancipação humana, pois, na realidade empírica, não há sequer uma ação que seja de fato livre. (LIMA, 2014. p. 258/259) 
Alves (2005) chega mesmo a afirmar que o sujeito autônomo é

Uma ficção burguesa. É provavelmente a principal promessa civilizatória frustrada pelo capital. O que significa que estamos diante de um processo histórico-dialético intrinsecamente contraditório: o capitalismo em seu devir histórico, com seu sistema social produtor de mercadorias, constituiu (e, ao mesmo tempo, desconstituiu) o sujeito humano autônomo.

Esta discussão guarda uma importância fundamental para nossa proposta geográfica escolar por trazer em seu âmago o questionamento da mercadoria na concertação de subjetividades ${ }^{86}$, de fato, libertadas. A mercadoria, categoria ineliminável da estrutura orgânica do capital, conduz o gênero humano, ao priorizar prerrogativas individuais, a subscrever suas subjetividades em processos de sociabilidade desiguais, demonstrando sua incompatibilidade com o desenvolvimento da liberdade humana. Neste sentido, conforme Lima (2014, p. 259),

A emergência da propriedade privada instaura uma nova conotação do conceito de liberdade, que ficaria reservada a pequenos segmentos da sociedade, isto é, a um sujeito de tipo específico que se apropria do excedente produzido, enquanto priva a maior parte de qualquer gozo de liberdade.

O capital, através da mercadoria, torna factível a alienação de todo o corpo social, de modo que "o próprio homem, na qualidade de provedor da força de trabalho, torna-se também alienável (o caráter material da alienação), isto é, propenso a alienar (vender ou trocar) sua força criativa” (LIMA, 2014. p. 261) e, ele mesmo - o capital -, ao mesmo tempo em que criou as bases materiais para o pleno desenvolvimento da individuação social, "limitou e obliterou esse mesmo desenvolvimento humano-genérico" (ALVES, 2005. p. 420). Nesse interim, a Geografia escolar ao promover a abordagem do espaço da maneira que até aqui tanto criticamos tem sua participação inegavelmente relevante no desestímulo ao desenvolvimento do ser genérico por não realizar nenhuma contraposição à mercadoria nem à propriedade privada, denotando-o, ao que tudo indica, de uma "sacralidade divina" que transforma o espaço em uma forma-mercadoria por

\footnotetext{
${ }^{86}$ Aqui é importante retomar o alerta feito por Alves (2005) de considerar a subjetividade numa perspectiva dialético-materialista, em que "subjetividade e objetividade são determinações reflexivas", impedindo que ocorra uma hipostasiação da subjetividade "desvinculando-a das condições objetivas de produção da vida social” (p. 419/420).
} 
excelência. Portanto esta complexa discussão em torno da constituição do sujeito e das subjetividades tem estreita vinculação com a abordagem geográfica escolar do espaço por trazer à tona o questionamento da vida humana no atual momento de expansão das relações capitalistas de produção no espaço, ou melhor, por “desnaturalizar" um fato tido como inquestionável em nossa sociedade: a inevitável presença da mercadoria como instrumento mediador/limitador de apropriação da vida humana, tanto em termos espaciais quanto em relação à construção da individualidade.

Ao investigarmos os documentos oficiais nacionais que reorganizaram a educação do país, a partir da LDB 9394/96, nos restou claro que o projeto educacional estava dedicado ao atendimento das demandas do capital nacional e internacional, estimulando uma conformidade ideológica combinada com a produção de conhecimentos adequada à divisão internacional do trabalho. Todavia, toda essa conjuntura não é capaz de suprimir os conflitos subjacentes aos interesses de classe que forjam um sentido de identidade e de solidariedade entre os grupos humanos (HARVEY, 2016). A predileção do capital por uma forma de individualismo exacerbado atinge tanto o capitalista quanto o trabalhador e é na constituição desta "amálgama social" que o projeto de educação neoliberal brasileiro procura produzir, através da promoção de uma lucratividade aumentada pela produtividade crescente, uma mão de obra cada vez mais qualificada e flexível.

Não podemos nos furtar de apontar outra constatação fundamental, que evidencia a contradição presente no modo de produção capitalista: é também no interior das políticas curriculares oficiais que estão as pistas para a sua própria subversão, ou seja, é no documento oficial de orientação escolar que podemos enxergar as fissuras para o desenvolvimento de uma possível outra política curricular. Ao mesmo tempo em que o currículo direciona os esforços políticos e econômicos do Estado também abre flancos para a sua transgressão, tornando-se, invariavelmente, terreno fértil para a dissidência, para a subversão. É justamente a existência destas brechas que nos permitem entrever a contradição em favor da formação de indivíduos não conformistas, questionadores, rebeldes, capazes de criticar e de desafiar os valores dominantes e as identidades celebradas no mundo da família e na sociedade mais ampla, estimulando uma consciência de lutas, 
buscas, relações, diálogos, confrontos, desafios e práticas que anunciem novos tempos.

Este fato nos restou claro em diversos momentos da pesquisa, tornando indispensável ressaltar não ser possível compreender o desenvolvimento e implementação das políticas curriculares oficiais de modo "fechado", como se não ocorressem resistências e/ou subversões múltiplas ao longo de sua adoção. Do mesmo modo não podemos esquecer das diferentes abordagens e teorias acerca do currículo (como a teoria crítico-histórica e a libertária), questionadoras dos fundamentos e propósitos presentes nos documentos oficiais de ensino e que estimulam um engajamento crítico na análise por parte de professores e gestores escolares.

Neste sentido é preciso lançar luz sobre a contradição implícita no movimento de reprodução do capital que também está presente nas políticas curriculares oficiais. Em nossa pesquisa procuramos demonstrar como o homem tem uma espécie de uma "necessidade ontológica" na direção de humanizar-se e este ato é prejudicado pelas condições de conhecimento de si impostas pela marcha histórica curricular. Todavia, percebemos que o desenvolvimento desta necessidade ainda é possível, desde que a educação, como situação gnosiológica, em que o objeto cognoscível, em lugar de ser o término do ato cognoscente de um sujeito, seja o mediatizador de sujeitos cognoscentes favoreça a compreensão de si. Esta possibilidade está dada, é concreta, e nos diferentes períodos históricos analisados não se observaram estratégias políticas que a impedissem.

Portanto, como nos ensinou Freire (1987), é fundamental romper com o "pensar ingênuo", cuja meta é "agarrar-se a este espaço garantido, ajustando-se a ele e, negando a temporalidade, negar-se a si mesmo" (p. 53) e encorajar o "pensar crítico" sustentado pelo diálogo, uma vez que sem ele não há comunicação e sem esta não há verdadeira educação. A verdadeira educação, nos termos do grande educador brasileiro,

Não se faz de "A" para "B" ou de "A" sobre "B", mas de "A" com "B", mediatizados pelo mundo. Mundo que impressiona e desafia a uns e a outros, originando visões ou pontos de vista sobre ele. Visões impregnadas de anseios, de dúvidas, de esperanças ou desesperanças que implicam temas significativos, à base dos quais se constituirá o conteúdo programático da educação [ou seja, o currículo]". (Ibidem) 
Por fim, ao analisarmos esse período neoliberal, a despeito de toda seara teórica que a envolve, compreendemos melhor a afirmação de Marx de que o que importa é transformar o mundo, e não o interpretar. Neste sentido, a profissão que abraçamos significa um grande esforço nesta direção de combate às diferentes formas de "fetichismo", isto é, o compromisso docente impõe uma luta contra máscaras, disfarces e distorções de tudo o que ocorre ao nosso redor. Essência e aparência não são coincidentes e é este fato que revela a grande necessidade da ciência, caminho pelo qual podemos superar as aparências e dotar de sentido nossa ação no mundo, agir para o desvendamento das manifestações superficiais enganadoras que produzem resultados dramáticos. Decerto, a preocupação do capitalismo com a reprodução da mão de obra é um fato recorrente, verificado com o neoliberalismo implementado no Brasil, ou seja, um projeto político e econômico burguês que, em suma, mobilizou recursos financeiros nacionais e internacionais para a formação de uma classe trabalhadora qualificada e "respeitável".

Para encerrarmos esta última sessão faz-se necessário apresentarmos algumas considerações acerca do recente documento Base Nacional Comum Curricular (BNCC) e da Reforma do Ensino Médio (Lei No 13.415 aprovada em fevereiro de 2017 a partir da Medida Provisória No 746/2016). Ainda que este documento e a Reforma ainda sejam temas de diversas discussões, é relevante apontarmos ao menos algumas questões que nos parecem pertinentes. Em primeiro lugar, cabe frisar que a organização da BNCC estava prevista desde a Constituição de 1988 e pela LDB 9394/96, todavia sua discussão e tramitação contou com a força de grupos políticos e empresários que se esforçaram pelas reformas da educação básica e do ensino médio em favor dos anseios neoliberais.

A BNCC é um documento de caráter normativo que define o conjunto orgânico e progressivo de aprendizagens fundamentais que todos os alunos devem desenvolver ao longo das etapas e modalidades da educação e, mais uma vez, conforme definido pela LDB 9394/96, a Base deve nortear os currículos dos sistemas e redes de ensino das Unidades Federativas, como também as propostas pedagógicas de todas as escolas públicas e privadas de educação infantil, ensino fundamental e ensino médio.

Nessa perspectiva, o processo de implantação da BNCC e a aprovação da Reforma do Ensino Médio para reorganização curricular da Educação Básica 
parecem apontar não para o atendimento de seu público-alvo, mas para as demandas de mercado, que requerem trabalhadores flexíveis capazes de se adequarem às rápidas mudanças científico-tecnológicas que ditam o dinamismo do setor produtivo.

Diversos estudiosos criticam o discurso que defende a Reforma do Ensino Médio, por medida provisória, por suprimir o debate social e a manifestação democrática. Os principais argumentos governistas que justificaram o processo são nitidamente de caráter ideológico e viés neoliberal, apoiando-se, sobretudo, em três aspectos: a crítica ao chamado "currículo rígido" e, em consequência, a necessidade urgente de sua substituição por outro flexível, enxuto e dinâmico. Por fim, a proposição do estabelecimento de itinerários formativos diferenciados no Ensino Médio, de forma a valorizar a escolha dos estudantes para aquele itinerário que mais o atrair, concedendo-lhes o chamado "protagonismo juvenil".

Aliás, esse tem sido um dos slogans da campanha midiática que o governo tem veiculado para convencer os jovens de que a reforma atende aos seus interesses. Entretanto, apesar das propagandas evidenciarem a empolgação, a liberdade de escolha, numa proposta que só apresenta benefícios, não é retratado que a reforma não atende de fato às necessidades dos alunos, negando-lhes uma formação emancipatória, uma vez que a BNCC trará uma redução da carga horária, sendo complementada pelos itinerários formativos, que, possivelmente, compreenderão uma formação aligeirada e precarização, face às más condições físico-estruturais, aos recursos humanos e financeiros escassos, em que a grande parte das escolas públicas se encontra.

Neste sentido, e concluindo, gostaríamos apenas de endossar a preocupação de Walter Benjamin, anunciada por Michel Lowy (2005), acerca da luta até a morte entre opressores e oprimidos, exploradores e explorados, dominantes e dominados. Assim,

\footnotetext{
A história lhe parece uma sucessão de vitórias dos poderosos. O poder de uma classe dominante não resulta simplesmente de sua força econômica e política ou da distribuição da propriedade, ou da distribuição do sistema produtivo: pressupõe sempre um triunfo histórico no combate às classes subalternas. (p. 60)
} 
Entendemos ser exatamente o currículo escolar, em suas proposições ontológicas, que coloca a classe trabalhadora em pactuação com as classes dominantes, rebaixando suas demandas e perdendo contato com as lutas do passado, que poderiam conter fragmentos para uma experiência revolucionária. É por esta via analítica que entendemos a construção de um "conformismo", sustentado pelas concepções ideológicas do "trabalho" como uma mera atividade para o progresso social ou como ato político, perfazendo aquilo que Benjamin chama de "marxismo vulgar". Destarte, temos assistido mais recentemente um retrocesso acompanhado pelo progresso da técnica e pelo crescimento do poder das classes dominantes, resultando em grandes perdas para a classe trabalhadora.

Estas derrotas estão dadas, mesmo com a expansão de direitos, e não há meios para impedi-las, nem através de leis, uma vez que a expansão do capital ultrapassa hoje quaisquer barreiras formais. Como nos ensina Benjamin, "em cada época é preciso tentar arrancar a transmissão da tradição ao conformismo que está na iminência de subjugá-la" (p. 65), perspectiva que nos leva a acreditar que o “inimigo não tem cessado de vencer" (Ibidem). Portanto, é indubitável que a luta de classes também é uma disputa que se dá nos currículos escolares e é por lá que a Geografia também pode contribuir para a construção de uma outra sociedade. 


\section{Referências bibliográficas}

ALTHUSSER, Louis. Aparelhos Ideológicos do Estado: nota sobre os aparelhos ideológicos do Estado (AIE). Rio de Janeiro: Graal, 1983.

ALTHUSSER, Louis; BALIBAR, Étienne; \& ESTABLET, Roger. Ler o Capital. Rio de Janeiro: Zahar Editores. 1980.

ALVES, Ana R. C. O conceito de hegemonia: de Gramsci a Laclau e Mouffe. Lua Nova, São Paulo, nº 80, p. 71-96. 2010.

ALVES, Giovanni. Trabalho, corpo, subjetividade. Toyotismo e formas de precariedade no capitalismo global. Trabalho, Educação e Saúde, v. 3, n. 2, p.409428. 2005.

AMORIM, Henrique. Trabalho, classes sociais e luta política. In: Trabalho e Sociabilidade: perspectivas do capitalismo global. Bauru, SP: Canal6 editora, 2012, pp.105-117.

APPLE, Michael. Educação e poder. Porto: Porto Editora. 2001

Ideologia e Currículo. 3. Ed. Porto Alegre: Artmed. 2006

AREAS, James Bastos. A instauração ontológica no sofista de Platão: ontologia tradicional e modelos alternativos da filosofia grega. 1999. vi, $186 \mathrm{f}$. Tese (Doutorado) - Pontifícia Universidade Católica do Rio de Janeiro, Departamento de Filosofia. Disponível em: $\quad<$ http://www2.dbd.pucrio.br/pergamum/biblioteca/php/mostrateses.php?arqtese=1999-reas_J_B.pdf $>$.

Acesso em setembro de 2021.

ARISTÓTELES. Metafisica. Porto Alegre: Globo, 1969. 311p.

AUBENQUE, Pierre. El sentido del ser en El Sofista de Platón. Cuaderno Gris. Época II, 3: 3-15, 1990.

AZEVEDO, Fernando de. A transmissão da cultura. São Paulo: Melhoramentos; Brasília: INL, 1976. 268p.

BACHELARD, Gaston. A formação do espírito científico: Contribuição para uma psicanálise do conhecimento. Rio de Janeiro: Contraponto. 1996.

BARBOSA, Rui. Reforma do ensino primário e várias instituições complementares da educação pública. In: Obras Completas de Rui Barbosa. Vol. X, Tomo II. Rio de Janeiro: Ministério da Educação e Saúde, 1946.

BITETI, Mariane de Oliveira. Uma reflexão sobre o tema da ontologia em Geografia. 2007. Dissertação (Mestrado em Geografia) - Universidade Federal Fluminense, Departamento de Geografia. Niterói, RJ. 
BOBBIO, Norberto. O Conceito de sociedade civil. Rio de Janeiro: Edições Graal 1982.

BORNHEIM, Gerd. Dialética: teoria, práxis: ensaio para uma crítica da fundamentação ontológica da Dialética. 2. ed. Porto Alegre: Globo, 1983. vii, 340p.

BOURDIEU, Pierre; PASSERON, Jean-Claude. A reprodução: Elementos para uma teoria do sistema de ensino. Rio de Janeiro: Francisco Alves. 1982.

BRASIL. Parâmetros Curriculares Nacionais (PCNs). Ciências Humanas. Ensino Médio. Brasília: MEC, 2014.

CANDAU, Vera. \& MOREIRA, Antônio Flávio Barbosa. Currículo, Conhecimento e Cultura. In: Indagações sobre currículo. Ministério da Educação - SEB. 2006.

CARLOS, Ana F. A. A condição espacial. São Paulo: Contexto, 2015.

CARLOS, Ana F. A; Santos, César Simoni; ALVAREZ, Isabel Pinto (orgs.). Geografia Urbana Crítica: teoria e método. São Paulo: Contexto, 2018.

CARNEIRO LEÃO, Emmanuel. Filosofia Grega - Uma introdução. 1. ed. Teresópolis, RJ: Daimon, 2010. 275p.

CARVALHO, Delgado de. Methodologia do ensino geographico (introdução aos estudos de geographia moderna). Petrópolis: Vozes de Petrópolis. 1925.

CARVALHO, Laerte R. As reformas pombalinas da instrução pública. São Paulo: Saraiva. 1978.

CARVALHO, Maria. C. B. de. O conhecimento da vida cotidiana: base necessária à prática social. In: NETTO, José Paulo e CARVALHO, Maria do Carmo Brant de. Cotidiano, conhecimento e crítica. São Paulo: Cortez, 2015.

CASTORIADIS, Cornelius. A instituição imaginária da sociedade. 6. ed. Rio de Janeiro: Paz e Terra, 2007.

CAVALCANTI, Lana de S. A geografia escolar e a cidade: ensaios sobre o ensino de geografia para a vida urbana cotidiana. Campinas, SP: Papirus, 2012.

$\overline{\text { SP: Papirus, } 1998 .}$

Geografia, escola e construção de conhecimentos. Campinas,

CHAGAS, Valnir. Núcleo Comum para os Currículos do Ensino de $1^{\circ} \mathrm{e} 2^{\circ}$ Graus. Revista Brasileira Estudos Pedagógicos, Brasília, v.74, n. 177, p.385-423, maio/ago. 1993. 
CIAVATTA, Maria. O Conhecimento histórico e o problema teórico-metodológico das mediações. In: FRIGOTTO, Gaudêncio; CIAVATTA, Maria (org.). Teoria e Educação no labirinto do capital. São Paulo: Expressão Popular, 2014.

CONTI, José B. A Reforma do Ensino de 1971 e a Situação da Geografia. Boletim Paulista de Geografia, São Paulo, n. 51, p. 57-70, 1976.

CORNFORD, Francis M. La teoría platónica del conocimiento. Barcelona: 2007.

COSTA, Alexandre. Heráclito: fragmentos contextualizados. Rio de Janeiro: DIFEL, 2002.

COUTINHO, Carlos N. Gramsci: um estudo sobre seu pensamento político. Rio de Janeiro: Campus. 1992.

Expressão Popular. 2010.

O estruturalismo e a miséria da razão. 2. Ed. São Paulo:

CUNHA, Luiz A. A universidade temporã: o ensino superior, da colônia à Era Vargas [online]. 3rd ed. São Paulo: Editora UNESP, 2007.

DARDOT, Pierre; LAVAL, Christian. A nova razão do mundo: ensaio sobre a sociedade neoliberal. São Paulo: Boitempo, 2016.

DE CERTEAU, Michel. A invenção do cotidiano: artes do fazer. Petrópolis: Vozes, 3ed. 1998.

DELEUZE, Gilles; GUATTARI, Felix. Mil platôs: capitalismo e esquizofrenia. Rio de Janeiro: Editora 34, 1995.

DESCARTES, René. Meditações. Ebook Kindle. Sem datação.

DORE, Rosemary. Gramsci e o debate sobre escola pública no Brasil. Caderno Cedes, Campinas, Vol. 26, nº 70, p. 329-352. 2006.

DUAYER, Mario et. al. A ontologia de Lukács e a restauração da crítica ontológica em Marx. Florianópolis (SC). R. Katál. V. 16 n. 1 p. 17-25, 2012.

DUAYER, Mario. Crítica ontológica de Marx. In: NETTO, José P. (org). Curso livre Marx-Engels: a criação destruidora. 1. ed. São Paulo: Boitempo. 2015.

ENGUITA, Mariano Fernández. A face oculta da escola: educação e trabalho no capitalismo. Porto Alegre (RS): Artes Médicas, 1989.

FERREIRA, Alvaro. A Produção do espaço: entre dominação e apropriação. Um olhar sobre os movimentos sociais. Scripta Nova, Barcelona, no 245, 2007.

FEYERABEND, Paul. Contra o método. Rio de Janeiro: F. Alves, 1977. 
FLAKSMAN, Ana. Aspectos da recepção de Heráclito por Platão. 2009. 197 f. Tese (Doutorado em Filosofia) - Pontifícia Universidade Católica do Rio de Janeiro, Rio de Janeiro, 2009.

FOUCAULT, Michel. As palavras e as coisas: uma arqueologia das ciências humanas. 4a ed. São Paulo: Martins Fontes Paulista, 1987. 407p.

. Microfísica do Poder. São Paulo: Graal, 2007.

. Vigiar e Punir: Nascimento da Prisão. Rio de Janeiro: Vozes,

2004.

FREITAG, Bárbara. Escola, estado e sociedade. 4ed. São Paulo: Moraes. 1980.

FRESU, Gianni. Labriola, Gramsci e o materialismo histórico italiano. Revista Outubro, n 25, p. 84-102. 2016.

FREYRE, Gilberto. Casa-grande \& senzala: formação da família brasileira sob o regime da economia patriarcal. 50ed. São Paulo: Global. 2005.

FRIGOTTO, Gaudêncio. As novas e velhas faces da crise do capital e o labirinto dos referenciais teóricos. In: FRIGOTTO, Gaudêncio; CIAVATTA, Maria (org.). Teoria e Educação no labirinto do capital. São Paulo: Expressão Popular, 2014.

FURTADO, Celso. Formação econômica do Brasil. São Paulo: Editora Nacional. 2005.

GHIRALDELLI JR. Paulo. Introdução à educação escolar brasileira: História, política e filosofia da educação. Mimeo. 2001.

GOMES, Paulo Cesar da Costa. Geografia e modernidade. 1a ed. Rio de Janeiro: Bertrand Brasil, 1996. 366 p.

GONTIJO, Cláudio. A dialética do método da economia política na introdução aos Grundrisse. Econ. soc., Campinas, v. 25, n. 1, p. 209-246, abr. 2016.

GOODSON, Ivor F. Currículo: teoria e história. 10. ed. Petrópolis, RJ: Vozes, 2008.

GRAMSCI, Antonio. Cadernos do Cárcere. Volume 1: introdução ao estudo da filosofia, a filosofia de Benedetto Croce. 8. Ed. Rio de Janeiro: Civilização Brasileira. 2015.

Cadernos do Cárcere. Volume 2: os intelectuais, o princípio educativo, o jornalismo. 8. Ed. Rio de Janeiro: Civilização Brasileira: 2016.

Cadernos do Cárcere. Volume 3: Maquiavel, notas sobre o estado e a política. 8. Ed. Rio de Janeiro: Civilização Brasileira. 2017. 
Civilização Brasileira, 1982.

. Os intelectuais e a Organização da Cultura. Rio de Janeiro:

HABERMAS, Jürgen. O discurso filosófico da modernidade: doze lições. São Paulo: Martins Fontes Paulista, 2000. 540p.

HARPER, Babette et. al. Cuidado, Escola! Desigualdade, domesticação e algumas saídas. 24. Ed. Brasília: Editora Brasiliense. 1987.

HARVEY, David. 17 contradições e o fim do capitalismo. 1ed. São Paulo: Boitempo. 2016.

Condição pós-moderna: uma pesquisa sobre as origens da mudança cultural. $17^{\mathrm{a}}$. ed. São Paulo: Loyola, 2008. 349 p.

Teoria revolucionaria y contrarrevolucionaria en Geografía y el problema de la formación del ghetto. Cuadernos críticos de Geografía Humana. Barcelona. Ano 1 n. 4. Julho 1976.

HEGEL, Georg. W. F. Fenomelogia do espírito. Petrópolis (RJ): Vozes, 1992.

HEGEL, Georg. W. F.; MONDOLFO, R. Ciencia de la lógica. Spain, Europe: Hachette, 1968.

HEIDEGGER, Martin. A caminho da linguagem. 4a ed. Petrópolis, RJ: Vozes. 2008 .

Brasileiro, 1999.

Introdução à metafísica. 4a ed. Rio de Janeiro: Tempo . Ser e tempo. 3. ed. Petrópolis: Vozes, 1989.

HOBSBAWM, Eric J. A era das revoluções, 1789-1848. São Paulo: Paz e Terra. 2015.

HOLANDA, Sérgio B. Raízes do Brasil. 26 ed. São Paulo: Companhia das Letras. 1995.

HUBERMAN, Leo. História da riqueza do homem. Rio de Janeiro: Zahar, 1981.

IANNI, Octávio. O colapso do populismo no Brasil. 2ed. Rio de Janeiro: Civilização Brasileira. 1975.

KANT, Immanuel. A crítica da razão pura. Ebook Kindle.

Prolegómenos a toda metafísica futura. Lisboa: Edições 70, 1988.

KOSIK, Karel. Dialética do concreto. Rio de Janeiro: Paz e Terra, 1969. 
LANDER, Edgardo. "Ciências Sociais: saberes coloniais e eurocêntricos". In: LANDER, Edgardo (org.). A Colonialidade do Saber: eurocentrismo e ciências sociais. Perspectivas latino-americanas. Buenos Aires: CLACSO, 2005.

. "Marxismo, Eurocetrismo e Colonialismo". In: BORON, A.; AMADEO, J.; GONZÁLEZ, S. (orgs.). A Teoria Marxista Hoje: problemas e perspectivas. Buenos Aires: CLACSO, 2007.

LEAL, Vitor N. Coronelismo, enxada e voto. 7ed. São Paulo: Companhia das Letras. 2012.

LEFEBVRE, Henri. A noção de totalidade nas ciências sociais. mimeo. 31p. 1955.

. La presencia y la ausencia. Contribución a la teoria de las representaciones. México: FCE, 1981, p. 17-104.

Brasileira, 1991.

Lógica formal Lógica dialética. Rio de Janeiro: Civilização

. O espaço. In: Espaço e política. Belo Horizonte: UFMG, 2008.

LEONEL FRANCA, Pe. O método pedagógico dos Jesuítas - o "Ratio Studiorum". Rio de Janeiro: AGIR Editora. 1952.

LIMA, Elias Lopes de. Encruzilhadas geográficas: notas críticas sobre a compreensão do sujeito em geografia. 2013. Tese (Doutorado) - Universidade Federal Fluminense, Departamento de Geografia. Niterói, RJ.

- O sujeito da atividade prática. Encruzilhadas geográficas: notas sobre a compreensão do sujeito na teoria social crítica. Rio de Janeiro: Consequência, 2014. Capítulo 7, pp. 245-269.

LIMA, Walter Matias. A questão da metafísica e da subjetividade e sua crise na modernidade. SymposiuM. Recife (PE). Ano 3, p. 34 - 46. 1999.

LUCCI, Elian. Alabi. Território e Sociedade no mundo globalizado: geografia geral e do Brasil. São Paulo: Saraiva. 2010.

LUKÁCS, Georg. História e Consciência de Classe. São Paulo: Martins Fontes, 2003.

. Para uma ontologia do ser social I. São Paulo: Boitempo. 2012.

Para uma ontologia do ser social II. São Paulo: Boitempo.

2013.

MAGNOLI, Demétrio. Geografia para o Ensino Médio. São Paulo: Atual. 2008 
MARTINS, Marcus Vinícius Silva. O pensamento de Heráclito: uma aproximação com o pensamento de Parmênides. 2007. Tese (Doutorado) Universidade de Brasília, Departamento de Filosofia. Brasília, DF.

MARX, Karl. Contribuição à crítica da economia política. São Paulo: Expressão popular, 2008a

Crítica ao Programa de Gotha. São Paulo: Boitempo, 2012.

Grundrisse. São Paulo: Boitempo. 2011.

escolhidos. São Paulo: Abril Cultural, 1978.

Manuscritos econômicos-filosóficos e outros textos

. Manuscritos econômicos-filosóficos e outros textos escolhidos. São Paulo: Boitempo. 2008.

O Capital: crítica da economia política. Coleção Os Economistas. São Paulo: Abril Cultural, Livro 1, Tomo 1, 1983.

Cultural: Livro 1, Tomo 2,1996.

O Capital: crítica da economia política. São Paulo: Nova Teses sobre Feuerbach. Edições Kindle.

MARX, Karl., ENGELS, Friedrich. A ideologia alemã. São Paulo: Hucitec, 1984.

MASSEY, Doreen. Pelo espaço: uma nova política da espacialidade. Rio de Janeiro: Bertrand Brasil, 2008.

MERLEAU-PONTY, Maurice. Signos. Martins Fontes: São Paulo. 1991.

MÉSZÁROS, István. A educação para além do capital. São Paulo: Boitempo, 2008.

MORAES, Antônio Carlos R. Geografia, pequena história crítica. 20ed. São Paulo: Annablume. 2005.

MOREIRA, Ruy. Geografia e práxis: a presença do espaço na teoria e na prática geográficas. São Paulo: Contexto, 2012.

- Marxismo e Geografia (A geograficidade e o diálogo das ontologias). GEOgraphia. Ano 6. No 11. 2004.

Pensar e ser em geografia: ensaios de história, epistemologia e ontologia do espaço geográfico. São Paulo: Contexto, 2015.

A cabeça bem-feita: repensar a forma, reformar o pensamento.

Rio de Janeiro: Bertrand Brasil, 2001. 
MORIN, Edgar. Ciência com consciência. Rio de Janeiro: Bertrand Brasil, 2005.

MOUTINHO, Luiz Damon. Razão e Experiência: ensaios sobre Merleau Ponty. Rio de Janeiro: Editora UNESP, 2006.

NAGLE, Jorge. Educação e sociedade na primeira república. São Paulo: EPU/MEC. 1976.

NETTO, José P. Introdução ao método de Marx. São Paulo: Expressão Popular, 2011.

PEREIRA, Raquel Maria Fontes do Amaral. Da geografia que se ensina a gênese da geografia moderna. Santa Catarina: EdUFSC. 1999.

PILETTI, Claudino; PILETTI, Nelson. Filosofia e história da educação. 15. ed. São Paulo: Ática, 1995. 264 p.

PILETTI, Nelson. Evolução do currículo do curso secundário no Brasil. Revista Faculdade de Educação. 13 (2): p. 27-72. 1987.

PIMENTEL E SILVA, Christiane. O método em Marx: a determinação ontológica da realidade social. Serv. Soc. Soc., São Paulo, n. 134, p. 34-51, Apr. 2019.

PLATÃO. O Sofista. Ebook: Ebooks Brasil. 2003.

POGREBINSCHI, Thamy. O Enigma do político: Marx contra a política moderna. Rio de Janeiro: Civilização Brasileira. 2009.

PONCE, Aníbal. Educação e luta de classes. 19 ed. São Paulo: Cortez. 2001

POSTONE, Moishe. Tempo, trabalho e dominação social: uma reinterpretação da teoria crítica de Marx. 1. ed. São Paulo: Boitempo, 2014.

PRADO Jr. Caio. História Econômica do Brasil. 26 ed. São Paulo: Brasiliense. 2012

PRIGOGINE, Ilya. O fim das certezas: tempo, caos e as leis da natureza. 2.ed. São Paulo: Editora UNESP, 2011.

PRIGOGINE, Ilya; STENGERS, Isabelle. A nova aliança: a metamorfose da ciência. Brasília: Ed. Universidade de Brasília, 1984.

RACHID, Rodolfo José Rocha. A invenção platônica da dialética. 2008. Tese (Doutorado) - Universidade de São Paulo. Departamento de Filosofia, São Paulo.

RIBEIRO, Maria Luísa S. História da educação brasileira: a organização escolar. 12 ed. São Paulo: Saraiva. 1992. 
ROCHA, Genylton O. R. da. A trajetória da disciplina Geografia no currículo escolar brasileiro (1837 - 1942). 1996. Dissertação (Mestrado). Pontifícia Universidade de São Paulo. Departamento de Educação.

O Colégio Pedro II e a institucionalização da Geografia escolar no Brasil Império. Giramundo, Rio de Janeiro, V.1 n. 1, p. 15-34, Jan/Jun. 2014.

ROMANELLI, Otaíza O. História da educação no Brasil. 8ed. Petrópolis: Vozes. 1986.

SACRISTÁN, Jose Gimeno. A educação obrigatória: seu sentido educativo e social. Porto Alegre: ARTMED, 2001.

Alegre: Penso. 2020,

O currículo: uma reflexão sobre a prática. 3 . Ed. Porto

SANTOS, Leandro Assis. Linguagem como modo de Acontecimento de mundo: Um estudo a partir da Filosofia de Martin Heidegger. Lisboa: Novas Edições Academicas. 2016.

SANTOS, Maria Carolina Alves dos. A lição de Heráclito. Trans/Form/Ação. São Paulo. n. 13. p. 1 - 9. 1990.

SANTOS, Milton. A Natureza do Espaço: Técnica e Tempo, Razão e Emoção. São Paulo: Edusp, 2006.

SAVIANI, Dermeval. Escola e democracia: teorias da educação, curvatura da vara, onze teses sobre educação e política. 9. ed. São Paulo: Cortez Autores Associados, 1994. 96p.

Pedagogia histórico-crítica, quadragésimo ano: novas aproximações. Campinas (SP): Autores Associados. 2019.

Trabalho e educação: fundamentos ontológicos e históricos. Revista Brasileira de Educação, São Paulo, n. 34, v. 12, jan/abr. p. 152-165. 2007.

SECCO. Lincoln. Gramsci e a Revolução. São Paulo: Alameda, 2006.

SENNET, Richard. La autoridad. Madrid: Alianza Editorial. 1981.

SERRES, Michel. Ramos. Rio de Janeiro: Bertrand Brasil, 2008.

SEVERO, Martha Conceição. Teeteto: o logos como dialética. 1992. 109f. Dissertação (Mestrado)-Pontifícia Universidade Católica do Rio de Janeiro, Departamento de Filosofia, Disponível em: <http://www2.dbd.pucrio.br/pergamum/biblioteca/php/mostrateses.php?arqtese=1992Severo_M_C.pdf\& gt $>$. Acesso em setembro de 2021. 
SIBILIA, Paula. O homem pós-orgânico: a alquimia dos corpos e das almas à luz das tecnologias digitais. Rio de Janeiro: Contraponto, 2015, pp. 237-246.

SILVA, Andréa M. Geografia no ensino médio: práticas de avaliações em escolas estaduais de Juiz de Fora - MG. 2016. Dissertação (Mestrado) Universidade Federal de Juiz de Fora, Programa de Pós-Graduação em Educação.

SILVA, Tomaz T. da. Documentos de Identidade: Uma introdução as teorias do currículo. Belo Horizonte: Autêntica, 2005.

SODRÉ, Nelson W. Introdução à Geografia. 5ed. Petrópolis: Vozes. 1976.

SUERTEGARAY, Dirce M. A. Notas sobre a epistemologia da geografia. Cadernos de Geografia, UFSC, nº 12, pp. 1-63, 2005.

TATHAM, George. A Geografia no Século XIX. Boletim Geográfico. Rio de Janeiro, n. 150, ano XVII, 1960.

TERTULIAN, Nicolas. Sobre o método ontológico-genético em Filosofia. Perspectiva, Florianópolis (SC), v. 27, n. 2, p. 375-408, jul/dez. 2009.

THOMPSON, E. P. Tempo, disciplina de trabalho e capitalismo industrial. In: Costumes em comum: estudos sobre a cultura popular tradicional. São Paulo: Companhia das Letras, 1998.

VANEIGEM, Raoul. A arte de viver para as novas gerações. São Paulo: Conrad.

VASCONCELOS, Tiago S. As unidades de internação para menores infratores da cidade do Rio de Janeiro: Uma abordagem geográfica. 2007. 49p. Monografia - Pontifícia Universidade Católica do Rio de Janeiro, Rio de Janeiro, 2007.

Entre territórios do cárcere, de contenção e lugares de vida: uma microgeografia. 2010. Dissertação (Mestrado)-Pontifícia Universidade Católica do Rio de Janeiro, Departamento de Geografia.

VESENTINI, José William. Geografia Crítica e Ensino. In: OLIVEIRA, Ariovaldo U. (org.). Para onde vai o ensino de Geografia? 10ed. São Paulo: Contexto. 2012.

VIEIRA, Júlia L. A crítica de Marx à dialética hegeliana nos manuscritos econômico-filosóficos. ELEUTHERÍA, Campo Grande (MS), v. 2, n. 3, p. 9-22, dezembro/2017-maio 2018.

VLACH, Vânia R. F. O ensino de Geografia no Brasil: uma perspectiva histórica. In: VESENTINI, José W. (org.). O ensino de geografia no século XXI. Editora Papirus. Edições Kindle, sem datação.

WILLIAMS, Raymond. Base e superestrutura na teoria da cultura marxista. In: Cultura e materialismo. São Paulo: Editora UNESP. 2011. 
ŽIŽEK, Slavoj. A tinta vermelha: discurso de Žižek no Occupy Wall Street. Blog da Boitempo. 2012. Disponível em: $<$ https://blogdaboitempo.com.br/2011/10/11/a-tinta-vermelha-discurso-de-slavojzizek-aos-manifestantes-do-movimento-occupy-wall-street>. Acesso em setembro de 2021.

ZOTTI, Solange A. Sociedade, educação e currículo no Brasil: dos jesuítas aos anos 80. Quaestio - Revista de estudos de educação, Ano 4, n. 2, p. 65-81, 2002.

Sociedade, educação e currículo no Brasil: dos jesuítas aos anos 80. Campinas (SP): Autores Associados. 2004. 